\begin{abstract}
UNIVERSIDADE DE SÃO PAULO
FACULDADE DE FILOSOFIA, LETRAS E CIÊNCIAS HUMANAS

DEPARTAMENTO DE GEOGRAFIA

PROGRAMA DE PÓS-GRADUAÇÃO EM GEOGRAFIA HUMANA
\end{abstract}

\title{
A ORGANIZAÇÃO E INSERÇÃO DA PRODUÇÃO DE PEQUENAS UNIDADES AGRÍCOLAS NOS MERCADOS PAULISTANOS: \\ OS AGRICULTORES DO BAIRRO RURAL DE SANTO ÂNGELO
}

Antônio Carlos da Paz Santana

Tese apresentada ao Programa de PósGraduação em Geografia Humana, do Departamento de Geografia da Faculdade de Filosofia, Letras e Ciências Humanas.

Orientadora: Profa. Dra. Marta Inez Medeiros Marques

São Paulo 2006 
UNIVERSIDADE DE SÃO PAULO

FACULDADE DE FILOSOFIA, LETRAS E CIÊNCIAS HUMANAS

DEPARTAMENTO DE GEOGRAFIA

A ORGANIZAÇÃO E INSERÇÃO DA PRODUÇÃO DE PEQUENAS UNIDADES AGRÍCOLAS NOS MERCADOS PAULISTANOS:

OS AGRICULTORES DO BAIRRO RURAL DE SANTO ÂNGELO 


\section{DEDICATÓRIA}

Dedico este trabalho à memória de minha mãe, Dona Maria, e

aos meus filhos, Larissa e Pedro. 


\section{AGRADECIMENTOS}

Em particular ao WILSON, pelas explicações e esclarecimentos no conhecimento da realidade do bairro e do mercado do produtor, a quem devo muito; a sua esposa dona CIDA, que sempre disposta a ajudar, nos recebeu em sua residência sempre risonha; ao MÁRCIO, que nos deu as dicas sobre o funcionamento das CDRs; ao MENININHO, ao LOURENÇO, ao JOSIAS, ao DORACI e ao CICÉRO, pelas entrevistas concedidas; à ADRIANA e SILVANA, pelo trabalho que realizaram como agentes da pesquisa Demográfica e Sócio-Econômica, e a todos os agricultores que contribuíram para a realização deste trabalho;

Em especial, à Profa. MARTA INEZ MEDEIROS MARQUES, que com sabedoria, disposição e simpatia, tornou a minha caminhada mais frutífera, a quem serei eternamente grato;

Aos Prof ${ }^{\circ}$ s. Ariovaldo, Dieter, Wanderley e José Juliano (da FEA), que com os quais realizei cursos durante o Mestrado;

Às funcionárias da Secretaria da Pós-Graduação, pela gentileza do pronto atendimento;

Ao Dr. Zambotto, ao Takashi, ao Roberto, ao Sérgio (da CEAAP) e ao senhor Rafael Hirata, pelas entrevistas concedidas;

Aos amigos Cardoso e Valênia, pela ajuda na cessão de obras e revisão do texto, e aos colegas do grupo de estudo campo em movimento, pelas contribuições bibliográficas;

À Secretaria de Educação do Estado de São Paulo, pela ajuda financeira ao longo dos últimos anos desse trabalho:

Às diversas pessoas $e$ instituições que contribuíram de diferentes maneiras para a realização deste trabalho;

Aos familiares, amigos $e$ alunos pelo incentivo e conforto nos momentos difíceis desta jornada;

Em muito especial, à minha companheira Alexandra, que com afeto, apoio $e$ compreensão, tornou mais suave à realização deste trabalho. 


\section{RESUMO}

A partir do sistema agrícola, buscou-se compreender como os agricultores de pequenas unidades organizam sua produção e como ela é subordinada aos mercados. O estudo foi realizado no bairro rural de Santo Ângelo onde residem 284 famílias de posseiros produtores de hortaliças. Isso permitiu a compreensão da organização atual do mercado (CEAGESP, CEAAP, CDR, supermercados e outros) com relação à atuação dos agentes econômicos e aos mecanismos de monopólio do capital sobre a produção deste tipo de propriedade.

Partindo do pressuposto de que as pequenas unidades são frutos da contradição do modo de produção capitalista, sendo responsáveis por uma parte significativa da produção de alimentos frescos destinados aos grandes centros urbanos, chega-se à conclusão de que à subordinação aos mercados é a principal causa da ocorrência do processo de desintegração que este tipo de propriedade enfrenta. Apesar disso, os agricultores encontraram na organização política a maneira de permanecerem produzindo na localidade onde se encontram.

\section{ABSTRACT}

The agriculture development has relegated the cultivate of vegetables, in Brazil, to small familiar production units. The Mogi das Cruzes municipality is the highest producer in Metropolitan Region of São Paulo.

Almost all the production is destinated to São Paulo market, where it is comercialized in locals like CEAGESP or CEAAP. From these locals, the vegetables are distributed to other regions of São Paulo state or the country.

This study intend to discuss the organization of vegetables production and its comercialization in Metropolitan Region of São Paulo.

PALAVRAS-CHAVE/KEY WORDS

Diferenciação do Campesinato - Bairros Rurais - Cinturão Verde - Abastecimento e Distribuição - Organização do Mercado

\section{Peasant Differentiation - Country Neighborhood - Green-belt - Vegetable Suply - Market Organizition}




\section{SUMÁRIO}

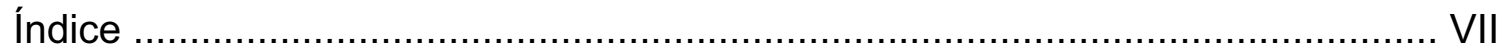

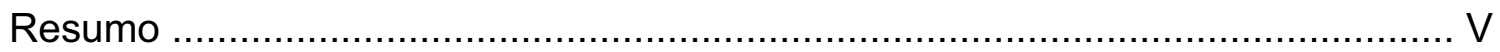

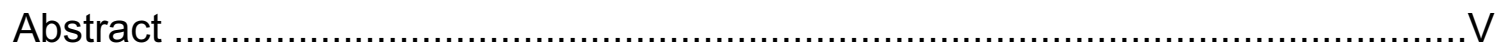

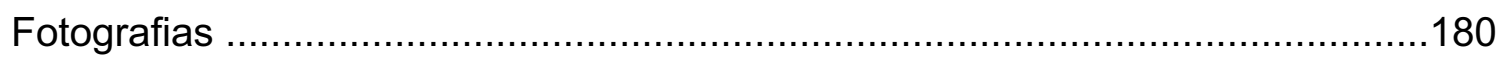

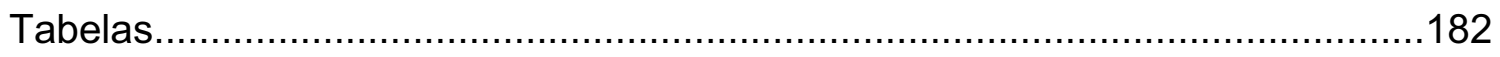

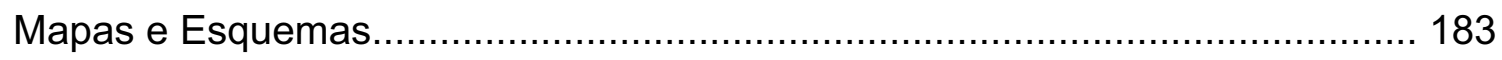

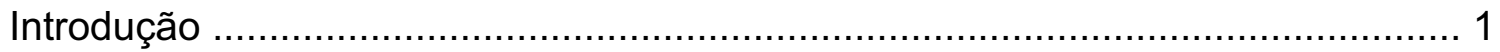

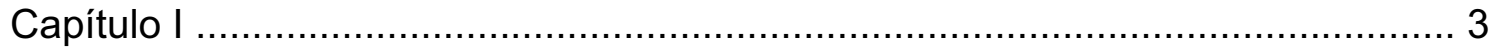

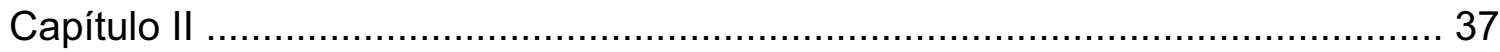

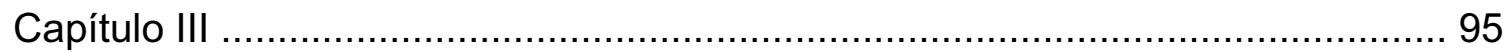

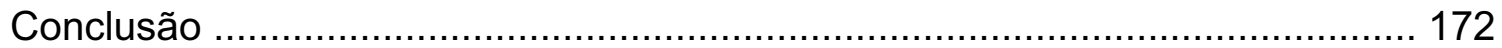

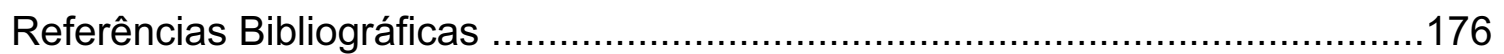




\section{ÍNDICE}

I. Introdução 1

II. Capítulo I: A Pequena Unidade e o Desenvolvimento da Agricultura sob a Perspectiva Marxista .................................................... 3

1 - A Obtenção da renda da Terra..................................................

2 - O Processo de diferenciação.................................................... 14

3 - O Processo de desintegração..................................................... 23

4 - O Processo de Recriação. ....................................................... 29

IV. Capítulo II: A Organização da Produção Camponesa em

Bairros Rurais

1- Conceituação de Bairro Rural ...................................................38

2 - Principais Elementos Constitutivos de Bairro Rural ...................43

3 - O Bairro Rural de Santo Ângelo ...............................................54

3.1 - O processo de ocupação............................................... 60

3.2 - A ameaça às áreas de proteção aos mananciais............... 65

3.3 - Descrição das áreas: títulos 1 e 2 ………………...........71

3.4 - As condições sociais e econômicas.................................... 75

3.5 - As relações sociais....................................................... 77

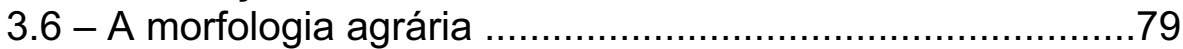

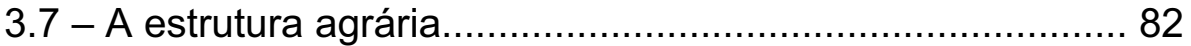

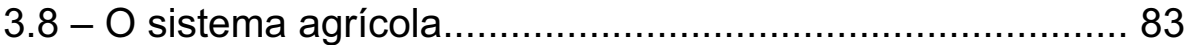

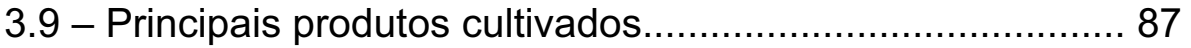

3.10 - Os elementos da produção................................................

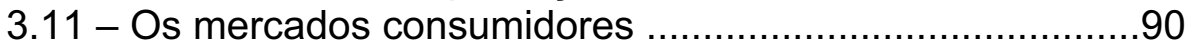

3.12 - A identidade social.................................................... 92

III. Capítulo III: A Organização do Mercado de Hortaliças da

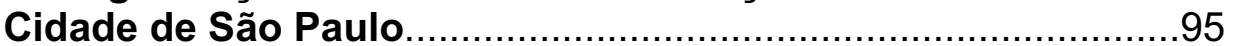

1 - A contribuição da agricultura de Mogi das Cruzes ......................96

2 - A contribuição das cooperativas ...........................................113

2.1 - O sistema de vendas.................................................. 120

2.2 - O sistema de compras.................................................. 125

2.3 - A importância das cooperativas para os centros urbanos...................................................................... 126

2.4 - O fim das cooperativas: causas prováveis...................... 128

3 - A Organização atual do mercado .........................................131

3.1 - Os aspectos históricos................................................ 133

3.2 - A atuação das centrais de abastecimento....................... 137

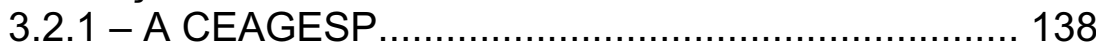

3.2.2 - A CEAAP ................................................. 144

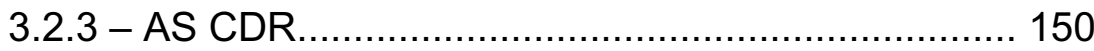

3.3 - As centrais varejistas................................................. 152 


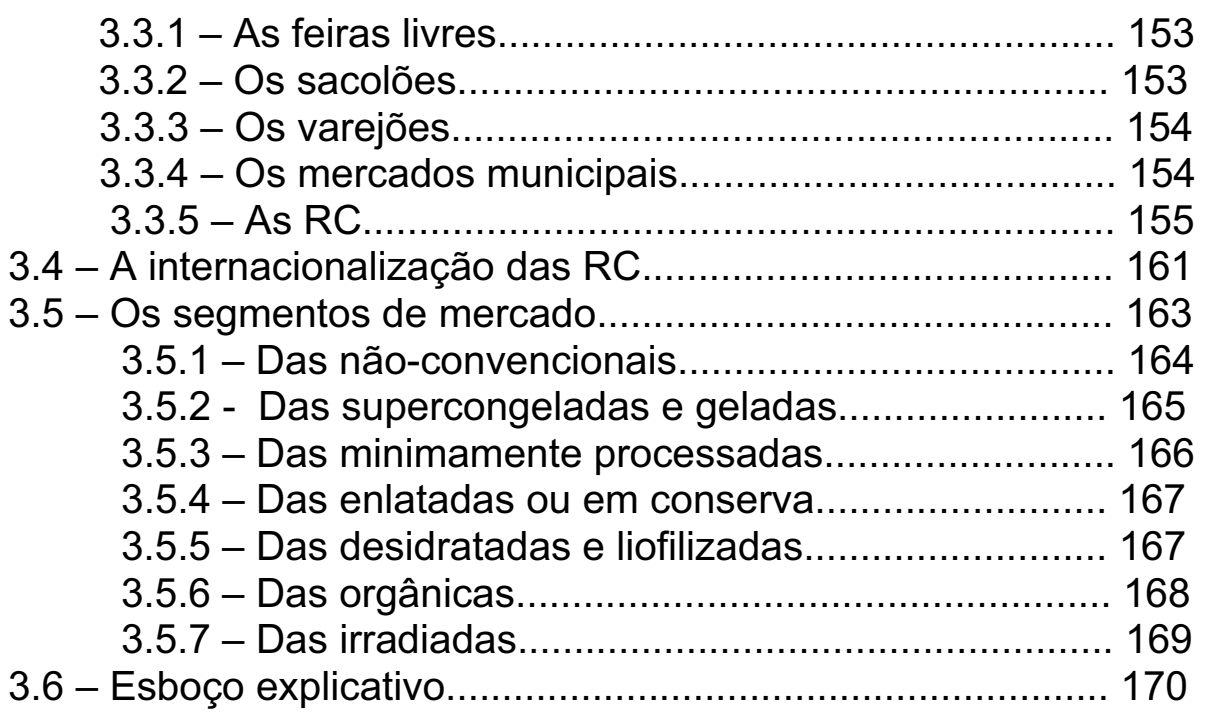

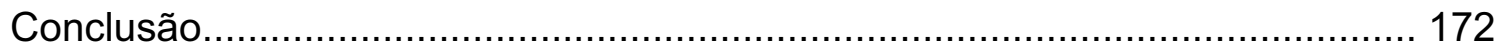

Referências Bibliográficas......................................................................... 176 


\section{I - INTRODUÇÃO}

O desenvolvimento da agricultura brasileira, cujas bases se assentam no modo de produção capitalista, relegou às pequenas unidades a produção dos alimentos básicos necessários aos trabalhadores do país.

O cultivo de hortaliças, que compõem parte da dieta de grande parte da população dos centros urbanos, encontrou nos municípios, que compõem a atual região metropolitana da Grande São Paulo, condições favoráveis ao seu desenvolvimento.

O município de Mogi das Cruzes é o centro de maior produção, em volumes, entre os municípios que compõem o cinturão verde desta região.

Os maiores volumes de alimentos frescos são destinados aos mercados paulistanos, onde só no CEAGESP, são comercializados cerca de $60 \%$, e daí são distribuídos para várias regiões do Estado de São Paulo e do país. Os demais $40 \%$ são comercializados por outros canais, como a CEAAP, que atende a pequenos comerciantes e a consumidores finais da capital, e pelas Distribuidoras Rurais, que atendem as redes de super e hipermercados da capital, da Grande São Paulo, das regiões do Vale do Paraíba, Baixada Santista e Litoral Norte Paulista.

Com a expansão da subordinação da produção à circulação, praticada pelos agentes econômicos que atuam no setor, os agricultores passaram a desenvolver diferentes modalidades (equipamentos) de inserção da produção nos mercados numa tentativa de amenizar os custos gerados por tal subordinação.

Isto decorre do fato de a atuação de tais agentes funcionar como catalisadora de informações sobre as novas formas de variedades dos alimentos, como as das hortaliças modificadas, processadas, enlatadas, desidratadas, etc., produzidos para atender segmentos específicos do conjunto de consumidores em função das novas demandas que se impõem com o crescimento das metrópoles. De posse de tais informações, eles desenvolvem diferentes mecanismos que subordinam a produção que cujos agricultores nem sempre têm acesso às informações sobre o mercado. 
O estudo sobre a organização da produção de hortaliças e de sua inserção nos mercados é fundamental para se compreender estas bases em que se estruturam as relações econômicas entre os agentes do mercado, consumidores e agricultores.

É sobre a compreensão de tais questões que este trabalho se propõe. Para tanto, realizamos um estudo, compreendido em três capítulos, sobre um dos bairros rurais do município de Mogi das Cruzes, o de Santo Ângelo, por reunir diferentes elementos que nos propiciaram a oportunidade de discutirmos a partir das contradições do modo de produção capitalista o desenvolvimento da agricultura brasileira, segundo a obtenção da renda fundiária, e os processos de diferenciação, desintegração e (re) criação do campesinato os quais foram sistematizados no capítulo I - A Pequena Propriedade Rural e o Desenvolvimento da Agricultura sob a Perspectiva Marxista. Já no capítulo II - $\underline{\text { A Organização da }}$ Produção Camponesa em Bairros Rurais -, discutimos a conceituação de bairro rural e a caracterização de seus elementos culturais a partir do bairro de Santo Ângelo e, no capítulo III - A Organização do Mercado de Hortaliças da Cidade de São Paulo -, analisamos como se organiza atualmente o mercado de hortaliças desta metrópole a partir da contribuição da produção dos agricultores de Mogi das Cruzes; da atuação das grandes cooperativas; das diferentes modalidades (equipamentos) de comercialização e das novas tendências do setor.

Esperamos com isso contribuir para o debate sobre as questões relacionadas à subordinação da produção ao mercado das pequenas propriedades rurais que se encontrem no interior de bairros rurais. 


\section{CAPÍTULO I - A PEQUENA PROPRIEDADE RURAL E O DESENVOLVIMENTO DA AGRICULTURA SOB A PERSPECTIVA MARXISTA}

Os primeiros estudos relacionados às pequenas unidades agrícolas, sob o modo de produção capitalista, foram realizados na Europa a partir do final do século XIX, e tiveram como finalidade a compreensão das transformações que a economia, de modo geral, vinha enfrentando em decorrência da expansão desse modo de produção na agricultura. Nessas teorias estão impressas as idéias e críticas de seus autores sobre as resoluções de problemas ligados à agricultura da época e suas concepções sobre como se daria o desenvolvimento futuro do modo de produção capitalista.

Muitos estudos da literatura clássica, apesar de terem sido elaborados há mais de um século, ainda se constituem num importante arcabouço teórico, em uso, em função do grande número de teorias elaboradas sobre diferentes problemas agrários do passado que ainda são verificáveis na agricultura atual do nosso país. Por isso, são as bases teóricas de muitos estudos realizados, na atualidade, em diferentes áreas do conhecimento como a economia, a política, a geografia, a história etc.

Os estudos de KARL MARX, elaborados no final do século XIX, a respeito da origem da renda fundiária capitalista, permanecem até hoje como a principal referência sobre este tema quando se deseja compreender as relações sociais que se desenvolvem na agricultura e as diferentes formas de extração da renda da terra. Eles estão sistematizados no capítulo XLVII - Gênese da Renda Fundiária Capitalista - do terceiro livro d'O Capital de KARL MARX, publicado em 1894. Nele, MARX desenvolveu sua teoria sobre a renda da terra tomando como referência de análise as pequenas propriedades rurais.

Ainda, nesse mesmo século, foram escritas duas outras importantes obras da literatura da Economia Política. São elas: A Questão Agrária de KARL KAUTSKY, publicada em 1898, e O Desenvolvimento do Capitalismo na Rússia de VLADIMIR ILITCH LÊNIN, publicada em 1899. 
Devido à densidade e abrangência de suas análises sobre a produção agrícola, estas obras se constituíram numa importante referência para os estudos que envolvem a pequena propriedade rural, a Questão Agrária, etc. Além de sua importância epistemológica, destaca-se ainda a contribuição que elas deram ao debate político-econômico com suas teorias sobre o destino social da pequena propriedade rural sob o modo de produção capitalista.

No Brasil, os debates atuais sobre os problemas agrários decorrem, sobretudo, da atuação dos movimentos sociais, em luta pela terra, que são constituídos por milhares de famílias de camponeses que foram expropriadas de pequenas unidades e que têm colocado a reforma agrária, e por extensão toda a questão agrária, no centro das discussões. Tais debates têm gerado muitas divergências ideológicas, ao nosso ver, com relação à adoção, à forma e ao método de uma possível reforma agrária e até mesmo, caso ela venha a ocorrer, sobre quais seriam seus beneficiários.

Enquanto para alguns autores a reforma agrária não é mais necessária, para outros, ela só teria sentido se a forma adotada tivesse como base o modelo das farmers. Entretanto, para outros, a reforma agrária é uma medida urgente e necessária para promover uma "revolução social" e ampliação das bases da cidadania, além de aumentar significativamente a produção de alimentos e a inclusão de milhares de trabalhadores no processo social produtivo.

Sendo assim, compreendemos que, dependendo da forma como a reforma agrária é pensada, ela poderia ter um grande efeito de criação de milhares, talvez de milhões, de novas pequenas unidades de produção familiar que passariam a desempenhar importante papel numa "nova" sociedade, tanto como grandes produtoras de alimentos quanto na inclusão de milhares de trabalhadores no processo social produtivo.

Para compreendermos como as pequenas unidades de produção familiar organizam a produção e como ela chega aos mercados consumidores, existentes na sociedade atual, partimos de um estudo de campo, realizado sobre 284 unidades de produção, todas localizadas em um dos bairros rurais do município de Mogi das Cruzes pertencente à Região Metropolitana de São Paulo. 
Para melhor organização das nossas análises, preferimos dividir esta primeira parte em quatro tópicos: no primeiro, analisamos a importância das formas de obtenção da renda fundiária para as pequenas unidades, segundo a teoria de MARX sobre as formas de obtenção da renda fundiária; no segundo, analisamos o desenvolvimento da agricultura, segundo as teorias da diferenciação e da desintegração e que como ele afetaria a existência das pequenas unidades de produção familiar; no terceiro, analisamos a teoria da recriação camponesa numa tentativa de compreendermos como se dá a reprodução das pequenas unidades; no quarto, analisamos os principais elementos da formação de bairros rurais e, finalmente, no quinto tópico, realizamos uma tentativa, através de dados históricos, de compreendermos como se formou a atual paisagem agrária da região de Mogi das Cruzes.

\section{1 - A obtenção da renda da terra}

MARX escreveu o capítulo XLVIII - Gênese Da Renda Fundiária Capitalista - constante no livro terceiro, na tentativa de esclarecer as dúvidas que havia sobre como se originava a renda fundiária pré-capitalista, e não com o intuito de compreender todas as características da pequena propriedade camponesa, a não ser aquelas sobre a renda fundiária.

A origem da renda fundiária capitalista é explicada, segundo MARX, a partir do excedente do lucro agrícola sobre o lucro médio, que o proprietário da terra obtém como forma de pagamento pela cessão de sua terra a algum produtor para cultivá-la. Ao adquirir a terra, o proprietário passa a ter o direito de monopólio sobre ela e, somente, vai explorá-la quando o valor dos preços de venda das mercadorias produzidas for superior aos custos de produção.

A teoria da renda da terra, elaborada por MARX, contém três formas de renda fundiária pré-capitalista (em trabalho, produtos e dinheiro), e duas formas de renda capitalista (a diferencial e a absoluta). 


\section{1 - A renda em trabalho}

Segundo MARX é a forma mais simples e antiga da renda fundiária. Ela se caracteriza por ser uma relação direta, e geralmente coercitiva, entre o produtor e o proprietário das terras. O produtor trabalha com os seus próprios meios de produção para si mesmo durante uma parte da semana, nas terras que lhe eram concedidas pelo proprietário. Mas, durante o resto da semana teria de trabalhar gratuitamente (coercitivamente) para o proprietário da terra.

O direito que o proprietário tem sobre o excedente da força de trabalho do produtor, advém da condição em que o produtor era apenas possuidor, ainda que de direito ou de fato, e não proprietário das terras, isso é a condicionante que dá direito ao proprietário de se apropriar de todo excedente de mão-de-obra do produtor.

\section{2 - A renda em produtos}

Origina-se quando o produtor reverte o pagamento em trabalho para o pagamento em produtos. Em nada difere da Renda em Trabalho, a não ser o fato de o proprietário não mais receber diretamente o pagamento do produtor na forma de mão-de-obra, mas na forma natural do produto em que ela se corporifica. $\mathrm{O}$ trabalho que o produtor realiza, para o proprietário, não se separa mais, nem no espaço e nem no tempo, do trabalho que realiza para si mesmo. Da mesma forma que a Renda em trabalho, a subordinação e a coação continuam juntas para garantir que o proprietário das terras continue a se apropriar do excedente de trabalho do produtor, mas, agora, não mais em trabalho e sim em produtos.

\section{3 - A renda em dinheiro}

Diferencia-se das demais formas apenas pela natureza, mas não pelo conteúdo. Nesta forma, o produtor em vez de entregar o produto ao proprietário da terra, paga-lhe o correspondente em dinheiro. Mas, do mesmo modo que a Renda em Trabalho e em Produtos, a subordinação e a sujeição continuam ocorrendo. Na qualidade de ser apenas produtor e não-proprietário, fosse por herança ou por tradição e coercitivamente, ele terá de fornecer ao proprietário da terra, seu 
senhorio, o trabalho excedente, sem contraprestação equivalente, na forma de produto excedente convertido em dinheiro.

A forma de renda em dinheiro é, ao mesmo tempo, a forma de dissolução das formas de renda anteriores, ao modo de produção capitalista, e a forma de renda responsável pela conversão da relação tradicional e consuetudinária entre o subordinado, que explora uma parte do solo, e o proprietário da terra numa relação contratual puramente monetária determinada pelas regras contratuais do capitalismo.

A forma renda-dinheiro é o último estágio evolutivo das formas de renda fundiária. Ela é responsável pela reversão da relação tradicional numa relação moderna baseada puramente no valor monetário e na relação de trabalho assalariado.

Assim, esta forma de renda, em que o possuidor do direito de explorar a terra passa a ser o arrendatário, revela o surgimento de uma nova relação de produção agrícola. Quando esta nova relação ocorre num mercado de elevado nível de desenvolvimento monetário e comercial, a terra passa a ser arrendada a capitalistas, que até então estavam fora do domínio rural. Eles introduzem na agricultura e para a zona rural capitais que até então só eram empregados na economia urbana.

Desse modo, entendemos que a agricultura passaria a ter a função de gerar apenas mercadorias e de ser, simplesmente, um meio de extorquir maisvalia.

Segundo MARX, esta forma só pode se generalizar nos países onde as economias já estão dominadas pelo mercado mundial. Isto é, se a economia já completou seu processo de consolidação capitalista. Em sua época, MARX verificou que as economias inglesa, russa e alemã já apontavam para este caminho (1980:905-917).

Com o surgimento da figura do arrendatário capitalista, entre o proprietário da terra e aqueles que efetivamente cultivavam a terra, as velhas e tradicionais relações de produção seriam substituídas por novas relações em que o arrendatário capitalista passaria a ser o explorador da mão-de-obra dos 
trabalhadores rurais e da mais-valia; enquanto o proprietário da terra passaria a ter com o arrendatário capitalista, simplesmente, uma relação puramente contratual e monetária.

A renda-dinheiro, como supôs MARX, "Pode ser considerada forma transitória entre a primitiva forma de renda e a capitalista, o sistema de parceria ou de repartição dos frutos da exploração no qual o agricultor (arrendatário) emprega, além de trabalho próprio ou alheio, parte do capital operante, e o proprietário fornece, além da terra, a outra parte desse capital (gado, por exemplo), sendo o produto dividido entre ambos em determinadas proporções que variam segundo os países". (1980: pág. 920).

No último tópico do Capítulo em referência, MARX desenvolveu os conceitos de renda relativa e de renda absoluta, com base de análise na pequena propriedade ou parcelaria. Esta forma de propriedade, que era dominante em sua época, foi o ponto de partida por ser ela uma forma em que o proprietário e o produtor eram uma só pessoa.

Nos países onde o modo de produção capitalista é pouco desenvolvido e onde a população rural é quantitativamente superior à urbana e a concentração de capitais seja limitada, é normal que a maior parte da produção agrícola se destine ao consumo do agricultor e de sua família, como meio de subsistência, e que apenas uma pequena parte, aquela que excede às necessidades da família, seja destinada ao mercado como forma de mercadoria, cuja renda obtida será revertida na aquisição de mercadorias não produzidas pelo grupo familiar.

\section{4 - A renda diferencial I}

Para MARX, independentemente do caráter da propriedade (se privada ou não) ou do modo de produção (se capitalista ou não), caso o excedente seja vendido por um valor de preço acima do preço médio do mercado, produzirá esse tipo específico de renda. A especificidade deste tipo de renda é explicada porque seu caráter está ligado unicamente à fertilidade do solo e à situação de localização da propriedade em relação aos mercados consumidores. 
Nos países onde existe o modo de produção capitalista, os preços são regulados de acordo com os valores dos piores solos. É a diferença entre os valores de preço de produção dos melhores e os dos piores solos que determina a renda diferencial. Do mesmo modo que também é determinada, pela diferença de valores de preço de produção entre os terrenos de melhor e os de pior situação (localização, estradas, etc.) em relação aos mercados consumidores.

\section{5 - A renda diferencial II}

Há, ainda, uma outra origem desta forma de renda. Ela é decorrente dos investimentos em capitais (benfeitorias, construções, melhoria do solo, etc.) que o arrendatário efetua nas terras em que cultiva, para melhorar a qualidade do solo e aumentar a produtividade, para minimizar os custo de produção.

Portanto, a renda diferencial I é obtida com a diferença de preço que se obtém em relação ao preço de produção com a venda da mercadoria produzida nos solos mais férteis e nos terrenos melhor situados; enquanto a renda diferencial II é decorrente unicamente dos investimentos de capitais realizados na unidade de produção.

No caso do produtor da pequena propriedade, que produz para sua subsistência, a renda da terra só será obtida se houver excedente de produção destinado ao mercado ou se houver investimentos de capitais na unidade de produção, mas, somente sobre aquela parte que se destina aos mercados. É somente sobre esta parte excedente, suplementar às necessidades do grupo familiar e resultante do excedente de mão-de-obra, que o agricultor pode extrair as formas de renda diferencial I e diferencial II.

Tanto na grande como na pequena propriedade, onde o proprietário da terra é o próprio agricultor, o capital gasto na compra da terra se constitui num dos elementos de custos de produção. Por ter sido comprada a terra constitui renda capitalizada, e por isso pode parecer que a renda tenha existência independente da qualidade do solo ou da situação de localização da unidade de produção, o que não é verdade. Pois cada vez que a terra é transferida para um novo proprietário nela se incorpora o capital que foi gasto por cada comprador. 


\section{6 - A renda absoluta}

Ao adquirir a terra, o proprietário passa a ter o direito de monopólio sobre ela e, somente, vai explorá-la quando o valor dos preços de venda das mercadorias produzidas for superior aos custos de produção Esta é a forma de renda denominada de absoluta.

Entretanto, para uma parte considerável dos agricultores proprietários ou não de pequenas unidades de produção, a terra não é cultivada segundo as normas ou padrões do modo de produção capitalista. Ao cultivar a terra, os agricultores estariam preocupados com as necessidades básicas de sua família e não em obter excedentes de rendas. Isso só ocorre em casos em que a produção excede às necessidades do grupo familiar ou quando, em função da posse de uma pequena propriedade, os agricultores se especializam na produção de uma determinada cultura que esteja voltada para atender a um determinado segmento do mercado consumidor.

A posse da terra é apenas a condição essencial para que o agricultor se aproprie do produto do seu trabalho e de sua própria família, seja livre e independente e responsável pelos meios de sua subsistência.

Não existem por parte da grande maioria dos agricultores camponeses das pequenas unidades de produção as normas de produção da sociedade moderna, porque nelas não se encontrariam “ $\{\ldots\}$ as condições materiais e espirituais da riqueza e do desenvolvimento da reprodução, e, em conseqüência, tampouco as condições de uma agricultura racional. Por outro lado, a grande propriedade fundiária reduz a população agrícola a um mínimo em decréscimo contínuo, opondo-lhe uma população industrial que aumenta sem cessar, concentrada em grandes cidades". (MARX, 1980, p. 931).

Tanto nesta forma de propriedade, quanto nas demais do modo de produção capitalista, o capital gasto na compra da terra, pode às vezes, constituir uma espécie de entrave ao progresso do estabelecimento. Sem capital para investir na produção, muitos proprietários teriam que recorrer a empréstimo e isto os colocaria numa situação de dependência econômica. 
A terra para os pequenos agricultores constitui o fundamento do trabalho; da autonomia e da independência econômica; além da obtenção dos meios de subsistência, da moradia e da reprodução dos laços familiares e não um negócio empresarial.

De certo modo, a constituição do valor dos preços das mercadorias, no sistema geral de preços, não é uma preocupação vital, embora seja costumeira, para os agricultores de pequena produção especializados em produtos muito perecíveis, pois, a venda do que já foi produzido será efetuada independentemente dos preços praticados. O valor do preço das mercadorias, que se destinam ao mercado, é simplesmente um valor referencial que é constituído levando-se em consideração, apenas, o valor dos custos da produção sem incluir o valor da mão-de-obra do grupo familiar. O cálculo da renda camponesa se dá em outras bases, mas o preço do produto é um fator importante apenas para se determinar este tipo de renda.

Os agricultores do Bairro de Santo Ângelo compreendem que a terra é um bem natural e divino, que foi dado aos homens para que nela se produza as necessidades de quem nela trabalha. $O$ fato de destinarem toda produção para os mercados, sem que isto seja o excedente das necessidades do grupo familiar, se explica mais pela necessidade de se obter as condições de vida do grupo familiar que pelo tamanho da propriedade; das condições naturais existentes e da elevada demanda que a proximidade aos grandes centros urbanos proporcionam.

Desse modo, uma parte da produção destes agricultores é dada gratuitamente à sociedade e não contribui para a formação geral de preços. $A$ isto, MARX se refere afirmando que "parte do trabalho excedente dos camponeses que lidam nas condições mais desfavoráveis é dada de graça à sociedade e não contribui para regular os preços de produção, nem para formar o valor em geral. Esse preço mais baixo, portanto resulta da pobreza dos produtores e não da produtividade do trabalho". (MARX, 1980, pág. 923/4).

Durante o período em que foi realizado o estudo, não foi verificada nenhuma forma de obtenção de renda fundiária pré-capitalista entre os agricultores do Bairro de Santo Ângelo. 
Quanto às formas de renda capitalista, ocorre a obtenção da renda diferencial I, que é realizada mediante a existência de solos férteis, em áreas baixas do bairro, onde estão às várzeas do rio Jundiaí. Embora ali haja problema com relação aos períodos de cheias, em que uma parte das terras ficam submersas sem poder ser exploradas, este é efetivamente um problema ao qual os agricultores souberam se adaptar. Se, por um lado, as constantes cheias, que se verificam durante as estações chuvosas, primavera e verão, acarretam uma redução significativa no uso dos solos nestas estações pelo alagamento de algumas unidades de produção, por outro, são elas as principais transportadoras do material orgânico que será depositado, nas várzeas, e que irá formar a camada sedimentar responsável pela fertilidade dos solos.

Nas áreas de encostas, onde este problema não afeta diretamente, o que se verifica durante a ocorrência das cheias é um aumento significativo da umidade do solo nestas áreas; enquanto que durante as estações secas, outono e inverno, ela se reduz significativamente necessitando de irrigação diariamente.

Os agricultores mais capitalizados, diante deste problema, passaram a adquirir a posse de unidades em área de várzeas e de encosta, numa tentativa de manter a produção durante as estações secas e chuvosas. Assim, a renda diferencial I é obtida por estes agricultores tanto nas áreas de várzeas quanto nas de encostas.

Quanto à renda diferencial II, ela também é obtida, porém de forma mais ampla entre os agricultores que têm unidades de produção de áreas maiores, cujo volume de produção pode oferecer uma maior capitalização, por um lado, e um maior nível de investimentos, por outro. Esta situação foi verificada mais claramente entre os agricultores sulistas, os quais começam a apresentar uma pequena diferenciação econômica se comparada aos nordestinos, pois possuem melhores condições de produção e de transportes como por exemplo maiores áreas; caminhões; trator; mini-tratores e sistema de irrigação mais modernos e aparelhados; galpão de alvenaria para depósito e lavagem das mercadorias; etc.

Entre os agricultores de menor condição econômica a obtenção da renda diferencial II é proporcionalmente inferior. Os poucos investimentos realizados em 
construção, que geralmente é improvisada, se explicam pela ausência ou mínima capacidade de capitalização, em decorrência das baixas condições de produção e transportes, e pela incerteza da permanência no lugar decorrente do fato das terras serem ocupadas mediante a posse. Diante destas situações, os agricultores preferem não realizar construções permanentes preferindo o tipo de construção improvisada de baixo custo pois caso venham a perder a posse das terras, isto não significaria prejuízos muitos significativos para as famílias.

A localização das unidades junto aos mercados dos grandes centros urbanos da região metropolitana de São Paulo, Vale do Paraíba e Baixada Santista, cuja existência de boas estradas favorecem o escoamento da produção, pode proporcionar aos agricultores a obtenção da renda diferencial. Mas, há muitos agricultores que não possuem veículos próprios para transportar sua produção até os centros consumidores. Para estes agricultores a única alternativa é a venda da produção aos atravessadores na porta da chácara, o que acarreta a perda da obtenção da renda diferencial, uma vez que ela é transmitida para o comerciante atravessador.

De modo mais geral, o que se percebe é que todos os agricultores estão de alguma forma subordinados ao mercado, alguns mais e outros menos, tanto na produção quanto na comercialização ou na distribuição, e é em função disso que se há obtenção de renda por parte dos agricultores ela certamente tem sido transmitida para os agentes atravessadores que atuam no mercado.

Assim, compreendemos que a contribuição de MARX para os estudos da pequena propriedade extrapola a teoria da renda da terra para alcançar os limites da crítica à propriedade privada e que foi evidenciada em suas próprias palavras: “(...) em ambas as formas, em vez de se cultivar consciente e racionalmente a terra, como propriedade perpétua e coletiva, condição inalienável da existência e da reprodução das gerações que se sucedem, o que existe é a exploração que desperdiça as forças do solo e, além disso, essa exploração não depende do nível atingido pelo desenvolvimento social, e sim das condições fortuitas e variáveis dos produtores particulares. Isso acontece com a pequena propriedade, por carência de meios e de conhecimentos científicos para aplicar a produtividade social do 
trabalho; com a grande propriedade, em virtude de a exploração desses meios se destinar ao enriquecimento mais rápido possível do arrendatário e do proprietário; e com ambas, por dependerem do preço de mercado". (MARX, 1980, pág. 930).

\section{2 - O Processo de Diferenciação}

Além da contribuição de MARX sobre a renda fundiária, utilizamos, também, os estudos de dois autores marxistas sobre o desenvolvimento da agricultura sob o modo de produção capitalista e os processos de diferenciação e de desintegração das pequenas unidades.

Apoiaremos nossas referências nestas teorias, mas conscientes de que o objetivo é o de construir uma discussão onde as teorias e os conceitos sejam testados e (re) elaborados a partir do confrontamento com uma nova realidade, a qual foi atingida com o nosso olhar em um determinado lugar e tempo, a fim de que o conhecimento possa ser (re) examinado e construído permanentemente de acordo com as diferentes realidades.

Os estudos aos quais lançamos mão, são considerados como os clássicos da literatura sobre a pequena propriedade vista sob o modo de produção capitalista e têm o enfoque voltado para a compreensão de como se comportam as pequenas, médias e grandes propriedades em vista do desenvolvimento capitalista na agricultura. Tais estudos são contemporâneos e foram escritos no momento em que se dava o desenvolvimento do capitalismo na agricultura européia. Lançamos mão, portanto, das seguintes obras: A Questão Agrária de KARL KAUTSKY, publicado em 1898, e o capítulo II, A Desintegração do Campesinato, d'O Desenvolvimento do Capitalismo na Rússia de VLADIMIR ILITCH LÊNIN, publicado em 1899.

As transformações que a agricultura européia vinha apresentando nas últimas décadas do século XVIII, em função da expansão do capitalismo, revelaram processos contraditórios que suscitaram muitas dúvidas e controvérsias entre os teóricos defensores da economia populista e os marxistas. Coube a estes últimos a tarefa de lançar mão de teorias já concebidas sobre o desenvolvimento 
do capitalismo numa tentativa de se vislumbrar qual seria o futuro da agricultura e particularmente dos pequenos camponeses em decorrência do aparecimento de novos processos que já se verificava na agricultura.

Na Alemanha e na Rússia os debates se desenvolveram, dentre outras questões, em torno da luta dos pequenos camponeses contra a grande propriedade e o seu desdobramento frente ao processo revolucionário que se supunha iminente e o processo de desintegração e proletarização dos camponeses pobres e de fortalecimento e enriquecimento dos camponeses ricos.

KAUTSKY entendia que o modo de produção capitalista já era dominante na sociedade européia e o que movia aquele século e dava fisionomia à sociedade era o processo de antagonismo entre a classe dos capitalistas e a do proletariado assalariado. Como marxista, compreendia que todo processo de desenvolvimento do modo de produção capitalista redundaria na universalização proletária. Ele compreendia que o ponto de partida deste processo teria sido a dissolução que a indústria moderna e o comércio determinavam na pequena indústria doméstica dos camponeses. (1898: p. 22 e 26).

LÊNIN compartilhava da mesma opinião, mas compreendia que a principal preocupação devia ser o estudo da formação do mercado consumidor interno porque sua base seria formada pela desintegração do antigo campesinato. (1985: pág. 35).

Enquanto os estudos de KAUTSKY foram mais abrangentes, incluindo inclusive dados sobre a agricultura alemã, francesa, americana, britânica, australiana, etc., LÊNIN fora mais específico, preferindo analisar estatísticas sobre os dados agrícolas dos zemstvos ${ }^{1}$ das províncias russas.

A preocupação que tinha KAUTSKY, ao realizar o seu estudo, era decorrente das discussões que se travaram em torno do programa agrário elaborado em virtude das deliberações do Partido Social-Democrático alemão no

\footnotetext{
${ }^{1}$ Os zemsvtos eram instituições de auto-administração local nas províncias centrais da Rússia que eram controlados pelos governadores e pelo ministério do Interior. Foram criadas em 1864 e tinham a competência de realizarem pesquisas e estatísticas sobre a organização de hospitais, construção de estradas, seguros. (Lênin, 1985, p. 35).
} 
congresso de Frankfurt e condenado no congresso de Breslau. Elas evidenciaram que na Social-Democracia alemã, como na Social-Democracia internacional, existiam diferentes opiniões sobre as tendências da evolução da agricultura, se no futuro prevaleceria a pequena ou a grande propriedade, originando, por conseguinte, um impasse sobre a política agrária que o Partido da SocialDemocracia alemão deveria adotar, sendo necessário, para tanto, um estudo sobre a situação agrária vigente. (idem: pág. 15).

KAUTSKY entendia que o modo de produção capitalista já era dominante e o que estava faltando para se compreender as transformações que vinham ocorrendo na agricultura era uma teoria que permitisse seguir um rumo certo em meio a tantas transformações. Faltava, como bem disse, o "conhecimento das tendências fundamentais que vinham determinando o processo revolucionário de transformação da agricultura". (Ibidem: pág. 16).

Apesar das críticas que tinha em relação à obra O Capital por considerála incompleta e compreender que Marx só tinha se ocupado com a agricultura capitalista, embora considerasse que o capítulo sobre a da Renda Territorial do livro três era a exceção, KAUTSKY analisou as características da agricultura alemã a partir das teorias marxistas do valor, da mais-valia e lucro e da renda da terra.

Engels, e, sobretudo Marx, disseram, com efeito, coisas muito importantes sobre fatos de ordem agrária, mas em regra geral só o fizeram em observações acidentais ou em curtos artigos. Abriremos uma exceção para a parte da Renda territorial no terceiro volume de O Capital, mas ela não foi inteiramente concluída. Marx morreu sem ter terminado a sua obra fundamental. (Ibidem: pág. 17).

As teorias gerais d'O Capital estudadas por KAUTSKY, talvez exaustivamente, a ponto de LÊNIN afirmar que ele conhecia Marx de $\operatorname{cor}^{2}$, fizeram-no perceber que a agricultura moderna se baseava fundamentalmente na propriedade privada da terra e no caráter de mercadoria que todos os produtos agrícolas apresentavam. Daí ser necessário, recorrer as teorias descritas por Karl

\footnotetext{
${ }^{2}$ Esta afirmação foi citada por Moniz Bandeira, ao fazer a apresentação da A Questão Agrária, publicada pela Editora Laemmert em 1968.
} 
Marx n'O Capital, não somente para se compreender o desenvolvimento do capitalismo e, particularmente, da agricultura no modo de produção capitalista, mas, sobretudo, para compreendê-la a partir de uma teoria que integrasse todos os seus fenômenos dando-Ihes uma direção que apontasse uma tendência.

E O Capital, segundo ele, se revestia de "interesse inapreciável para o nosso conhecimento dos fatos de ordem agrária, inapreciável não apenas pelos seus resultados, mas, sobretudo pelo seu método, que nos habilita a prosseguirmos de maneira proveitosa além dos seus domínios". (Ibidem: p. 17).

Se, por um lado, o modo de produção capitalista já era dominante na época de KAUTSKY e LÊNIN, por outro, não era a única forma de produção existente. $\mathrm{Na}$ agricultura alemã, por exemplo, ainda se encontravam modos de produção pré-capitalistas que se mantiveram ao longo dos tempos.

Sendo assim, para KAUTSKY, o papel do teórico deveria ser o de separar o modo de produção capitalista, na sua essência, das demais formas que não fossem capitalistas. Só assim, seria possível compreender as transformações. Para ele esta constatação era importante, já que compreendia que os partidos democráticos e revolucionários não conseguiam perceber a diferença e muito menos estabelecer uma separação entre estes modos de produção.

Para estes partidos os camponeses constituíam a classe intermediária e a mais numerosa da sociedade e, historicamente, sempre foi uma classe de luta, isto é, contrária à igreja, aos príncipes e até mesmo contra a nobreza. Isso de certo modo preocupava os partidos porque num processo revolucionário, tido como iminente, os camponeses poderiam ser contra-revolucionários.

Os partidos acreditavam que os camponeses eram tradicionais, antidemocráticos $\mathrm{e}$ individualistas. $\mathrm{E}$, por isso mesmo, os trabalhadores assalariados urbanos não podiam contar com eles num eventual processo revolucionário. Eles viam o camponês como um ser misterioso, estranho e inquietante para a sociedade, disse KAUTSKY. (Ibidem, pág. 22).

KAUTSKY afirmou que a Social-Democracia, no começo, pouco teria se preocupado com os camponeses, por exemplo. Isso era devido ao fato de que ela não era um partido verdadeiramente burguês no sentido da palavra. Era um 
partido de luta de classes que esperava que a evolução econômica lhe preparasse o caminho para a revolução, tanto na cidade quanto no campo. E, particularmente, entendia que o futuro da agricultura pertenceria à pequena propriedade e não a à propriedade capitalista.

A Social-Democracia, no começo, pouco se preocupou com o camponês. Isto se explica por não ser ela um partido democrático no sentido burguês da palavra, uma benfeitora de todo o mundo, visando a satisfazer os interesses de todas as classes, por mais oposta que sejam umas das outras. Ela é um partido de luta de classe. A organização do proletariado urbano reclamou, nos primeiros anos de sua existência, todos os cuidados. E ela esperava que a evolução econômica the preparasse o caminho no campo como na cidade, e que a luta entre a pequena e a grande exploração conduzisse à supressão da primeira, de maneira que the fosse então fácil tarefa a conquista, ainda como partido puramente proletário, da massa da população agrícola. (KAUTSKY, 1985, pág. 22).

Em meio a esta discussão política KAUTSKY desenvolve a sua teoria sobre a diferenciação econômica. Sua principal preocupação não era a de saber qual das formas de propriedade, se a grande ou a pequena, seria mais vantajosa para o processo revolucionário. Para ele já estava bastante claro que esta era uma questão que já preocupava os economistas havia mais de um século e que ainda não se vislumbrava o seu fim.

Vejamos o que ele afirmou, dois anos depois, no Prefácio da Edição francesa: "Antes de empreender as pesquisas sobre a questão agrária, cujos resultados constam deste volume, a minha concepção da evolução social era que a exploração camponesa se via ameaçada de um lado pela fragmentação, de outro, pela grande empresa. Portanto, o mesmo desenvolvimento, embora talvez sob forma diversa, se produzia na agricultura e na indústria - a proletarização num dos pólos, no outro a marcha avante da grande exploração capitalista". (Ibidem, pág. 12).

Todavia, KAUTSKY compreendia que o debate não deveria se fixar na oposição entre a grande e a pequena propriedade, como compreendia a economia burguesa. E nem simplesmente procurar os elementos da revolução nos 
mecanismos de agiotagem e endividamento, pelos quais os camponeses eram desterritorializados, como pensavam os socialistas.

Compreendia também que a economia burguesa atribuía um caráter conservador demais aos camponeses, porque, segundo ela, a relação de superfície entre os proprietários pouco tinha se modificado. Mas, também, sustentava que somente o endividamento dos camponeses não era suficiente para se compreender todas as transformações que ocorriam na agricultura. $O$ endividamento dos camponeses era um fenômeno anterior ao modo de produção capitalista e, portanto, "não constituiria a mola de uma evolução que desembocasse num modo de produção mais elevado". (Ibidem: pág. 314).

O desenvolvimento do modo de produção capitalista, segundo KAUTSKY entendia, acirraria a luta entre a grande e a pequena propriedade pela conquista de mais terras, ocasionando uma corrida ao crédito. $O$ acesso ao crédito, por sua vez, possibilitaria ao produtor atingir as vantagens da produção em larga escala. $\mathrm{E}$ o aumento da produção aumentaria consideravelmente a força da ação do capital na agricultura e, conseqüentemente, apressaria o progresso econômico.

Mas, isso se aplicaria mais na indústria que na agricultura. Como o endividamento da propriedade territorial, naquela época, era restrito apenas a certas conveniências de expansão sem, contudo, alterar as relações de propriedade, desse modo, não se poderia considerar o endividamento como um elemento de avanço para um modo de produção mais moderno.

Nem mesmo o aumento da população rural, que criou a necessidade de aumentar o número de parcelas de cultivo e da construção de mais moradias, que conduziu o capital usurário a promover leilões de terras e o retalhamento das propriedades individuais, considerada por KAUTSKY como uma das alavancas da expropriação, constituiu a força propulsora, isto é, a tal da mola da evolução econômica que redundaria no modo da produção capitalista.

Então, para KAUTSTKY, o que constituiria o fator de desenvolvimento era a indústria "a indústria constitui a mola não apenas da sua própria evolução, mas ainda da evolução agrícola". Portanto, seria a indústria (a mola) e não a agricultura o fator do desenvolvimento geral da sociedade. "Vimos que foi a manufatura 
urbana que dissociou, no campo, a indústria e a agricultura, que fez do rural um lavrador puro, um produtor dependente dos caprichos do mercado, que criou a possibilidade de sua proletarização". (ibidem, pág. 317).

Mas, quais diferenças existiam entre a grande e a pequena propriedade em que KAUTSKY se baseava para sustentar seus argumentos sobre a diferenciação econômica? Que conseqüências econômicas e sociais estas diferenças apontavam?

KAUTSKY considerou que a diferença entre a grande e a pequena propriedade se manifestava no tamanho da propriedade; na quantidade de cômodos e de bens móveis existentes na casa de moradia e de suas dependências; na quantidade de animais de ferramentas; de máquinas e de trabalhadores assalariados. A superioridade técnica (racional e científica) da grande propriedade, o excesso de trabalho familiar e insuficiência de consumo na pequena propriedade e as vantagens do acesso ao crédito constituiria o diferencial entre a grande e a pequena propriedade.

Consideremos uma grande propriedade, com superfície igual à de cinqüenta pequenas parcelas camponesas, e comparemos: de um lado, teremos uma única cozinha com um fogão; de outro, cinqüenta cozinhas com cinqüenta fogões. De um lado talvez cinco, de outro cinqüenta cozinheiras. De um lado talvez cinco quartos aquecidos no inverno, com cinco lampiões; de outro, cinqüenta. De um lado, querosene, café de chicória, margarina adquiridos por atacado; de outro, tudo comprado ao varejo, etc. Se sairmos da casa para penetrarmos no pátio, encontraremos na grande exploração um estábulo para cinqüenta a cem vacas, ao passo que os pequenos camponeses possuem, somados, cinqüenta estábulos para uma ou duas vacas de cada um. Cada um deles tem uma granja, uma nascente ao invés de cinqüenta. (KAUTSKY, 1968, pág.109).

Podemos, portanto, a partir do que KAUTSKY escreveu, extrair os seguintes pontos como conseqüências fundamentais para a agricultura segundo a evolução do desenvolvimento econômico, entendido por ele mesmo:

I - ocorreria uma diferenciação qualitativa entre a pequena e a grande propriedade - isto é, a primeira se voltaria para as necessidades essenciais 
familiares; enquanto a segunda se organizaria essencialmente para atender às necessidades do mercado, mas, as duas de modo diverso, estariam submetidas à indústria;

II - as pequenas propriedades se tornariam subordinadas - as pequenas propriedades seriam forçadas a vender parte de sua força de trabalho, sob a forma de assalariamento, ou a produzir manufaturas domésticas devido à necessidade de dinheiro. Isto as colocariam numa situação de dependência econômica, subordinação, em relação à indústria e aos mercados urbanos de mão-de-obra e de consumo e insumos;

III - as grandes propriedades dependeriam tecnologicamente das indústrias - estas propriedades, essencialmente produtoras de mercadorias, seriam forçadas a procurar nas indústrias e nos centros urbanos outras fontes de investimentos para a manutenção do lucro;

Em tese, o uso da tecnologia, por exemplo, tende à redução de custos, mas, entretanto, esta tendência na agricultura sob o modo de produção capitalista não se faz sem, contudo, enfrentar forças contrárias como, aliás, é norma geral deste tipo de economia. Os pesados encargos de produção decorrentes do aumento da renda territorial em função do aumento de arrendamentos; de empréstimos financeiros; de mão-de-obra; de melhoria dos solos, etc., conjugados entre si, apesar do desenvolvimento tecnológico, elevam cada vez mais os custos de produção.

KAUTSKY considera a influência da escala tecnológica nos resultados econômicos da produção, mas nós, entendemos que nem sempre o uso intenso de novas técnicas é positivo para os agricultores de pequenas unidades. Neste tipo de propriedade, além de nem sempre haver recursos disponíveis para aquisição de novas técnicas e de todo trabalho ser realizado pelas pessoas que integram o grupo familiar à adoção de uma nova técnica requer sempre a disponibilização de recursos extras e a eliminação de membros da família no processo produtivo. Em áreas de posse, por exemplo, a aquisição de novas 
técnicas é limitada mediante a expectativa que a família tem em relação à permanência nas terras.

IV - ocorreria uma absorção gradual da classe operária rural pela indústria;

V - ao final do desenvolvimento do modo de produção capitalista ocorreriam duas formas de trabalho: (a) a do trabalho industrial, do pequeno camponês, e (b) a da indústria agrícola, do grande lavrador. Se no passado a agricultura era, do pondo de vista econômico, dominante agora passa a ser a dominada. A grande indústria capitalista subverteria a agricultura e, ela, passaria a obedecer às suas ordens, adaptando-se às suas exigências. (KAUTSKY, pág. 319).

E como síntese, ao final do processo evolutivo, teríamos o aumento geral e constante dos preços dos gêneros de primeira necessidade que, conseqüentemente, recairia sobre o orçamento familiar dos trabalhadores urbanos, que constitui a massa dos consumidores; a eliminação das propriedades mais fracas, em decorrência do surgimento da concorrência internacional, e a realiança da agricultura com a indústria.

Mas, é possível que este cenário previsto por KAUTSKY, a partir das transformações que marcaram a agricultura européia durante o final do século XIX, seja tido como uma tendência a ser apontada no desenvolvimento da agricultura de países, como o Brasil, onde são encontrados modos de produção tradicionais, como camponeses, apesar das forças capitalistas dominarem à economia nacional?

Compreendemos que a introdução das forças capitalistas na agricultura nos diversos lugares não se faz de forma homogênea. O modo de produção capitalista tem revelado, nos diversos lugares onde se territorializou, em nosso país, diferentes processos de dominação e de subordinação de muitos setores econômicos da agricultura que, além da diferenciação, como demonstrou KAUTSKY, e da desintegração, como veremos logo abaixo, com base em 
relações capitalistas, mas, também outros, que se dão com base em relações nãocapitalistas.

Ao se verificar os processos percebe-se que cada um revela determinadas especificidades intrínsecas às múltiplas realidades (econômicas, sociais, culturais, etc.) que possuem nos lugares onde eles ocorrem, determinando, portanto, que a introdução de mecanismos de desenvolvimento econômico seja ajustado segundo tais especificidades.

Os capitalistas têm em comum a busca pela obtenção de lucro e por isso, investem capitais em diferentes lugares, setores e momentos históricos concorrendo entre si pela maior fatia do mercado, gerando desse modo diferentes processos com base em relações capitalistas e, às vezes, também, com base em relações não-capitalistas.

KAUTSKY demonstrou que o fim dos camponeses se daria quando a produção industrial capitalista penetrasse no meio rural. Esta penetração provocaria um processo de concorrência entre os produtores e a separação dos camponeses de seus meios de produção. Daí decorreria uma inevitável concentração de renda, sendo que as grandes propriedades capitalistas absorveriam as pequenas propriedades camponesas, e um conseqüente processo de proletarização social se estabeleceria sobre os proprietários expropriados. Mas, para que este processo ocorresse, seria necessária a existência de pelo menos uma condicionante:

O desaparecimento de muitas explorações minúsculas é assim a condição prévia indispensável para a existência de uma grande exploração. Mas isto não basta. É preciso que as pequenas explorações expropriadas formem uma superfície contínua, para que de sua fusão resulte uma grande empresa. (1985: pág. 161).

\section{3 - O Processo de Desintegração}

Os estudos de LÊNIN, sobre a pequena propriedade, foram desenvolvidos no contexto das análises que fez sobre a agricultura da Rússia em

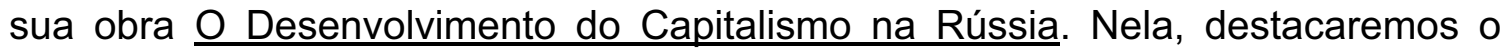


segundo capítulo, onde é desenvolvida sua teoria sobre o processo de desintegração do campesinato. É neste capítulo, onde se encontra uma das maiores contribuições, entre os autores clássicos, dos estudos sobre o destino social dos camponeses.

Ele analisou as estatísticas sobre os dados agrícolas das províncias centrais russas em conformidade com a disponibilidade que teve acesso. Assim, determinados critérios só puderam ser analisados para algumas províncias e outros para outras províncias. As estatísticas compreendiam dados sobre: $\mathrm{o} \mathrm{n}^{\circ} \mathrm{de}$ estabelecimentos; população (homens e mulheres); as áreas da terra comunitária, comprada, tomada em arrendamento, posta em arrendamento e possuída ou explorada por grupo e extensão da área semeada. As principais províncias foram: Nova Rússia, Sâmara, Saratov, Perm, Orel, Voroniej e Nijni-Novgorod.

Para analisar as estatísticas sobre os critérios mencionados acima, LÊNIN preferiu utilizar como metodologia a divisão dos proprietários em três classes sociais: os camponeses ricos ou burgueses; os camponeses pobres e os que possuíam a condição intermediária entre os ricos e os pobres que os denominou de camponeses médios.

LÊNIN chegou a seguinte conclusão após suas análises sobre a agricultura russa: "O conjunto das contradições existentes no interior do campesinato constitui o que denominamos desintegração do campesinato". ${ }^{3}$ (LÊNIN: 1985, pág.113).

Quando LÊNIN escreveu sua obra, os camponeses russos já viviam uma situação econômica caracterizada pela influência do modo de produção capitalista, pois as relações sociais entre eles em diversas províncias mostravam a existência de contradições próprias deste modo de produção.

O próprio LÊNIN constatou a existência de um conjunto de relações existentes na agricultura russa que se baseavam na concorrência; no monopólio de terras; na luta de camponeses pela independência econômica; no assalariamento da mão-de-obra e na proletarização da maioria e sua espoliação por parte da minoria, que detinha a concentração de capital e que as relações

\footnotetext{
${ }^{3}$ Grifo nosso.
} 
capitalistas já se faziam presentes no arredamento, no comércio de terras, nas "oficinas" e no progresso técnico.

Estas relações contraditórias eram, segundo LÊNIN, exclusivamente do modo de produção capitalista e se traduzia na luta e na divergência de interesses de classes e redundavam na acumulação da riqueza para alguns em detrimento ao empobrecimento de muitos. (1985: págs. 112 e 113).

Analisando, por exemplo, os dados referentes à província da Nova Rússia sobre o uso de técnicas, LÊNIN constatou que os camponeses ricos estavam muito mais equipados que os camponeses pobres e médios: "Assim, quanto mais a produção mercantil penetra a agricultura, quanto mais se agudiza a concorrência entre os agricultores, a disputa pela terra, a luta pela independência econômica, tanto maior é o vigor com que deve manifestar-se essa lei ${ }^{4}$, que conduz à evicção do campesinato pobre e médio pela burguesia camponesa". (ibidem: pág. 39).

O campesinato pobre era constituído, segundo ele, pelo grupo de camponeses que produzia pouco ou nada e se comparados pela situação econômica quase não havia diferença entre eles. Uns trabalhavam como assalariados, quase sempre em tarefas agrícolas, na mesma aldeia ou em suas proximidades integrando-se ao universo do proletariado rural. (Ibidem. Pág. 39 e 41).

Já sobre o campesinato médio, ele afirmou que a situação era intermediária, isto é, a renda que conseguia extrair da agricultura era um pouco inferior à soma que gastava anualmente. Um dos camponeses médios da província de Táurída, por exemplo, possuía 3,2 animais de tração por estabelecimento, quando, para cobrir suas necessidades, precisaria de pelos menos 4. Por isso, a sua exploração era inevitável e, para trabalhar a sua terra, ele era obrigado a recorrer à associação com outros camponeses. (Ibidem, pág. 42).

\footnotetext{
${ }^{4}$ Esta lei, a que se refere Lênin, foi extraída da obra de V. Postnikov A Economia Camponesa da Rússia Meridional. Moscou, 1891. p. 117. "Á medida que aumenta a exploração e a superfície da terra cultivada, os custos da força de trabalho (homens e animais) - esse gasto fundamental na agricultura - diminuem progressivamente e, nos grupos que semeiam muito, eles são, por deciatina semeada, quase duas vezes inferiores àqueles dos grupos que semeiam menos".
} 
LÊNIN atribuiu especial atenção para a conclusão a que chegou de que o modo de produção capitalista se traduzia na luta e na divergência de interesses de classes e redundava na acumulação da riqueza para alguns em face da pobreza de muitos. Isto evidenciava o fato de que o sistema de relações econômicas, existentes na comunidade rural não constituía, em hipótese alguma, uma forma particular (a produção popular), mas um habitual sistema pequeno-burguês. Contrariamente ao que pensavam os populistas, ele chega a afirmar que o campesinato russo não era uma comunidade antagônica ao capitalismo, mas, ao contrário, “(...) era a sua base mais profunda e sólida”. (1985: Pág. 113).

Era a base mais profunda do capitalismo porque, segundo ele, era mesmo no interior do campesinato que se constatavam a formação de elementos capitalistas. E era também sólida, porque sobre ela pesavam as mais tradicionais relações sociais (da Antiguidade e do patriarcalismo), que funcionavam como um meio de resistência à entrada das forças do capitalismo na agricultura. Foi, principalmente, em função da ocorrência desta contradição verificada no interior da agricultura russa, que LÊNIN denominou sua teoria de desintegração do campesinato.

As contradições eram resultado das desigualdades econômicas existentes entre os produtores e acarretava, não apenas uma diferenciação entre eles, mas a destruição completa do antigo campesinato que seria substituído por outras novas classes sociais, peculiares ao modo de produção capitalista: a da burguesia rural, que constituiria a classe dos produtores de mercadorias na agricultura, e a do proletariado rural, que formaria a classe dos operários agrícolas assalariados.

Portanto, em tese a classe da burguesia seria constituída por produtores independentes, que praticariam a agricultura mercantil, pelos proprietários de estabelecimentos industriais e os das empresas comerciais cuja especificidade seria combinar a produção da agricultura com a da indústria. Enquanto isto, sua contradição seria a classe do proletariado rural, constituída pelo campesinato pobre e o campesinato sem terra, que seriam a personificação do assalariado agrícola, do diarista, do peão, do operário da construção e todos os demais operários assalariados. 
Interpondo-se entre as duas classes, haveria ainda o campesinato médio. Esta classe, em síntese, seria fruto do desenvolvimento da burguesia rural e do proletariado rural e o elo intermediário entre elas. A situação de instabilidade econômica em que esta classe viveria, ora contraindo dívidas, ora desenvolvendo trabalho acessório para pagar suas dívidas, aliada aos períodos de colheita ruim levaria massas de camponeses médios à proletarização. Ela oscilaria entre a classe da burguesia rural e a classe do proletariado rural, para onde a maioria submergiria empurrada pelo processo de evolução social. Dessa forma, a burguesia rural promoveria a proletarização, não apenas do campesinato pobre, mas também do campesinato médio.

Para LÊNIN, o mercado consumidor interno surgiria a partir da formação e ascensão da burguesia camponesa que, se por um lado o campesinato rico converteria seu capital em meios de produção formando assim o mercado consumidor interno, por outro, ele seria impulsionado pelo consumo pessoal dos camponeses que tivessem melhores condições.

Além do mais, ocorreriam movimentos migratórios de camponeses médios, principalmente das províncias agrícolas, que abandonariam as terras em busca de outras condições nas cidades, o que intensificaria ainda mais a proletarização urbana. Outros camponeses, com melhores condições, comprariam ou arrendariam mais terras e, outros ainda, conseguiriam comprar máquinas e implementos, etc. a fim de melhorar seus estabelecimentos o que, também, contribuiria para aumentar o mercado interno.

Sobre os dados das estatísticas da província de Perm, por exemplo, LÊNIN conclui que "Se confrontamos esses dados com os relativos à distribuição da superfície semeada e ao emprego de operários assalariados, vemos mais uma vez que a desintegração do campesinato cria um mercado interno para o capitalismo". E em relação à província de Orel constatou a existência de um relativo mercado que foi considerado por ele como inferior aos dos demais das províncias com relação ao tamanho da exploração agrícola dos camponeses: "Na província de Orel, como nas outras, testemunhamos a desintegração do campesinato em dois tipos diametralmente opostos: de um lado, o proletariado 
rural (que abandona a sua terra e vende a sua força de trabalho) e, doutro, a burguesia camponesa (que compra terras, arrenda grandes extensões, especialmente dos lotes comunitários, aperfeiçoa os seus métodos de exploração, emprega operários e diaristas e incorpora empresas industriais e comerciais à agricultura)". (1985, pág. 69).

E ainda sobre o resultado geral dos orçamentos dos camponeses, LÊNIN afirma que os dados "revelam que, transformando o camponês, de um lado, em operário agrícola e, doutro, em pequeno produtor de mercadorias, em pequenoburguês, a desintegração do campesinato cria um mercado interno para o capitalismo. Desses dados podemos tirar outra conclusão não menos importante: em todos os grupos do campesinato a economia já se tornou comercial em grau bastante considerável e já depende do mercado (...) Na sociedade contemporânea não se pode viver sem vender, e tudo o que trava o progresso da economia mercantil conduz ao agravamento da situação dos produtores". (idem, pág. 99).

Enfim, ao estudar o desenvolvimento do capitalismo e, particularmente, a formação do mercado interno na Rússia, LÊNIN elabora sua teoria sobre a desintegração dos camponeses, chega à conclusão de que o desenvolvimento do capitalismo na agricultura leva os camponeses pobres a um processo de proletarização de um lado, e o fortalecimento do campesinato rico, de outro. Haveria assim, na nova sociedade dominada pelo modo de produção capitalista, uma ampla divisão social bipolar: em um dos pólos, se encontraria a classe da burguesia rural, formada pela minoria rica dos habitantes no outro, a classe dos camponeses pobres, constituída pela grande massa dos camponeses proletários.

Ao fim dos processos de desintegração e de descamponização, os camponeses pobres e médios teriam sido completamente eliminados do campo onde restariam relações capitalistas. Sobraria, por fim, uma massa espoliada de camponeses empobrecidos e proletarizados pelo campesinato rico, proprietário das terras e dos meios de produção: o senhor dos campos!

Nos estudos de KAUTSKY, o progresso técnico é inerente à diminuição de custos, mas o seu emprego nas pequenas propriedades camponesas poderia significar um entrave à entrada das forças capitalistas na agricultura. Neste caso, 
a difusão de relações capitalistas na agricultura dependeria da entrada de capitais no meio rural para forçar os proprietários pobres a venderem ou arrendarem suas terras ou ainda contraírem dívidas para melhorar as condições de seus estabelecimentos.

Para KAUTSKY, a entrada de capital industrial na agricultura provoca os processos da concorrência e o da diferenciação, entre os camponeses, e o de separação, entre os meios de produção e os camponeses, resultando numa proletarização universal, enquanto que para LÊNIN, a desintegração dos camponeses seria fruto do desenvolvimento da indústria que fatalmente subjugaria as atividades agrícolas e, conseqüentemente, a produção camponesa que por sua vez perderia os meios de produção, inclusive as terras, e os trabalhadores camponeses tornar-se-iam proletários.

Apesar da ocorrência destes processos, tanto o da diferenciação kautskyana quanto o da desintegração leninista, verificáveis na história passada e na atualidade do desenvolvimento do campo brasileiro, temos que considerar que tais processos, tendo em vista as particularidades de cada setor e lugar da agricultura brasileira, não se processaram em sua plenitude e nem eliminaram completamente as formas de produção tradicionais existentes até hoje na nossa agricultura. Isto quer dizer que nos diferentes lugares e setores da agricultura brasileira há diferentes processos, quanto ao conteúdo, existindo, contemporaneamente, e que podem apresentar variações segundo a forma com relação à origem histórica, aos meios de produção, à posse da terra, ao tamanho da propriedade, às técnicas empregadas, à mão-de-obra, etc.

Contrapondo-se às teorias da Diferenciação e da Desintegração do Campesinato foi desenvolvida, também por autores marxistas, a teoria da Recriação Camponesa, que será analisada no quarto tópico a seguir.

\section{4 - O Processo de Recriação Camponesa}

Veremos neste tópico que os autores que estudam o campo brasileiro, inseridos numa perspectiva que hoje denominamos de via campesina, compreendem que existem diferentes processos ocorrendo no campo brasileiro, 
sendo que a desintegração e a diferenciação são apenas exemplos destes processos. Embora haja divergência entre eles quanto à forma de se compreender e de se conduzir os diferentes processos sociais, todos, no entanto, partem do pressuposto, assim como MARX, de que é a luta de classe que produz o movimento histórico, o devir, como fator primordial que dá movimento aos processos sociais.

GUIMARÃES (1985), ao se referir à formação do campesinato brasileiro, afirma que a "pequena propriedade é um produto da luta de classe, travada sempre em desigualdade de condições, entre os camponeses sem terra e a classe latifundiária”. (1985, pág. 151).

Tal afirmação carrega, talvez, toda a síntese do pensamento marxista, cuja obra se desenvolve em torno da teoria da luta de classe conforme observou ENGELS no Prefácio para a terceira edição alemã do 18 BRUMÁRIO DE LUÍS BONAPARTE: "Fora precisamente Marx quem primeiro descobrira a grande lei da marcha da história, a lei segundo a qual todas as lutas históricas $\{. .$.$\} são na$ realidade apenas a expressão mais ou menos clara de lutas entre classes sociais". (2002, pág. 18).

Isto significa dizer que, apesar de constatarmos a ocorrência do processo de diferenciação no bairro onde realizamos nossos estudos, temos o entendimento de que a expansão do modo de produção capitalista no meio rural, não somente engendrou novos processos na agricultura como também trouxe à luz processos tradicionais de produção ainda existentes na agricultura brasileira, que são contrários a esse modo de produção. Desse modo, compreendemos que tal expansão serviu não somente para engendrar novos processos, mas, também, para revelar que não há apenas um processo e nem mesmo um só sistema de produção, mas há processos e sistemas e diferentes relações sociais ocorrendo simultaneamente na agricultura brasileira, sendo uns mais dominantes que outros dependendo do setor e do lugar onde eles ocorrem.

MARTINS (1996), ao estudar a produção capitalista realizada sob relações não-capitalistas, compreende que o capitalismo, na sua expansão, não só redefine as antigas relações como também insere no processo produtivo 
relações não-capitalistas que são iguais e contraditoriamente necessárias à reprodução capitalista.

OLIVEIRA (1997), entretanto, é o autor que melhor sistematizou a teoria sobre a Recriação Camponesa ao constatar, em seus estudos, que a produção capitalista se difundiu por todo território brasileiro estabelecendo relações de produção capitalistas, mas também, ampliou as relações de trabalho nãocapitalistas.

Se, de um lado, o capitalismo avançou em termos gerais por todo o território brasileiro, estabelecendo relações de produção especificamente capitalistas, promovendo a expropriação total do trabalhador brasileiro no campo, colocando-o nu, ou seja, desprovido de todos os meios de produção; de outro, as relações de produção não-capitalistas, como o trabalho familiar praticado pelo pequeno lavrador camponês, também avançaram mais. (OLIVEIRA, 1997 p. 11).

As formas sociais não-capitalistas como o campesinato; o latifúndio; o colono; a parceria, etc., existentes até hoje na agricultura brasileira, são frutos do próprio desenvolvimento contraditório do modo de produção capitalista que, ao se desenvolver, tem permitido a (re) criação destas relações de trabalho nãocapitalistas.

Esta contradição, segundo nosso entendimento, é decorrente de dois mecanismos, apontados por OLIVEIRA (1997), como resultado do monopólio do capital com relação à produção no campo: (I) ora a produção é subordinada à circulação e (II) ora a circulação é subordinada à produção.

O capital tem se aproveitado desta contradição para sujeitar a produção das pequenas unidades e extrair a renda da terra. Quando os agricultores têm a propriedade da terra a sujeição se dá no momento da circulação.

Mas, como lembra OLIVEIRA (1997), estes mecanismos têm levado hoje os camponeses à gestação de um movimento contrário, que os une e os organiza como classe social, cuja bandeira tem sido a da liberdade de produzir.

No passado, a luta pela liberdade de produzir, que se colocava como uma condição de vida para camponeses e colonos, já denunciava os mecanismos de monopólio na agricultura brasileira. 
No início do século passado, o acesso a pequenos lotes de terra (as chamadas chácaras) por parte dos colonos imigrantes que souberam ou puderam economizar, pode ter ocorrido em muitos lugares em razão de muitos fazendeiros cafeicultores, cujas terras haviam se esgotado, terem loteado e vendido suas fazendas, ocasionando uma fragmentação territorial da área. Abrindo, assim, possibilidades para que os camponeses colonos pudessem se tornar proprietários.

Se, por um lado, a baixa qualidade das terras não possibilitava uma elevada renda fundiária aos fazendeiros, por outro, a venda de uma grande quantidade de lotes proporcionaria o capital necessário para a aquisição de outras terras, mais produtivas, em outras regiões.

Para MARTINS (1986), ao mesmo tempo em que o mercado de terras criava possibilidades para a introdução do campesinato, da mesma forma lhe impunha a incumbência de produzir alimentos tradicionais para o mercado interno. Esta peculiaridade somada ao fato de a produção camponesa ocupar áreas de baixa renda fundiária explica porque ela encontra tantas dificuldades. Os camponeses produzem excedentes para o mercado em condições desvantajosas e, também por isso, não conseguem acumular recursos suficientes para investir e melhorar sua produtividade. Além disso, há outros fatores, por exemplo, no caso dos agricultores do bairro de Santo Ângelo que possuem unidades de produção localizadas nas áreas de várzeas a falta de investimentos se justifica tanto pela baixa renda adquirida, pela comercialização da produção, quanto pela incerteza de se continuar ocupando as terras.

Um exemplo histórico foi o que ocorreu nos tempos da grande lavoura cafeeira com grande número de colonos japoneses que emigraram para o Brasil com o sonho de fazer dinheiro fácil para voltar ao seu país: a possibilidade de comprar um pequeno lote de terra era o início da concretização do sonho, mas as dificuldades na fazenda quase o impossibilitavam. A alternativa encontrada por muitos foi economizar recursos, até o limite da sobrevivência, para conseguir comprar um pequeno lote de terra a fim de garantir a liberdade econômica, mesmo que se encontrasse distante dos centros consumidores. 
Assim, ao mesmo tempo em que a relação de trabalho capitalista se expandia na agricultura criava, também, contraditoriamente, as condições para os camponeses adquirirem terras.

OLIVEIRA (1997) lembra, ainda, que o capitalismo, ao se implementar na agricultura brasileira, desenvolveu processos que permitiram que relações de trabalho não-capitalistas fossem recriadas. Estes processos, necessários para que o capitalismo se desenvolva, recriam certas relações de trabalho que são contraditórias à lógica do modo de produção capitalista como, por exemplo, o trabalho familiar camponês.

O desenvolvimento capitalista se faz movido pelas suas contradições. Ele é, portanto, em si, contraditório e desigual. Isso significa que para seu desenvolvimento ser possível, ele tem que desenvolver aqueles aspectos aparentemente contraditórios a si mesmo. (OLIVEIRA: 1997 pág. 18).

Um exemplo prático desta contradição se verificava durante a expansão capitalista no Centro-Oeste do país: no Mato Grosso, era comum o fazendeiro entregar uma parte das terras, ainda com mata nativa, aos camponeses para que eles desmatassem e plantassem (por um curto período de tempo, que podia variar entre um e três anos arroz, feijão, mandioca e outros produtos), para em seguida semear capim, que seria transformado em pastagens. Desse modo, o camponês, ao entregar as terras de volta ao fazendeiro, evitava que este gastasse capital e recursos com mão-de-obra para desmatar e semear o capim de suas terras.

OLIVEIRA (1994) tem demonstrado que são numerosos os processos engendrados pela expansão do modo de produção capitalista na agricultura brasileira: o de produção do capital; da transformação dos camponeses em capitalistas; da mundialização da economia brasileira; da territorialização do capital; do trabalho assalariado e o trabalho familiar camponês e a unidade contraditória entre a cidade e o campo. Todos eles são considerados contraditórios, por que ao serem engendrados na agricultura pela expansão capitalista, esta, da mesma forma, engendra relações sociais que recriam o campesinato ao desenvolver o trabalho não-capitalista. 
Mas, estes processos têm gerado graves problemas na agricultura: de um lado a concentração fundiária, e por outro, a violência no campo, sofrida pelos camponeses que são suas maiores vítimas.

É, pois, no bojo dessa articulação entre o processo de expansão desigual do trabalho assalariado no campo, na expansão do também desigual processo de expropriação, e no dominante processo histórico da concentração fundiária do país, que vamos encontrar contraditoriamente a origem dos conflitos e da luta pela terra no Brasil com sua marca histórica: a violência. (OLIVEIRA, 1994, pág. 67).

A luta pela propriedade coletiva dos meios de produção, isto é, a defesa por uma sociedade socialista, como solução para os problemas agrários, é passo fundamental no processo de luta dos camponeses contra os capitalistas. Isso porque para os camponeses, não basta apenas a propriedade coletiva, são necessários, também, a posse, o controle e a administração coletiva sobre todos os meios de produção.

Para OLIVEIRA (1994), o debate sobre esta questão coloca em discussão, inevitavelmente, o caráter da democracia nesta nova sociedade. Mas, compreende que a prática dessa luta somente pertence aos trabalhadores. E, portanto, dever-se-ia dar toda liberdade às suas assembléias. Porque, para nós outros (os intelectuais e estudiosos da sociedade) caberia o papel de ver, ouvir e organizar a luta de classe, enquanto que a tarefa dos geógrafos se limitaria a compreensão do processo de luta de classe.

Nosso papel nesse particular constitui-se em ver e ouvir. Pois já é hora de entendermos que são os trabalhadores - os maiores interessados na transformação da sociedade - que devem falar. A nós geógrafos cabe uma tarefa talvez pequena na luta teórica: estudar, entender, compreender a luta pela terra, a luta armada pela terra. (OLIVEIRA: 1994 págs. 14 e 15).

Já STÉDILE (1994), que considera que a Reforma Agrária seria apenas o início do processo de transformação social, compreende que o problema agrário hoje no Brasil é decorrente da entrada no campo das três formas clássicas de 
atuação do capitalismo que julga constituiem-se num modelo de graves conseqüências sociais.

A primeira forma se refere ao processo de acumulação de capitais - em que os grandes proprietários estimulados pelas políticas públicas de créditos fáceis e subsídios a determinadas lavouras passaram a acumular capitais rapidamente; a segunda foi a da concentração de capitais - que possibilitou aos grandes proprietários investir na compra de mais terras; e a terceira, foi a da centralização de capitais - que possibilitou aos capitalistas rurais deslocar parte do capital para outros setores da economia. Considera ainda, que a introdução da agroindústria na agricultura brasileira, durante as duas últimas décadas, também contribuiu consideravelmente para o agravamento do problema agrário ao estimar que praticamente $80 \%$ dos produtos consumidos pela população urbana, com exceção dos legumes e verduras das feiras, passam por um processo de industrialização.

Então, segundo se pode deduzir do entendimento de STÉDILE é que o capitalismo teria acabado com as alternativas, de um outro modelo de agricultura, para a pequena propriedade e, quando não acabou pelas leis de mercado, acabou pelas leis do governo. (STÉDILE: 1994, pág. 315).

As conseqüências deste modelo, segundo STÉDILE, por um lado, é a exploração de 23 milhões de trabalhadores: sendo 6 milhões de assalariados, 8 milhões de sem terra, que trabalham como arrendatários, parceiros e posseiros, e mais 8 milhões de pequenos agricultores que também são explorados mediante a subordinação aos mecanismos de preços, de crédito ou da agroindústria. ${ }^{5} \mathrm{E}$ por outro, a concentração de terras: dos 354 milhões de hectares, que estão titulados e que são as melhores terras e onde vive a população, apenas 64 milhões são cultivados, com lavouras permanentes e temporárias, o restante encontra-se parado. $\mathrm{E}$ o resultado disso tudo tem sido a migração de milhares de trabalhadores do campo para a cidade. (STÉDILE: 1994, págs. 317/318).

\footnotetext{
${ }^{5} \mathrm{O}$ autor fala de total de 23 milhões, mas faz referência a apenas 22 milhões (6 milhões mais 8 milhões mais 8 milhões). O restante que corresponde a 1 milhão não foi explicado.
} 
Entende que diante desse quadro, a solução seria a Reforma Agrária. Mas, para ele, uma reforma na estrutura agrária, necessariamente teria que atingir os processos capitalistas introduzidos na agricultura, devolver aos milhões de trabalhadores, o direito à cidadania e organizar a propriedade coletiva dos meios de produção. Seria, portanto, mais que uma Reforma Agrária. O que está sendo pretendido é uma transformação social plena, isto é, uma sociedade socialista.

Para nós, apesar de admitimos que as relações de trabalho capitalistas já estão bastante difundidas na agricultura brasileira, compreendemos, também, que o desenvolvimento do modo de produção capitalista se faz movido por suas contradições. A (re) produção e a permanência da pequena unidade na agricultura brasileira é, portanto, produto do próprio modo de produção capitalista.

Não poderemos compartilhar com a falsa idéia de que o desenvolvido do capitalismo na agricultura brasileira provocará a extinção de todas as pequenas propriedades rurais ou a homogeneização das relações de trabalho. Nem tão pouco participar da idéia de que os processos de desintegração e da diferenciação concorrem unicamente para a universalização da proletarização de todos os camponeses, em todos os tempos e lugares. Mas, por outro lado, compreendemos que se este modelo de sociedade em que vivemos não é capaz de promover a igualdade social devemos, portanto, ouvir, como alerta OLIVEIRA, à vontade dos trabalhadores.

Saber qual é o papel e o lugar das pequenas unidades rurais na agricultura brasileira é fundamental, para a compreensão dos processos sociais de toda sociedade, quer seja no campo ou na cidade, pois o que se deve está em discussão não é simplesmente o trabalho de 23 milhões de pessoas, mas o resgate da dignidade social de cada uma delas. "Ou nós entendemos o processo de desenvolvimento do capitalismo no campo, ou então, continuaremos vendo muitos autores falarem que os camponeses estão desaparecendo, mas, entretanto, eles os camponeses, continuam lutando para conquistar o acesso às terras em muitas partes do Brasil”. (1994, págs. 4 e 5). 


\section{CAPÍTULO II - A ORGANIZAÇÃO DA PRODUÇÃO CAMPONESA EM BAIRROS RURAIS}

Ao estudar como se organizava e funcionava a sociedade rural em função das rápidas transformações que ocorreram, no fim do século XVII, e a entrada de milhares de imigrantes europeus no campo paulista, QUEIROZ (1973), verificou a existência de diferentes formas de agrupamentos e de vida cultural no meio rural, sendo uma delas o bairro rural.

O estudo sobre este tipo de agrupamento social foi sistematizado na obra Bairros Rurais Paulistas de autoria da professora MARIA ISAURA PEREIRA DE QUEIROZ, publicada em 1973, sobre a qual apoiamos nossas análises sobre o estudo que realizamos no bairro rural de Santo Ângelo.

Ela destaca como sendo elemento fundamental ao estudo dos bairros rurais o sentimento de localidade como aquele que delimita a configuração geográfica e social aos bairros rurais e era este tipo de agrupamento social que mais se achava em processo de desagregação no meio rural paulista durante a década de 1960. É, sobretudo, em função disto que as nossas abordagens dão um destaque a esse elemento (o sentimento de localidade) e aos processos sociais (diferenciação e desintegração) existentes no interior do bairro de Santo Ângelo.

Na pretensão de realizarmos uma melhor organização do nosso trabalho, preferimos introduzir o leitor inicialmente em duas análises sobre bairros rurais: uma conceitual e a outra descritiva. Em seguida, apresentamos nossas impressões e análises sobre o bairro de Santo Ângelo, onde realizamos nosso estudo empírico.

Assim, no primeiro tópico (2.1) dialogamos com QUEIROZ sobre o seu conceito de bairro rural, mas numa perspectiva mais econômica que propriamente cultural e no segundo tópico (2.2), descrevemos analiticamente os principais elementos constitutivos de dois bairros rurais paulistas estudados por QUEIROZ: o de Laranjeiras e o de Palmeiras, ambos localizados no município de Itapecerica da Serra. O terceiro tópico (2.3) foi dedicado às analises sobre os elementos que 
identificamos no bairro de Santo Ângelo. Tivemos como pretensão a de determinar se os elementos que identificamos, em Santo Ângelo, eram comuns ou se havia distinção entre eles e os dos bairros estudados por QUEIROZ e quais os processos sociais que se desenvolviam e em que nível de desestruturação econômica se encontravam, uma vez que para QUEIROZ estes processos já se encontram em desenvolvimento desde a década de 1960 na agricultora paulista.

Sempre que foi necessário, fizemos algumas contraposições às conceituações que se colocaram, por considerá-las necessárias à contextualização do conjunto do nosso trabalho.

\section{1 - Conceituação de Bairro Rural}

Os bairros rurais paulistas, segundo QUEIROZ, eram formados por um grupo de vizinhos, cujas famílias, apesar das moradias dispersas, mantinham entre si relações sociais consistentes que se traduzia num sentimento de localidade do lugar em que habitavam. Este sentimento consistia elemento básico para delimitar a configuração de um bairro, tanto no espaço geográfico quanto no espaço social. Vejamos abaixo, como o bairro rural foi caracterizado por ela:

Era o bairro rural um grupo de vizinhos de "habitat" disperso, mas de contornos suficientemente consistente para dar aos habitantes a noção de Ihe pertencer, levando-os a distingui-lo dos demais bairros da zona. $O$ "sentimento de localidade" constituía elemento básico para delimitar a configuração de um bairro, tanto no espaço geográfico quanto no espaço social. Tradicionalmente, uma capela marcava o núcleo de reunião para os componentes dispersos pelas cercanias, - momento em que se afirmava a personalidade do bairro, em relação aos bairros vizinhos. Cada bairro se compunha de famílias conjugais autônomas, autárquica, lavrando independentemente suas roças quando e como queriam. Não podiam, porém, prescindir do auxílio dos vizinhos sem grave diminuição de seus recursos, pois suas técnicas eram as mais rudimentares. O mutirão, a troca de dias de serviço e outras formas de auxílio mútuo eram as soluções adotadas para resolver a escassez de mão de obra, por um lado, e, por outro lado, a escassez de meios para obtê-la; pois cultivar a terra apenas com os braços da família não era muito produtivo, não havendo também 
dinheiro para comprar escravos e, mais tarde, para alugar assalariados. $\mathrm{O}$ trabalho rural em comum se tornava assim uma segunda maneira de congregar os habitantes do bairro, além da festa religiosa. (QUEIROZ, 1973, págs. 3 e 4). ${ }^{6}$

Outros elementos, considerados ainda por QUEIROZ, incluía a existência de uma capela no bairro, que marcava o núcleo central do bairro; a festa ao padroeiro, que constituía momentos de reuniões e encontros entre os moradores e marcava a identidade do bairro; a autonomia das famílias, que cultivavam a terra independentemente de uma das outras; o auxílio mútuo, que se praticava através do mutirão ou da troca de dias de trabalho; e o trabalho familiar, pois as famílias não possuíam condições econômicas suficientemente para comprar máquinas nem para pagar trabalhadores assalariados. Assim, o trabalho rural em comum se tornava uma segunda maneira de congregar os habitantes, além da festa religiosa.

Podemos, assim, identificar os seguintes elementos, segundo QUEIROZ, que são constitutivos e fundamentais para existência de um bairro rural: $\underline{o}$ sentimento de localidade (1); a existência da capela (2): a independência das famílias (3); o auxílio mútuo (4) e o trabalho familiar (5).

Estabelece-se a partir de tais elementos uma estreita rede de relações sociais entre os próprios moradores do bairro, que pelas quais se adquire a consciência da unidade e do funcionamento e do sentimento de localidade. A rede de relações sociais se configura, portanto, numa intermediação entre a família, de um lado, e de outro as localidades que estiverem em sua volta, o arraial, a vila ou mesmo a cidade. Dessa forma, é a partir do bairro que a sociabilidade se alarga em diferentes níveis atingindo as escalas das relações familiares; das relações de vizinhanças; das relações dos bairros entre si; das relações com a região e das relações com tudo aquilo que ultrapassa a região. E tais graduações, indicam que os bairros, apesar de certa autonomia, são sempre tributários de uma cidade.

Internamente os bairros rurais, estudados por QUEIROZ, se estruturam de maneira igualitária não havendo diferenciação social hierárquica muito desenvolvida e definida entre seus moradores e que moram em casas precárias e

\footnotetext{
${ }^{6}$ Grifos nossos.
} 
utilizam técnicas tradicionais no cultivo e na fabricação de utensílios domésticos, de roupas e de alimentos que consumem. A sobra excedente da produção vegetal e animal se destina ao mercado, geralmente nas cidades mais próximas, a fim de se adquirir dinheiro para o consumo de algum produto não produzido pela família.

Esta descrição da maneira de viver dos moradores dos bairros rurais paulistas durante a década de 1960, simplificada aqui por nós, sugere que o agricultor era o principal consumidor da sua produção e não visava lucro com o cultivo da terra.

Entretanto, a relação existente entre o consumo e a produção é, no limite da racionalidade, todo ato que se estabelece entre o homem e a natureza.

MARX (1978) considera que a produção é, imediatamente, um ato de consumo. Em primeiro lugar, é um ato subjetivo, pois $O$ "indivíduo, que ao produzir desenvolve suas faculdades, também as gasta, as consume, no ato da produção, exatamente como a reprodução natural é um consumo de forças vitais. E, em segundo lugar, é também um ato objetivo, pois produzir é consumir os meios de produção utilizados, e gastos, parte dos quais $\{\ldots\}$ dissolve-se de novo nos elementos universais. Também se consome a matéria-prima, a qual não conserva sua figura e constituição naturais, esta ao contrário é consumida. $\underline{0 \text { próprio ato de }}$ produção é, pois, em todos os seus momentos, também ato de consumo". ${ }^{7}$ (MARX, 1978, págs. 108 e 109).

Desse modo, conclui-se que a produção se realiza no consumo e o consumo, por sua vez, só se realiza mediante a produção. Assim, produção e consumo são duas faces contraditórias de um só processo, o da circulação de mercadorias, que só se realiza mediante uma na presença da outra.

Mas, nas sociedades capitalistas, como adverte MARX, a circulação das mercadorias é realizada mediante o dinheiro, que como meio de circulação comum à produção e ao consumo, aparece sempre como meio de compra, com a qual suas "diferentes determinações tornaram-se irreconhecíveis nas fases opositivas em que se dá a metamorfose das mercadorias". (MARX, 1978, pág. 189).

\footnotetext{
${ }^{7}$ Grifo nosso.
} 
E ao desenvolver sua teoria sobre as formas simples e geral da circulação das mercadorias, considera que a forma simples (M-D-M) tem por pondo de partida uma mercadoria e por ponto final outra mercadoria. "Seu objetivo, portanto, é consumo, satisfação de necessidades, em uma palavra, valor-de-uso". Enquanto a forma ampla (D-M-D), ao contrário, tem no dinheiro os pontos de partida e de chegada, isto é, "tem por ponto de partida o dinheiro e retorna ao mesmo ponto. Por isso, é o próprio valor-de-troca o motivo que o impulsiona, o objetivo que o determina". (MARX: 1968, pág. 169).

MENDRAS (1978) considera que o valor do dinheiro, nas sociedades camponesas, serve essencialmente de instrumento de transação entre o lugar que ele tem na economia capitalista e o lugar que ele assume na "economia" camponesa. " $\{\ldots\}$ serve essencialmente de instrumento de transação entre as duas", sendo que é no mercado onde esta transação se estabelece: "na feira onde vende $\{\ldots\}$ seus produtos e com o dinheiro que recebe em troca paga seus impostos $\{\ldots\}$, o aluguel da fazenda a seu proprietário, compra sal e os demais produtos que não fabrica por si só e volta para casa livre de suas dívidas e munido do que lhe é necessário, mas sem dinheiro". (MENDRAS, 1978, pág. 49).

Desse modo, os agricultores dos bairros rurais, ao destinar a produção ou parte dela para os mercados seguem uma lógica diferentemente daquela dos produtores capitalistas.

OLIVEIRA (1997) considera que a lógica da produção camponesa é explicada pelo movimento expresso na fôrmula M-D-M e, por conseguinte, a lógica dela está assentada na forma simples de circulação das mercadorias, onde se tem a conversão da mercadoria em dinheiro e a do dinheiro em mercadoria, isto é, na venda de mercadoria para adquirir dinheiro para adquirir uma outra mercadoria.

Mas, para a Sociologia Rural, segundo QUEIROZ, a questão do produtor consumir o que produz tem sido utilizada como critério para diferenciar um tipo de lavrador, o camponês, do agricultor: "O primeiro vive do que produz, e utiliza para troca ou venda aquilo que não emprega no consumo diário; o segundo produz para um mercado local, regional ou internacional, seu primeiro objetivo é o lucro e em geral se especializa no cultivo de um ou dois produtos; sua própria 
subsistência não depende do que planta, e sim da venda da colheita, que lhe permitirá adquirir o que não cultiva. A condição do camponês, levada às ultimas conseqüências, significa que o indivíduo vive isolado em sua propriedade cultivando na roça e sem necessidades do mundo exterior; enquanto a condição do agricultor se define como estreitamente dependente da cidade ou de outras áreas agrícolas". (QUEIROZ: 1973, págs. 5 e 6).

Entretanto, contrariamente ao que diz a Sociologia Rural, QUEIROZ adverte que os dois tipos são produtores autônomos e independentes, cujo trabalho é executado apenas com os membros da família, a qual lhe cabe a iniciativa e a responsabilidade da produção. A família pode dispor da totalidade ou de uma parte da produção, podendo destinar o que excede ao mercado e, isto, os diferem muito dos outros tipos existentes da agricultura brasileira, como o latifundiário, o fazendeiro, o grande pecuarista, etc., isto é, dos capitalistas. "Para se definirem como camponeses, precisam conservar a autonomia de seu trabalho e o direito à disposição de pelo menos parte do produto. Caso contrário, deverão ser definidos como dependentes ou como assalariados". (QUEIROZ, 1973, pág. $6)^{8}$.

TAVARES DOS SANTOS $(1978)^{9}$ caracteriza a produção camponesa a partir da força de trabalho familiar; da ajuda mútua; da parceria; do trabalho acessório; da força de trabalho assalariada; da socialização; da propriedade da terra; da propriedade dos meios de produção; da jornada de trabalho e da reprodução simples da produção camponesa.(1978: págs. 25-67).

OLIVEIRA (1990) considera que o camponês, de posse destes elementos (os quais TAVARES DOS SANTOS fez referência), é um produtor especializado de mercadorias e que possui ainda uma invejável capacidade produtiva, mas que nem por isso deve ser considerado um assalariado disfarçado ou um trabalhador a domicílio.

Desse modo, os elementos da produção camponesa em nada contradizem os identificados nos bairros rurais. Exceto o sentimento de localidade,

\footnotetext{
${ }^{8}$ Grifo nosso.

${ }^{9}$ Nesta obra, TAVARES DOS SANTOS, faz uma caracterização profunda sobre cada um dos elementos que compreendia serem integrantes da produção camponesa.
} 
considerado por QUEIROZ como elemento básico para a delimitação e configuração do bairro rural, todos os demais são constituintes daqueles identificados por TAVARES DOS SANTOS e reafirmados por OLIVEIRA.

Assim, para nós, o bairro rural compreende um agrupamento de agricultores camponeses cujas especificidades baseiam-se na existência de cinco elementos fundamentais: (a) no sentimento de localidade; (b) no trabalho familiar que seja orientado para a reprodução do grupo social e não para a lógica do lucro; (c) no ideal da terra de trabalho e não, simplesmente, como uma mercadoria concebendo-a em si mesma como um bem natural; (d) na propriedade ou autonomia dos meios de produção e (e) na produção de mercadorias, como pressuposto de sustento do grupo familiar, cuja lógica pode ser representada pela fôrmula da cumulação primitiva de MARX (M-D-M), isto é, na produção de mercadorias para adquirir dinheiro para adquirir mercadorias necessárias ao consumo do grupo familiar.

E ainda, devemos compreender também que dadas as multiplicidades de diversos processos sociais existentes atualmente na agricultura brasileira não se pode engessar os conceitos elaborados anteriormente, pois os habitantes de um bairro rural poderão ser trabalhadores de diversas ocupações e níveis socioeconômicos distintos, como é em toda sociedade mais ampla, podendo residir moradores não-agricultores, que subsistem com a renda do assalariamento rural ou urbano; e moradores camponeses, que subsistem com a obtenção da renda fundiária, e ainda pequenos capitalistas, cuja condição socioeconômica seja superior aos demais moradores do bairro por conseguirem acumular capital tornando sua produção distanciada e diferenciada dos demais agricultores.

Tais processos são verificáveis no bairro de Santo Ângelo, como veremos a seguir no último tópico deste capítulo.

\section{2 - Principais Elementos Constitutivos de Bairros Rurais}

O estudo desenvolvido por QUEIROZ abarcou quatro municípios paulistas: em Taubaté sobre o bairro da Bacia do Ribeirão das Antas; em Leme sobre o bairro de Taquari; em Paraibuna sobre os bairros de Itapeva, Campo 
Redondo e Bragança e em Itapecerica da Serra sobre os bairros de Laranjeiras e Palmeiras.

Concentramos nossas análises sobre estes dois últimos bairros, pois a análise sobre eles mostra mais detalhadamente como estava se processando a desorganização social dos bairros rurais paulistas tendo em vista a proximidade ao centro urbano da cidade de São Paulo. Com relação aos demais, apresentamos apenas algumas conclusões gerais que confirmam a existência da multiplicidade de processos que os estudos sobre bairros rurais podem evidenciar.

Os estudos sobre o bairro da Bacia de Ribeirão das Antas, de pecuária leiteira e localizada entre os municípios de Taubaté e de Redenção da Serra, revelou que mesmo com o processo de industrialização e de urbanização que a cidade de Taubaté apresentava, os bairros rurais sobreviviam sem que o modo de vida de seus habitantes fosse alterado, pois a "Independência e complementaridade, por paradoxal que pareça a sua reunião, constituem os traços característicos do equilíbrio entre os bairros rurais e a cidade". (QUEIROZ: 1973, pág. 28).

Já no município de Leme, cuja cidade na época não apresentava desenvolvimento nem industrialização, verificou-se que as relações econômicas entre essa cidade e o bairro rural de Taquari ocorriam de modo independentes. Esse bairro apresentava uma autonomia para com a cidade, pois as condições econômicas de seus habitantes não dependiam da cidade de Leme, mas ligavamse a um mercado regional e não local. "Do ponto de vista econômico, não se liga à cidade, e sim à economia regional e mesmo estadual; $\{\ldots\} O$ bairro rural tem assim certa autonomia diante da cidade, que decorre tanto da falta de um desenvolvimento desta, quanto do efetivo desenvolvimento econômico dos sitiantes. $\{\ldots\}$ a existência de uma grande cidade não é fator essencial de desenvolvimento para a área rural imediatamente próxima". (Idem, pág. 51).

Sobre os bairros de Itapeva, Campo Redondo e de Bragança, produtores de leite e localizados no sertão do município de Paraibuna, verificou-se que a integração da cidade de Paraibuna para com os bairros rurais era limitada, pois só existia mais intensamente apenas em determinados momentos da vida dos 
habitantes. A distância geográfica entre os bairros e a cidade e a falta de participação dos habitantes agiam como um fator de desagregação social, determinando um convívio esporádico entre os habitantes, que somente ocorreria por ocasião da festa do padroeiro. "A integração destes bairros à cidade é, pois, limitada, existindo com mais força apenas em determinados momentos da vida dos indivíduos. A existência quotidiana se passa quase inteira dentro de um clima de autonomia. O sistema econômico vigente, ao contrario do que habitualmente se pensa e se diz, é o laço mais poderoso de união entre os bairros e a sociedade global". (Ibidem: pág. 85).

\section{1 - O bairro de Laranjeiras}

Este bairro era formado, até o momento do estudo, por cerca de 30 casas, 150 moradores, uma capela, uma venda e uma escola. Os sítios eram distantes um dos outros. Entretanto, com o passar do tempo foram-se formando pequenas unidades em torno da capela, que receberam ora o nome de um acidente geográfico, ora um nome indígena, ora o nome de um santo, ora de uma família, etc.

A produção era mais que suficiente para alimentar as famílias. $O$ excedente era destinado ao mercado de São Paulo, onde era trocado por tecidos, pólvora, sal, vinho e aguardente. Cada sitiante possuía sua tropa de burros e seu contato com São Paulo era contínuo. Os mutirões eram freqüentes e constituíam a maneira pela qual os sitiantes se supriam da mão de obra necessária, quando empreendiam trabalhos mais vastos ou quando uma tarefa era premente. Havia ricos e pobres, mas o modo de vida tradicional não permitia que houvesse diferenças econômicas acentuadas. Todos concorriam em pé de igualdade aos mutirões, embora houvesse algumas famílias com mais tropas ou com uma casa mais guarnecida. Mas, como seus vizinhos, os membros destas famílias trabalhavam todos na roça e não tinham a possibilidade de contratar mão de obra.

Alguns fatores contribuíram para manter esta situação, como as condições do solo, a localização da região, a participação dela nos ciclos econômicos que caracterizaram a economia paulista a partir do final do século 
XVIII: como o cultivo do açúcar; do café e posteriormente a industrialização. Por outro lado, a proximidade da cidade de São Paulo incitava os sitiantes a aumentarem sua área de lavoura, na certeza de encontrar mercado fácil para tudo o que produzissem. A extensão das terras era tal que permitia o uso da técnica de queimadas e a abertura de novas roças quando o cansaço do solo se manifestava; permitia também que as novas famílias dos descendentes abrissem lavouras em sítios ainda não trabalhados, tornando desnecessária a expulsão de membros das famílias por falta de terras.

O trabalho independente possibilitava que os sitiantes se deslocassem para festas, para compras, para visitas e para cumprir um dever religioso. Estes momentos propiciavam aos habitantes uma maior integração social e a consciência da unidade e do funcionamento do bairro.

Entretanto, a situação do bairro de Laranjeiras começa a mudar:

A situação do bairro de Laranjeiras, no Sertão de Itapecerica, por volta de 1935, era a seguinte: o crescimento natural da população multiplicara os moradores e determinava, com o aumento da quantidade de roças (cada família tendo individualmente a sua), uma conseqüente diminuição da área não plantada. As propriedades, que três gerações antes eram muito grandes e permitiam abertura de lavouras em matas virgens, passaram a exigir rodízio de roças; a produção não era mais tão abundante que permitisse por à venda um excedente compensador. Estas circunstâncias vinham se somar ao aparecimento dos concorrentes, produtos comercializados que começavam a vender na cidade de São Paulo. Assim, o nível de vida dos sitiantes não podia mais continuar na mesma altura em que se mantivera no passado. (QUEIROZ, 1973, pág. 96).

Para agravar ainda mais a situação, o desenvolvimento industrial de São Paulo determinava uma maior procura por combustível, lenha e o carvão vegetal, necessários às pequenas empresas artesanais que se multiplicavam rapidamente, demandando cada vez maiores consumos destes combustíveis.

Os sitiantes começaram a aproveitar a madeira derrubada; produziam agora algo que não entrava em competição com os agricultores cerealistas nem com os chacareiros do cinturão verde. Um novo produto comercial, - o 
carvão,- compensava assim de um lado a penúria de excedentes agrícolas; de outro lado a perda do mercado de víveres. Sua exploração permitia outrossim manter o mesmo gênero de vida anterior, a mesma independência no trabalho. O carvão constituiu então uma atividade complementar dos sitiantes. (Idem, pág. 96).

Mas, com o passar do tempo, a produção do carvão passa a se tornar a atividade principal dos sitiantes de Laranjeiras. O surgimento de um novo tipo de forno e a abertura de uma estrada estadual até Juquitiba aumentou ainda mais a possibilidade de lucro fácil. Entretanto, enquanto a produção aumentava essa possibilidade, mas o comércio roubava a autonomia e independência dos sitiantes. Acontece que os sitiantes perderam o contato com os mercados paulistanos quando passaram a entregar o carvão para ser embarcado nos caminhões dos intermediários. "Estes caminhões traziam até Aldeinha as mercadorias de que necessitavam os sitiantes, efetuando-se a troca do carvão por elas". (Ibidem, pág. 96).

Assim, alguns sitiantes deixaram a lavoura para se dedicar exclusivamente à produção do carvão. Muitas terras se esgotaram não havendo mais espaços para novas culturas. Muitos sitiantes passam a deixar sua terra em descanso, enquanto passam a arrendar parcelas de terras, fazendo assim surgir o regime de parceria na região. Como os proprietários das terras abandonadas pararam de pagar impostos, a arrecadação municipal decaiu. E, juntamente com ela, todo nível de vida de Laranjeiras.

E, em 1960, com a abertura da rodovia BR-2 que corta o município, as terras se valorizaram e, como o preço do carvão estava cada vez mais baixo, a solução era vendê-las, obtendo assim, com as prestações da venda, uma melhor condição econômica.

Disso resultou um processo interno de diferenciação social entre os sitiantes. De um lado, os sitiantes vendeiros, aqueles cujos sítios ainda permitiam a exploração da lenha e da produção de carvão, e do outro, os carvoeiros, aqueles que passaram da condição de sitiantes independentes para a de empregados assalariados. Outros, ainda, não puderam mais prosseguir no ritmo tradicional e passaram a vender as terras e passaram a serem empregados assalariados dos 
compradores das terras ou a se tornarem pequenos comerciantes no local, abrindo vendas ou quitandas à beira das estradas.

\section{2 - o bairro de Palmeiras}

Palmeiras era um bairro rural típico, segundo QUEIROZ, apresentando um pequeno aglomerado composto por uma igreja, um escola, uma serraria, três armazéns e cerca de vinte casas, enquanto outras mais se dispersavam desordenadamente pelas cercanias; a rodovia BR-2 que cortava o bairro, ao meio, deformou seu caráter unitário e o deixou a igreja de costas para pra ela; pelo tamanho do núcleo, verificava-se que o bairro estava em expansão.

As casas, em sua maioria, eram de alvenaria, caiadas e cobertas com telhas; não havia rede de água; nem de energia elétrica; as fossas eram construídas próximas das casas; os móveis eram fabricados pelos camponeses, podendo às vezes ser comprados; tinham fogão a gás, além de fogão à lenha e alimentação era na maior parte fornecida pelo que produziam e numa menor parte por mantimentos comprados fora. Somente metade dos habitantes era alfabetizada, sendo a maioria dos alfabetizados com idade de menos de 35 anos.

Os camponeses cultivavam milho, feijão, batata, mandioca e criavam galinhas e porcos e, esporadicamente, alguma vaca; a mão-de-obra era familiar; a produção se destinava ao consumo da família; o excedente era destinado aos mercados de Santo Amaro e Itapecerica; as técnicas de plantio eram rudimentares e não havia a necessidade do uso de adubo e o mutirão era muito utilizado. "Até 1940, a vida econômica dos habitantes de Palmeiras girou em torno de atividades essencialmente agrícolas". (QUEIROZ, 1973, pág. 101).

Mas, a introdução do carvão na região, a partir desta década, provocou nas unidades um processo inicial de excedentes, o que incentivou os muitos camponeses a trocarem a lavoura pelo a produção de carvão. E, posteriormente um processo de desagregação econômica. O carvão era uma produção familiar que não agradava as mulheres por ser trabalho pesado e sujo, muitas vezes. $O$ trabalho da mulher foi estão substituído por um trabalho de camarada. Para a exploração do carvão, utilizaram primeiramente as matas da propriedade e em 
seguida passaram a comprar matas vizinhas ou mais distantes a fim de poder continuar com a exploração. Porém, embora houvesse a entrada rápida de dinheiro a produção de carvão trouxe a miséria à Palmeiras: “\{...\} ninguém mais queria plantar, passou-se a fazer mais carvão do que lavoura; era mais fácil comprar na venda com o dinheiro ganho no carvão”. (Idem: pág. 102).

Com o aumento da produção, os preços do carvão começam a cair aliados à baixa produtividade da terra, forçando a população a procurar nova fonte de renda.

Atualmente, os habitantes de Palmeiras se entregam uma pluralidade de atividades: negócios de terras (pois, com a abertura da estrada, está havendo cada vez mais procura de terras por parte de citadino, e elementos de Palmeiras se tornaram inclusive imobiliários ...); fundações de armazéns (três armazéns novos surgiram nas vizinhanças do núcleo agenciados por gente do bairro); aparecimento de duas olarias; cultivo de frutas para o mercado ou para vender na beira da estrada; parceria, empréstimo de dinheiro a juros ... Os motoristas trabalham ou de maneira independente, - isto é, quem pôde comprar um caminhão, aluga seus serviços para puxar areia e cascalho, transportar carvão; ou então empregado de particulares ou de companhias que estão se instalando na redondeza. (lbidem, pág. 103).

A mudança da lavoura para o carvão trouxe muitas transformações ao bairro de Palmeiras: a igreja deixou de ser um centro de atração, pois a maioria da população deixou de freqüentá-la; os habitantes acostumaram-se a freqüentar as festas de outros bairros, apesar de haver grande participação durante a festa do bairro (festa de Santa Cruz) que ocorria durante o mês de maio; os mutirões deixaram de existir; eram freqüentes ainda as peregrinações para Aparecida e Pirapora, embora quando não havia gente suficiente para alugar um caminhão ou ônibus, ela não ocorria; não havia grupos recreativos e as partidas de futebol foram suspensas após a construção da rodovia, em 1957.

Durante a construção da rodovia Regis Bittencourt, muitos camponeses, que haviam perdido a terra, ao encontrarem oportunidade de trabalho assalariado se proletarizaram: alguns trabalharam como motorista de caminhão; outros foram 
trabalhar em armazéns; a rodovia, ao facilitar o escoamento de certos produtos, como os tijolos, cuja produção se expandiu, permitiu que as atividades de prestação de serviços se ampliassem gerando, dessa forma, empregos assalariados na região.

Estamos diante de um bairro rural que, malgrado a perda de alguns elementos que partiram, se mantém estável, pois aqueles foram compensados por outros de fora que casaram no grupo. A estabilidade do grupo deve-se ao crescimento vegetativo também, embora a impressão que se tenha é de que a quantidade de filhos não é hoje tão grande quanto o que contam os informantes de antigamente. Todavia, o bairro não perde elementos de maneira apreciável, e muitos dos que partem, acabam regressando. (Ibidem, págs. 104/105).

O interessante é que os agricultores, quando a terra não ofereceu mais condições necessárias para viver e quando o carvão baixou de preço, passaram para o setor de serviços sem maiores dificuldades sem que este fato novo desorganizasse a vida do bairro de maneira sensível. Isto porque "Os contactos administrativos, políticos e econômicos que o bairro sempre manteve com o resto da região e com as cidades vizinhas, - isto é, com a sociedade global em que se encontra implantado, - devem ter facilitado a passagem. Assim, embora nem um só elemento do grupo tivesse passado de camponês a agricultor, - talvez devido às dificuldades de crédito, ao desconhecimento de técnicas mais evoluídas, e à dificuldade de competir no mercado com os japoneses, estabelecidos na parte norte do município de Itapecerica, - não houve, ao que parece, alteração sensível no nível de vida e a vinda da estrada, em lugar de trazer desorganização à existência da população, pelo contrário, beneficiou-a”. (Ibidem: pág. 105).

Assim, enquanto os bairros rurais eram organizados sob uma economia tradicional e uma estrutura socialmente igualitária, seus habitantes viviam uma situação de fartura de alimentos, pois a "produção dos sítios era mais do que suficiente para alimentar as famílias; mas também havia excedentes que eram levados até a cidade de São Paulo; a maioria dos habitantes era proprietária de um pedaço de terra"; o trabalho independente permitia aos camponeses dispor da maneira que os conviesse do horário de trabalho, pois "era por eles mesmos 
estabelecido, em função da necessidade econômica, mas também em função de suas concepções sobre as práticas religiosas" e das festas que realizavam para se confraternizarem.

Mas, este gênero de vida que persistiu até a década de 1930, sofreu alterações na medida em que o "desenvolvimento demográfico e industrial da cidade de são Paulo acompanhando o desenvolvimento econômico do Estado todo, deu à capital novos caracteres e desligou-a de sua periferia. A melhoria das comunicações com outros pontos do Estado que não unicamente as zonas cafeeiras, possibilitou o aparecimento de plantadores especializados num ou noutro cereal, que podiam vender na cidade sua produção a preços mais convidativos do que os dos sitiantes. Chácaras foram também se desenvolvendo na periferia, cultivadas por portugueses, espanhóis e japoneses, em regime comercial". (Ibidem, pág. 95).

Desse modo, quando tais estruturas foram quebradas o bairro entrou em decadência. A passagem da roça para a produção do carvão desencadeou a perda de um gênero de vida que supria todas as necessidades dos camponeses e o processo de decadência se instalou no bairro. Enquanto no bairro de Laranjeiras esta perda significou a desorganização das estruturas tradicionais levando os camponeses a uma perda econômica e ao processo de diferenciação econômica; no bairro de Palmeiras, esta perda significou a eliminação de alguns elementos da estrutura social tradicional, inclusive com o surgimento do trabalho assalariado e de uma camada miserável (a dos carvoeiros), mas não se verificou uma total decadência econômica dos camponeses, pois, rapidamente, souberam se adaptar às novas atividades que estavam se implantando no bairro. Esta capacidade de adaptação se traduzia na busca de meios que os camponeses pudessem lançar mão para se contrapor ou se adaptar às novas mudanças.

As roças, agora pequenas parcelas, persistiram com a mesma função de garantir o mínimo vital, mas o emprego é que fornece ao antigo sitiante o rendimento necessário para manter seu nível de vida habitual.

Assim, a partir da desorganização das estruturas tradicionais dos bairros do Sertão de Itapecerica, podemos abstrair cinco grupos sociais que resultaram ao 
fim de todo processo: os carvoeiros, os vendeiros, os assalariados, os proprietários de pequenas propriedades e os vendedores autônomos.

a) os carvoeiros - formavam o grupo de camponeses ex-proprietários que trocaram a lavoura pela produção de carvão. Quando os preços caíram e a terra passou a ser improdutiva, venderam suas terras e se tornaram trabalhadores assalariados nas propriedades do interior dos sertões. Vivendo miseravelmente numa área distante e sob o regime de trabalho assalariado não dispunham mais de tempo e condições para continuar integrados socialmente ao bairro;

b) os vendeiros - formavam o grupo de camponeses que deixaram a lavoura para se dedicarem ao comércio, passando a exercer a função de intermediários. Estes, pouco a pouco se alçaram a um padrão de vida mais elevado, mas não chegaram a formar uma camada economicamente superior, pois tão logo possuíam condições, migravam para a cidade;

c) os assalariados - formavam um grupo constituído por motoristas, trabalhadores rurais e de armazéns que não puderam mais conciliar seu horário às exigências dos patrões, aos quais estavam sujeitos, com o do ritmo das festas religiosas; seu atual trabalho não era mais autônomo e tiveram de abdicar de uma série de atividades que anteriormente formavam o centro de suas vidas;

d) os proprietários de pequenas unidades rurais - estes conseguiram se manter como agricultores, mas com um nível de vida muito baixo; ainda conservam alguns elementos, mas não iam mais à igreja com tanta freqüência; deixaram de realizar muitas festas, se restringido apenas à festa do padroeiro do bairro; deixaram de praticar os mutirões e as relações familiares, de vizinhanças e de compadrio deixaram de ser cultivadas;

e) vendedores autônomos - formavam o grupo de camponeses que empobreceram com a queda do preço do carvão e com a baixa produtividade das terras; venderam suas terras e passaram a ser vendedores de frutas às margens das estradas.

Com base nisso, podemos assim identificar a presença dos seguintes processos sociais: 


\section{Classificação dos Tipos Sociais Segundo o Processo Social}

\begin{tabular}{|l|c|}
\hline \multicolumn{1}{|c|}{ Processo Social } & Tipos \\
\hline Diferenciação & Vendeiro, Autônomos \\
\hline Desintegração & Carvoeiro, \\
& Assalariados \\
\hline Recriação & Pequenos \\
& Proprietários \\
\hline
\end{tabular}

\section{Organizado por Antônio Carlos da Paz Santana}

Os estudos de QUEIROZ nos permitiram, ainda, identificar a existência de três fases no processo de desestruturação econômica dos bairros rurais:

a) a primeira fase - caracteriza-se pela existência de paralelismo e de complementaridade entre a cidade e campo, mas, por parte do camponês há independência; pode viver sem a cidade, mas a cidade não pode viver sem ele;

b) a segunda fase - a economia tradicional do camponês começa a se integrar na economia comercial da cidade. O intermediário é a primeira força de dominação econômica urbana; sua atuação faz a produção camponesa passar, na sociedade capitalista, de uma economia em complementaridade independente, para uma economia em complementaridade subordinada. É nesta fase que a vida sócio-cultural e econômica do camponês se degrada;

c) na terceira fase - a subordinação da produção camponesa ao sistema econômico capitalista é total nesta fase. A conservação do modo de vida tradicional, que é centralizada nos elementos culturais constitutivos do bairro rural, correlaciona-se com a conservação de um tipo determinado de equilíbrio entre a vida camponesa, a vida urbana e a vida regional.

Para nós não há necessariamente uma correlação entre os elementos tradicionais e os novos valores impostos pelo advento da modernidade, pois os novos valores podem ser assimilados parcial ou completamente ou podem ser rejeitados parcial ou completamente. De uma forma ou de outra, não implica necessariamente na perda da identidade camponesa.

Resta saber, então, se a hipótese formulada por QUEIROZ sobre se o desenvolvimento urbano e industrial, liberando a cidade de seu meio rural imediato, mergulha os bairros rurais que a circundam num estado de decadência econômica. 
Como já vimos, no capítulo anterior, há diferentes processos em atuação na agricultura brasileira e no caso dos bairros rurais a realidade não se faz de maneira diferente ${ }^{10}$. Por outro lado, as conclusões de QUEIROZ levaram-nos a admitir o fato de que a hipótese acima pode suscitar um caráter de dupla interpretação: primeiro, ela não se comprova para os bairros rurais que estão localizados próximos aos centros urbanos. Os "Sitiantes que se encontram submetidos a variados centros de atração talvez estejam aptos a se adaptar à mudança social, seja adotando novos modos de agir, seja procurando soluções que lhes parecem viáveis no sentido de conservar seu antigo meio de vida"; segundo, ela se comprova para os bairros rurais que estejam distantes dos centros urbanos cujos agricultores não tendo alternativa a não ser a da subordinação a um único centro seriam impedidos de aumentarem suas possibilidades. Ou onde os "sitiantes $\{\ldots\}$ presos a um único centro de interesses, ver-se-iam condenados à estagnação, por não terem possibilidades de ampliar sua visão e seus conhecimentos; estes não agüentariam, resignados dentro da inércia e da estagnação, a decadência em processo". (Ibidem, pág. 117).

\section{3 - O Bairro Rural de Santo Ângelo}

O bairro de Santo Ângelo está localizado na parte Norte do Distrito Administrativo de Jundiapeba do município de Mogi das Cruzes que, por sua vez, está localizado a Leste da Região Metropolitana de São Paulo acerca de 53 km de distância do marco zero da capital.

A distância entre o centro de Mogi das Cruzes (marco zero) e o centro da vila do Distrito de Jundiapeba é de aproximadamente $14 \mathrm{~km}$, seguindo-se pela estrada Velha São Paulo-Rio (SP 66). Já a distância entre o centro da vila de Jundiapeba e a sede da Associação dos Chacareiros, é de apenas $4 \mathrm{~km}$ pela Estrada das Varinhas.

A entrada para o bairro rural de Santo Ângelo é a mesma para quem vai para o Hospital Dr. Arnaldo Pezzuti Cavalcante (antigo Sanatório Santo Ângelo). A partir da entrada, portanto, será mais $1 \mathrm{~km}$ pela entrada Municipal (não é

\footnotetext{
${ }^{10}$ Isso foi constado por QUEIROZ.
} 
pavimentada) até chegar à sede da Associação dos Chacareiros de Mogi das Cruzes, que se localiza à direita e atrás da Escola Estadual Prof ${ }^{\circ}$ Antônio Batalha.

Conforme o Levantamento Planimétrico efetuado pelo ITESP, em setembro de 2002, o bairro de Santo Ângelo media uma área territorial de 874 hectares de extensão.

O Censo Demográfico, realizado em 2000 pelo IBGE, revelou que a população total do Distrito de Jundiapeba era de 39.073 habitantes, sendo 37.999 vivendo na zona urbana e 1.074 na zona rural. Já o Censo de 1991, revelou que o total da população era de 23.675 habitantes, entre os quais a população urbana era de 21.872 habitantes enquanto que a população rural totalizava 1.803 habitantes.

População do Distrito de Jundiapeba - 1991/2000

\begin{tabular}{|l|c|c|l|l|c|}
\hline \multicolumn{3}{|c|}{ Censo de 1991 } & \multicolumn{3}{c|}{ Censo de 2000 } \\
\hline Pop. Total & Pop. Urbana & Pop. Rural & Pop. Total & Pop. Urbana & Pop. Rural \\
\hline 23.675 & 21.872 & 1.803 & 39.073 & 37.999 & 1.074 \\
\hline
\end{tabular}

Fonte: Censos de 1991 e 2000 do IBGE

Como podemos observar na tabela acima, houve um extraordinário aumento da população absoluta do Distrito entre os anos de 1991 e 2000. Mas, segundo o IBGE, o aumento se restringiu à população urbana que, em 1991, era de 21.872 habitantes passando para 37.999 habitantes, em 2000. Houve um acréscimo de mais 16.127 habitantes, ou seja, em menos de uma década, a população urbana desse Distrito aumentou em mais de $73 \%$.

Há, certamente, um grande equívoco: o aumento verificado na população total do Distrito, não se restringiu apenas à zona urbana, ao contrário, o maior aumento de população, durante a década de 90 , se deu exatamente na população do bairro rural de Santo Ângelo e não na população da vila de Jundiapeba, basta verificar, no mapa dos setores pesquisados, o número de construções que o bairro tinha antes (1991) e depois (2000) ${ }^{11}$.

\footnotetext{
${ }^{11}$ Infelizmente, não nos possível fazermos a transferência dos mapas para esse trabalho.
} 
O Distrito apresentou, para o mesmo período, uma significativa redução da população rural $^{12}$, se considerarmos os números absolutos, isto é, dos 1.803 habitantes, em 1991, e os 1.074, em 2000, temos uma redução de 99 habitantes. Mas, se considerarmos apenas os números percentuais, a redução foi de apenas $5,49 \%$. Do mesmo modo, compreendemos que o fato de se considerar a população do bairro rural de Santo Ângelo como rural, há uma supervalorização na totalização da população urbana do Distrito em detrimento a uma sobrevalorização da população rural.

O bairro rural possui uma centralidade em torno da escola do bairro, pois ao seu redor está localizada a Sede da Associação dos Chacareiros de Mogi das Cruzes; um mini-mercado, que também funciona como bar e ponto de encontro de alguns agricultores que se reúnem ao final das tardes para jogar sinuca enquanto bebem "um trago" ou simplesmente conversarem sobre o dia de trabalho; um bar e restaurante; uma bomboniére e uma das quatro igrejas evangélicas existentes no bairro.

É deste local de onde que sai o ônibus escolar que leva e traz os alunos do Ensino Fundamental ( $5^{\mathrm{a}}$ a $8^{\mathrm{a}}$ séries) para estudar nas escolas do centro da vila de Jundiapeba ou de outros Distritos. É também neste local que os habitantes aguardam os ônibus coletivos que circulam, a cada hora, entre o bairro rural e o centro da cidade ou de outros bairros urbanos de Mogi das Cruzes.

O bairro conta com rede de iluminação elétrica em quase todos os arruamentos (são pequenos taludes construídos nas áreas de várzeas que foram construídos para proteger as culturas e, por terem o nível do solo mais elevados que espaços dedicados à lavoura, acabaram se transformando em caminhos ou "ruas"); mas, ainda não possui sistema de distribuição de água encanada; esgoto; e galerias de águas pluviais; há rede de linhas telefônicas, mas funciona precariamente, ou por falta de investimentos no sistema ou porque é constante o roubo de cabos telefônicos na rede; caso as pessoas necessitem enviar ou

\footnotetext{
${ }^{12}$ O IBGE não considera o bairro rural de Santo Ângelo como rural. A população dele é computada juntamente com a população urbana da vila de Jundiapeba. Apesar, das construções serem quase todas unidades de produção agrícola, o IBGE trata o bairro de Área Urbana Legal.
} 
receber correspondências, deverão locar uma "caixinha" no posto dos Correios na vila de Jundiapeba, pois a Empresa de Correios não presta serviços no bairro.

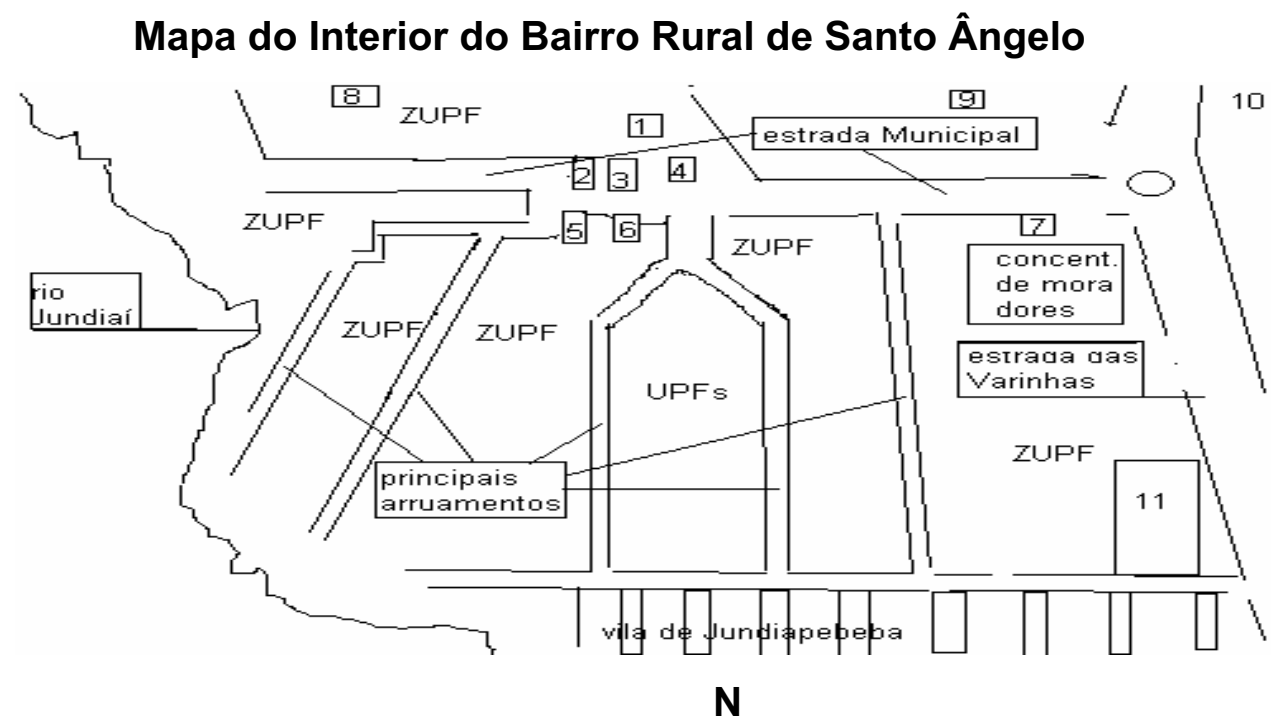

Legenda:

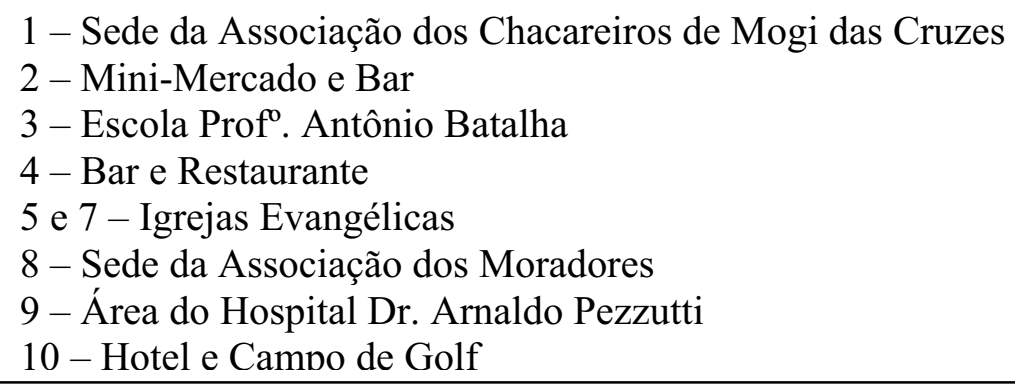

\section{Organizado por Antônio Carlos da Paz Santana}

Não há nenhum posto de atendimento público, municipal, estadual ou federal; a segurança pública é muito precária, se restringindo apenas a eventuais rondas policiais; para os doentes, só há um posto de atendimento que fica no centro da vila de Jundiapeba, há aproximadamente de 5 quilômetros; a única presença do poder público no bairro rural se restringe à escola, que só atende aos estudantes de primeira a quarta série do Ensino Básico, sendo que os demais das outras séries deverão se deslocar para outras escolas do Distrito ou de outros bairros da cidade.

Cortando o bairro, no sentido longitudinal, há uma estrada "Municipal", não pavimentada e que eventualmente recebe algum tipo de manutenção 
(nivelamento), que faz a ligação da estrada das Varinhas (SP 39), a oeste, até o bairro do Conjunto Residencial Santo Ângelo, que se localiza a leste. É por esta estrada "Municipal" que circulam os ônibus coletivos que transportam as pessoas para o centro da vila de Jundiapeba ou da cidade ou para outros bairros de Mogi das Cruzes.

Os agricultores pretendem que a Prefeitura promova a pavimentação asfáltica da estrada municipal por entenderem que o asfaltamento facilitaria a circulação de caminhões no bairro; traria mais comerciantes para a porta das chácaras; facilitaria o escoamento da produção até o mercado do produtor, na cidade de São Paulo; diminuiria os custos com manutenção dos veículos e a produção poderia ser comercializada a um preço melhor.

Os agricultores já realizaram várias visitas à Prefeitura para reivindicar o asfaltamento da estrada. Mas, até agora só conseguiram o nivelamento de alguns arruamentos e a promessa do Assessor do Prefeito, o senhor GILBERTO MORO, de que só seria possível o asfaltamento da estrada durante a segunda gestão do atual Prefeito JUNGI ABE (PSDB).

Além desta estrada, que desempenha uma espécie de "rua principal" do bairro, há vários arruamentos que começam sempre na estrada "Municipal" e terminam próximo às margens do rio Jundiaí, como se esta fosse uma "artéria" que tem a função de irrigar todo o organismo. Eles não têm reconhecimento público, isto é, não existem legalmente; nenhum tipo de calçamento ou pavimentação; rede subterrânea de água; de esgoto; de águas pluviais, mas todos têm nomes. Geralmente, recebem denominações de acordo com o sobrenome do agricultor mais antigo ou a indicação do adjetivo de naturalidade do grupo de agricultores que possuem lotes em torno deles ou de algum acidente geográfico ou de alguma indicação física, como por exemplo: rua Yoshida I, Estrada do Suzuky, rua dos Baianos, rua Manoel Lisboa, rua das Torres (torre de eletrificação que corta o bairro de norte a sul), etc.

O município de Mogi das Cruzes (localizado a leste da Região Metropolitana) está organizado administrativamente em sete Distritos: a Sede e os 
distritos de Biritiba Ussú, Brás Cubas, Cezar de Souza, Quatinga, Taiaçupeba e Jundiapeba.

É neste último, onde se localiza o bairro de Santo Ângelo, que foi criado em 30 de setembro de 1938, através da Lei Municipal 9775, e encontra-se localizado no extremo oeste do município; limitando-se ao norte com o distrito Sede através do rio Tietê; e ao sul, com Quatinga; a leste, com Braz Cubas, através do rio Jundiaí; e a sudeste com os Distritos de Taiaçupeba e Biritiba Ussú, através da represa do rio Jundiaí e faz fronteira, a oeste, com o município de Suzano, através do rio e da represa Taiaçupeba.

QUEIROZ (1973), identificou cinco elementos culturais comuns aos bairros rurais, quais sejam: o sentimento de localidade; a existência da capela; o auxílio mútuo; o trabalho e a autonomia familiar. Tais elementos são identificados em Santo Ângelo, embora apresentem modificações em vista da sociedade atual.

Estes elementos eram constitutivos dos bairros rurais paulistas, na década de 1960. Entretanto, no processo de desestruturação econômica, já era verificado na década seguinte. QUEIROZ afirma que na fase de subordinação da produção ao sistema econômico capitalista, os camponeses conservariam o modo de vida correlacionando-se com a conservação de um tipo determinado de equilíbrio entre a vida camponesa, a vida urbana e a vida regional.

CÂNDIDO (1971), entretanto, considera que todas as vezes que os grupos se encontram na presença de novos valores podem ocorrer três situações: os valores novos são rejeitados, e os antigos mantidos na íntegra; os valores novos são aceitos em bloco, e os antigos rejeitados; os valores antigos se combinam aos novos em proporções variáveis. O bairro de Santo Ângelo, como veremos, apresenta especificamente uma combinação de valores antigos com os da sociedade atual. Entretanto, verificamos a existência de certas particularidades, que não foram mencionadas ou não identificadas por QUEIROZ em seu estudo; mas, da mesma forma, nem todos os elementos culturais comuns aos bairros rurais paulistas, apontados por ela, já podem ainda ser identificáveis em Santo Ângelo, haja vista o processo de adaptação cultural que as famílias estão experimentando. 


\section{1 - 0 processo de ocupação}

Ao procuramos saber sobre a história de ocupação do bairro, fomos informados pelos agricultores de que os primeiros ocupantes não encontraram resistência para entrar nas terras. Os informantes supõem que a Santa Casa de Misericórdia de São Paulo não teria dado maior importância às terras, que são de sua propriedade, após a construção de um Sanatório (atualmente Hospital Arnaldo Pezzuti), cuja área foi doada ao Governo do Estado de São Paulo para que nela fosse construído o tal sanatório.

Ora, como se sabe era muito comum a receita de terapias à base do cultivo de hortas para os doentes portadores de lepra. Estes, geralmente, eram encaminhados para hospitais construídos longe dos centros urbanos, exclusivamente, para atender a este tipo de doentes. É muito provável, portanto, que o cultivo de hortaliças, no bairro de Santo Ângelo, tenha tido este aspecto inicial.

Não é muito difícil encontrar agricultores que ocupam a área há vinte ou trinta anos, entretanto, a maioria dos posseiros atuais é ocupante há oito ou dez anos, um pouco antes da criação da Associação que se deu em 1997.

Os primeiros posseiros teriam sido agricultores descendentes de famílias japonesas. Segundo o senhor TAKASHI ${ }^{13}$, os primeiros agricultores começaram a ocupar as várzeas do rio Jundiaí por volta de 1950/60, sem pagar nenhuma renda. Naquela época, as propriedades eram maiores, pouco numerosas e não havia muita concorrência entre os agricultores.

Entretanto, o aparecimento de várias chácaras, em torno do hospital, acabou despertando o interesse da proprietária que passou a elaborar contratos para providenciar a cobrança da renda da terra.

Mas, na época do início do Plano Real, quando a região passou a receber muitas famílias de migrantes, alguns agricultores antigos residentes, que já pagavam arrendamento, aproveitaram o término do contrato e resolveram repassar a posse.

\footnotetext{
${ }^{13}$ Cf. nossa entrevista, em 22/07/2005. O senhor TAKASHI NAKAGAWA é o atual Secretário de Agronegócio da cidade de Mogi das Cruzes.
} 
Assim, com algum dinheiro conseguido pela transferência da posse (luva), alguns se mudaram para outras áreas, outros resolveram mudar de atividade, passando de agricultores para comerciantes de pequenos estabelecimentos de alimentos no próprio Distrito, ou emigraram para o Japão. Entretanto, muitos agricultores estavam envolvidos em problemas judiciais, pelo não pagamento da renda, e simplesmente deixaram as terras ou passaram a posse (a luva) para outro por qualquer valor.

Ao que tudo indica, os primeiros ocupantes, por não possuírem a posse legal das terras e estarem devendo à Santa Casa, temiam a perda das mesmas e resolveram transferir a posse (a luva) para as famílias recém-chegadas a qualquer preço, ou simplesmente largaram as terras.

Algumas das famílias de origem japonesa teriam acumulado recursos devido aos elevados preços das hortaliças, do aumento do consumo de alimentos por parte da população e dos baixos custos dos insumos, verificados durante a implantação do Plano Real. Ou por meio da transferência da posse das terras para agricultores provenientes do sul, do nordeste ou de outras regiões do Estado de São Paulo, que puderam pagar pelas terras ou, ainda, através da meação ou arrendamento para outras famílias migrantes.

Segundo o Sr. Wilson, alguns poucos agricultores do grupo dos primeiros ocupantes ainda estão vivendo no bairro rural. Mas, a maioria das famílias descendentes de japoneses, deixou a localidade para adquirir terras mais baratas e desembaraçadas em outros Distritos, como o de Cocuera e o de Taiaçupeba.

Assim, centenas de famílias nordestinas de origem pobre conseguiram ocupar a maior parte das terras. Muitas destas famílias e também das sulistas, antes de obter a posse de algum lote, trabalharam como parceiros e, somente após um período de 3 a 4 anos, é que conseguiram adquirir a posse, sempre de minúsculo lote.

Os atuais grupos majoritários de agricultores são de famílias que migraram das Regiões Nordeste e Sul, embora se encontrem, também, famílias originárias dos estados das Regiões Sudeste e Centro-Oeste.

Entre os grupos majoritários, o mais numeroso é o de famílias nordestinas, especialmente da mesorregião do Agreste pernambucano, sendo oriundos principalmente dos municípios de Águas Belas, Barra do Una e Pedra. 
As famílias se estabeleceram (há quase 12 anos), inicialmente, como posseiras ou parceiras de agricultores japoneses, que detinham a posse de uma grande área e residiam na cidade, necessitando ter uma ou mais famílias morando na terra para que sua posse fosse assegurada, em vista do grande número de migrantes que se estabelecia no bairro. Outros nordestinos se instalaram na área como trabalhadores permanentes ou temporários ou simplesmente como moradores. Eles estão concentrados nas áreas mais baixas das várzeas; ocupam os menores lotes; são em sua maioria analfabetos e de mais baixa condição econômica entre os agricultores.

Numa entrevista com um agricultor nordestino, o senhor MENININHO ${ }^{14}$, ele nos informou que deixou sua família (mãe, uma irmã e um irmão), que é proprietária de um pequeno sítio em Águas Belas, sertão de Pernambuco, onde planta feijão, milho, algodão e frutas e cria animais como jumentos, galinhas, ovelhas e porcos, por volta de 1993. Saiu de casa juntamente com um irmão mais novo, e migrou para a cidade de Arujá, estado de São Paulo, para trabalhar como assalariado no corte de pedras numa mineradora a convite de um conterrâneo, que já trabalhava na empresa há aproximadamente seis anos. Após alguns anos de trabalho sem conseguir juntar dinheiro, resolveu migrar com o irmão para Jundiapeba, onde começaram a trabalhar como meeiros.

Hoje, o seu MENINHINHO mora com sua família (a esposa, uma filha e um filho) numa casa simples (a construção é de alvenaria coberta com telhas de amianto, tem quatro cômodos, geladeira, televisão, fogão a gás, aparelho de som etc). Ele tem com o seu irmão a posse de dois pequenos lotes de terra no bairro, onde plantam hortaliças para venderem no mercado do produtor na cidade de São Paulo. Perguntamos se eles ajudam aos familiares que se encontram em Águas Belas e ele nos disse que antes ajudava mais, mas que hoje só eventualmente quando alguém de lá solicita.

Os sulistas formam o segundo grupo majoritário e estabeleceram-se há quase 14 anos na área, sendo formado quase que exclusivamente por gaúchos e

\footnotetext{
${ }^{14}$ Senhor ROBERVAL TENÓRIO DOS SANTOS. As entrevistas foram realizadas entre janeiro e julho de 2004.
} 
paranaenses. Os que chegaram com algum recurso compraram dos agricultores japoneses a posse (luva) de um ou mais pequenos lotes. Mas, a maioria teve que, inicialmente, trabalhar como parceiro para que, depois de alguns anos economizando, pudesse conseguir comprar a posse da terra. Eles estão concentrados nas áreas mais altas das várzeas ou nas encostas.

Numa entrevista ${ }^{15}$ com um agricultor gaúcho, o senhor LOURENÇO, ele nos contou um pouco de sua história: disse que sua família possuía terras no Estado do Rio Grande do Sul, no município de Marau, mas resolveu vendê-las para comprar uma propriedade maior no norte do Paraná, há 40 anos - "muita gente de lá foi pro Paraná abrir terras". Mas, com a chegada de milhares de famílias, logo as áreas de fronteira se esgotaram - "acabou com o Paraná todo, aí não tinha mais lugar". Entretanto, os investimentos não foram bem sucedidos, pois, não havia mercado consumidor e a família migrou novamente, depois de poucos anos, para o Estado do Mato Grosso do Sul. Lá, o senhor LOURENÇO foi empregado de uma família que tinha um armazém e uma concessionária de tratores, enquanto sua família continuava trabalhando na agricultura. Após anos de trabalho e de fracassos nos Estados do Paraná e Mato Grosso do Sul, ele resolveu deixar a família e, junto com dois outros primos, migrou para Jundiapeba, incentivado pelo o senhor CLAUDINO, que já havia se instalado no bairro. Com o dinheiro que eles trouxeram, compraram a posse de uma área de 10 hectares "pelo preço de hoje equivale a $R \$ 25$ ou 30 mil" - e passaram a trabalhar em parceria. Com o primeiro lucro, ele comprou individualmente um outro lote - "a primeira coisa que fiz aqui foi comprar uma terra" - e, com o segundo, uma casa "a segunda coisa que fiz, comprei uma casa pra mim morar". Vê-se que a produção de verduras era bastante lucrativa na época - "a outra turma que ta hoje pobre é porque chegou e a primeira coisa que fez foi comprar carro, aí só festa e depois trabalhava mais um pouco". A chegada do senhor LOURENÇO ao bairro, deu-se por volta de 1994/5, período em que o Plano Real estava sendo implantado. Este período, de um ou dois anos que precede à implantação da moeda do Real, é o período que os agricultores consideram bom e se referem a

${ }^{15}$ O senhor LOURENÇO nos concedeu esta entrevista em sua casa, na chácara, no dia 09/07/2004. 
ele como "quando o preço das hortaliças era bom" ou simplesmente de "quando dava".

Hoje, o senhor LOURENÇO possui uma área de 40 hectares de terras. Nela, ele organiza a produção com os seus três meeiros, segundo um sistema particular de cultivo: cada um é responsável pela produção de uma ou mais determinadas culturas, ou seja, enquanto o senhor LOURENÇO planta somente ervas, um meeiro planta salsa e brócolis, outro coentro e alface e outro repolho, espinafre, rúcula e couve. Percebe-se uma preocupação em produzir cultivos que os outros agricultores do bairro não plantam: - "depois cada um plantava uma coisinha que ninguém tem". Perguntamos porque trabalhava com meeiros e não com empregados e ele nos disse "não consigo tocar isso aqui com empregado, mas nem ferrando". Justificou a sua escolha dizendo que o empregado faz tudo errado por má vontade: "eu fico louco e não toco; a chácara é mais difícil de tocar que uma fazenda ou uma concessionária porque assim você planta todo dia e colhe todo dia. Aí tem época que você tem de plantar mais fundo mais por cima, menos sementes outra vezes menos sementes, se falar pro empregado joga semente, ele joga demais, e se falar jogar pouca semente, ele joga pouco demais e você acaba ficando louco". Disse ainda que o meeiro trabalha certo e não pára nenhum dia para o descanso, nem mesmo nos feriados - "os meeiros nem sabe que é feriado hoje, nem sabe que feriado foi hoje, eles trabalham pra eles".

Seu desejo é o de expandir a produção com mais terras, mas afirma que não teria condições porque, além do trabalho na chácara ser pesado e sua família ser pequena (a esposa cuida das atividades domésticas; o casal tem uma filha pequena e o senhor LOURENÇO tem um filho mais velho, fruto do primeiro casamento, que é estudante universitário e não trabalha), não encontraria mão-deobra qualificada para empregar. "Aqui é difícil, chácara é difícil você crescer bastante $\{. .$.$\} . Por exemplo, eu poderia crescer mais, mas não tem como \{pausa\}$ aí se você tiver uma família grande dá, mas também é mão de homi. Igual eu te falei, você tem que plantar e colher, o adubo é caro, a semente é cara".

A sua propriedade está localizada nas encostas, onde o solo não é tão fértil e úmido como ocorre nas várzeas, demandando assim o uso de um aparato 
agrícola compatível. Ele adquiriu recentemente um trator novo e divide o seu uso, bem como o dos implementos agrícolas, do equipamento de irrigação, além do consumo de insumos agrícolas e da eletricidade, com os seus meeiros, que assumem, igualmente, as despesas provenientes do uso de todo material.

Ele é o agricultor de maiores posses na localidade. Além de possuir a posse do maior lote do bairro, é também proprietário de duas casas, sendo uma na cidade, munida de modernos eletrodomésticos, e a outra no bairro rural. Tem um trator, um caminhão e dois automóveis de passeio. Ele nos informou que a produção das terras, incluindo a produção dos meeiros, atualmente gera uma renda diária de $R \$ 500,00$ exceto aos domingos e segundas-feira, quando não há a realização de entregas.

\section{2 - A Ameaça às áreas de proteção aos mananciais}

O município de Mogi das Cruzes, que possui a maior área da região do Alto Tietê e a segunda da região da Grande São Paulo, tem uma parte significativa dela destinada à proteção de mananciais: a área territorial total do município é de $721 \mathrm{~km}^{2}$ sendo a metade (49\%) destinada, por lei, à proteção aos mananciais. $\mathrm{O}$ elevado percentual destinado à preservação deve-se ao fato de a área do município compreender uma grande parte da bacia hidrográfica do Alto Tietê, um dos principais abastecedouros de águas fluviais da RMSP.

As áreas de mananciais são protegidas por lei, havendo um maior controle por parte dos órgãos públicos em relação á sua ocupação. Deste modo, observa-se forte pressão sobre as áreas agrícolas localizadas junto às áreas urbanizadas, fato relacionado à especulação imobiliária gerada pelo crescimento urbano. Este é certamente um grande desafio que os agricultores dos municípios da microrregião do Alto do Tietê estão tendo de enfrentar. A tabela abaixo, mostra como estão atualmente distribuídas as áreas quanto ao uso e ocupação dos solos neste município. Verifica-se que o tamanho das áreas destinadas à preservação ambiental atinge um elevado índice percentual: 49\% quase a metade de todo o território do município. 
Uso do solo - município de Mogi das Cruzes

\begin{tabular}{|c|c|c|c|c|c|c|c|}
\hline \multicolumn{2}{|c|}{ De uso natural } & \multicolumn{2}{|c|}{ De uso Rural } & \multicolumn{2}{|c|}{ De uso urbano } & \multicolumn{2}{|c|}{ Total do município } \\
\hline $\mathrm{Em} \mathrm{km}^{2}$ & Em \% & $\mathrm{Em} \mathrm{km}^{2}$ & Em \% & $\mathrm{Em} \mathrm{km}^{2}$ & Em \% & $\mathrm{Em} \mathrm{km}^{2}$ & Em \% \\
\hline 353,29 & 49 & 273,98 & $38 \%$ & 93.73 & $13 \%$ & 721,0 & 100,0 \\
\hline
\end{tabular}

Fonte: Sumário de dados de Mogi das Cruzes - Prefeitura Municipal-1999

As unidades de produção agrícola, localizadas nesta microrregião, estão submetidas a uma forte pressão de deslocamento causada pelo progressivo crescimento urbano de toda região metropolitana de São Paulo. A expansão das cidades, onde o mercado de terras atua impunemente, e o deslocamento de unidades agrícolas para outras áreas nesta microrregião ameaçam cada vez mais as áreas de proteção ambiental e de mananciais, tornando premente a adoção de medidas que regulamentem a ocupação e uso do solo.

Mas, essas medidas não podem promover simplesmente a eliminação das unidades agrícolas, nem o deslocamento para áreas onde os solos não sejam compatíveis com a produção de hortaliças ou distantes dos mercados consumidores, sob pena do elevado custo social que se obterá com a migração das famílias em direção aos centros urbanos já tão populosos e profundamente marcados por desigualdades sociais.

MARQUES (2004) adverte que "a profunda desigualdade que marca a nossa sociedade não se reduz à sua dimensão econômica e, por isso, não pode ser tratada como sinônimo de carências materiais. Reflete uma sociedade segmentada, estratificada, na qual boa parte de seus membros é concebida e tratada como "cidadãos de segunda classe", ou mesmo "incivil", não se constituindo cidadãos de direito". (Pág. 39).

Dos $721 \mathrm{~km}^{2}$ de extensão retirando-se os $49 \%$ que são destinados à conservação e preservação ambiental chega-se o total de $353,2 \mathrm{~km}^{2}$, ou seja, quase 1,3 maior que a área destinada ao uso agrícola $\left(273,2 \mathrm{~km}^{2}\right)$ e quase 3,8 vezes maior que a de uso urbano $\left(94,5 \mathrm{~km}^{2}\right)$.

DOS SANTOS (2001) considera que a porcentagem correspondente às áreas protegidas no município de Mogi das Cruzes, por legislação estadual e 
municipal, alcance $79 \%$ do território, sendo $49 \%$ referentes à proteção dos mananciais. Em seu trabalho sobre as infrações ambientais cometidas em Mogi das Cruzes, ele apresenta um quadro que sintetiza as áreas protegidas e a respectiva legislação que atua sobre cada uma delas, o qual reproduzimos abaixo:

Áreas Protegidas do Município de Mogi das Cruzes

\begin{tabular}{|c|c|c|c|}
\hline LOCAL & INST. JURÍDICA & ATO JURÍDICO & ÁREAS (há) \\
\hline \multirow[t]{3}{*}{$\begin{array}{l}\text { Serra do } \\
\text { Itapeti }\end{array}$} & Estação Ecológica & $\begin{array}{c}\text { Decreto Estadual } \\
26.890 / 87\end{array}$ & 89 \\
\hline & Parque Municipal & Lei Municipal 1.955/70 & 352 \\
\hline & $\begin{array}{c}\text { Áreas de Proteção } \\
\text { Ambiental }\end{array}$ & Lei Municipal 3.386/88 & 5.047 \\
\hline \multirow[t]{2}{*}{ Serra do Mar } & Parque Estadual & $\begin{array}{c}\text { Decreto Estadual } \\
10.251 / 77\end{array}$ & 3,38 \\
\hline & Área Natural Tombada & $\begin{array}{c}\text { Resolução } \\
\text { CONDEPHAAT 40/85 }\end{array}$ & 4.013 \\
\hline $\begin{array}{l}\text { Várzea do } \\
\text { Rio Tietê }\end{array}$ & $\begin{array}{l}\text { Área de Proteção } \\
\text { Ambiental }\end{array}$ & Lei Estadual 5.598/87 & 11.801 \\
\hline $\begin{array}{l}\text { Vale do } \\
\text { Butujuru. }\end{array}$ & $\begin{array}{l}\text { Área de Proteção } \\
\text { Ambiental }\end{array}$ & Lei Municipal 2.257/77 & 5.715 \\
\hline \multirow[t]{4}{*}{$\begin{array}{l}\text { Bacias dos } \\
\text { Mananciais }\end{array}$} & $\begin{array}{l}\text { Área de Proteção aos } \\
\text { Mananciais }\end{array}$ & $\begin{array}{l}\text { Lei Estadual 898/75 } \\
\text { Lei Estadual 1.172/76 }\end{array}$ & \multirow[b]{4}{*}{35.800} \\
\hline & & Lei Estadual 2.177/79 & \\
\hline & & Lei Estadual 3.286/82 & \\
\hline & & Lei Estadual 3.746/83 & \\
\hline \multicolumn{2}{|l|}{ Total } & \multicolumn{2}{|c|}{$62.820,38$} \\
\hline
\end{tabular}

Fonte: DOS SANTOS, R. C. 2001, pág. 62

Para coordenar a aplicação da Legislação Ambiental, foi criada, em 1986, a Secretaria de Estado do Meio Ambiente de São Paulo como um instrumento de coordenação, de âmbito estadual, que "visa integrar diferentes instrumentos para a correção e a prevenção da degradação ambiental mediante processos de 
parcerias entre o Estado, as Prefeituras, as organizações não governamentais, os institutos de pesquisa, as entidades educacionais e a sociedade civil em geral". Esta Secretaria, portanto, integra as atividades de cinco Coordenadorias: a CINP _ Coordenadoria de Informações Técnicas, Documentação e Pesquisa Ambiental; a CEAM - Coordenadoria de Educação ambiental a CPLA - Coordenadoria de Planejamento Ambiental; a CPRN - Coordenadoria de Licenciamento Ambiental e de Proteção de Recursos Naturais e a CCOM - Coordenadoria de Comunicação. Além destas coordenadorias, também são vinculadas à Secretaria: a CETESB Companhia de Tecnologia de Saneamento Ambiental; a agência ambiental do Estado e a Fundação florestal. (Cf. DOS SANTOS, 2001, pág. 76 e 77).

As áreas de preservação ambiental e dos mananciais são cobertas pela Divisão Regional Metropolitana de São Paulo (DRMSP). Esta Divisão, "formada por sete equipes Técnicas, é a responsável pelo licenciamento e fiscalização dos 39 municípios que fazem parte da Região Metropolitana da Grande são Paulo, unidade política-administrativa com $8.051 \mathrm{~km}^{2}, 16,6$ milhões de habitantes e 48,6\% da população do Estado de São Paulo". (Cf. DOS SANTOS, 2001, pág. 84).

Por outro lado, segundo o SINDICATO DOS PRODUTORES RURAIS DE MOGI DAS CRUZES (1997), só no município de Mogi das Cruzes são aproximadamente 2.000 famílias de produtores, podendo chegar ao total de 4.000 famílias considerando as demais famílias dos demais municípios da microrregião. Se se considerar que as famílias brasileiras, atualmente, são compostas por quatro indivíduos, temos, então, um número significativo de cerca de oito mil pessoas que dependem diretamente da produção agrícola, sem contar o número de famílias que dependem indiretamente, tais como: às dos empregados temporários e permanentes; dos atravessadores; dos comerciantes, dos motoristas, etc.

A Equipe Técnica de Mogi das Cruzes é responsável pela fiscalização das áreas de 11 municípios que, exceto Arujá, Guarulhos e Santa Izabel, integram a microrregião do Alto do Tietê. A tabela abaixo mostra que quatro dos oito municípios que integram esta microrregião têm um alto percentual de seu território destinado à preservação ambiental e aos mananciais: 
Área territorial, distância da capital e porcentagem da área de proteção aos mananciais por municípios da microrregião do Alto Tietê.

\begin{tabular}{|c|c|c|rr|}
\hline Município (D.E) & $\begin{array}{c}\text { Área } \\
\text { Total } \\
\left(\mathbf{k m}^{2}\right)\end{array}$ & $\begin{array}{c}\text { Distância da } \\
\text { capital em } \\
(\mathbf{k m})^{2}\end{array}$ & $\begin{array}{c}\text { Porcentagem da área } \\
\text { destinada à proteção de } \\
\text { mananciais }-\left(\mathbf{k m}^{2}\right)\end{array}$ \\
\hline Biritiba Mirim (1964) & 414 & 72 & 368,46 & $(89 \%)$ \\
\hline F. de Vasconcelos (1954) & 25 & 32 & 5,75 & $(23 \%)$ \\
\hline Guararema (1898) & 262 & 75 & 0,00 & $(0,0 \%)$ \\
\hline Itaquaquecetuba (1954) & 83 & 31 & 0,00 & $(0,0 \%)$ \\
\hline Mogi das Cruzes (1611) & 721 & 53 & 353,24 & $(49 \%)$ \\
\hline Poá (1948) & 17 & 30 & 0,34 & $(2,0 \%)$ \\
\hline Salesópolis (1857) & 418 & 96 & 409,64 & $(98 \%)$ \\
\hline Suzano (1948) & 195 & 38 & 135,05 & $(73 \%)$ \\
\hline Alto do Tietê & 2.135 & - & 272,53 & $(50 \%)$ \\
\hline
\end{tabular}

Fonte: Prefeituras Municipais e Seade - (1 - Data de emancipação política do município; 2 - A partir do marco zero da capital).

Segundo DOS SANTOS (2001), as Equipes Técnicas operam a fiscalização a partir de 19 tipos diferentes de infrações: a supressão da vegetação fora de preservação permanente - maciço florestal; fora de preservação - árvores isoladas; em preservação permanente - maciço florestal; em preservação permanente - árvores isoladas; em reserva averbada - maciço florestal; em reserva averbada - árvores isoladas; dificultar a regeneração em área de preservação permanente; abrir canais, desviar curso d'água, executar barragens; causar poluição que provoque a mortalidade de animais; utilizar, perseguir e destruir animais silvestres; caçar animais da fauna silvestre; comercializar espécimes da fauna ou produtos e objetos ligados à caça; introduzir espécimes da fauna exótica; transportar animais entre estados; utilizar, receber, armazenar ou transportar produtos da flora; suprimir vegetação em unidade de conservação; executar movimentação de terra em área de preservação ambiental e cortar árvores declaradas patrimônio ambiental.

Para o atendimento da demanda de licenciamento e fiscalização, a Equipe Técnica conta com três funcionários e com um grupo de trinta e oito policiais do $3^{\circ}$ Pelotão da $1^{a}$ Companhia do $1^{\circ}$ Batalhão da Polícia Florestal e de Mananciais. Do trabalho realizado sobre a fiscalização, entre 01 de março de 1990 até o mês de novembro de 1999, "a Equipe Técnica de Mogi das Cruzes lavrou 2.986 (dois mil, novecentos e oitenta e seis) multas em todos os municípios de sua responsabilidade. Apenas no município de Mogi das Cruzes foram lavradas 686 
(seiscentos e oitenta e seis) multas, ${ }^{16}$ sendo $59 \%$ referentes à supressão de vegetação em área de preservação permanente". (Idem, pág. 93).

Se tomarmos o bairro rural de Santo Ângelo como exemplo, teremos a seguinte situação: a área total do distrito de Jundiapeba é de 50 km² $(5.000$ hectares), compreendendo áreas urbana, rural e de preservação aos mananciais. Excluindo-se os demais bairros rurais, os agricultores e os moradores do bairro rural chácaras de Santo Ângelo (num total de máximo de 5 mil pessoas) ocupam, juntos, uma área de 874 hectares, ou seja, 17,5\% apenas do total da área de todo município. Mas, o exemplo melhor está no fato de que a área efetivamente ocupada, com lavouras e moradias, é de apenas 684 hectares, ou seja, 78,2\% da área do bairro. A diferença entre o total da área do bairro e a área efetivamente ocupada é de 190 hectares, portanto, são $21,8 \%$ da área que se destinam à proteção ambiental e conservação aos mananciais.

Assim, se por um lado, a análise dos dados nos remetem a um paradoxo, cuja resolução deve partir da premissa de que há espaços territoriais no município suficientes para todos os tipos de usos do solo, urbano, rural e preservação e conservação natural, e do bom senso de todos os envolvidos (técnicos de órgãos públicos, associação e sindicatos de agricultores, de trabalhadores rurais, urbanistas, sociólogos, geógrafos etc.) para com a questão; por outro, compreendemos também, que o estudo de um projeto, adaptado à realidade do município e alternativo ao planejamento urbano-economicista, deverá estar orientado segundo três princípios básicos constantes na Lei Orgânica municipal:

(I) "Todos têm direito de desfrutar de um meio ambiente ecologicamente equilibrado, bem de uso comum do povo e essencial à sadia qualidade de vida, ${ }^{17}$ impondo-se ao Poder Público e à população o dever de defendê-lo e preservá-lo";

(II) "Caberá ao Município, com a cooperação do Estado e da União orientar e estimular o desenvolvimento rural ${ }^{18}$, visando ao aumento da produção e da produtividade, bem como propiciar benefícios ao

\footnotetext{
${ }^{16}$ Grifo nosso.

${ }^{17}$ Grifo nosso.

${ }^{18}$ Idem.
} 
produtor e ao trabalhador rural, objetivando ofertas adequadas de alimentos à população local" e,

(III) proporcionar meios adequados à fixação do produtor e do trabalhador rural no campo ${ }^{19}{ }^{2}$ promovendo os melhoramentos públicos necessários “. (Lei Orgânica do município de Mogi das Cruzes: 2005, Artigos 144 e 169).

\section{3 - Descrição das áreas: Títulos 1 e 2}

O bairro rural tem 684 hectares de área destinada ao cultivo, sendo divididas em duas partes que os agricultores denominam Título 1 e Título 2.

A diretoria da Associação dos Chacareiros estima que haja 585 agricultores associados, sendo que desse total 421 agricultores declararam possuir chácara na parte do Título 1 e 164 agricultores declararam possuir chácara na parte do Título 2. Na verdade, a listagem utilizada para se fazer à contagem está há muito tempo defasada. A maior parte dos associados, constantes na listagem, está em situação de inadimplência, porque parou de pagar a mensalidade (atualmente ao valor de $\mathrm{R} \$ 20,00$ ) ou porque vendeu a posse (a luva) ou porque simplesmente largou ao abandono.

O Título 01 corresponde à área que constitui a maior parte das terras do bairro rural, medindo 491,92 hectares de extensão. É a área de maior concentração de agricultores (421), está legalmente desembaraçada e a Santa Casa de Misericórdia de São Paulo é a legítima proprietária. Possivelmente, esta parte do bairro rural foi a primeira a ser ocupada pelos atuais agricultores. Os 421 agricultores em sua maioria, não pagam o arrendamento pelo uso da terra, apesar de reconhecerem que esta parte das terras pertence legalmente à Santa Casa.

\footnotetext{
${ }^{19}$ Idem.
} 


\section{Mapa da localização do bairro de Santo Ângelo no Distrito de Jundiapeba}

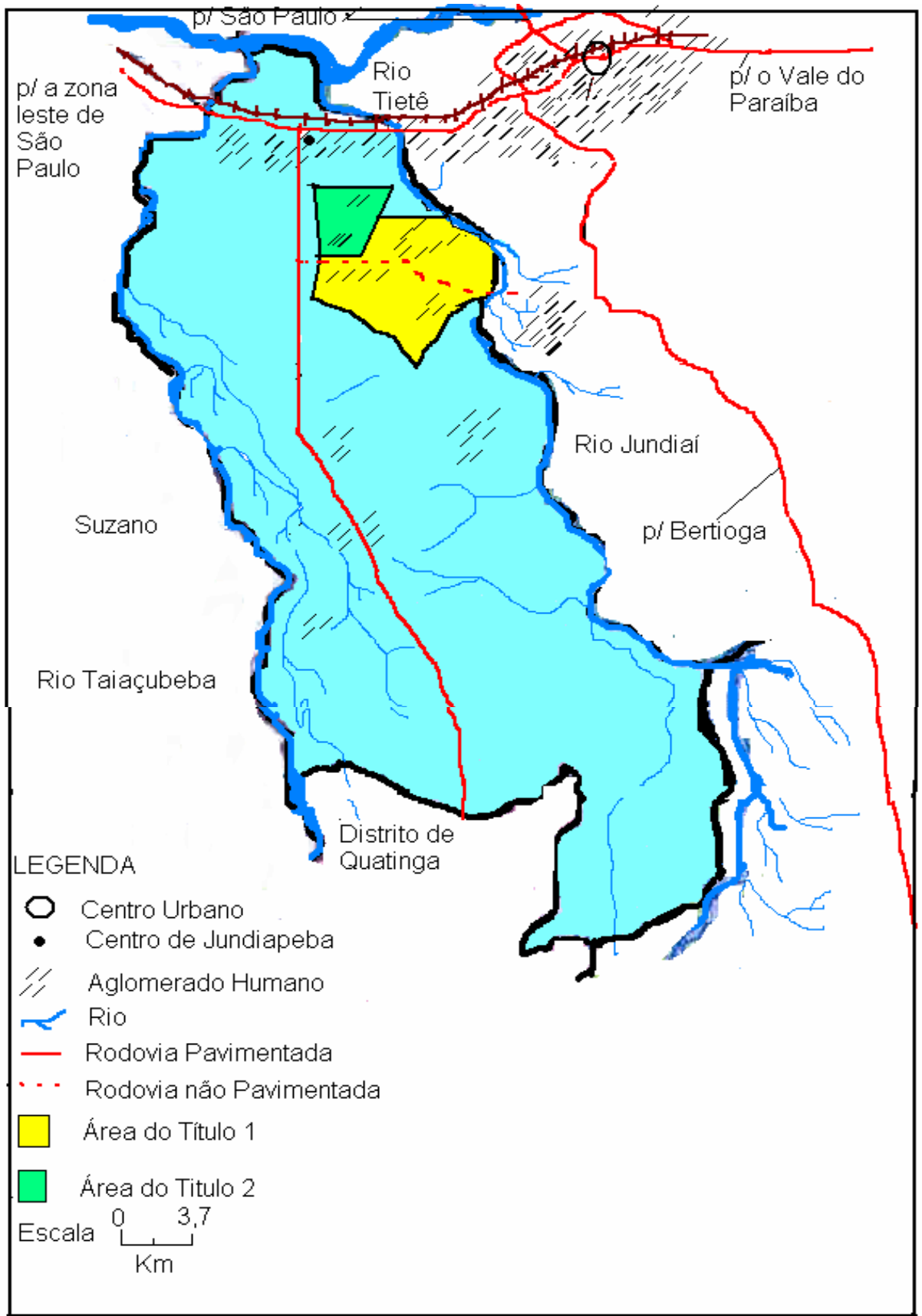

Organizado por Antônio Carlos da Paz Santana

Segundo o Dr. ZAMBOTTO, advogado contratado pela Associação dos Chacareiros, os contratos de arrendamento estavam irregulares, por conterem uma cláusula que obrigava os agricultores a doar para a Santa Casa as 
benfeitorias que eles construíram quando os contratos fossem encerrados, sendo, portanto, passíveis de ato de anulatório.

Mas, havia outras irregularidades: somente aproximadamente de $50 \%$ dos agricultores tinham contrato de arrendamento, enquanto a outra parte, possuidora de chácaras há mais de 30 anos, não tinha contrato e a Santa Casa nada fez. Este fato é explicado pela falta de administração das terras por parte da Provedoria da Santa Casa, que inicialmente não se interessou de fato por elas. Essa postura só muda nos anos 80 , quando as terras já haviam sido quase todas ocupadas pelos agricultores de ascendência japonesa, e a Santa Casa se vê diante da impossibilidade de demarcar corretamente as terras devido a vários fatores, entre eles (1) a dificuldade de identificar os marcos mencionados no contrato de doação; (2) a falta de legalização das terras junto aos órgãos competentes; (3) o fato de alguns agricultores terem contratos de arrendamento e outros não, somado à dificuldade de identificação dos verdadeiros arrendatários, por motivo da ampla difusão da prática de transferência informal dos lotes entre agricultores, sobretudo a partir da década de 90, quando as terras já estavam intensamente loteadas, sem que a Santa Casa fosse comunicada (4) e a ocupação de áreas de proteção dos mananciais da região.

Diante de tais irregularidades, a Santa Casa contratou uma empresa imobiliária, em 1995, a fim de regularizar a situação. Os funcionários da empresa contratada passaram, então, a visitar o bairro a fim de identificar moradores e estabelecer o contrato de arrendamento com os agricultores que não o possuíssem. Para isso, a empresa utilizou argumentos de coação, ameaçou cobrar as prestações em atraso e instaurou Ação de Reintegração de Posse contra dezenas de agricultores que se encontravam com o pagamento atrasado e também contra os que se negavam a efetuar o contrato ou a aceitar a imposição de novos contratos com valores aumentados.

O Dr. ZAMBOTTO 20 lembra que "a ação era sobre a terra, mas citava o nome do contratante e recaía sobre o atual dono". Tal atitude por parte da Santa

${ }^{20}$ O Dr. ZAMBOTTO nos concedeu uma entrevista, em seu escritório, no dia 15/03/2005. 
Casa serviu para criar um ambiente de desconfiança e de muita revolta entre os agricultores, que passaram a organizar um movimento ${ }^{21}$ contra o aumento no valor do arrendamento e as ações de despejo promovidas pela Santa Casa. Entretanto, se por um lado, as atitudes da Santa Casa serviram para forçar muitos agricultores a efetuar o contrato de arrendamento, por outro, serviram, também, para unificar os agricultores, que realizaram uma assembléia em que decidiram criar uma Associação e contratar um advogado para defender os interesses dos agricultores em luta pela terra. E após isso, uma nova assembléia decidiu pela suspensão total do pagamento do valor do arrendamento.

Diante da nova situação, a Provedoria da Santa Casa nomeou um advogado a fim de intermediar um processo de negociação entre ela e a Associação. Os agricultores demonstram interesse em adquirir as terras, no caso de o Governo Federal, por meio do INCRA, conceder o financiamento via Programa de Crédito Fundiário. Já houve várias negociações entre as duas entidades, inclusive com a participação de políticos locais e estaduais, além de representantes do INCRA e do ITESP, mas nada foi resolvido até o mês de julho de 2005, quando encerramos nosso estudo no bairro.

O Título 02 corresponde à parte das terras de menor extensão, medindo 192 hectares. Tem a menor quantidade de agricultores (164) e não está legalizada. Por isso mesmo, é a área mais problemática sob o ponto de vista jurídico.

Como a Santa Casa não possui o título desta parte de sua propriedade, fica impedida de celebrar contratos de arrendamento com os agricultores. Apesar disso, antes da criação da Associação dos Chacareiros e da contratação do Dr. ZAMBOTTO, ela celebrou dezenas de contratos de arrendamento com agricultores, com base no título de propriedade das terras do Título 01. A partir do momento em que a Associação contratou os serviços advocatícios do Dr.

\footnotetext{
${ }^{21}$ Este movimento, que contou a ajuda de políticos locais solidários à causa dos sem terra, serviu para dar visibilidade aos problemas que os agricultores vinham passando. A primeira ação do movimento foi a ida de vários caminhões carregados de verduras para frente da Prefeitura, onde se realizou a entrega gratuita das verduras à população. Uma segunda ação foi o fechamento da rodovia Estadual SP-39 (estrada das Varinhas) com a queima de pneus, impedindo dessa forma o trânsito local.
} 
ZAMBOTTO, as irregularidades foram descobertas e os agricultores foram orientados a pararem de pagar o arrendamento que, segundo o mesmo, era plenamente anulável.

\section{4 - As condições sociais e econômicas}

Os agricultores de Jundiapeba são em sua maioria membros de famílias que migraram de outras regiões do país. Há entre eles nordestinos sertanejos, gaúchos, norte-paranaenses e famílias de outras localidades do Estado de São Paulo. São em sua maioria famílias de poucas condições sócio-econômicas. Residem em pequenas casas (de quatro ou no máximo de cinco cômodos), podendo ser construção de alvenaria, o que é mais comum entre as que se localizam próximo à estrada "Municipal", ou de construção improvisada com piso de chão batido, como as encontradas próximo às margens do rio Jundiaí. São famílias numerosas, podendo ter de quatro a sete filhos. Possuem pouca mobília e aparelhos eletrodomésticos como fogão a gás, uma geladeira, uma televisão e um tanquinho semi-automático para lavar roupas.

Exceto as residências que se localizam em área de preservação dos mananciais, as demais estão ligadas à rede elétrica. Isso é de importância fundamental, pois todo sistema de abastecimento de água, doméstico e produtivo, depende de um motor elétrico (bomba) para ser alimentado. As famílias que vivem sem o fornecimento de energia elétrica passam enormes dificuldades: econômicas, por não conseguirem uma produção satisfatória; cultural, por não terem acesso aos meios de comunicação e entretenimento; e social, porque vivem, geralmente, isoladas e temem a violência facilitada pela falta de luz.

Além das famílias dos agricultores, há também no bairro rural muitas famílias de moradores. Os moradores, como são chamados, são famílias que não possuem chácaras e, em geral, têm condições econômicas inferiores às das famílias dos agricultores. A maioria vive do rendimento conseguido pelo assalariamento dos pais e dos filhos mais velhos que trabalham como empregados assalariados temporários ou permanentes nas chácaras dos 
agricultores, ou como meeiros em minúsculos lotes. Outros moradores, estes em menor quantidade, trabalham em atividades industriais da cidade ou região.

As famílias dos moradores estão organizadas em torno da Associação dos Moradores $^{22}$, que foi fundada com a finalidade de lutar, junto aos órgãos públicos, para conseguir o título de propriedade do terreno onde construíram suas improvisadas e precárias casas.

Há uma escola pública estadual na localidade, que só funciona durante o período diurno e que atende as crianças que freqüentam até o Ensino Básico $\left(1^{\mathrm{a}} \mathrm{a}\right.$ $4^{\mathrm{a}}$ série), mas não tem condições suficientes para atender todos os alunos. Como as vagas são insuficientes e a escola não possui o Ensino Médio, os estudantes têm que se deslocar para escolas de outros bairros do Distrito, para escolas do Distrito de Braz Cubas ou de outros Distritos mais distantes. Para os alunos do Ensino Fundamental que não conseguem vagas na escola da localidade, a Prefeitura disponibiliza um ônibus que leva e traz os estudantes para as outras escolas mais distantes. O estudo é muito importante para as famílias do bairro, apesar de a maior parte dos pais serem analfabetos. O fato de reivindicarem transporte para seus filhos estudarem em outros bairros, demonstra a importância que os pais dão à escola.

Algumas famílias de agricultores do grupo dos sulistas apresentam melhores condições de vida que as demais. São famílias que possuem veículos (de passeio) e caminhões, casa de alvenaria com iluminação elétrica, linha telefônica convencional etc. Este fato sinaliza para o estabelecimento do processo de diferenciação econômica no bairro. Entretanto, tal processo parece não interferir nas relações sociais quotidianas entre os agricultores sulistas com melhores condições e os demais, nem nas decisões que o grupo toma durante as reuniões da Associação.

Tal processo fica mais visível quando se comparam as condições sociais dos agricultores com as dos moradores. Estes possuem as piores condições da região, pois, moram em habitações improvisadas e com cômodos; com o mínimo

\footnotetext{
${ }^{22}$ Segundo o Presidente da Associação, o senhor MANOEL, ela congrega cerca de 400 famílias, cujo terreno de cada residência pode chegar ao total de 300 metros quadrados.
} 
de mobília. Possuem baixo grau de escolaridade e são famílias mais numerosas. Em sua maioria, vivem do salário (em torno de $R \$ 70,00 \mathrm{p} /$ semana) que os pais e filhos mais velhos recebem como temporários ou permanentes nas UPFs ou em algum outro emprego nas indústrias das cidades da região ou, ainda, do recebimento de algum auxílio governamental, sendo o mais comum o bolsaescola.

\section{5 - As relações sociais}

Com exceção do barracão, onde funciona a Sede da Associação, não há no bairro outro espaço físico destinado à realização de eventos que proporcionem o desenvolvimento de relações de sociabilidade, laços de amizades, de compadrio, comunitários ou mesmo a oportunidade de comemorarem alguma festividade cultural ou qualquer outro evento comunitário do bairro. O barracão é destinado às reuniões da Associação ou à realização de cursos e palestras, que geralmente são promovidos pela Prefeitura, pela Casa do Agricultor ou pelo Sindicato Rural.

Segundo o ex-presidente da Associação, o senhor WILSON, até poucos anos atrás, os agricultores chegaram a realizar algumas festas no galpão onde funciona a Sede da Associação, mas preferiu-se suspendê-las, em razão das constantes brigas que se formavam entre alguns agricultores. A explicação disso pode estar no fato de que a maioria dos agricultores é originária de várias regiões do país e está na área há relativamente pouco tempo (estão no bairro há 10 ou 15 anos). Cada um preserva muito do modo de ser e de agir da região de origem, e parecem estar ainda construindo a identidade cultural própria do bairro. A construção de uma relação social mais madura e permanente, só se realiza mediante o processo de construção e desconstrução dos elementos que formam a identidade cultural de cada grupo. Por isso é normal que, durante este processo de construção cultural, haja maiores desentendimentos e desconfiança de um para o outro, até que a convivência ao longo do tempo contribua para que as diferenças sejam aparadas. 
Apesar da existência da paróquia de Santo Ângelo não se realizam mais missas no bairro, em função da distância que ela fica com relação à centralidade do bairro. Exceto quando há novenas nas residências de um ou outro agricultor que é realizada pelo padre DANIELLI, da paróquia do centro da vila de Jundiapeba. Do contrário, os agricultores católicos, quando querem professar sua religião, têm que se deslocar até a paróquia localizada no centro da vila de Jundiapeba.

Já os agricultores evangélicos podem contar com a presença no bairro de quatro igrejas, uma das quais localizada no centro do bairro. Mas, a contar pelo tamanho muito pequeno delas e dos poucos horários de celebração de cultos, se percebe que a maioria dos agricultores não é evangélica.

Observa-se uma relação familiar e de vizinhança, relativamente forte, entre grupos de agricultores, o que é facilitado, sobretudo, pelo fato de que muitos casais são formados por indivíduos de famílias conterrâneas, o que contribui para aproximar os demais membros das famílias. Além disso, como a área dos lotes é extremamente pequena, a distância física entre as UPF é muita pequena, facilitando dessa forma, os laços de vizinhança entre agricultores situados num mesmo arruamento.

Também é interessante perceber que alguns pontos da centralidade passam a desempenhar a função de disseminadores de notícias, contribuindo para que as informações cheguem às partes mais afastadas do centro. Nos horários de entrada e saída das crianças na escola, as mães que levam os seus filhos à escola acabam se encontrando e estabelecendo laços de amizade. A freqüência ao mini-mercado por parte dos agricultores, ao final do dia de trabalho na lavoura, ou aos pontos de comércio, para "tomar um trago" ou para disputar partidas de sinuca, permite a troca de informações sobre os preços das mercadorias e o estabelecimento de relações sociais. A prática religiosa, realizada tanto nas igrejas quanto nas casas dos agricultores, também permite que as relações sociais de desenvolvam. 
Com a sociedade mais geral, as relações sociais se estabelecem mais comumente pela via econômica, isto é: com os comerciantes (feirantes, atravessadores e distribuidores) que vêm até o bairro para adquirir hortaliças; com os agentes que atuam no Mercado do Produtor Rural, na cidade de São Paulo; com feirantes e consumidores da feira, aos domingos, que se realiza em uma das praças da vila do Distrito de Jundiapeba e com outros agentes econômicos quando necessitam adquirir insumos ou produtos de uso pessoal. Entretanto, há outros níveis de relações sociais externas, tais como: filhos e filhas dos agricultores que se deslocam para outros bairros para cursarem o Ensino Médio; as constantes reuniões entre os membros da Diretoria com outras entidades a fim de resolver os problemas do bairro; os agricultores católicos, que se destinam à igreja do centro da vila de Jundiapeba; a visita de políticos, em época de eleição, a fim de angariar votos; a visita a outros bairros por ocasião de festas agrícolas, muito freqüentes no município etc.

\section{6 - A morfologia Agrária}

Em função da produção de hortaliças e do tamanho das propriedades, os agricultores deste tipo de unidade de produção se autodenominam chacareiros e sua unidade de produção, de chácara.

Neste trabalho, preferimos utilizar o termo UPF - Unidade de Produção Familiar - para denominar cada propriedade por compreendermos que o termo chácara no Brasil incorpora uma generalização muito ampla podendo abarcar pequenas propriedades agrícolas de produção familiar, como estas as quais estamos descrevendo, propriedades destinadas ao uso de moradia ocasional e até mesmo propriedades comerciais.

Assim, utilizamos o termo Unidade de Produção Familiar para designar um tipo de pequena propriedade rural, cuja área compreende a existência dois espaços: um destinado à produção econômica, com a qual se obtém os meios de subsistência e onde um grupo familiar trabalha autonomamente e explora as potencialidades naturais do solo e do clima, através do trabalho de seus membros com o auxílio de tecnologias (máquinas, equipamentos e insumos agrícolas); 
outro, integrado, interdependente e inseparável do primeiro, que compreende o espaço sobre o qual está construída a moradia da família. As atividades que se desenvolvem nos dois espaços são complementares e promovem a interação e o convívio familiar.

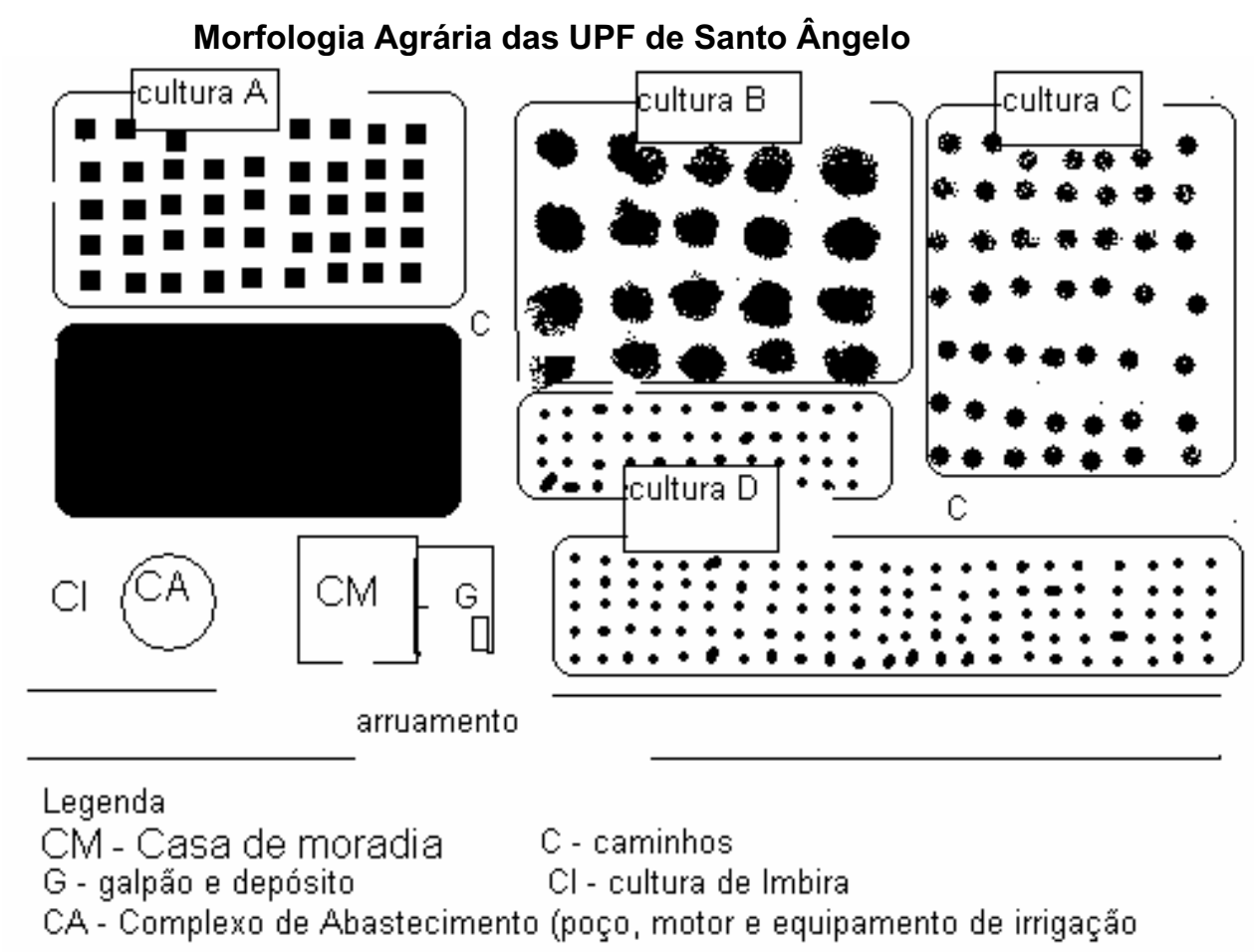

Organizado por Antônio Carlos da Paz Santana

O espaço destinado à produção compreende: a área de lavoura; o galpão que se destina à lavagem e encaixamento das hortaliças e ao depósito de insumos, adubos e guarda do mini-trator e demais ferramentas; o complexo de abastecimento de água, isto é, o poço, o motor e o sistema de irrigação e os caminhos necessários à circulação e distribuição das mercadorias aos mercados consumidores. O espaço da casa de moradia, por sua vez, compreende a residência e os demais anexos utilizados para o desenvolvimento de atividades domésticas e de lazer da família.

Desse modo, a UPF constitui uma única unidade, indivisível, que compreende atividades de produção e de moradia. As atividades que se desenvolvem na UPF são interdependentes; complementares; inseparáveis e de 
vital importância para a manutenção e reprodução do grupo familiar. Apesar de à primeira vista, parecerem distintas, elas cotidianamente são desenvolvidas em todos os lugares da unidade, promovendo a interdependência e a interação entre os membros da família. A família, tanto trata dos problemas relacionados à produção, na moradia, quanto aos de caráter mais doméstico, na lavoura, pois, o convívio social familiar ocorre naturalmente em todos ambientes da unidade.

Desse modo, a UPF não é apenas o lugar onde a família produz ou mora, mas se constitui num espaço vital para a sobrevivência econômica, social e cultural da família. Ela constitui o lugar da produção dos meios de sobrevivência da família; do abrigo e segurança da família; da reprodução da família; da autonomia da família; da manifestação e da reprodução dos elementos culturais; onde os membros da família se sentem livres para receber os parentes, amigos e vizinhos.

A morfologia das UPF foi estruturada a partir do sistema agrícola que por sua vez é praticado de acordo com às exigências do mercado consumidor. Ela compreende um único espaço que integra as atividades relacionadas à produção econômica, com a qual se obtém os meios de subsistência, e as de caráter doméstico. Tais atividades, que são interdependentes e complementares, se realizam em todos os ambientes da unidade de produção e promovem a interação entre os membros da família no convívio.

A área destinada à produção, propriamente dita, compreende a existência de quatro elementos essenciais: (1) a área de lavoura; (2) o galpão; (3) 음 complexo de abastecimento de água, isto é, o poço, o motor e o sistema de irrigação e (4) os caminhos necessários à circulação e distribuição das mercadorias aos mercados consumidores.

1 - a área de lavoura - corresponde à parte da área da unidade de produção que se destina ao plantio das culturas.

2 - o galpão - é, geralmente, uma extensão da casa, que é construída externamente. Ele se destina à lavagem e a acomodação em caixas das hortaliças e ao depósito de insumos, adubos e à guarda do mini-trator, de acessórios e 
demais ferramentas agrícolas. Está localizado à beira do arruamento, para facilitar o escoamento da produção, e perto do sistema de abastecimento de água.

3 - o complexo de abastecimento de água - compreende a existência de um poço; de um motor elétrico ou a diesel e os equipamentos que formam o sistema de irrigação e de abastecimento doméstico da casa de moradia. Tais equipamentos são vitais para a produção de hortaliças e verduras, sem eles é quase impossível produzi-las, uma vez que o consumo de água é muito grande por parte das culturas, principalmente durante as estações de seca, quando diminui o índice pluviométrico e cai a umidade relativa do ar. Por outro lado, como já vimos, não há fornecimento de água pelas empresas, tanto municipal (SEMAE) como estadual (SABESP), que atuam na região, apesar da rede de abastecimento passar ao lado do bairro.

4 - os caminhos - constituem espaços estreitos e permanentes entre as quadras por onde as pessoas circulam efetuando atividade entre a área de lavoura e o galpão ou a casa de moradia. Os caminhos também dão acesso aos arruamentos, por onde circulam os automóveis e caminhões de transporte de mercadorias, e que se ligam à estrada "Municipal". Essa, por sua vez, se liga à rodovia SP-39 ligando-se, por fim, às demais rodovias que dão acesso às cidades do Estado e do país.

\section{7 - A estrutura agrária}

A maioria dos lotes não chegam a atingir 2 hectares por UPF, variando em torno de 0,8 a 1,2 hectare por unidade. Somente um pequeno número dos lotes tem área superior a 20,0 hectares, mas nenhum deles ultrapassa 40 hectares. Na verdade, só há um único agricultor que tem a posse de dois lotes que somados chegam ao total de 40,0 hectares.

Segundo nossas pesquisas, as quais foram submetidas às correções da secretária da Associação dos Chacareiros, D. Cida, o número total de UPF é de 284 unidades e somando-se todas as áreas que cada uma ocupa chega-se ao total de 684 hectares. O total de 284 unidades se refere ao número de UPF e não 
ao número de lotes, pois o grupo familiar poderá tem a posse de um ou mais lotes de terras.

Há dificuldades para se estabelecer o quadro da estrutura fundiária, pois a medida de área utilizada pelos agricultores é a quadra ${ }^{23}$ e não nos foi possível estabelecer um tamanho padrão para ela. Foram encontradas diferentes medidas, tanto entre as quadras de uma só UPF, quanto entre as 284 UPF. O tamanho pode variar de acordo com a quantidade de canteiros que se pode obter, em cada quadra, após a realização dos trabalhos de "tombamento", "riscagem" do solo e formação dos canteiros ou de acordo com o produto a ser plantado, ou, ainda, pode variar de acordo com o tamanho da área de lavoura. Segundo um agricultor, o senhor CíCERO ${ }^{24}$, uma quadra pode conter de 60 a 120 canteiros, se for considerado um espaçamento mínimo de 20 centímetros entre as covas.

\section{8 - O sistema agrícola}

O sistema agrícola adotado é o de rotação de culturas associada ao uso intenso do solo. Pode ser caracterizado como sendo um sistema intensivo de mão-de-obra que é praticada em pequenas propriedades, sem grandes investimento de capital, que utiliza uma técnica de uso do solo que requer muito trabalho.

VALVERDE (1964) compreende que para se estudar o sistema agrário é necessário, além da compreensão da ação do homem sobre a vegetação, relevo e do clima deve-se, também, buscar a compreensão tanto da morfologia quanto da estrutura agrária. Enquanto a morfologia se refere à disposição das parcelas cultivadas, às cercas, localização das casas, etc., isto é, como estão distribuídas as construções sobre o solo, a estrutura agrária se refere às relações entre 0 homem e a utilização do solo. Ainda assim, não basta descrevê-las: é necessário interpretá-las, compreender como funciona cada um dos elementos se refletem na paisagem.

\footnotetext{
23 É muito comum na localidade se ouvir dizer que um determinado chacareiro "tem uma quadra" ou que tem " $\mathrm{x}$ " quadras, para se referir à chácara da pessoa.

${ }^{24} \mathrm{O}$ senhor CÍCERO foi um dos agricultores entrevistados por nós. A entrevista, que ocorreu em 03/07/2004, foi realizada na UPF na qual é meeiro do senhor WILSON.
} 
A rotação de culturas é o sistema agrícola praticado por todos os agricultores de hortaliças de Santo Ângelo, pois a subordinação ao mercado é um dos fatores limitante à adoção de outros sistemas, pois requer dos agricultores um processo de exploração do solo que se realiza mediante ao uso intensivo de todos os espaços naturais disponíveis, ao combate intensivo de pragas e doenças e a um eficiente sistema de irrigação de água que demanda, também, a intensificação da mão-de-obra familiar, já que os agricultores em sua maioria não possuem condições para adquirir mão-de-obra assalariada.

As hortaliças permitem uma grande rotatividade em seu cultivo em função do seu curto ciclo biológico. Para combater as pragas e doenças decorrentes do déficit dos nutrientes do solo que são consumidos quase que pelos mesmos vegetais, faz-se uso contínuo e intensivo agrotóxicos.

Este tipo de sistema agrícola exige dos agricultores a realização das seguintes atividades:

(a) formação dos canteiros - o trabalho inicia-se com o uso de um minitrator, que aciona um equipamento chamado de rotativa, cuja função é o de revolver (tombar) a camada superficial do solo; a seguir com o uso de um de seus acessórios, o riscador, realiza-se o trabalho de riscagem do solo, quer dizer, marcar levemente o solo delineando a direção por onde serão formados os canteiros; após isso, procede-se à troca do acessório riscador pelo canteiradeira, que, por sua vez, é utilizada na formação dos canteiros.

(b) plantio de sementes - é efetuado após o trabalho de formação dos canteiros e consistem na formação das covas, por um dos membros da família, é realizado obedecendo-se a uma distância média de 20 centímetros entre elas. A seguir, passa-se a efetuar a irrigação, por aspersão ou mangueira, diariamente nos períodos da manhã, antes do nascer do sol, e da tarde, após o pôr do sol.

(c) aplicação de agrotóxico - durante o desenvolvimento das plantas, ocorre também o aparecimento de ervas daninhas, sendo necessário efetuar, ocasionalmente, a limpeza dos canteiros, que se realiza com um instrumento apropriado, e de bactérias, que devem ser combatidas com o uso de agrotóxicos, para evitar o amarelamento das folhas e o prejuízo pela perda da produção. 
O uso de agrotóxicos ${ }^{25}$, que basicamente consiste na pulverização das plantas, é mais intenso durante as estações de temperaturas quentes e de alta umidade, necessitando de aplicações quinzenais, mensais ou semestrais dependendo do tipo da cultura e do amarelamento das plantas, pois, as bactérias se proliferam mais nestas condições; e menos intenso durantes as estações de temperaturas e umidade baixas, quando a proliferação de bactérias diminui sensivelmente.

A maioria dos agricultores de Santo Ângelo realiza a aplicação de agrotóxicos sem o uso de equipamentos de proteção à saúde, logo é fácil compreender porque são comuns os casos de intoxicação.

(d) irrigação - a irrigação é realizada mediante o sistema de abastecimento de água. Toda UPF tem seu sistema, que consiste na retirada de água de poço, pelo método mecânico-elétrico, e irrigada até às áreas de cultivo, por um conjunto de canos, até o cilindro dispersor geralmente colocado no meio dos canteiros. Este sistema por aspersão é praticamente o único utilizado pelos agricultores, embora o sistema de gotejamento seja o mais recomendável em função da economia de água. Mas, parece que essa preocupação não atingiu ainda os agricultores, que preferem utilizar o sistema menos eficiente. Talvez isso se explique pelo nível do lençol freático que é muito superficial na maior parte do bairro.

Depois de um período que pode variar de dois a seis meses dependendo do tipo da hortaliça, efetua-se a colheita, a amarração, a lavagem, o encaixamento e o escoamento para os mercados consumidores.

(e) as técnicas pós-colheita - após a colheita, localmente conhecida como tirar verduras ou mercadorias, que consiste na retirada das plantas mediante aplicação de uma força suficiente para arrancar do solo, providencia-se a amarração e a lavagem das plantas, que são realizadas no galpão. A tarefa de formação dos maços (pelo sistema de amarração) ou de separação das mercadorias, varia conforme o padrão de venda e a lavagem (pelo sistema de

25 O uso obrigatório de roupa e equipamentos protetores para a aplicação de agrotóxicos não é muito respeitado pelos agricultores desse bairro. 
mergulho num tanque de água) é realizada para se eliminar possíveis insetos ou larvas e se retirar o excesso de terra existente. Após estas tarefas, procede-se à acomodação e arrumação das mercadorias nas caixas (de polietileno), que geralmente são fornecidas pelos consumidores, por quantidade e variedade segundo os pedidos dos clientes. Os agricultores que não têm clientes fixos, ainda utilizam caixas de madeira para acomodar as mercadorias.

A melhor estação para o cultivo de hortaliças é contraditória à estação de maior consumo. As estações mais quentes do ano não são as mais indicadas para o plantio, pois as altas temperaturas e elevada umidade, provocada pelo alto índice pluviométrico, beneficiam a proliferação de bactérias e doenças. É no inverno, com as baixas temperaturas e a baixa umidade, que elas se desenvolvem melhor e apresentam um aspecto mais saudável. Os pés de alface, por exemplo, ficam maiores e as folhas, apresentam uma coloração verde mais definida. Por outro lado, é no verão que o consumo aumenta em decorrência de um maior consumo de alimentos leves, como as saladas. Geralmente, é no início da primavera que a demanda dobra e muitos agricultores não conseguem atender a todos os pedidos. Estes fatores, somados ao elevado índice de perecibilidade das hortaliças, acabam prejudicando a produção.

Por outro lado, a ocorrência de solos do tipo húmico, típico das áreas de várzea e formados, segundo GUERRA (1975), em região de clima frio, onde os vegetais não foram carbonizados antes de serem apodrecidos, em locais de água limpa e de solos pouco profundos, favorecem a produção agrícola durante as estações secas, ao manterem as raízes sempre úmidas. Mas, por outro, durante as estações chuvosas, aproximadamente um quinto do total das unidades ficam impedidas de produzirem, pois os solos se tornam impraticáveis em função das cheias que se formam às margens do rio Jundiaí, permanecendo dessa forma por dois a três meses.

É, principalmente neste período, que se verifica a maior ocorrência do fato de alguns agricultores trocarem de atividade, isto é, deixam, temporariamente, a atividade agrícola e passam a exercer a atividade de comerciante. Por isso, é que preferimos denominá-los de agricultores-comerciantes. 


\section{9 - Principais Produtos Cultivados}

As análises sobre a produção foram feitas com base na aplicação do questionário "Pesquisa de Atualização Demográfica e Sócio-Econômica" que realizamos junto aos agricultores, entre os meses de julho e setembro de 2004.

Os agricultores do bairro rural do Distrito de Jundiapeba produzem, essencialmente, hortaliças, sendo as mais cultivadas a cebolinha, a salsa, o coentro, a alface e o brócolis, que, apesar de serem mais adaptadas à estação de inverno, quando as temperaturas baixam e as chuvas escasseiam, aumentando consideravelmente a produção, são cultivadas o ano todo. Eventualmente, um ou outro agricultor, dependendo das condições de preços no mercado, pode produzir além de hortaliças outros produtos, como hortelã, orégano, arruda, alecrim etc.

A seguir, relacionamos na tabela abaixo, as principais culturas produzidas durante os meses de julho, agosto e setembro.

Principais Produtos Cultivados durante os meses de julho, agosto e setembro de 2004.

\begin{tabular}{|c|c|c|c|}
\hline $\begin{array}{c}\text { Principais Produtos } \\
\text { Cultivados }\end{array}$ & $\begin{array}{c}\text { Modalidade } \\
\text { Comercializada }\end{array}$ & Principais Produtos & $\begin{array}{c}\text { Modalidade } \\
\text { Comercializada }\end{array}$ \\
\hline salsa & maço & alface & caixa \\
\hline cebolinha & dúzia & nabo & dúzia \\
\hline brócolis & dúzia & escarola & caixa \\
\hline rúcula & dúzia & agrião & maço \\
\hline coentro & maço & couve-flor & dúzia \\
\hline repolho & caixa & almeirão & dúzia \\
\hline beterraba & dúzia & catalonha & dúzia \\
\hline rabanete & dúzia & manjericão & dúzia \\
\hline cenoura & caixa & espinafre & dúzia \\
\hline repolho & caixa & almeirão & dúzia \\
\hline
\end{tabular}

Fonte: Pesquisa de Campo

\subsection{0 - Os elementos da Produção}

O motor da produção das UPF é a força de trabalho familiar. Enquanto os homens realizam as tarefas mais pesadas (aquelas que necessitam da utilização do micro-trator como tombar a terra, riscar e nivelar canteiros), limpar canteiros, 
tratar da compra de insumos e da venda da produção, cabe às mulheres, além das atividades domésticas e da criação dos filhos menores, a participação no trabalho da colheita, na contagem (por unidade ou dúzia), na montagem (de pacotes ou maço ou caixa) e na lavagem das mercadorias que serão destinadas ao mercado consumidor. Entretanto, é possível encontrar mulheres realizando tarefas que habitualmente deveriam ser realizadas pelos homens da família.

Há a utilização de trabalhadores assalariados temporários, cujo salário varia em torno de $\mathrm{R} \$ 70,00$ por semana. Eles são contratados geralmente para efetuar os trabalhos mais difíceis, como o de "tombar" a terra ou "tirar" mercadorias das quadras, nos períodos de grande demanda. Sabe-se que o período do verão é o de maior consumo de verduras e de hortaliças, o que demanda uma maior intensidade de trabalho. Há, também, mas em número bem mais reduzido, trabalhadores permanentes assalariados que recebem um salário que varia em torno de $\mathrm{R} \$ 280,00$ a $\mathrm{R} \$ 360,00$ por mês.

A mão-de-obra acessória que é proveniente das famílias de moradores, é muito necessária para a produção de hortaliças, porque os agricultores podem fazer uso dela nos período de tombamento da terra; de maior demanda ou quando há uma superprodução, porque este tipo de cultura possui um ciclo biológico muito curto e, se não for colhida/tirada a tempo, pode implicar prejuízos para o grupo familiar.

Há casos, em que é preferível contratar mão-de-obra acessória, mesmo que isso implique um maior custo de produção, do que deixar que a produção se perca por não ter sido tirada/colhida a tempo. Esta é uma maneira que os agricultores utilizam para "ajudar" os desempregados ou mais necessitados do bairro.

As terras que os agricultores cultivam não são próprias. Mas, isto não quer dizer que eles não pagaram para fazer uso do solo. Para poder ter o direito sobre o uso da terra, eles tiveram que comprar a posse (luva) de um outro agricultor. Logo após a criação da Associação e a contratação dos serviços advocatícios do Dr. ZAMBOTTO, e por indicação dele mesmo, a maior parte dos agricultores pararam de pagar o arrendamento. Quase a totalidade dos 
agricultores, apesar de ser consciente da situação da posse irregular, não paga a renda da terra. Apenas um ou outro ainda continua pagando o arrendamento à Santa Casa.

Segundo o Dr. ZAMBOTTO, no contrato de arrendamento celebrado entre a Santa Casa e os agricultores, havia uma cláusula inconstitucional que obrigava os agricultores a doar para a Santa Casa todas benfeitorias construídas por eles quando o contrato fosse encerrado ou se os agricultores fossem despejados por falta de pagamento. A partir disso, os agricultores pararam de pagar 0 arrendamento. Segundo informação dos agricultores, os contratos tinham seus valores bastante diferenciados, parecendo não haver critérios claros para a determinação dos valores, seja em relação ao tamanho ou à localização da chácara. Os valores variavam muito: alguns eram no valor de $\mathrm{R} \$ 30,00$, outros no valor de $R \$ 40,00$ e ainda poderiam chegar a $R \$ 300,00$ ou mesmo $R \$ 450,00$ por mês.

Todos os agricultores fazem uso do micro-trator (a Tobatta é uma marca de uma fábrica de tratores japonesa, que foi quem difundiu este tipo de máquina no cultivo de hortaliças no Brasil). Entretanto, nem todos são proprietários, alguns alugam ao valor de $\mathrm{R} \$ 30,00$ ao dia, mais o valor das despesas com consumo do combustível. Este mini-trator e seus acessórios, praticamente, são suficientes para se realizar as principais tarefas necessárias à produção de hortaliças. Com ele, um trabalhador experiente consegue tombar o solo, riscar e nivelar os canteiros de uma área de um hectare em apenas um dia de trabalho.

A jornada de trabalho dos agricultores começa logo cedo, por volta das 5 horas, antes de o sol nascer e se estende por todo o período de sol. A cultura de hortaliças exige um intenso trabalho e cuidados especiais do agricultor. Logo cedo, pela manhã, devem ser molhadas para que o orvalho da madrugada não queime as folhas quando o sol nascer. Ao entardecer, carecem de mais água e o processo da colheita exige mãos habilidosas para selecionar, tirar/cortar, separar, amarrar, lavar e armazenar em caixas de madeiras ou plásticas. 
Após a irrigação ser realizada, pela manhã bem cedo, os agricultores passam para o processo de colheita ou, no linguajar deles, de "tirar mercadorias" ou "tirar verduras", isto é, colher.

O período da tarde é dedicado à limpeza dos canteiros, irrigação, novas colheitas e entrega de mercadorias no mercado e/ou aos atravessadores e feirantes que vão "puxar mercadorias" diretamente nas chácaras.

O intenso uso do solo é uma característica comum entre os agricultores de pequenas UPF que utilizam o sistema de rotação de culturas, mas, quando se trata da produção de hortaliças o uso passa a ser ainda mais intenso. Todos os espaços interiores às UPF são potencialmente utilizados para se realizar alguma atividade.

Com exceção de um único criador de vacas (que comercializa o leite no próprio bairro), todos os agricultores do bairro utilizam o solo exclusivamente para o cultivo de hortaliças, sendo muito pequeno o número de agricultores que cultiva produtos para o consumo próprio. Quando isso ocorre, os agricultores preferem plantar o milho, o feijão e a mandioca. As criações de patos e galinhas são as preferidas pelos agricultores, se bem que tais criações, apresentam uma quantidade insignificante de cabeças por rebanhos.

Há uma modalidade de ajuda mútua entre os agricultores. Segundo um agricultor, o senhor DORACI, esta prática é bastante comum entre eles. Quando alguém necessita efetuar um trabalho extra, ocasionado por um pedido maior de mercadorias, pede ajuda a um vizinho e, após o término do trabalho, "paga-se" o dia de serviço. A solidariedade se estabelece a partir daí, pois o primeiro agricultor ficará em dívida com o colega, mesmo tendo pago o dia de trabalho do outro. E, quando o seu vizinho precisar de ajuda, ele deverá trabalhar da mesma forma. Ou seja, quem pediu ajuda, mesmo pagando por ela, ficará na obrigação de devolver o dia de trabalho "pago" quando seu colega necessitar.

\subsection{1 - Os mercados consumidores}

Não há uma forma organizada pelos agricultores, apesar da existência da Associação, para o escoamento coletivo da produção para os mercados 
consumidores. Basicamente, o escoamento se faz a partir de três pontos ou modalidades de venda, relacionados a seguir conforme a importância decrescente dos volumes de produção escoados: (1) no mercado CEAAP - Central de Abastecimento de Agroprodutores; (2) diretamente nas UPF; (3) nas distribuidoras que atuam na região.

Os maiores volumes são destinados para o CEAAP, que se localiza na zona cerealista da cidade de São Paulo, onde alguns agricultores possuem boxes ou mantêm entrega regular com alguns comerciantes. O segundo ponto de venda ocorre diretamente nas UPF, onde muitos atravessadores, aproveitando-se dos agricultores que não têm veículos e por isso ficam impossibilitados para transportar as mercadorias até o CEAAP ou a outros mercados, circulam com seus caminhões por entre as UPF, adquirindo mercadorias a baixos preços. Essas mercadorias se destinam a empresas distribuidoras que se localizam no centro da vila de Jundiapeba, partindo daí para abastecer supermercados, feirantes e outros mercados localizados na região metropolitana da Grande São Paulo. Agindo do mesmo modo, há também uma minoria de feirantes que comercializam as mercadorias em feiras livres nos bairros dos municípios ou nos da capital ou de outras cidades da região.

O terceiro ponto ou modalidade de venda, que é o de menor volume comercializado, ocorre nos locais onde funcionam as empresas distribuidoras, as CDRs - Centrais de Distribuições Rurais ${ }^{26}$-, cuja comercialização, que se realiza mediante contrato e o cumprimento de várias exigências (qualidade, higiene, variedade, fiscalização etc.). Poucos agricultores possuem condições para atender as exigências estabelecidas no contrato. Somente, três famílias de agricultores do bairro participam dessa modalidade de comercialização. Tais, distribuidoras, após processarem minimamente as hortaliças, as distribuem para grandes redes de supermercados do Vale do Paraíba e fundo do Vale, Baixada Santista, região metropolitana do Grande-Rio de Janeiro e de Belo Horizonte e Triângulo Mineiro.

\footnotetext{
${ }^{26}$ Trata-se da venda a grandes distribuidoras do município de Biritiba Mirim: Verde \& Cia, Takagaki, Kimoto, Kitazawa e Terra Nova.
} 
Há, ainda, uma espécie de "venda" que ocorre no interior do próprio bairro: trata-se de um tipo de "venda" bastante esporádico, que ocorre entre os agricultores-comerciantes e os agricultores. Estes, apesar de serem agricultores, compram, eventualmente, mercadorias de seus vizinhos para complementar um pedido de algum cliente seu que foi maior que sua produção do dia da entrega. Às vezes, pode acontecer de o montante colhido no dia da entrega, ser inferior ao solicitado pelo cliente, neste caso o agricultor, para não perder o cliente, passa a adquirir o restante das mercadorias com os seus colegas, ficando este devendo o favor para o colega que "cedeu" as mercadorias faltantes. Seria necessário examinar mais profundamente para se averiguar se isso poderia ser uma espécie de ajuda mútua, pois a forma se assemelha muito àquela que já retratamos no capítulo sobre os elementos da produção.

Esta é uma necessidade, de certo modo, comum entre os agricultores que possuem as maiores unidades e que nem sempre podem contratar mão-de-obra acessória. Ela não poderá ser confundida com a atividade comercial dos atravessadores, que praticam atividades com a finalidade exclusiva de obter lucros. Já os agricultores-comerciantes, têm por finalidade complementar um pedido de um cliente, numa determinada ocasião em que sua produção não foi suficiente para atendê-lo. Foi em função disso, sobretudo, que nós não a consideramos como uma modalidade regular, como as demais mencionadas, de "comércio" entre os agricultores.

A venda direta na própria chácara é a modalidade, de certo modo, preferida pelos agricultores que não possuem veículos para transportar sua produção até os mercados formalmente instituídos, apesar da situação de sujeição em que se encontram. O que, também, não seria diferente caso comercializassem a produção com outros agentes ou mercados.

\subsection{2 - A identidade social}

A partir dos elementos constitutivos da produção camponesa que foram descritos por OLIVEIRA (1994) e do modo como os agricultores de Santo Ângelo se relacionam entre si e com os mercados e das condições sócio-econômicas 
apresentadas, podemos identificar a existência de dois grupos de agricultores, que se diferenciam conceitualmente entre si.

O primeiro grupo, representado pelo senhor MENININHO, tem a organização da produção baseada no trabalho familiar; constitui a maioria absoluta da totalidade dos agricultores. Esses indivíduos se relacionam com o mercado com a finalidade de adquirir dinheiro para a subsistência do grupo familiar, embora sua produção se destine exclusivamente ao mercado. O seu modo de vida se aproxima do conceito de camponês descrito por MARQUES:

O campesinato possui uma organização da produção baseada no trabalho familiar e no uso como valor. O reconhecimento de sua especificidade não implica a negação da multiplicidade de formas de subordinação às quais pode apresentar-se submetido, nem da multiplicidade de estratégias por ele adotadas diante de diferentes situações e que podem conduzir ora ao "descampesinamento", ora à sua reprodução enquanto camponês. (2002 pág. 1).

Já o segundo grupo, representado pelo senhor LOURENÇO, é formado por agricultores que baseiam a organização de sua produção no trabalho assalariado ou de meeiros; arrenda terras e organiza o sistema agrícola de acordo com a demanda do mercado. São os que possuem as maiores UPF, têm a produção mecanizada e visam sempre ao lucro na perspectiva da expansão das atividades e não à subsistência da família. Assim, compreendemos que os agricultores deste grupo podem ser classificados como pequenos capitalistas. Ou, ainda, como afirmou OLIVEIRA (1990) ao se reportar às relações de produção capitalista:

$\mathrm{Na}$ agricultura, para que essa relação ocorra, é necessário que o capitalista compre ou arrende a terra, que é o principal meio de produção no campo. É preciso também que compre os demais meios de produção, as máquinas, as ferramentas, os insumos etc. É por isso que o capitalista contrata no mercado o trabalhador livre de todos os meios de produção, inclusive da terra, e em troca Ihe paga um salário em dinheiro, com o qual ele compra tudo o 
que necessita para continuar a ser trabalhador e vender a sua força de trabalho ao capitalista. (1990 p. 65). 


\section{CAPÍTULO III - A ORGANIZAÇÃO DO MERCADO DE HORTALIÇAS DA CIDADE DE SÃO PAULO}

Este terceiro capítulo analisa a formação e a participação da produção do cinturão verde mogiano e das cooperativas que atuaram nos mercados de hortaliças da cidade de São Paulo. A partir disso, discute os fatores do processo de constituição dos principais canais de distribuição e abastecimentos existentes nestes mercados e como seus mecanismos de monopolização subordinam a produção dos agricultores.

Os agentes econômicos (atacadistas), aqueles que atuam diretamente no front da comercialização, possuem uma situação estratégica e privilegiada sob o aspecto da informação com relação aos volumes comercializados e às novas tendências do mercado consumidor, pois tais mercados constituem o ponto de chegada dos maiores volumes de alimentos frescos produzidos no país. De posse desta situação, estes agentes são os que estabelecem a subordinação da produção à circulação.

Os agricultores que, constituem o ponto inicial da cadeia produtiva, dependem destes mercados para escoarem sua produção. Mas, nem sempre têm acesso à todas informações sobre o mercado ou por estarem envolvidos diretamente na produção ou porque elas ainda são muito técnicas ao nível de sua compreensão.

A fim de compreendermos como tais relações se desenvolvem (mercado versus agricultor) e a conseqüente subordinação, imposta ao agricultor, como resultado dela realizamos um estudo sobre a atuação dos agentes econômicos nos principais canais de comercialização e de distribuição que constitui estes mercados.

Assim, organizamos este capítulo do seguinte modo: no tópico 1 - A contribuição da agricultura de Mogi das Cruzes, realizamos um resgate da formação da paisagem agrária deste município, baseado em relatos históricos e orais, a fim de compreender a importância de sua produção nos mercados paulistanos; no tópico $\underline{2}$ - A contribuição das cooperativas, será discutida a participação e o fechamento das maiores cooperativas que atuaram no setor 
hortifrutigranjeiro nos mercados paulistanos, durante as últimas décadas do século XX e no tópico $\underline{3-A}$ organização atual do mercado paulistano de hortaliças, será discutido os fatores responsáveis pela criação de políticas públicas relacionadas ao abastecimento alimentar nos grandes centros urbanos; a participação das centrais de abastecimento paulistanas e finalizamos esta parte com um esboço explicativo sobre a participação de cada agente que integra o mercado de hortaliças da cidade de São Paulo.

\section{1 - A contribuição da agricultura de Mogi das Cruzes}

A vila de Santa Ana deu origem à cidade de Mogi das Cruzes. Fundada, em 01/09/1611, por colonos portugueses que após terem saído da vila de São Paulo, em 1608, e liderados por GASPAR VAZ, receberam sesmarias e passaram a constituir o novo povoamento nas terras aonde habitaram os índios da tribo Boigy.

O que pode ser divisado, nos princípios da história do povoado e depois vila de Santa Ana, é um agrupamento social que se formou em São Paulo, e saiu de lá premeditadamente; ou mesmo formou-se depois. Eles se fortaleceram com a obtenção das terras, uma vez que tinham os mesmos objetivos: conquistar uma situação que não Ihes havia sido permitida na vila madre. Certamente fugiam da situação de má distribuição de terras, por as adquirirem nos piores ou mais longínquos locais; ou mesmo por não tê-las ganho. (MARQUES DIAS, 2001, págs. 61 e 62).

MARQUES DIAS (2001), ainda, ao se referir sobre as razões pelas quais se criasse um povoado naquela área, afirma que elas faziam parte de um projeto, pensado e iniciado pelo governador D. Francisco de Sousa, que, entre outras se incluía: o estabelecimento de uma maior interligação econômica entre as colônias espanholas e portuguesas; a criação de aldeamentos para fornecimento institucionalizado de mão-de-obra e a produção da triticultura extensiva, a fim de sustentarem uma possível mineração na região. "A articulação entre Santa Ana e demais vilas da capitania iniciou-se com o bandeirantismo" que teria desenvolvido um campo de cultivo de trigo e o "comércio de produtos locais com o litoral". 
Desse modo, compreende-se que o surgimento do povoamento que deu origem a Mogi das Cruzes, deve ser explicado com base nos interesses econômicos coloniais, objetivados pelo governador $\mathrm{D}$. Francisco, que faziam parte de um amplo projeto de articulação geográfica regional.

A seguir, demonstraremos como este povoamento articulou sua produção agrícola com os mercados regionais que incluíam, principalmente, os da cidade de São Paulo. Demonstraremos ainda como a área agrícola do município de Mogi das Cruzes, ao longo de sua história, foi transformada numa área especializada na produção de hortaliças após ter renunciado ao cultivo de produtos tradicionais, como o trigo, o algodão, a cana de açúcar, o café e o fumo, que foram cultivados desde os primeiros momentos da ocupação até o período pós-colonial.

Com relação a alguma bibliografia que pudesse nos dar uma idéia a respeito da produção agropecuária, da vila de Santa Ana, do período que vai da fundação da vila até o século XIX, só encontramos algumas citações históricas na obra História de Mogi das Cruzes: Do Começo até 1954, publicada em 1961, de ISAAC GRÍNBERG ${ }^{27}$. A primeira que, infelizmente, GRÍNBERG cujo nome da obra não citou, refere-se a uma certa visita que o Monsenhor Paulo Camargo realizou a vila de Santa Ana, em 1717, e a outra se refere à obra de AYRES DE CASAL, Corografia Brazilica, publicado em 1817.

Assim, segundo GRÍNBERG, o Monsenhor Paulo Camargo, em 1717, que em visita a vila de Santa Ana, constatou que ela "teria duzentas casas, mas era uma vila solitária, pois os moradores viviam nas roças e só vinham quinta-feira santa ou noutras festividades". (Cf. GRÍNBERG, 1961, págs. 32).

Ainda, segundo GRÍNBERG, sobre as condições em que viviam os habitantes de Santa Ana, os oficiais da Câmara dirigiram uma representação ao Rei de Portugal, D. José I, em 1751, expondo a terrível situação de pobreza de seus habitantes, que não possuíam meios e viviam sob grande pobreza. E era a população, quinze anos mais tarde, de 2.138 pessoas residindo em 483 casas. (Cf. GRÍNBERG, 1961, págs. 32, 32 e 40).

\footnotetext{
${ }^{27}$ ISAAC GRÍNBERG é o autor de maior número de publicação de obras sobre a História de Mogi das Cruzes.
} 
Na segunda referência, GRÍNBERG, citando a obra, Coreografia Brazílica, publicada em 1817, por AYRES DE CASAL, apresenta a seguinte descrição, feita por este autor, sobre a paisagem mogiana: "Tem professor Régio de Latim. As cazas sam de taipa, e seus moradores cultivam víveres, criando gado, e fazem grandes plantações de algodão, cuja produção faz a sua riqueza. Também daqui sahe alguma ágoa-ardente". (Cf. GRÍNBERG, 1961, pág. 46).

A partir, portanto, de tais citações, pode-se pensar então que até os últimos anos do século XVIII e início do XIX, a população mogiana apresentava grande pobreza, uma vez que os relatos dão conta de que as casas eram de taipa e sem muitos meios de sobrevivência. A produção agropecuária, basicamente, composta pelo cultivo de algodão e pela criação de poucos animais, era insuficiente para atender satisfatoriamente às necessidades da população. ${ }^{28}$

Na obra intitulada Segunda Viagem do Rio de Janeiro a Minas Gerais e São Paulo, de SAINT HILAIRE, citada por GRÍNBERG, consta um pequeno trecho sobre as condições da agricultura de Mogi das Cruzes que foram observadas por HILAIRE, em 1822:

Os habitantes de Mogy e redondezas são em geral pobres e suas terras pouco férteis. O algodão é quase o único produto que exportavam. Segundo o que me informaram fazia-se outrora muito assucar nas vizinhanças de Taubaté, mas desde que subiu o preço do café desinteressaram se os lavradores da cana para cuidar dos cafezais (SAINT HILAIRE, citado por GRÍNBERG, 1961:353).

Mas, a partir do final do século XIX, quando se retomou a cultura do algodão, impulsionada agora pela elevação dos preços em função do aumento do consumo da produção brasileira, provocado pela guerra civil norte-americana; e, posteriormente, com a produção cafeeira, sobretudo do Estado de São Paulo, cujos altos volumes exportados impulsionaram ainda mais a produção; e com a entrada de milhões de colonos europeus, que foram responsáveis pela introdução da policultura na agricultura brasileira, a produção agrícola passa apresentar uma

\footnotetext{
${ }^{28}$ Tal situação é bastante semelhante às muitas narradas por Cândido, A. em sua obra Os Parceiros do Rio Bonito, e por Queiroz, Maria Isaura Pereira, em Bairros Rurais Paulistas quando estudaram vários bairros rurais cujos agricultores apresentavam identidade cultural caipira. Já fizemos referência a elas na primeira parte.
} 
grande diversidade de culturas, com destaque para estas culturas, mas também para as culturas do fumo, do amendoim, do arroz e da cana-de-açúcar que passaram a ter uma maior importância. Mas, também na pecuária, houve uma certa diversificação com a introdução de outros rebanhos, como, por exemplo, o ovino.

É evidente que nada disso se fez sem que houvesse ligação com os mercados consumidores. Apesar das más condições das estradas, fato esse lamentado constantemente pelos moradores mogianos ${ }^{29}$, e dos precários meios de transportes, a produção mogiana passa a se beneficiar em função de sua proximidade com a capital paulista, onde já se encontrava em formação o maior mercado consumidor do país, e com a cidade de Santos, de onde embarcava os produtos para o exterior.

Estas transformações, algumas delas verificadas já a partir da década de 30 do século XIX, trouxeram um grande desenvolvimento econômico para o município. A produção agrícola, antes baseada na subsistência, passa de agora em diante a atender, não somente às necessidades da população local, como também a gerar excedentes. Assim, diante dos excedentes, o comércio entre Mogi e outras localidades se fortaleceu e a cidade passou a conhecer um grande crescimento econômico: aumentou-se o número de ruas; a população, que em 1766, era de apenas 2.138 habitantes, aumentou para 14.312 habitantes, em 1870, sendo 1.317 escravos, entre homens, mulheres e crianças e 48 imigrantes homens; o comércio cresceu e as atividades terciárias passaram a representar a principal fonte de rendas.

No ano de 1836, o município já registrava uma imponente produção agropecuária: 8 destilarias que processaram 1.014 canadas (sic) de aguardente; 38 fazendas de café, que produziram 11.237 arrobas; Para as demais culturas,

\footnotetext{
${ }^{29}$ Há dois fatos, particularmente, que mais nos chamaram a atenção: em 29 de janeiro de 1799, um ofício da Câmara, dirigido ao Governador da Capitania informava que a vila não tinha necessidade de abertura de novas estradas, a não ser a reabertura da antiga via que ligava a vila a Santos. Dizia, ainda, que antes se levava apenas um dia até Santos, mas naquela data, em função das condições, se gastavam até três dias pela estrada que se chamava Cubatão do Cardoso. O outro fato ocorreu em 19 de setembro de 1821, quando o Governador de São Paulo enviou um ofício aos Capitães Mores de São José e Mogi, reiterando ordem anterior para o envio de trabalhadores, voluntários ou forçados, para a construção da estrada de Santos. (GRÍNBERG, 1961, págs. $44 \mathrm{e} 48)$.
} 
foram registrados os seguintes totais de alqueires cultivados: a produção da mandioca ocupou 82 alqueires; o feijão, 13.795 alqueires; o arroz, 14.795 alqueires; o algodão em rama, 1.094; o fumo, totalizou 20 arrobas; o azeite de amendoim, 20 medidas e o algodão arbóreo, totalizou 600 varas. A produção pecuária registrada foi a seguinte: rebanho suíno, 501 cabeças; bovino, 67 reses; eqüino, 36 e o ovino, 14 cabeças. (GRÍNBERG, 1961, pág. 56).

E em 1872, a cidade já contava com dezesseis ruas, além de nove largos, três travessas e duas ladeiras. O comércio era constituído por 42 armazéns; 20 lojas de fazendas; 8 alfaiatarias; 5 lojas de aluguel de animais; 9 carpintarias; 6 ferrarias; 2 hotéis; 2 marcenarias; 4 funilarias; 2 tamancarias; 4 sapatarias, além de uma selaria, colchoaria, bilhar, açougue, ourivesaria e serralheria. Possuía, ainda, quatorze fábricas, sendo nove vinícolas, dois curtumes, duas olarias e uma fábrica de cervejas. (Idem, pág. 69).

Já no ano de 1894, a produção agrícola do município registrada, alcançava 1.670 pipas de aguardente; 170 pipas de vinho; 11.000 sacas de farinha de mandioca e 600 quilos de rapadura. E em 1897, a agricultura contava com 200.000 pés de café e 20.000 de videiras; a produção de aguardente chegou a 1.250 pipas de aguardentes e 220 pipas de vinho; 20.000 litros de arroz; 10.000 arrobas de café; 25.000 litros de feijão; 500.000 litros de milho e 200 arrobas de tabaco. (GRINBERG, 1961:83, 84 e 87).

Como se pode perceber, a partir destes três últimos trechos datados de 1836, 1872 e 1894, a economia mogiana, de modo geral, apresentou um grande desenvolvimento econômico, durante o século XIX, particularmente em decorrência do aumento da produção das atividades agrícolas. Em conseqüência disso, também passou a industrializar parte da produção que se destinava aos mercados.

Tais fatores foram ainda mais impulsionados pela proximidade que este município tem em relação à capital paulista. A relação que aí se estabelecia era a de interdependência, ou no máximo a de dependência, mas nunca a de decadência, como defendia ZALUAR, em sua obra Peregrinações pela Província de São Paulo (1860-1861), sobre sua viagem a Mogi das Cruzes, citado por 
GRÍNBERG, logo abaixo. Senão, como explicar o desenvolvimento econômico que foi notório, a partir do século XX em Mogi das Cruzes?

A proximidade em que se acha da capital é sem dúvida uma das causas de sua decadência, pois the absorve esta toda a sua autonomia. É um singular fenômeno que se dá para com certos núcleos do interior na proximidade dos grandes centros. O seu próximo contacto, longe de ser um bem, enfraquece e esteriliza os elementos de progresso local, nestas povoações de subúrbio, que não só definham pela falta dos capitais, que se deslocam no emprego de transações de interesses mais imediato, como pela escassez de braços, que encontram melhores salários nos pontos de maior atividades. A sua maior cultura é a do café, que nos dizem ter tido ultimamente algum desenvolvimento, e os gêneros alimentícios que produz chegam para seu consumo $^{30}$, e não sabemos se exportam para a capital alguns, visto que tanto a cana como o algodão e a aguardente procuram saída naquele mercado ou no grande centro da Côrte, para onde descem os gêneros de exportação em bestas, muares, até a cidade de Santos ou a vila de São Sebastião. (ZALUAR (1860: $\left({ }^{31}\right)$ ) apud GRINBERG, 1961:356/7).

Acima, procuramos apresentar um breve histórico sobre a produção agropecuária de Mogi das Cruzes, baseado em trechos históricos da obra de GRÍNBERG, História de Mogi das Cruzes: Do começo até 1954, a fim de compreendermos o papel que a agricultura desse município desempenhou ao longo de sua história e em que condições histórico-econômicas chegou ao século $\mathrm{XX}$.

Sobre alguma outra obra que pudesse nos ajudar, infelizmente não conseguimos encontrar nenhuma outra que contribuísse melhor que esta de GRÍNBERG. Há até uma razoável quantidade de obras sobre a História de Mogi das Cruzes, mas a maioria se destina apenas a contribuir na elucidação do contrasenso que se formou em torno do fundador do povoado.

A partir dos relatos desta obra, portanto, foi possível compreender que, até o século XVIII, Mogi das Cruzes era uma pequena vila, de casas de taipa,

\footnotetext{
${ }^{30}$ Grifo nosso.

${ }^{31} \mathrm{O}$ autor da citação não indicou o número da página.
} 
isolada e deserta. Somente era ocupada, eventualmente, por ocasião de alguma festividade. Sendo os moradores, quase todos agricultores de culturas de subsistência e criadores de pequenos animais, vivendo numa situação de muita pobreza.

Entretanto, durante o século XIX, com o surto da cultura do algodão, cultura tradicional de seus agricultores; com a produção e exportação do café, que foi responsável pelas imigrações européias, cujos colonos trouxeram novas técnicas de cultivo; com a retomada da cultura da cana-de-açúcar; com a introdução de novas culturas; com a proximidade aos principais mercados nacionais e ao porto de Santos, por onde partiam os produtos para o exterior, a agricultura apresentou um grande desenvolvimento, cujos reflexos se fizeram sentir, sobretudo, na economia urbana. O Comércio se expandiu, a cidade cresceu, a população teve um extraordinário crescimento e a economia terciária passou a ser a principal fonte de renda do município.

A partir das primeiras décadas do século $X X$, a paisagem agrícola mogiana apresenta novas características. A presença de ex-colonos, inicialmente de italianos e espanhóis e, posteriormente de japoneses, que se deslocaram das antigas zonas cafeeiras do interior paulista para a região de Mogi das Cruzes, em busca de pequenas unidades de preços baixos, vai lentamente transformando a paisagem agrícola. Tais trabalhadores teriam reunido recursos, em suas áreas de origem, e buscavam, nas novas áreas, conquistar a sua autonomia econômica.

Mas, houve, também, a migração de muitos camponeses que foram expropriados de suas terras localizadas nas antigas áreas do "cinturão caipira". Acontece que os camponeses, por não terem o título legal das terras que ocupavam por intermédio da posse, acabaram se transferindo para outras áreas, ou porque sofreram expropriação, por parte dos especuladores imobiliários de olho na valorização das terras, ou porque simplesmente abandonaram suas terras, em função da perda de fertilidade do solo. Todo esse processo guarda íntimas relações com a expansão urbana da cidade de São Paulo que, neste início de século, conheceu um intenso processo de metropolização. 
Com a formação e o crescimento da metrópole, sobretudo, impulsionada pela chegada de milhares de imigrantes à capital paulista e seus arredores, novas culturas e técnicas foram introduzidas na agricultura, modificando antigos costumes alimentares, obrigando os agricultores a introduzirem mudanças na organização da produção, e novos modos de vida passaram a ser adotados na sociedade.

Se por um outro lado, esta conjuntura favoreceu o deslocamento de pequenos agricultores para a região de Mogi das Cruzes, por outro, os baixos preços das terras agrícolas (por serem consideradas de baixa qualidade ${ }^{32}$ ), se comparados com as de outras áreas periféricas à metrópole, como Cotia, Vargem Grande, Embu, etc., deste município, se somou aos outros fatores formando um conjunto de possibilidades que atraiu grandes levas de ex-colonos, especialmente de japoneses, e de pequenos agricultores camponeses expropriados, que buscavam pequenas unidades de terras para se instalarem como agricultores autônomos.

SEABRA (1971) afirma que foram os colonos, italianos e espanhóis, os responsáveis pela introdução da cultura de hortaliças nos arredores de São Paulo, no início do século XX e, não os japoneses, como é costume se pensar.

De fato, pelo menos na região de Mogi das Cruzes, acredita-se que o primeiro imigrante japonês tenha sido o agricultor SHIGUETOSHI SUZUKI com sua família, em setembro de 1919, para o bairro de Cocuera no município de Mogi das Cruzes. A partir daí, como afirma GRÍNBERG, "pouco a pouco, centenas e centenas de famílias japonesas passaram a instalar-se no município, trabalhando e produzindo, para constituir-se nessa poderosa força de progresso, que é hoje, indubitavelmente, a colônia japonesa local”. (GRÍNBERG, 1961, pág. 168).

Mas, se por um lado, não foram os colonos japoneses os que introduziram a cultura de hortaliças na agricultura paulista, por outro, foram eles que expandiram e definiram mais claramente o caráter comercial e especulativo de muitas atividades hortifrutigranjeiras, contribuindo de modo decisivo para a

\footnotetext{
${ }^{32}$ Eram chamadas, na época, de terra para japonês, devido a pobreza de seus solos que, geralmente, são sempre encharcadas em função da baixa profundidade do lençol freático.
} 
constituição de um espaço onde tais atividades encontrariam condições propícias para se desenvolver. E com a predominância das culturas de hortaliças, que são em geral verdes, a região passou a ser denominada de cinturão verde ${ }^{33}$.

\section{Mapa da Grande São Paulo: Localização de Mogi das Cruzes}

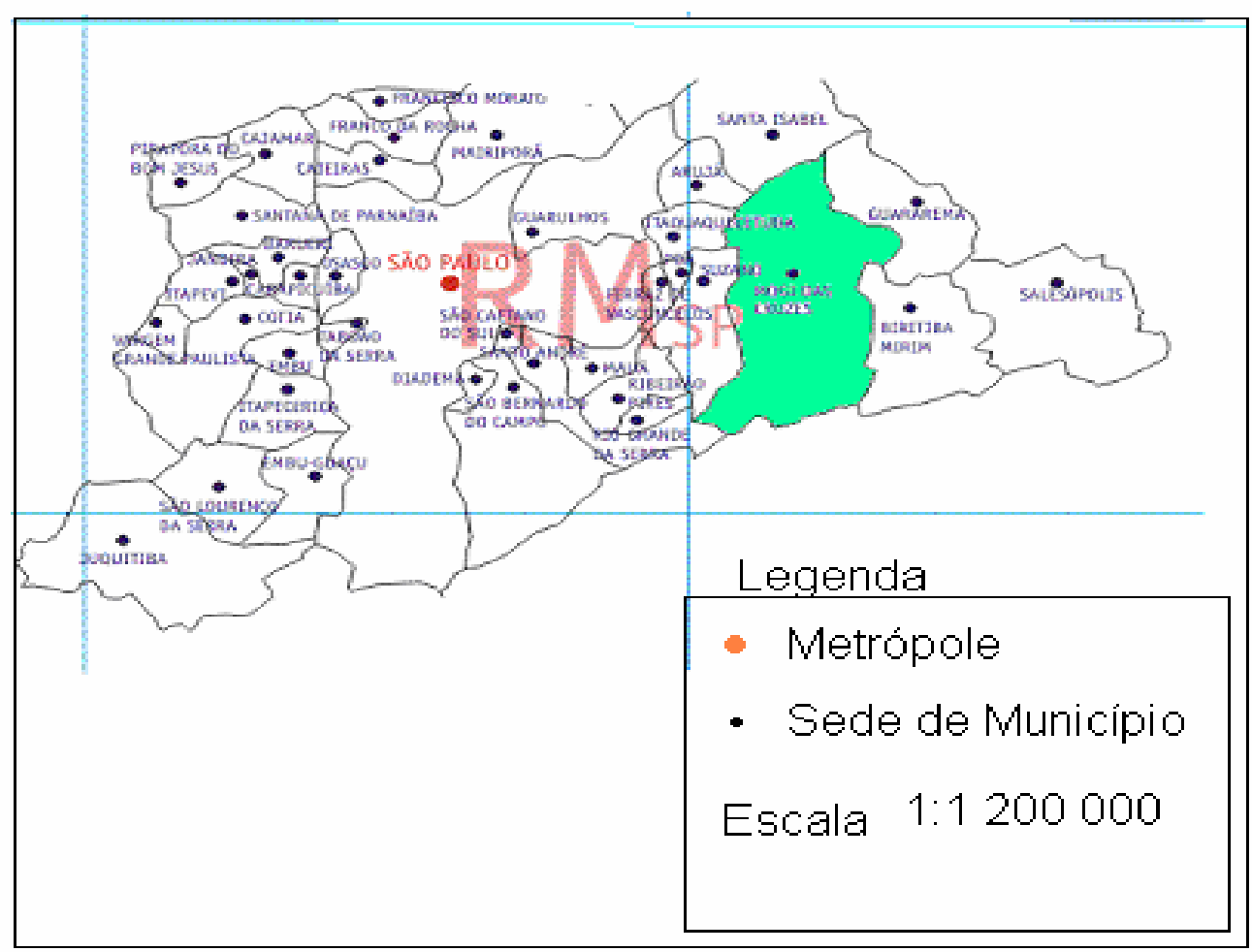

Este termo que foi utilizado, no passado, para designar as áreas onde predominavam as culturas de hortaliças e legumes, sem se considerar as demais culturas existentes. Era de certo modo o que ocorria com a agricultura de dezenas de município que estão circunvizinhos à cidade de São Paulo. De qualquer modo,

\footnotetext{
${ }^{33}$ Este termo que é, provavelmente, uma adaptação equivocada da Teoria de Von Thünnen, foi utilizado, no passado, para designar a área onde havia uma produção de culturas verdes, como as hortaliças e frutas, conjuntamente com a criação de aves e produção de ovos. A partir disso, o termo foi popularizado nacionalmente e, ainda hoje, é utilizado para caracterizar a paisagem agrária de regiões como a de Mogi das Cruzes, Vargem Grande Paulista, Sorocaba etc.

"Segundo o Departamento de Estatística do Estado de São Paulo, o Cinturão verde compreenderia os municípios de: Barueri, Caieiras, Cajamar, Cotia, Diadema, Embu, Ferraz de Vasconcelos, Franco da Rocha, Guarulhos, Itapecerica da Serra, Itapevi, Itaquaquecetuba, Mairiporã, Mauá, Mogi das Cruzes, Pirapora do Bom Jesus, Poá, Ribeirão Pires, Salesópolis, Santana do Parnaíba, Santo André, São Bernardo do Campo, São Caetano do Sul, São Paulo, Suzano, Taboão da Serra, tomando como base a divisão administrativa de 195964. Já em 1967, a Proagri colocava uma tabela de dados do Cinturão Verde que compreendia os seguintes municípios: Atibaia, Arujá, Bom Sucesso, Casa Grande, Embu, Guarulhos, Itaquera, Itapecerica da Serra, Mairiporã, Mauá, Mogi das Cruzes, Parelheiros, Taipas, Taboão da Serra, Ribeirão Pires, Santo André, Santo Amaro e Suzano". (SOARES, Raul Nina Guterres, 1966, apud DE LA CORTE, 1985, pág. 210).
} 
o termo se popularizou e até os dias atuais muitos municípios ainda são considerados como integrantes do cinturão verde.

Hoje, grande parte destes municípios teve a maioria de suas áreas agrícolas tomadas pela urbanização. Muitos são centros comerciais e industriais sem ou quase nenhuma importância agrícola. Somente, um pequeno número destes municípios, como Piedade, Ibiúna, Biritiba Mirim, Suzano e Mogi das Cruzes, é que continua com produção agrícola significativa ${ }^{34}$, apesar de alguns, também, serem centros comerciais ou industrializados e estarem inseridos no espaço de consumo e expansão metropolitano.

Apesar da grande produção de hortaliças e de legumes, que continua a ser produzida nestes municípios, não se deveria mais utilizar o termo frutigranjeiro para caracterizá-los. Isto porque, as áreas de produção das culturas de frutas e de flores, e a criação de frangos em granja para produção de ovos, que caracterizam os termos fruti e granjeiro, respectivamente, foram praticamente, com exceção do município de Mogi das Cruzes, destinadas à ampliação das áreas de produção de hortaliças e legumes. No caso das granjas, algumas áreas com as antigas instalações, foram arrendadas a pequenos produtores, chineses e coreanos, que migraram recentemente para Mogi das Cruzes e se ocuparam com a produção de cogumelos. $^{35}$

A exceção, portanto, fica por conta do município de Mogi das Cruzes, que além da grande produção de hortaliças e legumes, mantém uma importante produção de frutas, caqui e de nêspera; de flores que, a partir da construção de um laboratório por um grupo de produtores, se especializou no cultivo de orquídeas, chegando hoje à exportação; e criação de codornas para produção de ovos para reprodução.

Para nós, há a necessidade de se verificar, atualmente, quais são os produtos agrícolas destes municípios e qual é a porcentagem deles nos mercados

\footnotetext{
${ }^{34}$ As causas disso, particularmente para o município de Mogi das Cruzes, e, genericamente, para os municípios que compõem a região geográfica desse município, serão abordadas no desenvolvimento deste trabalho, quando trataremos das questões ambientais na última parte.

${ }^{35}$ A produção é bastante significativa, pois a região de clima predominantemente úmido favorece a cultura que se estabeleceu nas instalações das antigas granjas.
} 
da Região Metropolitana de São Paulo, para se saber quais são os municípios que, ainda, integram esta região agrícola específica.

Mas, ao mesmo tempo em que a cidade de São Paulo se consolidava como metrópole nacional, atraindo investimentos públicos e privados, nacionais e internacionais, e trabalhadores das áreas rurais para formação do mercado de trabalho, ela se constituía como o maior mercado consumidor do país, cuja necessidade de se garantir o abastecimento de gêneros alimentícios era prioritária.

DE LA CORTE (1985), em sua obra de doutoramento, Contribuição ao Estudo do Abastecimento da Cidade de São Paulo em Produtos Hortifrutícolas, referindo-se a um documento, de 1967, da Comissão Interestadual da Bacia Paraná-Uruguai, destaca a seguinte citação:

A constatação da existência, ao redor da Capital, de um anel constituído de pequenos produtores voltados para o cultivo de legumes, e responsáveis pelo suprimento diário de verduras à população paulistana, anel este já denominado de 'Cinturão Verde', levou o Governo do Estado, através do Decreto no 45.131 de 12 de agosto de 1965, a instituir o Serviço Rural da Capital. Estabelecendo e reorganizando o Serviço de Fomento Agropecuário da Capital, aquele decreto reuniu e estabeleceu a coordenação, para o mesmo objetivo, das seguintes Casas da Lavoura: Capital, Cotia, Franco da Rocha, Guarulhos, Itapecerica da Serra, Mairiporã, Moji das Cruzes, Piedade, Santo André, São Bernardo do Campo, Santa Izabel, São Roque, Ibiúna, Suzano, Guararema, Salesópolis, Ribeirão Pires, Mauá, Santana do Parnaíba e Itaquaquecetuba. (Cf. DE LA CORTE, 1985, pág. 210).

HESPANHOL (2004) et alli, afirma que para aumentar a oferta de alimentos no mercado paulista e a racionalidade na distribuição, o governo estadual, Lucas N. Garcez, criou em 1952 o Serviço de Fomento Agropecuário da Capital. Para dinamizá-lo, foi constituído, no mesmo ano, o Cinturão Verde através do Plano Quadrienal de Administração que, por sua vez, seria responsável pela criação de Casas de Agricultura (sendo uma delas em Mogi das Cruzes), a fim de prestar assistência técnica aos produtores rurais, e pelo Centro Estadual de 
Abastecimento - CEASA (posteriormente passou ao controle dos CEAGESP), na cidade de São Paulo, que veio a ser inaugurado no ano de 1966.

Outros dois fatos vieram a se somar a estes na consolidação da área do Cinturão Verde: o primeiro, ocorreu em 7 de abril de 1952, quando realizou-se, em Mogi das Cruzes, a primeira Festa do Caqui sob a organização da colônia japonesa com o apoio da prefeitura local, consolidando a região como a maior produtora nacional dessa fruta, e o segundo, ocorreu em junho, do mesmo ano, quando o deputado estadual Derville apresentou à Assembléia Legislativa de São Paulo um projeto de lei, que ao ser aprovado, obrigava a Secretaria de Agricultura deste estado a criar um Posto de Mecanização Agrícola no município de Mogi das Cruzes.

Porém a expansão do setor de alimentos, incluindo-se o hortifrutigranjeiro, aconteceria de forma mais significativa com a criação do Estatuto da Terra, em 30 de novembro de 1964, e com o início do processo de industrialização da agricultura nacional, promovida pelos governos militares.

Com a implantação do regime militar, em 1964, adota-se de uma política desenvolvimentista com forte influência ${ }^{36}$ do governo dos Estados Unidos, que visava aumentar o seu poderio econômico mediante a venda de insumos e máquinas agrícolas, através das determinações da Law and Development e da Modernization of Law, cujas orientações destinavam-se aos programas de assistência econômico-comercial aos países do chamado Terceiro Mundo. (MORAES SILVA, 2004, pág. 20).

A partir disso, os militares seguiram fielmente as tais determinações e, logo em 1964, criaram o Estatuto da Terra, através da Lei $n^{\circ} 4.504$, pela qual se visava, prioritariamente, a modernização do campo mediante o aumento da produção e da produtividade. A partir daí, como afirma MORAES SILVA, "a paisagem rural mudou radicalmente. Milhares de máquinas, tratores e insumos agrícolas substituíram paulatinamente a maneiras de produzir até então existentes. A modernização da agricultura significou, basicamente, o aumento e a consolidação da expansão capitalista, cujo resultado foi a chamada

\footnotetext{
${ }^{36}$ Esta influência foi chamada Aliança para o Progresso, entre os dois países.
} 
industrialização do campo, com a presença de grandes empresas nacionais e internacionais e a concentração acelerada da terra e da renda". (Idem, pág. 21).

Com estas medidas aumentou-se a produção de alimentos $\mathrm{e}$ as atividades hortifrutigranjeiras passaram a conhecer um período de grande produtividade, tal fato também contribuiu para o aumento da produção da área de hortaliças do "Cinturão Verde", especialmente a do município de Mogi das Cruzes, por este sediar os órgãos técnicos implantados na região, além de possuir o maior número de cooperativas agrícolas ${ }^{37}$ e de agricultores.

O grupo de agricultores que pesquisamos está localizado em um dos bairros rurais do município de Mogi das Cruzes, principal centro produtor de hortaliças do cinturão verde. Sua produção é considerada a mais expressiva, pois é a principal responsável pelo abastecimento de hortaliças para os mercados consumidores da Região Metropolitana de São Paulo, Baixada Santista, Vale do Paraíba e, um pouco menos, para os mercados das Regiões Metropolitanas do Rio de Janeiro e Belo Horizonte.

O Censo Agropecuário de 1995, realizado pelo IBGE, apontou que o município de Mogi das Cruzes possuía uma área agrícola de 27.323 hectares e um total de 1.458 estabelecimentos.

A Secretaria de Agricultura e Abastecimento do Estado de São Paulo realizou em 1995/6, um levantamento sobre a produção agrícola das unidades de produção dos municípios paulistas (Projeto LUPA ${ }^{38}$ ). Neste levantamento, o município de Mogi das Cruzes apresentava uma produção agrícola bastante diversificada: a alface era produzida por 216 estabelecimentos; repolho por 163; brócolis por 138; couve-flor por 118; pimentão por 34; beterraba por 85; salsa por 69; cebolinha por 57; coentro por 55; pepino por 42; jiló por 37 ; berinjela por 27 ; espinafre por 20 e chicória por 12; além de outras culturas como eucalipto, caqui, milho, e etc.

\footnotetext{
${ }^{37}$ A contribuição que as cooperativas deram ao abastecimento de hortaliças para os mercados paulistas, bem como o sistema utilizado e os fatores que levaram ao encerramento de suas atividades neste município, serão analisados no próximo item deste capítulo.

${ }^{38}$ http://www.cati.sp.gov.br/novacati/index.php - 07/05/2004.
} 
Em 21 de outubro de 1997, foi divulgado pela imprensa local, um documento denominado de "PERFIL DA AGRICULTURA EM MOGI DAS CRUZES ${ }^{39}$ ", que foi realizado pela Assessoria de Imprensa do Sindicato Rural, sobre a produção do município. O documento apontava o município de Mogi das Cruzes como o maior produtor nacional de alface, com $40 \%$ de participação nacional; caqui, com 50\%; nêspera e cogumelo com $80 \%$ cada. O documento trazia, também, a quantidade da produção de hortaliças do município por estação do ano: no verão a produção era de 319 toneladas/dia e no inverno a produção subia para 425 toneladas/dia. Já nas estações da primavera e outono, a produção era ainda maior, ficando entre 750 e 800 toneladas/dia e destacava a região do Alto Tietê como sendo a responsável por $25 \%$ do abastecimento do mercado paulista.

Conforme o Secretário Municipal de Agronegócios - no período 2004 a 2007, o senhor TAKASHI, a área rural do município de Mogi das Cruzes pode ser dividida atualmente segundo suas culturas:

\footnotetext{
${ }^{39}$ O Sindicato Rural de Mogi das Cruzes estava, na época, sob a presidência do então deputado estadual Jungi Abe, do PSDB, eleito prefeito do município por mais de um mandato.
} 
Áreas Produtoras, Produtos e Mercados da Produção Agrícola de Mogi das Cruzes em 2005.

\begin{tabular}{|c|c|c|}
\hline Produtos & $\begin{array}{l}\text { Distritos ou Bairros } \\
\text { Rurais Produtores }\end{array}$ & Mercados Consumidores \\
\hline $\begin{array}{l}\text { Hortaliças: } \\
\text { - agrião, alface, brócolis, } \\
\text { catalunha, cebolinha, } \\
\text { couve, escarola, rúcula, } \\
\text { salsa, coentro,almeirão, } \\
\text { manjericão, espinafre, } \\
\text { repolho, e etc. }\end{array}$ & $\begin{array}{l}\text { Cocuera, Jundiapeba, } \\
\text { Taiaçupeba, Pindorama. }\end{array}$ & $\begin{array}{c}\text { Grande São Paulo, Vale do } \\
\text { Paraíba, Baixada Santista, } \\
\text { Litoral Norte Paulista e Rio } \\
\text { de Janeiro. }\end{array}$ \\
\hline $\begin{array}{l}\text { Legumes: } \\
\text { - abobrinha, beterraba, } \\
\text { cenoura, pimentão, nabo, } \\
\text { etc. }\end{array}$ & $\begin{array}{l}\text { Cocuera, } \\
\text { Jundiapeba, } \\
\text { Taiaçupeba e } \\
\text { Pindorama. }\end{array}$ & Idem. \\
\hline $\begin{array}{l}\text { Frutas: } \\
\text { - caqui e nêspera }\end{array}$ & $\begin{array}{l}\text { Capela, Vila } \\
\text { Moraes, Cocuera e } \\
\text { Biritiba Ussú. }\end{array}$ & $\begin{array}{l}\text { Grande São Paulo e } \\
\text { interior paulista. }\end{array}$ \\
\hline Cogumelo & $\begin{array}{c}\text { Botujuru, } \\
\text { Taiaçupeba, } \\
\text { Pindorama e } \\
\text { Cocuera. }\end{array}$ & $\begin{array}{l}\text { Grande São Paulo, } \\
\text { interior paulista, e } \\
\text { Grande Rio de Janeiro. }\end{array}$ \\
\hline $\begin{array}{l}\text { Flores: } \\
\text { - orquídeas }\end{array}$ & Itapety, & $\begin{array}{l}\text { Grande São Paulo, } \\
\text { interior paulista, outras } \\
\text { cidades do Brasil e } \\
\text { Argentina. }\end{array}$ \\
\hline $\begin{array}{l}\text { Flores: } \\
\text { - crisântemo }\end{array}$ & Pindorama & Idem \\
\hline Cordonas & $\begin{array}{c}\text { Pindorama, Porteira } \\
\text { Preta. }\end{array}$ & Estado de São Paulo. \\
\hline Pinto de um dia & Cocuera & Idem \\
\hline Ovos & Cocuera & Idem \\
\hline
\end{tabular}

Fonte: Dados da entrevista com o senhor TAKASHI, em 22/07/05.

Para uma avaliação parcial de quanto a produção deste município participa no mercado paulistano, consultamos o CEAGESP, que é o principal centro de distribuição de hortaliças, com cerca de $60 \%$ do volume comercializado no país, que nos forneceu os volumes comercializados em $2004^{40}$, segundo a procedência, dos municípios cuja produção apresenta tradicionalmente maior

\footnotetext{
${ }^{40}$ Não foi possível levantar a seqüência dos cinco últimos anos, como queríamos, por que o CEAGESP sofreu uma grande inundação e perderam-se os dados que se encontravam armazenados em micro-computadores.
} 
participação no mercado metropolitano de São Paulo, ou seja, Ibiúna, Piedade, Campinas, Sorocaba, Suzano, Biritiba Mirim e Mogi das Cruzes.

Procedência das Hortaliças Comercializadas na CEAGESP durante $o$ ano de 2004. (em toneladas)

\begin{tabular}{|l|r|r|r|r|r|r|r|}
\hline Produtos & Ibiúna & Piedade & Campinas & Sorocaba & Suzano & B. Mirim & $\begin{array}{c}\text { Mogi das } \\
\text { Cruzes }\end{array}$ \\
\hline Ag & 97,3 & 42,9 & 5,1 & 15,8 & 98,5 & $\mathbf{1 . 3 5 2 , 8}$ & 860,2 \\
\hline AM & $1.367,0$ & $\mathbf{3 . 4 9 9 , 5}$ & 40,4 & 5,6 & 1,9 & 98,8 & 108,4 \\
\hline AC & $\mathbf{2 . 9 3 0 , 4}$ & $1.133,8$ & 482,2 & 101,7 & 27,4 & 238,0 & 529,3 \\
\hline AL & 993,9 & 547,7 & 30,7 & 10,5 & 4,3 & 57,8 & 564,1 \\
\hline AR & 44,3 & $\mathbf{7 7 , 3}$ & 5,6 & 0,2 & 0,4 & 59,1 & 15,3 \\
\hline BcF & 421,9 & $\mathbf{9 4 3 , 0}$ & ni & 3,1 & 4,2 & 18,0 & 55,0 \\
\hline Br & $\mathbf{4 . 7 6 8 , 1}$ & $2.311,1$ & 3,8 & 174,5 & 0,9 & 65,8 & 192,9 \\
\hline Ca & $\mathbf{2 8 3 , 3}$ & 104,2 & 0,7 & 1,7 & 3,5 & 5,5 & 17,7 \\
\hline Ce & 147,7 & $\mathbf{3 2 4 , 8}$ & 4,8 & 15,3 & 7,2 & 6,5 & 32,6 \\
\hline CcF & 196,3 & $\mathbf{6 2 6 , 8}$ & 0,5 & 0,3 & 0,9 & 73,2 & 18,9 \\
\hline Co & $\mathbf{1 . 5 4 9 , 5}$ & $1.069,3$ & 6,9 & 336,5 & 6,2 & 40,1 & 77,4 \\
\hline CF & $\mathbf{2 . 2 3 2 , 6}$ & 318,1 & 4,7 & 522,1 & 2,6 & 13,1 & 94,1 \\
\hline Es & $\mathbf{1 . 3 9 3 , 8}$ & 421,6 & 50,5 & 14,8 & 7,8 & 91,2 & 580,8 \\
\hline Na & $\mathbf{7 2 3 , 0}$ & $\mathbf{1 . 2 7 9 , 1}$ & $\mathrm{Ni}$ & 61,1 & 1,0 & 37,9 & 26,8 \\
\hline Ra & 310,7 & $\mathbf{1 . 3 7 0 , 5}$ & 0,6 & 51,4 & 0,9 & 90,9 & 113,1 \\
\hline Re & $\mathbf{3 7 . 2 7 6 , 6}$ & $9.334,2$ & 2,2 & $2.134,1$ & 199,9 & 456,1 & $1.353,5$ \\
\hline Ru & $\mathbf{6 1 1 , 3}$ & $\mathbf{3 6 5 , 0}$ & 4,3 & 19,3 & 2,6 & 52,2 & 34,7 \\
\hline As & $\mathbf{1 . 0 6 1 , 5}$ & $\mathbf{5 2 2 , 0}$ & 2,3 & 25,8 & 8,1 & 6,2 & 27,1 \\
\hline Total & $\mathbf{5 6 . 4 0 9 , 2}$ & $\mathbf{2 4 . 2 9 0 , 9}$ & $\mathbf{6 4 5 , 3}$ & $\mathbf{3 . 4 9 3 , 8}$ & $\mathbf{3 7 8 , 3}$ & $\mathbf{2 . 7 6 3 , 2}$ & $\mathbf{4 . 7 0 1 , 9}$ \\
\hline
\end{tabular}

Fonte: Seção de Economia e Desenvolvimento do CEAGESP-SP. (*ni - não teve entrada ou não informou - os dados destacados referem aos maiores volumes)

\section{LEGENDA}

\begin{tabular}{|c|c|c|c|c|c|c|c|c|}
\hline Ag & AM & AC & AL & AR & BcF & Br & Ca & Ce \\
\hline Agrião & $\begin{array}{c}\text { Alface } \\
\text { americana }\end{array}$ & $\begin{array}{c}\text { Alface } \\
\text { crespa }\end{array}$ & $\begin{array}{c}\text { Alface } \\
\text { lisa }\end{array}$ & $\begin{array}{c}\text { Alface } \\
\text { romana }\end{array}$ & $\begin{array}{c}\text { Beterraba } \\
\text { cl folhas }\end{array}$ & Brócolis & Catalonha & Cebolinha \\
\hline CcF & Co & CF & Es & Na & Ra & Re & Ru & As \\
\hline $\begin{array}{c}\text { Cenoura } \\
\text { c/ folha }\end{array}$ & Coentro & $\begin{array}{c}\text { Couve- } \\
\text { flor }\end{array}$ & Escarola & Nabo & Rabanete & Repolho & Rúcula & Salsa \\
\hline
\end{tabular}

Verifica-se pelos dados da tabela que do total de volume comercializado pelo CEAGESP, que em 2004 foi de 92.682,6 toneladas, os maiores volumes 
foram procedentes dos municípios de Ibiúna, com a participação de $60,8 \%$ e Piedade, com $26,2 \%$, totalizando $87 \%$ do volume anual. Os demais municípios participaram conjuntamente com apenas $13 \%$, sendo que a produção de Mogi das Cruzes correspondeu apenas $5 \%$ do total.

Verificaremos agora os dados do Instituto de Economia Agrícola, para 2004, para compará-los aos de procedência da CEAGESP-SP.

\begin{tabular}{|c|c|c|c|c|c|c|}
\hline \multicolumn{7}{|c|}{$\begin{array}{l}\text { Produção por Município Segundo os Escritórios de Desenvolvimento } \\
\text { Rural de Mogi das Cruzes, Sorocaba e São Paulo para o Ano de } 2004 .\end{array}$} \\
\hline EDR & \begin{tabular}{|c|} 
Abobrinha \\
$\mathrm{R} \$ 9,84$ \\
Eng. $10 \mathrm{~kg}$
\end{tabular} & $\begin{array}{c}\text { Alface } \\
\mathrm{R} \$ 6,54 \\
\text { Eng. } 10 \mathrm{~kg}\end{array}$ & $\begin{array}{c}\text { Beterraba } \\
\mathrm{R} \$ 8,58 \\
\mathrm{C} \times 21 \mathrm{~kg}\end{array}$ & $\begin{array}{c}\text { Cenoura } \\
\mathrm{R} \$ 13,81 \\
\mathrm{Cx} \mathrm{K} 22 \mathrm{~kg}\end{array}$ & \begin{tabular}{|c|} 
Pimentão \\
$\mathrm{R} \$ 6,13$ \\
$\mathrm{cx} .11 \mathrm{~kg}$
\end{tabular} & $\begin{array}{c}\text { Repolho } \\
\text { R } \$ \\
\text { Sc } 25 \mathrm{~kg}\end{array}$ \\
\hline ai & $\begin{array}{r}147.050 \\
(15,9 \%)\end{array}$ & $\begin{array}{r}2.817 .335 \\
(49,2 \%)\end{array}$ & $\begin{array}{r}1.423 .968 \\
(32,0 \%)\end{array}$ & $\begin{array}{r}1.475 .625 \\
(18,7 \%)\end{array}$ & $\begin{array}{r}720.818 \\
(\mathbf{4 4 , 7} \%)\end{array}$ & $\begin{array}{r}1.563 .840 \\
(14,9 \%)\end{array}$ \\
\hline rocaba & $\begin{array}{l}709.500 \\
(76,7 \%)\end{array}$ & $\begin{array}{r}1.783 .200 \\
(31,0 \%) \\
\end{array}$ & $\begin{array}{r}2.646 .515 \\
(59,5 \%)\end{array}$ & $\begin{array}{r}6.389 .321 \\
(81,1 \%)\end{array}$ & $\begin{array}{l}457.091 \\
(28,3 \%)\end{array}$ & $\begin{array}{r}7.381 .200 \\
(\mathbf{7 0 , 3} \%) \\
\end{array}$ \\
\hline 5. Paulo & $\begin{array}{r}68.460 \\
(7,4 \%)\end{array}$ & $\begin{array}{r}1.135 .704 \\
(19,8 \%)\end{array}$ & $\begin{array}{r}378.813 \\
(8,5 \%)\end{array}$ & $\begin{array}{r}488.603(6,2 \\
\%)\end{array}$ & $\begin{array}{l}433.281 \\
(27,0 \%)\end{array}$ & $\begin{array}{r}1.555 .236 \\
(14,8 \%)\end{array}$ \\
\hline Total & 925.010 & 5.736 .239 & 4.449 .296 & 7.864 .946 & 1.611 .19 & 10.500 .276 \\
\hline
\end{tabular}

A análise dos dados para o ano de 2004, fornecidos pelo IEA-SP, demonstra uma clara predominância da produção de Sorocaba, em certos produtos, sobre os EDR de Mogi e de São Paulo. A participação deste EDR para o ano de 2004 foi de $76,7 \%$ para o produto abobrinha; $59,5 \%$ para o produto beterraba; $81,1 \%$ para o produto cenoura e $70,3 \%$ para o produto repolho. O EDR de Mogi (que compreende além dele, Suzano e Biritiba Mirim) contribuiu com $49,2 \%$ do mercado de alface e $44,7 \%$ para o produto pimentão, enquanto a produção do EDR de São Paulo ficou bem abaixo dos dois EDR. Ou seja, a região de Sorocaba, que inclui os municípios de Ibiúna e Piedade, assumiu a liderança no abastecimento de hortaliças para os mercados paulistanos, conforme se pode ver pelas procedências de 2004 da CEAGESP e pelos dados fornecidos pelo IEASP.

Os agricultores da região do cinturão verde de Sorocaba produziram, em 2004, maiores volumes de hortaliças e apresentaram maior participação no mercado paulistano que os agricultores de Mogi das Cruzes. Pode ser que uma 
das razões dessa perda momentânea da liderança, seja explicada pelos altos índices pluviométricos que caíram sobre a região durante o verão de 2003/2004, os quais deixaram algumas localidades alagadas durante um longo período.

Ao se analisar os dados do mesmo IEA-SP para os últimos cinco anos, de 2000 a 2004, fica evidente a maior produção e participação, com exceção para os produtos abobrinha e repolho, dos agricultores de Mogi das Cruzes para os mercados paulistanos, exceto o ano de 2000, o qual revela índices percentuais muito similares aos de 2004.

\section{2 - A contribuição das Cooperativas}

Neste segundo tópico, apoiamos nossas análises em dois importantes estudos, ambos do mesmo autor e desenvolvidos em anos diferentes da mesma década de 1970, quando ainda as maiores cooperativas atuavam fortemente na distribuição de alimentos na cidade de São Paulo, sendo imprescindíveis na abordagem deste tema. Trata-se de Vargem Grande: Organização e Transformação de um Setor do Cinturão-Verde, publicado em 1971, e As Cooperativas Mistas do Estado de São Paulo, publicado em 1977, por MANOEL GUIMARÃES SEABRA.

Apesar da importante contribuição sobre toda a estrutura da organização das cooperativas, que SEABRA nos concedeu, com seus estudos, nós vamos nos restringir apenas às análises sobre a estrutura da rede de comercialização, venda e compra, das cooperativas que tiveram a maior existência e que atuavam nos municípios que formavam a área denominada de "Cinturão Verde".

As cooperativas do Estado de São Paulo, segundo estes estudos, surgiram da necessidade de os agricultores tentarem resolver os problemas que vinham enfrentando com relação à comercialização, que se traduzia, basicamente, no controle de preços pelos intermediários e na precariedade das estradas.

Todas as famílias dedicam-se à lavoura e sentiam a necessidade de se unirem a fim de se salvaguardarem dos grandes prejuízos, pois todos os que levavam suas produções ao mercado estavam sujeitos às ofertas abusivas e preconcebidas dos intermediários. Além dessa desvantagem, o 
tempo que eles perdiam com o transporte individual era muito grande, pois, para colocar os seus produtos no mercado de São Paulo, tinham que sair de suas casas ao entardecer com o caminhão carregado para somente retornar na tarde do dia seguinte. (Cf. SEABRA, 1977, pág. 62).

Essa conjuntura, então, passa a favorecer a expansão do cooperativismo no Estado de São Paulo. Muitas das cooperativas foram criadas por iniciativa dos agricultores japoneses que, inicialmente, fundavam associações de agricultores e, quando passavam a receber um certo número de associados, eram transformadas em cooperativas. $\mathrm{E}$ isso se dava num curto espaço de tempo, porque os problemas eram estruturais e demandavam uma maior ingerência.

Desse modo, as cooperativas do Estado de São Paulo surgem como uma forma de se organizar a produção das mercadorias, em função dos problemas comuns aos agricultores japoneses, relacionados aos custos, à concorrência e aos transportes. Mas, também, pode-se compreender como uma bandeira de luta, um abrigo, contra a subordinação em que estavam submetidos por parte dos intermediários, que tudo faziam para dominar os preços das mercadorias.

A quantidade de cooperativas que foram criadas no estado de São Paulo e, particularmente, na região de Mogi das Cruzes nos dá uma idéia da situação dos agricultores e da pressa que havia em resolver os problemas e a vontade que cada um tinha em organizar sua vida econômica, criando para tanto instituições, como as cooperativas. (SEABRA, 1977, pág. 260). Mas, também, nos permite dizer que os agricultores tinham alguma noção de que não conseguiriam resolvêlos isoladamente, daí a opção por uma instituição que congregasse todos em torno dos problemas comuns.

SEABRA afirma que entre 1933 e 1966 foram fundadas doze cooperativas somente no município de Mogi das Cruzes. As maiores cooperativas que atuaram nesse município foram criadas anteriormente a este período: a Cooperativa Agrícola de Cotia, em 1927; a Cooperativa Agrícola Central SulBrasil, em 1929, ambas com sedes na cidade de São Paulo, e a Cooperativa Agrícola Mista de Mogi das Cruzes, com sede na cidade de Mogi das Cruzes, que teve sua criação em 1931, logo após a criação da Associação de agricultores japoneses que lhe dera origem. 
As cooperativas Central Sul-Brasil e de Cotia, foram as duas que mais se desenvolveram em termos gerais (tecnológicos, administrativos, logísticos, etc.); as que mais expandiram suas áreas de atuação, inclusive para outros estados, e foram as que tiveram maior longevidade superando as demais e, inclusive, a Cooperativa Mista de Mogi das Cruzes, na organização da comercialização, na distribuição da produção e na quantidade de pontos de vendas.

As razões, segundo SEABRA, da grande expansão das cooperativas de Cotia e Sul-Brasil, estavam ligadas, de início, "ao fato de trabalharem como associados produzindo gêneros alimentícios, sobretudo horti-fruti-granjeiros, para o mercado interno e, particularmente, ao fato de se terem sediado dentro do principal mercado consumidor paulista e terem tido acesso ao mercado carioca". (SEABRA, 1977, pág. 260).

E por fim, porque elas tiveram como sede a cidade de São Paulo, cujo Estado apresentava um grande espaço rural a ser conquistado e que contava com dezenas de municípios com milhares de agricultores de ascendência japonesa que almejavam organizar melhor sua vida econômica, possibilitando, assim, condições para que as cooperativas pudessem aumentar seus quadros associativos.

E mais, ainda, há de se considerar, conforme lembra SEABRA, que as cooperativas foram criadas para "coordenar o conjunto das atividades econômicas de seus associados, estas cooperativas, desde cedo, passaram a operar em vários setores: compras, vendas, crédito e diversos outros de fomento agropecuário, transportes, assistência social, etc., rotulados habitualmente de serviços de utilização mútua”. (SEABRA, 1977, pág. 261).

A maioria das cooperativas, entretanto, teve apenas uma existência muito curta. As causas da existência efêmera de muitas cooperativas, não apenas as mogianas como também as paulistas, paranaenses, etc., estão ligadas aos mesmos problemas que toda cooperativa de um modo ou de outro acabaria apresentando.

SEABRA (1977) verificou que as cooperativas localizadas nos municípios vizinhos à cidade de São Paulo, que exportavam, passaram a apresentar 
problemas em suas atividades causados pela diminuição da exportação durante a Segunda Guerra Mundial, os quais inviabilizaram suas atividades. Posteriormente, os problemas com a aplicação da nova Lei cooperativista, que suspendeu as vantagens fiscais, a partir de 1967, provocando uma crise em todas as organizações cooperativistas, a qual foi responsável pela extinção de muitas pequenas cooperativas, se somaram às dificuldades relacionadas aos transportes; à ação dos intermediários e a cobrança de impostos que agravaram ainda mais a situação, formando uma conjuntura que cedo ou mais tarde inviabilizariam as atividades das pequenas cooperativas, por não disporem ainda de uma estrutura mais solidificada.

(...) sem os favores fiscais, a crise manifestou-se mais agudamente. Sem as vantagens das isenções fiscais, estas cooperativas não conseguem vencer a concorrência das firmas comerciais e o seu movimento vai-se tornando cada vez menor e os prejuízos vão-se avolumando. (SEABRA, 1977, pág. 75).

Das cooperativas mogianas, isto é, com sede em Mogi das Cruzes, a que teve maior existência foi a Cooperativa Agrícola Mista de Mogi das Cruzes. O seu processo de fundação foi similar ao processo de fundação das grandes cooperativas do estado de São Paulo. Em 1926, um grupo de imigrantes japoneses moradores nos bairros de Cocuera e Caputera, fundaram uma associação japonesa. Em 1931, criaram uma liga para venda em cooperação de produtos hortifrutigranjeiros e, em 1933, transformaram a liga na Cooperativa Agrícola Mista.

O fato, que talvez tenha mais contribuído para o aparecimento de cooperativas em vários lugares das áreas de colônias japonesas próximas à metrópole, tem ligação direta com os problemas que os produtores enfrentavam com a comercialização. Muitos produtores, por vezes, com a ajuda do governo japonês, passaram a se organizar em associações que mais tarde viriam a se transformar em cooperativas agrícolas. O enfrentamento deste problema, cujos prejuízos tenderiam ao agravamento de dificuldades econômicas, senão à falência de muitos agricultores, teve como bandeira de luta a criação de associações cooperativistas, por duas razões: primeira, a organização em cooperativas teria o 
apoio financeiro do governo japonês ${ }^{41}$, já que essa iniciativa era de interesse coletivo e, segunda, o sistema de vendas em cooperativas consistia no estabelecimento de entrepostos nos mercados paulista e carioca, os quais teriam revendedores exclusivos, o que garantia aos agricultores, pelo menos tecnicamente, um meio de controlar melhor os preços dos produtos, evitando assim o seu aviltamento.

Mas, se por um lado, esta medida concorria para evitar o aviltamento dos preços, por outro, ela não impedia a concorrência entre os distribuidores nos mercados em que operavam as cooperativas e nem resolvia os problemas com a comercialização.

Um caso que merece destaque foi o que ocorreu em 1933: durante esse ano, as principais áreas produtoras de tomates, Itaquera, Suzano e Mogi das Cruzes, registraram uma superprodução. Em decorrência disso, surgiram vários problemas de comercialização e de concorrência entre os comerciantes que controlavam os mercados paulista e carioca, a ponto de exigir a interferência do governo japonês, através do seu Consulado no Brasil.

Para amenizar a crise, o Consulado japonês interveio e concluiu-se um acordo que alterava e estabelecia uma nova organização das áreas de atuação das cooperativas: a C.A. de Cotia deveria alterar sua área de ação legal ${ }^{42}$ para outros municípios, inclusive Mogi das Cruzes e Suzano, ficando com o mercado paulista e a C.A. Mista de Mogi das Cruzes, que fora criada neste mesmo ano, ficaria com o mercado carioca.

A intervenção do Consulado japonês para evitar uma maior crise e o acordo afirmado entre as cooperativas, serviram para despertar o desejo de se firmar um acordo para criar uma federação de cooperativas, visando, dessa forma, evitar futuros conflitos.

\footnotetext{
${ }^{41}$ Uma parte considerável da segunda leva dos imigrantes japoneses para o Brasil, foi financiada pelos governos das províncias centrais japoneses. As causas são a suspensão das subvenções do governo paulista, em 1922, e o estabelecimento da quota limitando a entrada de imigrantes japoneses nos Estados Unidos, em 1914.

${ }^{42}$ Entende-se por área de atuação legal aquela que consta no Estatuto. Enquanto que a área de atuação efetiva é aquela por onde se distribuem os cooperados. (SEABRA, 1977, pág. 16).
} 
O referido acordo não chegou a cumprido até o ano seguinte quando foi criada a Cooperativa Central Agrícola de São Paulo, que passaria a exercer a função de central das cooperativas paulistas, tendo, inclusive, como uma das afiliadas a C.A. Mista de Mogi das Cruzes.

Com a afiliação à Cooperativa Central Agrícola de São Paulo, a área de atuação da C.A. Mista de Mogi das Cruzes passou a ser redefinida e o acordo firmado em 1933 junto ao Consulado japonês e à C.A. de Cotia deixou de ser respeitado. E em 1944, sua área de atuação abrangia toda a área dos municípios próximos a Mogi das Cruzes e se estendia até os do Vale do Paraíba paulista; em 1949, a área de atuação sofre uma redução, passando a abranger somente a área dos municípios onde se distribuíam os cooperados, a área de atuação efetiva; mas, em 1953, a área de atuação passa a ser expandida atingindo, desta vez, as áreas dos municípios do Vale do Paraíba e Litoral Norte Paulista, da Baixada Santista e dos localizados na região de Campinas.

Esta ampliação era justificada com o intuito de desenvolver planos de instalação de núcleos de colônias agrícolas para pequenos cooperados em atividades horti-fruti-granjeiras do tipo das praticadas pelos seus sócios concentrados nos municípios de Moji das Cruzes e imediatamente vizinhos. A partir de então (1953) nenhuma modificação foi registrada na sua área de ação. (SEABRA, 1977, pág. 21).

Apesar de a área de atuação dessa cooperativa ser relativamente grande, a distribuição espacial de seus cooperados era bastante concentrada. Somente em dois municípios, Mogi das Cruzes e Suzano, se concentravam 81,4\% dos cooperados e, apenas, $18,6 \%$ estavam no Vale do Paraíba, sendo que os dos municípios de Guararema e Jacareí eram os de maior concentração.

Mas, em função de sua ação está restrita às áreas hortifrutigranjeiras periféricas à cidade-sede; à estreita ligação com os produtores granjeiros destas áreas e à ação direta de outras cooperativas, que mesmo com sedes na capital impunham uma grande concorrência, a C. A. Mista de Mogi das Cruzes não conseguiu impedir o avanço das duas maiores cooperativas paulistanas, isto é, da 
C, A. de Cotia e a C.A. Central Sul-Brasil, encerrando assim suas atividades ${ }^{43}$, apesar de sua afiliação à Cooperativa Agrícola Central de São Paulo.

Acreditamos que a análise sobre a estrutura de comercialização, que compreende fundamentalmente os setores mais tradicionais e importantes dentro da administração geral das cooperativas, seja o que melhor possa nos ajudar na compreensão do papel que as cooperativas paulistas desempenharam no abastecimento de alimentos para os centros urbanos, especialmente para a cidade de São Paulo. Para isso, buscaremos compreender como funcionavam os pontos de comercialização e como o seu funcionamento organizava o abastecimento do mercado de hortaliças na cidade de São Paulo.

Não se trata de elaborar todo um perfil que caracterizaria o mercado de hortaliças da cidade de São Paulo que, mesmo antes dos tempos das cooperativas, já era bastante complexo, pois, esse não é o objetivo deste trabalho, mas, o de compreendermos como o conjunto das cooperativas desempenhava sua função de principal fornecedor de alimentos para os grandes centros urbanos, particularmente o paulistano.

Desse modo, analisaremos como as grandes cooperativas, a Cotia e a Sul-Brasil e, eventualmente, uma outra, organizavam as estruturas dos setores de venda e o de compra de mercadorias, a fim de sabermos como eles funcionavam nas cidades onde estavam instalados.

DE LA CORTE (1985) enumera uma série de características que são próprias à cidade de São Paulo, as quais formam suas bases econômicas, geográficas, alimentícias, etc., e que em função delas a cidade passou a influenciar profundamente as atividades econômicas dos centros produtores que estão a sua volta.

São fatores importantes para explicar estas características da cidade de São Paulo, entre outros, a influência dos hábitos alimentares dos imigrantes estrangeiros, a existência de porcentagem elevada para o país de populações das classes média e alta, as maiores consumidoras dos produtos hortifrutigranjeiras. Além de centro de grande concentração de japoneses, italianos, espanhóis, alemães, sírio-libaneses, poloneses e

\footnotetext{
${ }^{43}$ Até o fechamento deste trabalho, não conseguimos descobrir em que data ocorreu o encerramento.
} 
outros, também o é de brasileiros imigrantes de outros Estados que trouxeram novos alimentos para a dieta paulistana ou fizeram manter o consumo de certos produtos tradicionais. (DE LACORTE, 1985, pág. 16).

Mas, os hábitos alimentares, aos quais DE LA CORTE se refere, só puderam ser experimentados após o desenvolvimento das novas culturas e técnicas agrícolas, trazidas pelos imigrantes europeus e asiáticos e pelos brasileiros de outras regiões, que contou com a necessidade de se implantar um complexo sistema de escoamento e distribuição dos alimentos, pelos mercados consumidores.

A cidade de São Paulo, assim com outras grandes metrópoles, converteuse em centro de complexa engrenagem comercial, pois devido às características próprias de seu desenvolvimento urbano, é ao mesmo tempo receptora e redistribuidora de alimentos que se destinam não somente à sua população ou a de seu Estado, mas também a outras áreas urbanas do país, principalmente Rio de Janeiro e Belo Horizonte, mas em se tratando de produtos hortifrutigranjeiros também para Brasília, Curitiba, Porto Alegre e mesmo Salvador, Recife e Belém. (Idem, pág. 11).

As mudanças nos hábitos alimentares, tanto influenciam a organização da produção agrícola, em geral, quanto interferem nos circuitos comerciais. Por um lado, os produtores foram obrigados a mudarem os sistemas agrícolas, produzindo e oferecendo continuadamente novos produtos e, a maneira que encontraram foi o cooperativismo e, por outro, os órgãos de comercialização tiveram que criar novos sistemas de vendas.

\section{1 - O sistema de vendas}

O sistema de vendas utilizado pela Cooperativa de Cotia, que primeiramente se restringiu à venda de batatas, se realizava em depósitos que eram, inicialmente, alugados e que se localizavam em certos pontos comerciais da cidade de São Paulo e se destinavam à venda de batatas. Os primeiros depósitos funcionavam junto ao Mercado de Pinheiros e no bairro de Tucuruvi, ambos na cidade de São Paulo. Havia ainda um posto de vendas que funcionava na praça da cidade do Rio de Janeiro. 
Após dez anos de sua criação, a Cooperativa de Cotia já contava com três depósitos e vários postos de vendas de batatas: além dos mencionados acima, ainda na década de 20 , foi instalado um outro depósito no centro da cidade de São Paulo, junto ao Mercado Municipal na rua Santa Rosa, na zona cerealista da cidade, e vários postos de vendas, todos de batatas, nas cidades de Santos, Rio de Janeiro, Minas Gerais e em cidades das Regiões Nordeste e Norte.

Em 1934, criava-se a Secção de Verduras pela incorporação à Cotia da Cooperativa de Produção de Hortaliças de Cotia, cuja criação se deu pelos próprios agricultores associados da Cotia que haviam passado ao cultivo de hortaliças em substituição à monocultura da batata.

Para SEABRA, esta substituição se deve a iniciativa que cerca de 30 famílias de agricultores tiveram, residentes na zona do Moinho Velho no município de Cotia, em função dos reflexos negativos causados pela Segunda Guerra Mundial sobre a produção da batata, mas, também, para atender aos demais produtores de hortaliças, (cerca de duas mil famílias) que se encontravam espalhados por diversos municípios próximos à cidade de São Paulo onde ainda não atuava uma cooperativa, sendo principalmente produtores de tomates que como os de batatas enfrentavam dificuldades de comercialização nos mercados paulista e carioca. (1977: págs.115 e 116).

Em 1937, três anos após a criação da Secção de Verduras, já funcionava um posto de vendas na cidade de São Paulo e outro na cidade do Rio de Janeiro, para onde era destinada a produção dos agricultores cooperados dos municípios de Mogi das Cruzes e Suzano. E, ainda, neste mesmo, foi criada a Secção de Ovos. Desse modo, formava-se a trilogia: batatas, tomates e ovos, de produtos que durante mais de vinte anos iria dominar o setor de vendas desta cooperativa.

A partir disso, a Cooperativa de Cotia passa a experimentar uma grande expansão de suas atividades, que se iniciou nos anos finais da década de 30 , quando sua área de atuação legal foi estendida para todo Estado de São Paulo.

Esta expansão das atividades era, conforme afirma SEABRA: "resposta à expansão da agricultura voltada ao mercado urbano; ao desenvolvimento das atividades agrícolas dos imigrantes japoneses, bastante vinculados a estes 
mercados; resposta, à sua própria repercussão junto a esta coletividade dos êxitos alcançados pela organização, etc.”. (Idem, pág. 117).

Mas, a expansão que se verificava antes de 1930, passa a partir da década de 30 a provocar a ampliação do número das instalações, depósitos e postos de venda, reforçada pelo surgimento de novos setores e dos tipos de organização das atividades agrícolas que a cooperativa ia criando. Tudo isso, assinala SEABRA, “[...] provocaria um extraordinário aumento dos postos de vendas e, ainda, da complexidade dos mecanismos de vendas e, de resto, do processo de comercialização em geral". (Ibdem, idem).

As cooperativas Central Agrícola de São Paulo e Sul-Brasil, também conheceram seu período de expansão, após a segunda metade da década de 40 , isto é, após o da Cooperativa de Cotia, que já se encontrava em franca expansão.

Com a necessidade de se estender a rede de comercialização interna de atuação direta, em função do aumento do volume produzido por seus cooperados, após a Segunda Guerra Mundial, estas cooperativas passam a instalar postos de vendas em várias cidades do Centro-Sul, mas, sobretudo, nas do interior do estado de São Paulo e Paraná. Para tanto, decidiu-se pela descentralização dos seus postos de venda, partindo-se para a comercialização direta, de porta em porta, realizada por caminhões, próprios ou fretados, como postos de venda aos consumidores, portanto somente a varejo, nos bairros, feiras, mercados regionais ou locais ou mesmo fora deles.

Na zona do Mercado Municipal da cidade de São Paulo, funcionava o depósito urbano que recebia, classificava e vendia a produção de tomates, ovos, verduras e frutas, atendendo ao abastecimento daquela cidade, além do de outras cidades e também da cidade do Rio de Janeiro. Nesta última, funcionava um depósito que recebia os produtos transferidos da sede, do depósito urbano, localizado na cidade de São Paulo, e dos produtores cooperados dos municípios de Mogi das Cruzes, Suzano, do Vale do Paraíba e Baixada Fluminense.

Já na cidade de Santos, funcionava um outro depósito que recebia produtos do depósito urbano de São Paulo além da produção de legumes e 
batatas dos produtores cooperados que se localizavam nos municípios da Baixada Santista e da região de Juquiá.

Havia, ainda, um posto de venda autônoma que funcionava na cidade de Sorocaba.

A partir de década de 50, a expansão se deu por conta do aumento do número de postos de vendas, quando foram inaugurados, pela Central Agrícola de São Paulo, os das cidades de Belo Horizonte, Juiz de Fora, e o de Campos para a venda no atacado e varejo.

Já a Cooperativa de Cotia, num plano de expansão de seus postos de venda direta, passou a instalar postos de vendas nas cidades de Londrina e Carlópolis, no estado do Paraná, e nas de Barretos e Bragança Paulista, no estado de São Paulo. Além disso, instalou boxes de venda a varejo nos mercados de Osasco, Lapa e mais quatro deles no Entreposto Municipal de Gêneros Alimentícios de São Paulo; barracas em cinco feiras livres; um posto de vendas de ovos e aves, junto à sede; as vendas do posto de Santos foram estendidas para as cidades vizinhas de Guarujá e Cubatão e, finalmente, ampliaram-se as vendas na praça da cidade do Rio Janeiro, sendo um ponto no Mercado Municipal; outro na Praça 15 e um terceiro na rua Bonfim.

A partir de 1959 e estendida até 1966, ocorre uma nova fase de expansão das áreas de atuação das cooperativas, com a instalação de novos postos de vendas: a da Cotia, por exemplo, chega a dobrar o número de postos de vendas com a instalação, em 1955, de mais sete postos de vendas na cidade de São Paulo, sendo um em cada bairro: Lapa, Penha, Santo Amaro, Vila Mariana, Mooca e Pinheiros. E na cidade do Rio de Janeiro, instalaram-se várias centrais de distribuição, por caminhão, nos três postos anteriormente mencionados, além da instalação de numerosos postos de vendas em cidades da Região Centro-Sul.

Em São Paulo, o número de postos de venda mais que dobrou ${ }^{44}$ chegando a 40 em 1966, aumentando sobretudo a instalação de unidades varejistas (2 em 1961; 15 em 1966). Ainda neste ano começava a funcionar em São Paulo o Centro Estadual de Abastecimento S.A. (C.E.A.S.A.) para onde a

\footnotetext{
${ }^{44}$ Grifo nosso.
} 
Cooperativa de Cotia transferiu as vendas de hortaliças e legumes, tomates e frutas que operavam no antigo entreposto da cidade, a partir de então paralisado. (SEABRA, 1977, pág. 119).

Com o grande crescimento da rede de comercialização direta dessa cooperativa, a instituição passa a apresentar um caráter cada vez mais nacional. $\mathrm{E}$, isso, não ocorria somente com a Cotia. O mesmo ocorre com outras grandes cooperativas como, por exemplo, na Cooperativa Central Sul-Brasil relatado por SEABRA:

A Sul-Brasil, até o fim dos anos 40 vendia seus produtos através de três secções distintas: batata, tomate e ovos, instaladas na capital paulista, não operando diretamente na praça do Rio de Janeiro. Todas estas secções localizavam-se na zona do Mercado Municipal Central, e trabalhavam também com serviço de distribuição urbana.

No ano de 1952 foi instalado o depósito da cidade do Rio de Janeiro \{...\} Um ano depois passava a atuar dentro do Entreposto Municipal de Gêneros Alimentícios de São Paulo, o \{...\} movimento da secção de verduras da cooperativa no exercício de 1953-54.

Até 1957 seu aparato de comercialização estava, em São Paulo, quase todo situado na zona do Mercado Central, mas a secção de tomates fora desdobrada da de verduras; e a de cereais da de batatas e já funcionavam 2 postos de vendas de ovos. Houvera sido instalado o primeiro posto de vendas no bairro do Tucuruvi e também fora aberto um na cidade de Santos. Além disso, o depósito regional de Curitiba também efetuava vendas diretas.

\{...\} (a partir de 1966) foram abertos postos de vendas em São Judas Tadeu e Santo André, ambos como os outros, com serviço de distribuição, e implantado o serviço de vendas de aves abatidas.

No Rio de Janeiro passavam a funcionar 3 postos de vendas com distribuição: um no Centro de Abastecimento de São Sebastião; um junto ao mercado distrital de Madureira; e outro no chamado Entreposto da Batata.

Nos outros estados, apenas foram iniciadas as vendas diretas pelo depósito de Porto Alegre, somando-se ao de Curitiba que já as realizava antes de 1960. (1977: págs. 119 e 121). 


\section{2 - O sistema de compras}

O Setor de Compras que, praticamente, nascia junto com a cooperativa, tinha a função de organizar as compras de bens de produção e sua distribuição para seus cooperados.

Em face de falta de capitais para a compra destes produtos, as cooperativas passaram a instituir em seus Estatutos a cobrança de um depósito compulsório que correspondia a uma porcentagem, no caso da Cotia a porcentagem, instituída em 1930, era de $5 \%$ sobre o valor das vendas de batata, sobre as vendas efetuadas para formar reserva de capital para aquisição dos bens de produção.

Em princípio, as cooperativas adquiriam e forneciam a seus cooperados insumos à produção. As atividades hortifrutigranjeiras, como base das vendas até a década de 60 , foram as mais beneficiadas apresentando, com isso, uma maior evolução que as demais culturas e atividades desenvolvidas dentro das cooperativas.

As principais atividades desenvolvidas pelo Setor de Compras eram:

a) aquisição de bens de produção - este setor após um certo crescimento, era desdobrado em pequenas secções de compras de (1) sementes, mudas e adubos; (2) máquinas e instrumentos agrícolas; (3) inseticidas e fungicidas e (4) artigos de primeira necessidade;

b) aquisição direta das mercadorias - para desempenhá-la, eram formados grupos de representantes que tinham a tarefa de comprar mercadorias nas praças onde a cooperativa atuava, mas também no exterior, para distribuição aos cooperados;

c) venda e distribuição de bens - eram efetuadas diretamente nos depósitos específicos com essa finalidade, entretanto, só havia pronta-entrega de mercadorias de consumo mais imediato, como a de artigos domésticos, gêneros alimentícios, pequenos utensílios agrícolas, etc., enquanto, as mercadorias, mais volumosas ou de requisição mais esporádica, como as máquinas, eletro- 
doméstico mais sofisticados, adubos, etc., teriam de ser solicitadas, através de pedidos, à sede central; e

d) preparo e produção das mercadorias a serem distribuídas - estas atividades consistiam na preparação de adubos e de rações para aves; na produção de sementes e mudas, geralmente efetuadas com o auxílio dos associados em campos de cooperação; desenvolvimento de campos experimentais e na multiplicação de pintos.

A Cooperativa de Cotia foi a que mais se desenvolveu na preparação de adubos. Havia, em 1967, doze tipos diferentes destinados às culturas de batata, tomate, cebola, cereais, mandioquinha, batata-doce, hortaliças, banana, chá, algodão e café. Já o preparo de rações, também atingiu o maior desenvolvimento entre as cooperativas, no mesmo ano: eram 15 tipos, sendo 4 para poedeiras; 2 para aves de corte; 1 para reprodutores de poedeiras; 3 para reprodutores de corte; 2 concentradas; 2 para suínos; 1 para vacas leiteiras.

As cooperativas Sul-Brasil e a Mista de Mogi das Cruzes, apesar de serem menores que a de Cotia, também fabricavam, em seus moinhos, fubá e quirela de milho, o que no caso da Sul-Brasil representava cerca de $40 \%$ das rações para aves; rações balanceadas e adubos compostos.

\section{3 - A importância das cooperativas para os centros urbanos}

Analisamos até aqui, ainda que de modo restrito, a importância das atividades, venda e compra, das cooperativas numa tentativa de se ter uma idéia básica sobre as operações comerciais que efetuavam na cidade de São Paulo. Falta-nos saber qual foi o papel que as cooperativas desenvolveram no abastecimento para a cidade de São Paulo, como maior centro consumidor e distribuidor de gêneros alimentícios, especialmente os da horticultura. 
Participação percentual das Cooperativas Agrícolas na Distribuição de Alguns Gêneros alimentícios na Capital de São Paulo - Final da década de 50.

\begin{tabular}{|l|c|c|}
\hline \multicolumn{1}{|c|}{ PRODUTOS } & $\begin{array}{c}\text { COOPERATIVAS } \\
(\mathbf{\%})\end{array}$ & $\begin{array}{c}\text { PARTICULARES } \\
\mathbf{( \% )}\end{array}$ \\
\hline Tomate & 80 & 20 \\
\hline Alface & 86 & 14 \\
\hline Couve-Flor & 79 & 21 \\
\hline Repolho & 66 & 34 \\
\hline Cenoura & 83 & 17 \\
\hline Pimentão & 82 & 18 \\
\hline Pepino & 86 & 14 \\
\hline Caqui & 75 & 25 \\
\hline Pêssego & 63 & 37 \\
\hline Batata & 67 & 33 \\
\hline Ovos de granja & 60 & 40 \\
\hline
\end{tabular}

Fonte: Anuário Brasileiro Cooperativista (1961:3) apud SEABRA (1977:251).

Apesar das informações contidas na tabela acima, representarem apenas estimativas anuais para a década de 1950, como assinala SEABRA, temos que considerar que no cômputo geral destas culturas, que são comumente as principais que compõem as atividades hortifrutigranjeiras, havia uma inquestionável e maciça participação da produção das cooperativas no abastecimento da cidade, o que nos permite dizer que este quadro tenha se prolongado, pelo menos durante as décadas de 60 e 70, quando houve a expansão destas atividades por ocasião da implantação de medidas de "modernização" da agricultura, pelos governos militares. Entre as quais a aplicação do Estatuto da Terra, em 1964; a criação do Serviço Rural da Capital, em 1965; a criação do CEASA, em 1966, mas, além disso, também quando se deu o crescimento numérico dos depósitos e postos de vendas das cooperativas, na cidade de São Paulo, especialmente, em decorrência do aumento do mercado consumidor nacional, mas, sobretudo, paulista, gerado pela urbanização concomitante com os processos de industrialização, a partir dos anos finais da década de 50, e da "modernização" iniciada com o regime militar em 1964.

Desse modo, a elevada participação da produção agrícola das cooperativas no abastecimento de produtos alimentícios, sobretudo, os da horticultura, para os grandes centros urbanos, comprovam sua importância.

Assim, fica bastante acentuado o importante papel na economia nacional que as cooperativas desempenharam, tanto no abastecimento de gêneros 
alimentícios para as populações dos grandes centros urbanos, quanto na aquisição de bens para seus cooperados, através da atuação de suas atividades nos diferentes mercados de várias cidades brasileiras, e, mais especialmente nos da cidade de São Paulo até as décadas de 1970/80, quando iniciou-se o encerramento de suas atividades.

Se, por um lado, as cooperativas, ao desempenharem a função de fornecedoras de alimentos aos centros urbanos, dependiam, deste modo, da formação do mercado consumidor, por outro, também, contribuíram para sua formação quando adquiriam bens de produção e de consumo para os seus cooperados.

\section{4 - O fim das cooperativas: as causas prováveis}

Apesar de tudo isso que expusemos as cooperativas paulistas não conseguiram manter suas estruturas em funcionamento, encerrando, por fim, suas atividades ainda nos anos noventa do século passado. As causas do fechamento ainda são o motivo de muitos desencontros de opinião.

Mas, a partir de algumas entrevistas com pessoas que tiveram ligação com as duas maiores cooperativas, a C.A. Sul-Brasil e a C.A. de Cotia, em Mogi das Cruzes, é possível listar algumas causas que, de certo modo, foram comuns nas análises realizadas pelos entrevistados e também por SEABRA.

Segundo informações que obtivemos junto ao escritório da Cooperativa Agrícola Sul-Brasil, em 1998, quando ainda funcionava o escritório em Mogi das Cruzes, foram os elevados impostos que recaíam sobre as cooperativas que provocaram seu fechamento. Em entrevista realizada em outubro de 2005, o atual Secretário de Agronegócio da Prefeitura de Mogi das Cruzes, o senhor $\mathrm{TAKASHI}^{45}$, informou que o principal motivo teria sido o fato de que muitos cooperados nem sempre entregavam toda a produção à cooperativa, preferindo, às vezes, comercializar sua produção diretamente quando os preços eram mais favoráveis.

\footnotetext{
${ }^{45}$ O senhor TAKASHI é o atual Secretário de Agronegócios da Prefeitura Municipal de Mogi das Cruzes. É ex-chacareiro e chegou a ser cooperado da C.A. de Cotia.
} 
Ainda, em outra entrevista, o Diretor-chefe do CATI de Mogi das Cruzes, o senhor ROBERTO (a forma correta de citar este e os demais entrevistados é apresentando o nome completo, grafando de forma normal e dando o cargo já no corpo do texto), ${ }^{46}$ em maio de 2005 , lembrou as dificuldades que as cooperativas tinham para administrar todas as áreas de atuação, em virtude da grande extensão a que chegaram as maiores. "Chegou a um certo ponto que a administração fugia ao controle dos administradores", disse, sendo esse fato a principal causa do fechamento das cooperativas.

Em outra entrevista que realizamos com o senhor SÉRGIO ${ }^{47}$, em 03 de julho de 2004, ele nos informou que a principal causa do fechamento da C. A. de Cotia, na qual o seu pai havia trabalhado por muitos anos e ele um pouco menos, teria sido os investimentos em outros setores econômicos que a cooperativa passou a fazer sem, contudo, considerar os riscos.

Numa outra entrevista, que nos foi concedida pelo senhor RAFAEL HIRATA $^{48}$, em maio de 2003, fomos informados de que as causas do fechamento das cooperativas mogianas Itapeti, Progresso, Agromogi e Tietê as causas do fechamento delas teriam sido a má-gerência e o desvio de capitais pelos seus administradores.

A nossa primeira entrevista, a respeito do fechamento das cooperativas em Mogi das Cruzes, foi realizada com o senhor DURVAL, em 1998, quando era Diretor de Abastecimento Municipal de Mogi das Cruzes. Na ocasião ele nos informou que $100 \%$ dos agricultores eram associados a alguma cooperativa, mas nem todos comercializavam todos os produtos diretamente pela cooperativa.

Sobre, por exemplo, o fechamento da C. A. Mista de Suzano em 1969, após vinte anos de existência, a direção se justificou da seguinte forma:

Deficiência de transações, não só quanto à comercialização de produtos, tanto a venda de mercadorias agroavícolas, bem como de mercadorias de

\footnotetext{
${ }^{46} \mathrm{O}$ senhor ROBERTO é Engenheiro Agrônomo e atual chefe do Centro de Assistência Técnica e Integral.

47 O senhor SÉRGIO KOJI MIYANO é atualmente o Presidente da Associação dos Produtores e Distribuidores de Produtos Hortifrutigranjeiros do Estado de São Paulo, entidade que congrega cerca de 75 agricultores, cuja sede se encontra atualmente situada dentro da Central de Abastecimento de AgroProdutores que se localiza nos galpões da antiga estação de trem do Pari, na zona cerealista na capital.

${ }^{48} \mathrm{O}$ senhor RAFAEL HIRATA era um ex-funcionário do Banco do Brasil e trabalhou junto à gerência da Carteira de Crédito Agrícola, em Mogi das Cruzes, de 1956 a 1975.
} 
consumo pessoal, cujo resultado não chega para cobrir nem a metade das despesas, acumulando-se de dia para dia o prejuízo" ... sic ... "Não é somente a nossa cooperativa que luta com sérias dificuldades, mas todos que equiparados ao comércio comum, no que diz respeito à incidência do I.C.M e outros impostos, não resistem à concorrência deste, visto que suas transações se limitam às pessoas inscritas em seu quadro social, que nem todos transacionam com a Cooperativa, e os poucos que o fazem, limitam estas transações ao mínimo, visto que as Cooperativas, já agora não podem oferecer-Ihes vantagens de caráter pecuniário, uma vez que os seus preços, por força do acima alegado, são superiores ao do comércio comum. Além disso estão sujeitas a uma fiscalização rigorosa que por qualquer infração da Lei Fiscal e regulamentos, embora sem prejuízo do Fisco, aplicam multas astronômicas, o que muito preocupa a diretoria, que tudo faz para trabalhar com honestidade, tanto é que a própria organização de nossos serviços em cuja contabilidade são registrados todos os fatos e atos sociais dão azo a que os fiscais tenham elementos para aplicação de multas que se tiverem de ser pagas absorverão todo o ativo da sociedade. (Pasta de documentos jurídicos da referida cooperativa no DAC citado por SEABRA, 1977, pág. 75).

Com relação às grandes cooperativas, a Cotia e a Sul-Brasil, elas estenderam suas áreas de atuação para outros estados, perdendo desse modo o controle de toda a administração local e regional. Houve casos em que a administração era corrupta ou simplesmente incapacitada para gerenciar certas áreas de atuação. Há uma outra causa que aparece mais comumente nas falas dos entrevistados, a de que teriam sido investimentos mal-sucedidos em outras áreas distintas da agrícola, como a imobiliária e a de aplicação financeira, as causas principais do fechamento destas cooperativas.

Desse modo, tudo indica que teria sido uma série de fatores que concorreram para o fechamento das cooperativas agrícola que atuavam em Mogi das Cruzes: a competitividade entre as cooperativas locais e destas para com as regionais e mesmo nacionais; a concorrência por mercados consumidores obrigando a ampliação das áreas de atuação; a ausência de capacidade administrativa; suspensão das vantagens fiscais de que gozavam as cooperativas: 
a cobrança do Imposto sobre Circulação de Mercadorias e a elevação da alíquota; desvio de recursos; descontrole administrativo e grandes investimentos em outros setores econômicos.

Todos estes fatores despertaram nos agricultores uma grande resistência quanto a uma possível retomada desse tipo de organização na região de Mogi das Cruzes. $^{49}$ Desde os últimos anos da década de 90, quando as maiores cooperativas encerraram suas atividades em Mogi das Cruzes, a C. A. de Cotia ${ }^{50}$, um pouco mais cedo, e a C. Central Sul-Brasil, não há mais cooperativas agrícolas no município.

\section{3 - A organização atual do mercado}

Já vimos anteriormente, que durante o século XIX, a produção agrícola dos municípios periféricos à cidade de São Paulo, a partir do que vimos sobre Mogi das Cruzes, foi sendo desenvolvida para atender aos seus interesses, os quais passavam pelo estabelecimento de uma organização de suas estruturas internas de abastecimento. $E$ isso ficaria mais patente, ainda, quando se refere aos tempos das cooperativas, que apresentavam um extraordinário crescimento quando instalavam seus depósitos ou postos de vendas dentro ou nas imediações dos mercados públicos e centros de abastecimentos estatais.

Entretanto, se por um lado, o crescimento do número dos pontos de distribuição e de venda, verificado durante a década de 50 , permitiu que as cooperativas estivessem presentes em diversos bairros paulistanos comandando a comercialização dos produtos hortifrutigranjeiros na capital paulista, por outro, o fechamento deles passou a promover uma certa desorganização dos pontos de mercados em que atuavam, durante a década de 80.

Vimos também, que a chegada de milhares de colonos europeus e asiáticos e de brasileiros de outras regiões, que introduziram novas culturas e técnicas na agricultura paulista, e a implantação de estruturas de racionalização

\footnotetext{
${ }^{49}$ É interessante saber que é, justamente, entre os agricultores de ascendência japonesa que se verifica a maior resistência ao cooperativismo.

50 Atualmente, essa Cooperativa encontra-se em processo de liquidação judicial, conforme informações fornecidas pelo senhor MOTO, funcionário da empresa que está efetuando o processo de liquidação, por telefone, em 17/01/2006.
} 
de abastecimento de produtos alimentícios, durante a fase de constituição da metrópole paulista, modificaram os hábitos alimentares da população ${ }^{51}$ o que exigiu dos produtores a mudança de seus sistemas agrícolas.

Vimos, ainda, que as transformações provocadas pelos grandes centros urbanos interferem tanto nas demandas quanto na reorganização dos circuitos comerciais de abastecimentos de produtos, o que, num primeiro momento, se deu por meio da ação direta do Estado na organização dos sistemas de vendas no atacado e varejo.

Desse modo, as transformações por que passam as metrópoles provocam a reorganização nos circuitos comerciais. Tais circuitos, ao serem reorganizados, exigem, por sua vez, que os sistemas de produção, praticados nas áreas onde as mercadorias são produzidas, se ajustem ao novo formato organizativo empregado no sistema.

É difícil precisar, com exatidão, se teria sido esse o processo pelo qual o sistema de abastecimento alimentício da cidade de São Paulo passou ainda nos primórdios de sua história. Mas, o que se pode dizer é que desde o século XVIII, a produção dos municípios circunvizinhos àquela cidade, já se encontrava dependente de seus mercados. Um exemplo disso é o próprio município de Mogi das Cruzes, como fora observado por ZALUAR em 1860/61.

Ainda antes das cooperativas, o abastecimento de produtos alimentícios para a cidade de São Paulo se realizava sem que o sistema fosse normatizado pelo poder público, embora contasse com um sistema desenvolvido autonomamente pelos próprios produtores, comerciantes e consumidores de cada localidade onde se realizava.

Com as cooperativas, ou seja, com a expansão dos inúmeros postos de vendas espalhados pelos bairros paulistanos, o sistema foi (re) organizado de acordo com a demanda que se verificava em cada local de venda e com as possibilidades de investimento que cada cooperativa dispunha. Desse modo,

\footnotetext{
FARINA et all (s.d), considera que, em 1996, o padrão brasileiro de consumo de FLF (frutas e legumes frescos) era muito desigual. Com base em dados do Instituto Nacional de Alimentação e Nutrição afirma que apenas $44 \%$ da população consumiam frutas e $58 \%$ legumes, sendo que quase $70 \%$ da demanda total estavam concentrados nas cidades de São Paulo, Rio de Janeiro e Belo Horizonte.
} 
inverteu-se a lógica, isto é, a oferta de produtos no mercado que, no século XIX, era realizada de acordo com a capacidade de trabalho e necessidades de consumo dos agricultores, passou a ser no século $\mathrm{XX}$, de acordo com as demandas do mercado.

Esse processo, que contou com a implantação de medidas "modernas" na agricultura, passou a normatizar o sistema de abastecimento de produtos alimentícios para os centros urbanos, quando promoveu à subordinação da produção de muitas pequenas unidades ao mercado e a transformação de muitos agricultores em meros produtores de mercadorias.

Mas, com o processo de encerramento das atividades das grandes cooperativas, ocorrido durante as décadas de 70 e 80 , parte dos mercados dos grandes centros urbanos, onde elas eram responsáveis pelo fornecimento dos maiores volumes, passa a se ressentir e uma nova (re) organização do sistema de abastecimento começa a se configurar em São Paulo, especialmente, com o fortalecimento das centrais de abastecimento e com o crescimento das grandes redes privadas de supermercados a partir do início dos anos 80 .

Para compreendermos este período, que se sucedeu após o fechamento das cooperativas, faremos um breve resgate dos principais aspectos históricos sobre a origem das centrais de abastecimento, tomando como referencial os períodos em que os problemas de abastecimento foram mais agudos.

\section{1 - Os aspectos históricos}

BELIK $^{52}$ (2000), afirma que, no Brasil, as chamadas crises de abastecimento sempre tiveram um papel muito importante na determinação das políticas de abastecimento. Lembra, ainda, que no país, diante do explosivo crescimento urbano e de uma crônica inflação, as possibilidades de discussão de um planejamento do sistema de abastecimento alimentar sempre foram atropeladas pelo imediatismo e medidas autoritárias.

\footnotetext{
${ }^{52}$ Professor do Instituto de Economia da UNICAMP.
} 
Em função disso, percebe-se que, conforme a história, os marcos da política de abastecimento sempre foram definidos após as crises. Vejamos, segundo BELIK, alguns destes períodos:

O primeiro período de crise de abastecimento, ocorre como reação tardia à Grande Depressão Mundial, em 1870. Os problemas de abastecimento eram, naquela época, basicamente de produção. A resposta do governo foi dada a partir de duas medidas: (I) exportar produtos tropicais e (II) implantar núcleos de colonização voltados para a produção de alimentos. (BELIK: 2000, pág. 132);

O segundo, ocorre devido à elevação do custo de vida, em 1917, quando os investimentos foram todos canalizados para sustentar a produção do café. Após uma sucessão de problemas sociais, como greves e manifestações dos trabalhadores urbanos, impulsionados pela organização sindical trazida pelos imigrantes e pela vitória da Revolução Russa, além de saques aos estabelecimentos comerciais da cidade de São Paulo, o Estado cria em 1918, o Comissariado de Alimentação Pública que tinha por objetivo a regulação dos preços e estoques dos produtos de primeira necessidade através da confecção de tabelas quinzenais com preços tabelados. (Idem, pág. 133);

O terceiro, ocorre em decorrência da crise mundial provocada pela "quebra" da Bolsa de Valores de Nova, em 1929. A medida adotada pelo governo de Washington Luís foi o congelamento de preços e a prisão para os comerciantes que não respeitassem as tabelas.

Entretanto, pequenos, mas contínuos ciclos de crise persistiram até a década de 30 , em função do rápido crescimento da população urbana e de maiores dificuldades para importação. Para contornar as crises de pão, leite, carnes e outros produtos, a ditadura getulista monta uma estrutura supraministerial com o objetivo de controlar e punir os responsáveis pelos problemas de abastecimento. Com isso, a administração do abastecimento passou a abranger os incentivos à produção, o controle de preços e a implementação de restaurantes populares. (Ibidem, pág. 133);

$E$, finalmente, o quarto período de crise ocorre em decorrência da elevação dos preços e pela escassez de produtos alimentícios provocadas pela 
desvalorização da moeda brasileira, em função do Acordo de Bretton Wodds, realizado durante a Segunda Guerra Mundial, em 1944, que havia fixado uma nova paridade para o cruzeiro. Com a desvalorização diminuiu-se a importação de produtos da cesta básica, necessários à população mais humilde, tornando os seus preços praticamente proibitivos para esta parcela da população.

Somando-se isso a elevação dos preços, decorrentes da instabilidade das políticas macroeconômicas do governo JK, uma nova crise eclode. O governo, pressionado pelos movimentos sociais e pelo crescente êxodo de famílias camponesas para os centros urbanos, passa a dar ênfase em seu discurso quanto à implantação de uma reforma agrária que era vista como a resolução dos problemas de carestia. (Ibidem, pág. 134/5).

Entretanto, os problemas de abastecimento prosseguiram e encontraram, no governo de João Goulart, a promulgação das Leis Delegadas Nacionais do Abastecimento. Estas Leis permitiram à SUNAB - Superintendência Nacional de Abastecimento - até mesmo fechar os estabelecimentos que desobedecessem às suas determinações, o que tornava o problema de abastecimento um caso de polícia.

Após 1964, com o regime militar, os governos que se sucederam passam a dar um novo tratamento aos problemas relacionados ao abastecimento. Com a adoção de medidas, menos normativas e, mais diretas na organização e na regulação, são instituídos diversos mecanismos de controle do sistema; em 1968, foi criado o GEMAB - Grupo Executivo de Modernização do Abastecimento - que tinha a finalidade de criar um sistema de intervenção direta no comércio de alimentos. Dentre as principais propostas do GEMAB estava a implantação de centrais de abastecimentos nas capitais e centros urbanos sob o controle do SINAC ${ }^{53}$ - Sistema Nacional e Centrais de Abastecimento - que, por sua vez, seria coordenado pela COBAL - Companhia Brasileira de Alimentação.

\footnotetext{
${ }^{53}$ BELIK destaca que faziam parte dos objetivos do SINAC as seguintes metas: redução dos custos diretos e indiretos de comercialização; melhoria nas condições de abastecimento; melhoria da qualidade das informações sobre o mercado; melhor especialização dos comerciantes; eliminação de intermediários desnecessários; melhoria nas condições higiênico-sanitárias e reduções das flutuações e especulações com preços.
} 
As propostas do GEMAB, segundo BELIK, "terminaram por se concretizar no I PND - Plano Nacional de Desenvolvimento do Governo Médici. A implantação da rede de centrais de abastecimento do SINAC se deu preponderantemente no período 1972-1979 com a construção de dezenas de CEASAs, - Centrais de Abastecimento. As últimas CEASAs foram implantadas no início dos anos 80 totalizando 47 instalações, sendo que 13 pertenciam à rede estadual do CEAGESP - Cia. de Entrepostos e Armazéns Gerais do Estado de S. Paulo, que foi o pioneiro na introdução do programa de centrais de abastecimento". (Idem, pág. 136).

Durante o desenvolvimento desta parte do nosso trabalho tivemos a oportunidade de apontar alguns processos como, por exemplo, a expansão do número de postos de vendas das cooperativas, nos bairros, mercados locais e regionais, etc., que certamente provocaram uma maior competitividade entre os postos de vendas, comerciantes e feirantes, sendo estes últimos os mais prejudicados por constituírem-se no principal equipamento de comercialização nos bairros paulistanos até então.

De fato, segundo BELIK, “\{...\} em 1979, o CEAGESP decidiu implementar em território paulista os "varejões" de hortifrutigranjeiros. O diagnóstico era de que o alto preço dos alimentos era decorrente da inadequabilidade das feiras (principal equipamento de comercialização). Segundo estudos desenvolvidos pelos técnicos governamentais do período, os feirantes comercializavam os seus produtos em uma escala muito pequena e portanto tinham a necessidade de aplicar margens altíssimas. A solução era aumentar a escala com um volume comercializado maior. $O$ sucesso do primeiro varejão nas dependências do CEAGESP na cidade de São Paulo levou à criação de outros 24, sendo 16 no interior do estado". (Ibidem, pág. 136).

Uma outra experiência, ainda segundo BELIK, foi a implantação da Rede SOMAR, que era uma rede de supermercados vinculados à COBAL cujo principal atrativo eram os preços extremamente competitivos dos produtos básicos que comercializava. Foram implantadas 100 lojas na década de 80 , mas elas não 
resistiram às pressões das grandes redes privadas que também se expandiram na época.

Desse modo, então, podemos dizer que o período compreendido entre o início do fechamento das grandes cooperativas (1970/80) e o fortalecimento das centrais de abastecimento e o crescimento das grandes redes privadas nacionais de comercialização (1980/90) foi marcado profundamente por uma (re) organização no sistema de distribuição e comercialização na cidade de São Paulo. Junta-se a ele, o período mais recente (1990/2000), quando houve a aquisição de grandes redes privadas nacionais por empresas internacionais que passaram a se instalar e comandar o mercado nacional e, particularmente, o paulista.

\section{2 - A atuação das centrais de abastecimento}

No Brasil, a maior parte da comercialização da produção de hortaliças é distribuída por meio das Centrais de Abastecimento (CEAGESP), sendo o Entreposto da cidade de São Paulo o que recebe os maiores volumes.

HÉLIO JUNQUEIRA e ALVES LUENGO (1999), estimam que 60\% da quantidade de hortaliças consumidas no Brasil sejam comercializados nas Centrais de Abastecimentos da cidade de São Paulo.

Nestas Centrais, geralmente, o agricultor vende sua produção a um atacadista, que por sua vez comercializa com supermercados, quitandas e sacolões. Entretanto, o atacadista obtém seu lucro pela diferença obtida entre o valor do preço pago, aos produtores, pela aquisição das mercadorias, e o valor do preço que recebe pela venda das mercadorias aos seus clientes. Assim, quanto maior for esta diferença, maior será o seu lucro.

É por isso que a forma da comercialização direta, entre o produtor e o consumidor, vem sendo cada vez mais a preferida por estes agentes, seja nas feiras ou pela venda direta dos produtos aos supermercados e restaurantes.

Mas, a comercialização numa central de abastecimento tem suas vantagens: para o consumidor, ela está no fato de que ali estão reunidos num só local todos os produtos, com diferentes qualidades e preços e, para os atacadistas 
e produtores, a vantagem é que num só local há um grande número de consumidores.

É, certamente, a esta particularidade apontada acima e ao fato de comercializarem grandes volumes diários, envolvendo produtores de diferentes regiões e segmentos da economia, que as Centrais de Abastecimento passaram a servir como um "feitor de preços". 54

Para compreendermos o sistema de distribuição de hortaliças existente, atualmente, na cidade de São Paulo concentramos nossas pesquisas sobre as duas maiores centrais, a CEAGESP e a CEAAP, ambas situadas na capital. Realizamos, também, como complemento, uma breve pesquisa sobre cinco distribuidoras de hortaliças, que estão situadas na zona rural do município de Biritiba Mirim.

\subsection{1 - A CEAGESP}

A CEAGESP - Companhia de Entrepostos e Armazéns Gerais do Estado de São Paulo -, foi fundado em maio de 1969, a partir da fusão de duas empresas estatais paulistas: a CEASA e a CEGESP. Em 1997 foi federalizado e vinculado ao Ministério de Agricultura, Pecuária e Abastecimento.

No Estado de São Paulo, a CEAGESP possui 12 Entrepostos, sendo um na capital, onde funciona o maior deles e a Administração Central, e 11 no interior nas cidades de Araraquara, Avaré, Botucatu, Bauru, Tatuí, Fernandópolis, Palmital, Pederneiras, Presidente Prudente, Ribeirão Preto, Santos e São José do Rio Preto.

A CEAGESP é formada por uma ampla estrutura física (lojas, armazéns, silos, frigoríficos, etc.) e por uma estrutura administrativa que coordena o abastecimento de produtos perecíveis, como as hortaliças. As suas unidades de atacado são denominadas de Entrepostos que se constituem em grandes depósitos de mercadorias ou em grandes armazéns onde são guardadas ou vendidas mercadorias de algum Estado ou de empresas privadas. "As unidades

\footnotetext{
54 Esta expressão foi usada por HÉLIO JUNQUEIRA, A. e ALVES LUENGO, R.F. Distribuição de Hortaliças no Brasil. Circular Técnica da EMBRAPA, publicado em setembro de 1999.
} 
da capital e do interior funcionam como um ponto de encontro de produtores e comerciantes. Funcionam como canais de distribuição da produção regional para feiras livres, supermercados, quitandas, sacolões, restaurantes e distribuidoras de hortícolas". 55

O Entreposto da capital, que é o maior de todo sistema CEAGESP, recebe uma grande variedade e quantidade de produtos de cerca de 1.500 municípios brasileiros e de 14 países. Após a comercialização, os produtos são destinados ao abastecimento da população do Estado de São Paulo e de outros Estados brasileiros e de vários países da América Latina. ${ }^{56}$

A comercialização na CEAGESP ocorre tanto no atacado quanto no varejo: A comercialização no atacado $^{57}$ dos legumes, verduras, frutas e flores ocorre durante toda a semana, mas em dia e horários estabelecidos, conforme descritos na tabela abaixo:

Horário de Comercialização de Verduras, Legumes, Frutas e Flores no Entreposto da cidade de São Paulo-2005.

\begin{tabular}{|c|c|c|}
\hline PRODUTO & $\begin{array}{l}\text { DIA DA } \\
\text { SEMANA }\end{array}$ & HORÁRIO \\
\hline Verduras & $\begin{array}{l}2^{\mathrm{a}}, 4^{\mathrm{a}} \text { e } 5^{\mathrm{a}} \text { feira. } \\
3^{\mathrm{a}} \text { e } 6^{\mathrm{a}} \text { feira. } \\
\text { Sábado. }\end{array}$ & $\begin{array}{l}\text { Das } 8 \text { às } 18 \mathrm{hrs} \\
\text { Das } 12: 30 \text { às } 18 \mathrm{~h} \\
\text { Das } 14 \text { às } 17 \mathrm{~h}\end{array}$ \\
\hline Legumes & $2^{\mathrm{a}}$ a Sábado. & Das 8 às $17 \mathrm{~h}$ \\
\hline Frutas & $2^{\mathrm{a}}$ a sábado feira & Das 8 às $17 \mathrm{~h}$ \\
\hline Flores & $2^{\mathrm{a}}$ e $5^{\mathrm{a}}$ feira & Das 5 às $13 \mathrm{~h}$ \\
\hline
\end{tabular}

Fonte: site: www.ceagesp.com.br (13/01/2006)

A fim de manter informados os diversos agentes econômicos e produtores envolvidos com a comercialização pela CEAGESP, a Seção de Economia e Desenvolvimento, coloca diariamente a cotação dos preços dos produtos comercializados, por variedade, segmento e produto, à disposição dos usuários da Internet através do seu sítio eletrônico.

\footnotetext{
${ }^{55}$ Cf. o site: http://www.ceagesp.com.br/ de 13/01/2006.

${ }^{56}$ Idem.

57 O CEAGESP, segundo o seu sítio eletrônico, registrou a comercialização de 2,913 mil toneladas de hortaliças, flores e pescados no ano de 2005 , obtendo um aumento de $4,21 \%$ sobre o ano passado.
} 
A comercialização dos produtos hortifrutigranjeiros, no varejo, ocorre através dos Varejões que são realizados dentro das instalações do Entreposto, sendo 3 na capital e um no Entreposto de Sorocaba.

Os Varejões consistem na venda direta aos consumidores de produtos hortifrutigranjeiros. O primeiro teve início em 1979 e, atualmente, são realizados três no Entreposto de São Paulo, que movimenta cerca de 250 toneladas por mês e ocorrem durante as quartas-feiras, sábados e domingos, e um em Sorocaba, que se realiza aos sábados.

Em 1983, a CEAGESP criou os sacolões, destinados à venda de legumes e verduras a um preço único. E em 1984, criou os Comboios, que funcionavam como mini-Varejões ambulantes.

ZYLBERSTAJN et all (1997), considera que a função de coordenação, que estes Entrepostos desempenham, decorre da centralidade física das trocas nos diferentes Entrepostos regionais, em especial o Entreposto da cidade de São Paulo, que concentra as funções físicas e econômicas no mesmo local.

As hortaliças comercializadas na CEAGESP são provenientes de milhares de pequenas unidades que se concentram nos municípios que tradicionalmente são produtores de produtos hortifrutigranjeiros, denominados popularmente de cinturão verde, sendo a maior parte das entradas procedentes de Ibiúna, Piedade, Campinas, Sorocaba, Suzano, Biritiba Mirim e Mogi das Cruzes.

Os produtos são transportados, geralmente por diferentes tamanhos de caminhões, até o entreposto, onde são negociados e vendidos. São, então, reagrupados e vendidos, novamente, para outros distribuidores atacadistas e/ou varejistas, incluindo aí supermercados, feirantes, quitadas, etc. Oferta e demanda encontram-se, fisicamente, no entreposto, criando-se o serviço de informação, espontaneamente". ${ }^{58}$ (ZYLBERSTAJN, 1997, pág. 377).

Apesar de uma parte ${ }^{59}$ da produção agrícola do município de Mogi das Cruzes ser destinado à CEAGESP, ele não recebe a produção de hortaliças do bairro rural Chácaras de Santo Ângelo, porque os agricultores preferem utilizar o

\footnotetext{
${ }^{58}$ Grifo do autor.

${ }^{59}$ Parte esta que, segundo o Sindicato Rural dos Produtores, totalizava apenas $10 \%$ em 1997. O restante, seguia outro sistema de distribuição.
} 
mercado da Central de Abastecimento de Agroprodutores, que está localizado na zona cerealista da cidade, por vários fatores, os quais serão analisados no próximo item.

A tabela abaixo mostra a porcentagem que corresponde a cada segmento consumidor dos produtos hortifrutigranjeiros comercializados no Entreposto da CEAGESP da capital paulista, nos períodos de 1983 e 1993.

\section{Destino dos Hortifrutigranjeiros comercializados na CEAGESP em São Paulo em 1983 e 1993}

\begin{tabular}{|l|r|r|}
\hline Equipamento Varejista & $\mathbf{1 9 8 3} \mathbf{( \% )}$ & $\mathbf{1 9 9 3} \mathbf{( \% )}$ \\
\hline Feira Livre & $\mathbf{4 8 , 4}$ & $\mathbf{2 8 , 8}$ \\
\hline Supermercado & 12,1 & 16,7 \\
\hline Mercado & 11,0 & 3,3 \\
\hline Ambulante & 7,1 & 3,3 \\
\hline Quitanda & 3,4 & 2,6 \\
\hline Distribuidora & 3,3 & 7,1 \\
\hline Varejão & 0,8 & 2,5 \\
\hline Outra Ceasa & 2,9 & 18,7 \\
\hline Sacolão & - & 12,8 \\
\hline Outro & 11,1 & 4,2 \\
\hline
\end{tabular}

Fonte: SAA - Coordenadoria de Abastecimento, SP. (Cf. BELIK: 2000, pág. 150)

Para BELIK, no início dos anos 80 , os mercados atacadistas, conjuntamente, controlavam a maior parte da comercialização da produção de hortifrutigranjeiros, sendo a feira livre a principal modalidade do comércio varejista desta produção, com 48,4\%; seguida pelos supermercados, com $12,1 \%$ e os Mercados com 11,0\%. Dez anos depois, isto é, em 1993, o quadro mostra que algumas posições foram alteradas: a feira livre diminuiu seu percentual em quase metade, passando para 28,8\%; seguido por outra Ceasa (Entreposto de outra cidade), com 18,7\%; supermercados, agora com o percentual de $16,7 \%$ e o Sacolão com $12,8 \%$.

Durante este período, as maiores perdas de importância ficaram por conta da feira livre, armazéns (Mercado) e quitandas, enquanto que os maiores ganhos ficaram por conta das CEASAs, Sacolões e Distribuidoras.

Com relação à perda de importância por parte das modalidades de feira livre, armazéns e quitandas no abastecimento, BELIK entende que o papel desempenhado pelo atacadista tradicional estabelecido nas CEASAs também 
perde importância, uma vez que, cada vez mais a Grande Distribuidora (super e hipermercados) se utiliza do sistema de compras baseado em centrais de compra e de distribuição.

De fato, isto foi verificado por nós durante nossas pesquisas junto às redes de comercialização do Extra, Carrefour, e Makro. O sistema desenvolvido por elas será apresentado, a seguir, na parte que dedicamos aos supermercados.

BELIK, ainda, constata que a movimentação anual de hortifrutigranjeiros na CEAGESP tenha estagnado entre 1985 a 1997: "Há mais de 12 anos o volume comercializado no maior entreposto atacadista de alimentos da América Latina se encontra estacionado em algo em torno de 2,4 milhões de toneladas". (Idem, pág. 150).

Desse modo, percebe que as grandes redes vêm progressivamente aumentando suas compras por outro sistema que não é o sistema das Centrais de Abastecimento. Como estas redes detêm, atualmente, cerca da metade ${ }^{60}$ do volume comercializado de hortifrutigranjeiros, estima-se, portanto, que gradativamente as Centrais de Abastecimento vão perdendo importância como principais sistemas de abastecimento de hortifrutigranjeiros.

Outros problemas que, particularmente este Entreposto vem enfrentando estão relacionados à sua localização, sendo um deles, provocado por inundações de águas pluviais que ocorrem esporadicamente durante os meses de verão e, outro, pelos grandes congestionamentos que se formam diariamente na região, dificultando o trânsito de pessoas e mercadorias e, outro ainda, à incipiente padronização e normatização das embalagens dos produtos e às questões de aspecto logístico.

HÉLIO JUNQUEIRA e ALVES LUENGO (1999), concordam que não se pode pensar em abastecimento de hortaliças, sem que se considere a pouca qualidade das embalagens utilizadas hoje na CEAGESP. Isto porque, a utilização de embalagens inadequadas, agravadas pelas condições de transporte às quais

\footnotetext{
${ }^{60}$ Comparando dados, de 1970 com os do final da década de 90 , sobre os mercados de lojas tradicionais e os de auto-serviço, BELIK chega à conclusão que atualmente, as de auto-serviço detêm, aproximadamente, $85 \%$ das vendas do varejo, sendo que no caso dos produtos hortifrutigranjeiros, aproximadamente metade das vendas é realizada pela via dos supermercados.
} 
os produtos são submetidos, salienta a necessidade de investimento tecnológico na área de embalagens visando a minimizar as perdas pós-colheita e melhorar a distribuição de hortaliças no Brasil.

ZYLBERSTAJN et all (1997), ao analisar a proposta de privatização do CEAGESP que se encontrava em discussão nos anos 90, considera que, em face do abastecimento de alimentos para uma grande metrópole, como é a cidade de São Paulo, a privatização acompanhada da desmobilização dos ativos, representados pela área atualmente ocupada na cidade de São Paulo, indicam a solução conjunta de problemas que abrangem desde aspectos de logística de abastecimento, de trânsito de cargas no ambiente urbano até questões ligadas a aspectos econômicos da distribuição, hoje distante da prática de padrões competitivos. E sugere que caberia ao Estado cuidar de três pontos, que julga serem principais: (a) desenvolver um projeto de padrões tecnológicos de comunicação; (b) identificar áreas fora do perímetro urbano a fim de receberem postos de serviços da CEAGESP e, (c) estudar a instalação de sistemas de informações juntamente com cooperativas e centros de distribuição.

Entretanto, por mais que a privatização e o estabelecimento de um grande centro de distribuição nacional possam agradar aos mais interessados, a unanimidade não se faz presente.

FARINA et all (2000), considera que a privatização da CEAGESP não garantirá uma solução mais eficiente para o abastecimento de hortaliças. Qualquer melhoria adicional, assim entende, dependerá da definição e adoção de padrões mínimos que reduzam os custos de transação, de logística e da distribuição, uma vez que, até o presente são os próprios compradores que definem seu próprio padrão.

Considera, ainda, que a adoção de um único sistema nacional, defendida por alguns autores, poderia colocar sob monopólio as informações e comprometer a transparência dos preços, o que de certa forma já ocorre. Mas, para evitar esta situação, sugere, bastaria ao governo desenvolver mercados virtuais para que os preços se tornem públicos. Já afirmamos que a Secção de Economia e 
Desenvolvimento da CEAGESP disponibiliza em seu sítio eletrônico diariamente os preços dos produtos comercializados.

\subsection{2 - A CEAAP}

A CEAAP - Central de Abastecimento de Agroprodutores - está situada na zona cerealista da cidade de São Paulo, na rua Santa Rosa, na região do Mercado Municipal no local onde antigamente funcionava a estação ferroviária do Pari da Rede Ferroviária Federal. Exceto a aparência, o tamanho e a organização, é similar à CEAGESP em muitos aspectos, inclusive, na forma de negociação.

A administração da CEAAP está sob a direção da Associação dos Produtores de Hortaliças de São Paulo. Entidade constituída por cerca de 75 agricultores que foi criada em 1989 com a finalidade de conseguir um espaço físico onde os agricultores pudessem colocar seus produtos à venda. Naquela época, os agricultores comercializavam sua produção nas ruas ao redor do Mercado Municipal. É, portanto, um mercado de idade relativamente nova.

O objetivo foi alcançado em 2000, quando os agricultores foram transferidos para o espaço onde se encontra a CEAAP. Atualmente, uma das metas da administração é proporcionar melhoria no espaço físico da CEAAP; organizar melhor o mercado e consolidá-lo como um espaço estadual de comercialização de produtos hortifrutigranjeiros.

Logo na entrada, percebe-se uma grande movimentação de carros de passeio, peruas, peruas-kombis, caminhões grandes e pequenos transportando diversas mercadorias. Há também a movimentação de muitos carregadores que utilizam uma espécie de carrinhos de mão, apropriados, para transportar as mercadorias dos automóveis até os boxes, onde são comercializados os produtos. Há ainda um fluxo de veículos de vários municípios: Mogi das Cruzes, Suzano, Ibiúna, Sorocaba, São Roque e outros.

Depois de um certo tempo, percebe-se que existe, no mercado, uma distribuição espacial das mercadorias conforme o seu tipo. O comércio de frutas (melancia, banana, jaca, laranja e outros) se localiza logo na entrada principal do 
mercado, à direita de quem entra, mais na parte de fora dos dois primeiros galpões que se avista; à esquerda de quem entra, há outros galpões, alguns descobertos e outros semicobertos, onde estão localizados os boxes destinados ao comércio de hortaliças: alface, cebolinha, coentro, folhagens e alguns poucos "matinhos" como são chamadas as ervas, hortelã, orégano, etc. A parte destinada ao comércio de cereais (milho, arroz, grãos e farináceos) está localizada na parte exterior dos galpões, logo à esquerda de quem entra pelo portão principal.

O mercado abre às 6 horas da segunda-feira e fecha somente às 6 horas do domingo. Durante os dias da semana, o funcionamento é de 24 horas.

Os consumidores que se utilizam deste mercado são feirantes, donos de restaurantes, de bares, de hotel e de quitandas e consumidores particulares. Ou seja, é um mercado em que a maior parte do volume comercializado é realizado diretamente entre os agricultores e os consumidores, por isso, não percebemos a presença de atacadistas, nem de distribuidores para supermercados.

Dentro do mercado, há um grupo de pessoas que trabalha como segurança e são funcionários de uma empresa que é locatária do prédio. Ela é responsável pela segurança e pelo controle do fluxo de veículos que entram e saem no mercado.

Segundo o presidente da Associação, o senhor SÉRGIO MIYANO, esta empresa aluga o prédio (o espaço da antiga Estação do Pari) da Rede Ferroviária Federal e subloca os boxes para os comerciantes. Já os vendedores ambulantes e os carregadores têm que pagar uma espécie de taxa para poderem exercer suas atividades. Ela também é a responsável pela abertura e fechamento do local e pelo controle do fluxo de pessoas.

Os Boxes ou as "pedras" são muitos pequenos (cerca de dois metros quadrados) e, segundo o Sr. WILSON ${ }^{61}$, ao custo de $\mathrm{R} \$ 75,00$ por semana. Ele próprio aluga um deles. A quantidade é muito grande, cerca de 150 boxes por

\footnotetext{
${ }^{61} \mathrm{O}$ senhor Wilson era na época das nossas visitas à CEAAP o Presidente da Associação dos Chacareiros do bairro rural de Santo Ângelo. Contamos, por diversas vezes, com a ajuda dele na realização de nossas pesquisas, tanto para fazermos contato com as pessoas quanto nos acompanhando.
} 
galpão, todos muito próximos uns dos outros. É quase imperceptível o limite divisório entre um e outro boxe. Os comerciantes costumam utilizar caixotes tanto para expor as mercadorias quanto para fazer a demarcação espacial do boxe que alugam.

Os corredores são muito estreitos e causam a impressão de que o espaço já tenha se tornado insuficiente tanto para abrigar todas as instalações físicas, quanto para comportar todas as atividades que se fazem necessárias além da comercialização das mercadorias, como as de prestação de serviços, bares, restaurantes, estacionamento, etc.

Os agricultores, quando não possuem boxes, vendem as mercadorias para os comerciantes (marreteiros). Mas, quando possuem, vendem as mercadorias diretamente para os consumidores. A maioria dos agricultores, que não possuem boxes, já tem seus clientes (comerciantes) determinados. Não há uma fidelidade de venda de toda a produção para um único comerciante. $\mathrm{O}$ agricultor geralmente tem um ou mais clientes que habitualmente vende suas mercadorias. Entretanto, tem a liberdade de vender para um outro comerciante que, a princípio, não era seu cliente. O agricultor que traz uma quantidade maior que aquela combinada com o cliente, poderá vender o excesso a um outro comerciante.

O carregador tem a função de descarregar os automóveis e caminhões que chegam trazendo as mercadorias que serão comercializadas e de carregar os automóveis dos consumidores.

Segundo o senhor WILSON, eles cobram cerca de $\mathrm{R} \$ 5,00$ para descarregar um automóvel pequeno e podem cobrar até $\mathrm{R} \$ 60,00$ para descarregar um caminhão. Quem paga pelos seus serviços são os agricultores, para descarregar as mercadorias, e os consumidores para com eles circularem pelos boxes durante a compra e, depois da compra efetuada, conduzir as mercadorias até os automóveis.

Os meios de locomoção que os agricultores utilizam para transportar a produção são os mais variados possíveis. Causam a impressão de que qualquer 
tipo e tamanho de veículo pode ser utilizado: automóveis de passeio, peruaskombis, carretinhas, caminhonetes, caminhões pequenos e grandes, sendo geralmente veículos com muito tempo de uso. Isso o caracteriza como sendo um mercado utilizado, essencialmente, por pequenos agricultores.

Há mais de uma modalidade de entrega: uma é quando são os próprios agricultores que vão efetuar a entrega em seus próprios automóveis, daí a grande quantidade de pequenos veículos circulando internamente; outra modalidade é quando um agricultor traz a entrega de um ou mais agricultores. O agricultor que não tem caminhão divide as despesas de transporte com o proprietário do caminhão. Segundo o senhor WILSON, o agricultor proprietário do caminhão cobra apenas o valor correspondente aos custos da viagem, incluindo o diesel, pedágios etc. Esta modalidade é muito utilizada pelos agricultores do bairro rural Chácaras de Santo Ângelo.

Os preços dos produtos são definidos pelos comerciantes tomando como referência a quantidade e a qualidade das mercadorias que vão chegando ao mercado naquele dia, podendo apresentar grandes oscilações durante os períodos do dia. Percebemos que há uma certa especulação geral, pela manhã e tarde, em torno da qual será o preço a ser definido para cada produto.

Os preços também podem ser definidos pelos comerciantes, levando-se em consideração a expectativa sobre os impactos de algum fenômeno climático ou acontecimento econômico ou político que tenha ocorrido durante o dia anterior ou venha a ocorrer naquele mesmo dia, podendo apresentar reflexos nos dias seguintes.

Perguntamos a uma agricultora, que também possui boxe, sobre como ela determinava os preços de suas mercadorias. Ela nos disse: "Dou uma olhada pelos boxes, contando a quantidade que há das mercadorias que vendo, principalmente nos boxes que comandam determinados produtos, e vejo por quanto está sendo vendido, dependendo da quantidade e da qualidade do produto eu faço o preço". (Entrevista com a agricultora SIMONE, em 03 de julho de 2004). 
Não há um contrato formal entre o agricultor e o comerciante. O que há é uma espécie de trato, entre as partes, que funciona na base da confiança: o comerciante confia que o agricultor vai entregar as mercadorias e o agricultor, ao entregá-las, confia que irá receber o pagamento.

Segundo o senhor WILSON, tudo é feito na base da confiança, pois o agricultor terá que aguardar que o comerciante realize a venda das mercadorias, para em seguida efetuar o pagamento que, geralmente, pode ocorrer depois de uma ou mais semanas. No dia 03 de julho de 2004, por exemplo, quando estivemos no mercado, vimos o senhor Wilson entregar 100 maços de cebolinha, ao valor total de $\mathrm{R} \$ 250,00$. Ele recebeu o valor de $\mathrm{R} \$ 50,00$, correspondente a uma parte da entrega anterior, e combinaram o restante do pagamento daquela entrega e desta, para os próximos dias em que realizasse novas entregas.

Esta modalidade de contrato informal, baseado aparentemente só na confiança entre o produtor, que vende a mercadoria, e o comerciante, que a compra, sem que haja um contrato escrito, pode parecer que o agricultor ao entregar sua produção ao comerciante, sem que saiba quando vai receber o pagamento pela venda, se torne um subordinado do comerciante ao permitir que o comerciante trabalhe alguns dias com o dinheiro que lhe pertence, mas, essa é uma prática bastante comum entre os pequenos produtores e comerciantes, pouco capitalizados, na comercialização de hortaliças.

Mas, vista de mais perto, esta modalidade por ser uma prática que se repete continuadamente, sem que uma das partes rompa com o acordo, sugere que, além da confiança, exista entre as partes códigos comuns de conduta que se baseiam, fundamentalmente, na visão de mundo que cada um possui.

AZEVEDO e FAULIN (2003), ao estudarem esta modalidade de contrato, entre produtores no município de São Carlos-SP, verificou que a repetição contínua deles gera vantagens, para ambas as partes, tanto na redução dos custos de coleta de informação quanto na diminuição da possibilidade de rompimento unilateral. 
Como se percebe, este mercado é muito simples: falta-lhe uma melhor organização geral, tanto interna quanto externamente; os boxes são muito pequenos; os galpões, que abrigam as precárias instalações internas, são improvisados e alguns são descobertos, o que permite uma maior proliferação de insetos e roedores pelas instalações; se há serviço de limpeza interna, esta não se percebe, pois por todos os locais há sempre resíduos de verduras, frutas, legumes; a área destinada à praça de alimentação é muito pequena, o que torna os espaços das lojas insuficientes; a área destinada ao desembarque das mercadorias é insuficiente, assim como também o é, a destinada ao estacionamento dos automóveis. Mas, como já salientamos, o mercado ainda está em processo de organização como um sistema de abastecimento de hortaliças que deverá ser especializado na comercialização de pequenos volumes.

Entretanto, apesar dos problemas relacionados, ele é uma das poucas alternativas que os agricultores do bairro rural Chácaras de Santo Ângelo possuem para aumentar o volume de venda de sua produção no mercado paulistano e, com isso, obter renda para o seu sustento e de sua família. Seguem abaixo algumas características desse mercado que o têm tornado o mercado mais atrativo para esses pequenos produtores posseiros:

1) por estar num local da cidade de São Paulo já há muito conhecido pelos agricultores e consumidores de pequenos volumes;

2) pela economia de transporte e tempo, uma vez que o mercado está mais próximo de Mogi das Cruzes que a CEAGESP. Provavelmente, o mesmo não possa ser dito para os agricultores de Ibiúna e Piedade;

3) é um mercado que ainda está em fase de afirmação, como uma central de abastecimento de hortaliças, faltando, ainda, uma normatização própria, o que facilita a esses agricultores, a livre circulação e comercialização de sua produção no interior do mercado, sem serem importunados pelas normas, o que não ocorre nos mercados já constituídos. Vale lembrar que, esses agricultores são em sua maioria posseiros e não podem emitir nota fiscal por não possuírem documento de posse ou título da terra; 
4) a sua aparência improvisada e rústica, torna-o um mercado freqüentado por pessoas comuns e de baixa renda, cujo nível de exigência quanto à apresentação e acondicionamento do produto costuma ser menor;

5) a existência de uma infra-estrutura mínima, ainda que bastante precária, para a negociação e comercialização de sua pequena produção.

\subsection{3 - As CDR}

As CDR - Centrais de Distribuição Rural - São empresas especializadas que atuam na distribuição de hortaliças, legumes e frutas. Utilizam o espaço de grandes galpões para desempenhar suas atividades que consistem no recebimento, beneficiamento e distribuição da produção.

Como, geralmente, estão localizadas nas proximidades dos locais de produção, portanto na zona rural e, como os mercados consumidores estão sempre nos centros urbanos, distribuem as mercadorias através de caminhões que, em certos casos, podem possuir um sistema de refrigeração.

São empresas que têm todo o seu sistema de beneficiamento em conformidade com as exigências de qualidade, padronização e higiene sanitária das grandes redes de comercialização, isto é, os super e hipermercados. Esporadicamente, as redes de comercialização enviam seus técnicos e engenheiros agrônomos para fiscalizar ou verificar se as distribuidoras estão seguindo suas determinações.

A especialização que desempenham consiste num beneficiamento do produto sem alterar sua essência e forma.

No caso das CDR de hortaliças, o que se verifica é que as mercadorias passam por um processo que consiste, basicamente, numa nova lavagem; na refutação de mercadorias que apresentam folhas amareladas ou queimadas, ou com o bulbo deteriorado e no acondicionamento em embalagens em bandejas, cuja matéria-prima tem a base de isopor e a cobertura de microfilme transparente de pvc. 
Apesar da presença de muitas distribuidoras na região de Mogi das Cruzes, somente três famílias de agricultores de um total de 284 , do bairro rural de Santo Ângelo, comercializam sua produção com elas.

Procuramos saber as razões disso, com um dos agricultores, o senhor MÁRCIO BRESCIANI, ${ }^{62}$ que destina sua produção às distribuidoras, e o mesmo nos informou que os agricultores do bairro rural não tinham condições para atender às exigências destas empresas. Pois o agricultor teria que atender completamente a todos os pedidos solicitados que, na maioria dos casos, eram quantidades e variedades que ele sozinho não conseguia produzir, sendo obrigado a sair comprando de seus vizinhos, ou onde tivesse, para atender integralmente ao pedido solicitado no dia anterior.

Além disso, os pagamentos são realizados com prazos muito extensos, chegando a ter casos em que o tempo transcorrido entre a entrega das mercadorias nos distribuidores, e o recebimento do valor corresponde a 90 dias. Sendo que, ainda, há muitos casos em que o distribuidor "quebra" deixando o agricultor no prejuízo.

Além disso, identificamos uma outra razão: os distribuidores estão localizados na zona rural de outro município e sua relativa distância exige que a quantidade a ser comercializada seja grande o suficiente, no mínimo, um pequeno caminhão, para que valha a pena para o produtor percorrer a distância por estradas sem pavimentação e mal-conservadas. Diante disso, somente três famílias apresentavam, na época, condições para assumir este tipo de compromisso.

Inquirimos ao mesmo agricultor sobre os riscos que um contrato por demanda implicaria. Ao que ele nos respondeu dizendo que, como ele era agricultor e proprietário de um pequeno caminhão, assumiu o contrato confiando, não apenas na sua própria produção, mas também na de seu sogro e de seu irmão. Juntando tudo, eles eram capazes de suprir a maior parte dos pedidos.

\footnotetext{
${ }^{62} \mathrm{O}$ agricultor, no caso, foi o senhor MÁRCIO BRESCIANI que é o atual Presidente da Associação que congrega os agricultores.
} 
Segundo ele, esse contrato traria a garantia de venda da produção, embora os prazos de pagamento não sejam muito compensatórios.

HÉLIO JUNQUEIRA e ALVES LUENGO (1999), afirmam que as distribuidoras surgiram nos últimos anos e vêm se consolidando no mercado, basicamente como prestadoras de serviços aos pequenos e médios supermercados e aos restaurantes coletivos, os quais vêm praticando a terceirização das funções de aquisição de produtos hortículas e abastecimento de suas lojas e cozinhas.

Certamente, a consolidação, à qual se referem os autores acima, tenha se dado com base na subordinação imposta aos agricultores e ao acúmulo de capitais que dela resulta.

As distribuidoras que visitamos foram a Verde \& Cia, Takagaki, Kimoto, Kitazawa e Terra Nova, todas localizadas na zona rural do município de Biritiba Mirim. Elas compram as mercadorias, beneficiam e distribuem para grandes redes de supermercados do Vale do Paraíba e fundo do Vale, Baixada Santista, Região Metropolitana do Rio de Janeiro e de Belo Horizonte e de cidades localizadas no sul de Minas.

Isso contradiz o que foi afirmado por HÉLIO JUNQUEIRA e ALVES LUENGO em 1999, conforme citado. Resta verificar, a partir de quando as grandes redes de super e hipermercados nacionais, que já se submetiam na ocasião ao processo de internacionalização, passam a adotar o mesmo sistema das pequenas e médias redes.

\section{3 - As centrais varejistas}

Como vimos anteriormente, cerca de $60 \%$ da quantidade dos alimentos frescos consumidos no Brasil são comercializados na CEAGESP. Significa dizer, então, que o restante, os $40 \%$, passa por outros canais de comercialização.

Mas, mesmo os $60 \%$, como afirmaram HÉLIO JUNQUEIRA e ALVES LUENGO (1999), passam pelo CEAGESP e chegam aos atacadistas que, por sua vez, com também afirmou ZYLBERSTAJN et all (1997), reagrupam e (re) 
comercializam com os feirantes, supermercados, mercados municipais, quitandas, sacolões, varejões, etc. Assim, os chamados equipamentos, os quais preferimos denominar modalidade de comércio, são de importância fundamental para o abastecimento por constituírem a ponta final do sistema que distribui a totalidade dos alimentos.

Para dar relevo, então, a essa importância, destacaremos a seguir o sistema de distribuição de alimentos utilizado pelas principais modalidades de comércio, quais sejam as feiras livres, os sacolões, os varejões, os mercados municipais e os supermercados, existentes na cidade de São Paulo.

\subsection{1 - As feiras livres}

As feiras são, ainda hoje, a mais importante modalidade de comercialização de alimentos frescos na cidade de São Paulo, fazendo parte, inclusive, da cultura de seus habitantes. Constituem-se, tradicionalmente, como referência de qualidade e de preços no abastecimento de produtos hortifrutigranjeiros.

Os feirantes podem comprar as mercadorias de atacadistas que operam na CEAGESP ou na CEAAP ou diretamente nas centrais de distribuição ou, ainda, diretamente dos agricultores.

Atualmente, funcionam 891 feiras livres por semana a uma média de 150 diariamente na cidade de São Paulo. ${ }^{63}$

\subsection{2 - Os sacolões}

Como já vimos, foram criados em 1983 por iniciativa da CEAGESP, com o objetivo de oferta de verduras e legumes por único preço.

São grandes galpões ou prédios térreos antigos, alugados ou pertencentes a algum órgão público. Geralmente, os comerciantes compram as mercadorias de atacadistas nas centrais de abastecimento, CEAGESP, ou de distribuidores para venderem diretamente aos consumidores.

\footnotetext{
${ }^{63}$ Conforme nossa informação levantada junto à Seção de Feiras Livres da Prefeitura Municipal de São Paulo, em 13/01/2006.
} 
Atualmente, funcionam 22 sacolões na cidade de São Paulo, distribuídos pelas seguintes zonas:

Distribuição dos Sacolões na cidade de São Paulo, segundo as zonas urbanas em 2006.

\begin{tabular}{|l|c|l|}
\hline \multicolumn{1}{|c|}{ Zona } & Quantidade & \multicolumn{1}{c|}{ Bairros } \\
\hline Central & 4 & $\begin{array}{l}\text { Avanhandava, Barra Funda, Bela Vista } \\
\text { e Brigadeiro. }\end{array}$ \\
\hline Leste & 4 & $\begin{array}{l}\text { Cidade Tiradentes, Jd. S. Vicente, São } \\
\text { Miguel e Teotônio Vilela. }\end{array}$ \\
\hline Norte & 3 & Estrada do Sabão, Jaçanã e Jaraguá. \\
\hline Oeste & 5 & $\begin{array}{l}\text { Butantã, Jaguaré, João Moura, Lapa e } \\
\text { Rio Pequeno. }\end{array}$ \\
\hline Sul & 6 & $\begin{array}{l}\text { Cohab/Adventista, Grajaú, Jd. Miriam, } \\
\text { Pq. Santo Antônio, Piraporinha e Santo } \\
\text { Amaro. }\end{array}$ \\
\hline
\end{tabular}

Fonte: http://www.prefeitura.sp.gov.br/guia_serviços, em 13/01/2006.

\subsection{3 - Os Varejões}

São uma modalidade de comercialização no varejo criado pelo CEAGESP, em 1979, com a finalidade específica de oferecer produtos hortifrutigranjeiros a preços baixos.

Atualmente, na capital, funcionam no interior da própria CEAGESP três vezes por semana sendo, às quartas-feiras, das 16 às 22 horas; aos sábados, das 6 às 12 horas e aos domingos, das 7 às 13 horas. ${ }^{64}$

Os permissionários que operam nos sacolões, sob pagamento de uma taxa, compram as mercadorias nos mesmos Entrepostos $e$ as vendem diretamente para os consumidores.

\subsection{4- Os Mercados Municipais}

São pontos tradicionais de comercialização de alimentos, geralmente embutidos, latarias, cereais etc., e, com pouca exceção, de produtos hortifrutigranjeiros. Funcionam, comumente, em prédios próprios construídos em locais públicos especialmente para essa finalidade. Como as fachadas das construções dos mais tradicionais apresentam alguma beleza arquitetônica, a sua

\footnotetext{
${ }^{64}$ Há, ainda, um outro que funciona no Entreposto de Sorocaba durante os sábados, das 7 às 12 horas.
} 
visita, mesmo que só a passeio, passou a fazer parte dos costumes das populações locais.

$\mathrm{Na}$ cidade de São Paulo, são 15 os Mercados Municipais, distribuídos pelos seguintes bairros: no centro tem dois, o Central e, ao seu lado, o Cantareirinha; o de São Miguel; o da Vila Formosa; o de Sapopemba; o de Guaianazes; o da Penha; o de Tucuruvi, o da Vila Maria; o da Lapa; o de Pinheiros; o de Santo Amaro e o do Ipiranga. ${ }^{65}$

\subsection{5 - As RC}

As RC - Redes de Comercialização (super e hipermercados) são empresas que através de uma rede de lojas colocam à disposição dos consumidores uma gama muito grande de produtos de vários gêneros, qualidades, tamanhos, quantidades, etc. Para facilitar a venda, as lojas são organizadas por seção de gêneros de produtos e podem contar com ambientes climatizados, espaço para estacionamento, restaurantes, farmácias, caixas eletrônicas e uma série de outros serviços.

A seção que corresponde à exposição das hortaliças é denominada de seção de Hortifruti ou VLF (verduras e legumes frescos) e há uma pessoa, que geralmente é o promotor de vendas, portanto, funcionário cedido pela distribuidora que fornece as mercadorias, que cuida da organização, da reposição, incluindo-se o pedido de novas remessas, e da limpeza, incluindo-se as gôndolas, piso, caixas etc. 66

Mas, voltando ao sistema de abastecimento, qual é o sistema de compras que estas redes vêm se utilizando atualmente? Qual é a importância dele para os agricultores?

Como vimos, as grandes redes de comercialização estão preferindo efetuar a compra de hortaliças por via de centrais de distribuição, apesar de a

\footnotetext{
${ }^{65}$ Cf. site: http://www.prfeitura.sp.gov.br.guia_serviços, em 13/01/2006.

${ }^{66}$ Num supermercado que visitamos, o promotor estava trabalhando na limpeza de uma outra seção, por isso, deve haver casos em que os promotores, que a principio deveriam desempenhar somente tarefas relativas às hortaliças, acabam desempenhando tarefas que não lhes dizem respeito.
} 
CEAGESP, com toda sua estrutura que inclui a atuação dos atacadistas, ainda centralizar cerca de $60 \%$ do volume de hortaliças comercializado no país.

O setor das redes de comercialização vem conhecendo, nos últimos anos, um processo de internacionalização pela entrada de empresas estrangeiras no país e, principalmente na cidade de São Paulo, via compra ou fusão com as empresas nacionais. Assim, é natural que as novas empresas passem a assumir, não somente, o controle do departamento financeiro como também os de compra, de custo etc., importando sistemas de distribuição, logísticos etc. de suas sedes no exterior.

HÉLIO JUNQUEIRA e ALVES LUENGO (1999) já haviam se referido a países como a França, em que os super e hipermercados, organizados ao redor de um número muito limitado de centrais de compra, controlam cerca de $60 \%$ das vendas varejistas de hortaliças e frutas frescas, e que nos Estados Unidos, estimavam que esses estabelecimentos escoavam praticamente $95 \%$ do total das vendas de frutas, hortaliças, ervas aromáticas e flores, enquanto que o Brasil, a tendência de crescimento da participação deste setor na distribuição já podia ser verificada através de dados.

A fim de compreendermos melhor o sistema atualmente utilizado pelas grandes redes de comercialização de hortaliças, realizamos visitas, durante o mês de outubro de 2005, às seguintes redes: Carrefour, as lojas localizadas no bairro da Vila Maria e no Shopping Center Norte; Grupo Pão de Açúcar (CDB), nas lojas localizadas no bairro da Penha e MAKRO, também, no bairro da Vila Maria. Visitamos, também, em outubro de 2005, as lojas da rede Extra do Grupo Pão de Açúcar do bairro Mogilar, na cidade de Mogi das Cruzes e do bairro da Tijuca, na cidade do Rio de Janeiro. Para colhermos as informações, utilizamos o método da entrevista direta com o chefe da seção de hortifrutigranjeiros ou VLF. Na loja do MAKRO a entrevista foi com o promotor da COOPHIR, que se apresentou como o responsável pela seção de hortifrutigranjeiros. O mesmo aconteceu na loja do Carrefour do Shopping Center Norte. 
As lojas da rede Carrefour, localizadas na cidade de São Paulo, segundo as informações que foram obtidas, ${ }^{67}$ contam com uma central de compras, que está localizada em OSASCO, cidade da Grande São Paulo, que cadastra um certo número de CDR - Centrais de Distribuição Rural - de vários municípios que, sob contrato, têm a obrigação de manter um número contratado de lojas abastecidas, de acordo com os pedidos efetuados. Cada CDR, por sua vez, contrata um certo número de agricultores para fornecer as mercadorias, as quais são adquiridas com quantidade, qualidade e prazo de entrega, em conformidade com o contrato estabelecido anteriormente e com os pedidos diariamente encaminhados por cada loja do Carrefour.

Quando os agricultores entregam às CDR as mercadorias, estas, conferem o pedido e as mercadorias, imediatamente, passam por um processo de seleção e higienização e, a seguir, são acondicionadas em embalagens, conforme estabelecido tecnicamente pelo contrato do Carrefour, e após isso são entregues em cada loja pelas CDR.

Percebemos que não há uma exclusividade concedida a cada CDR, no abastecimento das lojas de uma região, isto é, nas duas lojas pesquisadas todas as mercadorias eram de diferentes marcas, embora as duas lojas se localizem muito próximas uma da outra. O promotor de vendas é o responsável pela organização e junto com o gerente da seção, faz o pedido à central, em OSASCO, que é reenviado para o fornecedor, a CDR, que efetuará a entrega durante a madrugada.

Foram verificadas as seguintes marcas, no dia $28 / 10 / 05^{68}$ :

\footnotetext{
${ }^{67}$ Fomos atendidos pelas seguintes pessoas: na loja da Vila Maria, pelo chefe da seção EDIVALDO, e da do Shopping Center Norte pelo senhor JORGE MARQUES AZEVEDO, promotor da L.S. Verduras Selecionadas, em 28/10/2005.

${ }^{68}$ Tem que se considerar que os tipos ofertados num determinado dia podem variar no seguinte, pois a oferta varia de acordo com a procura e com o fornecimento das CDR. O mesmo argumento, serve para todas as lojas e redes.
} 
Rede CARREFOUR - Lojas da Vila Maria e Shopping Center Norte.

\begin{tabular}{|l|l|l|c|l|}
\hline \multirow{2}{*}{ Tipo } & \multicolumn{2}{c|}{ Vila Maria } & \multicolumn{2}{c|}{ Shopping Center Norte } \\
\cline { 2 - 5 } & Marca & Procedência & Marca & Procedência \\
\hline Tradicional & Hasegawa & Biritiba Mirim & L.S. Verd. Selecionad. & V. Gde. Paulista \\
\hline Hidropônica & Kisalada & São Roque & L.S. Verd. Selecionad. & V. Gde. Paulista \\
\hline Orgânica & Horta e Arte & São Roque & L.S. Verd. Selecionad & V. Gde. Paulista \\
\hline
\end{tabular}

Fonte: Dados da pesquisa - 28/10/05

Nas lojas da rede Extra do Grupo Pão de Açúcar, o sistema utilizado é muito semelhante, para não dizer igual, ao da rede Carrefour. Nas lojas das três cidades pesquisadas, São Paulo, Mogi das Cruzes e Rio de Janeiro, encontramos o mesmo sistema.

O promotor, que nessa loja parece ter mais atribuições que o do Carrefour, pois além de abastecer e controlar a qualidade também ajuda na limpeza das gôndolas, do piso, etc., faz juntamente com o gerente o pedido de novas remessas para a central de compras, que informa ao fornecedor a quantidade desejada de cada loja e, esse, logo pela manhã, efetua a entrega em cada loja. $^{69}$

Na loja do Grupo Pão de Açúcar do bairro da Tijuca, só encontramos hortaliças do tipo tradicional, sendo que só havia uma única marca (Manuel Pinto Ribeiro Leal), cuja origem era da região de Teresópolis. ${ }^{70} \mathrm{O}$ mesmo ocorrendo com as lojas de Mogi das Cruzes e da Penha.

\footnotetext{
${ }^{69}$ As informações foram obtidas com o chefe de Seção senhor Paulo Roberto e com o funcionário Reginaldo, no dia $11 / 10 / 05$.

${ }^{70}$ Tivemos a oportunidade de visitar esta região e aproveitamos para realizar duas entrevistas, uma com o senhor VAIMIL e a outra com o senhor LUÍS GERALDO. São pequenos produtores que comercializam com centrais de distribuição rural, no município de Venda Nova cortada pela Rodovia Teresópolis-Friburbo. Esta região Serrana do Estado do Rio de Janeiro, vem progressivamente aumentando a produção de hortaliças e o abastecimento da cidade do Rio de Janeiro e, em função disso, passou a substituir a produção das empresas da região de Mogi das Cruzes.
} 


Rede EXTRA - Lojas do Mogilar (Mogi das Cruzes) e da Penha (São Pau
\begin{tabular}{|c|c|c|c|l|}
\hline \multirow{2}{*}{ Tipo } & Mogi das Cruzes (Mogilar) & \multicolumn{1}{|c|}{ Penha (São Paulo) } \\
\cline { 2 - 5 } & Marca & Procedência & Marca & Procedência \\
\hline Tradicional & Hasegawa & Biritiba Mirim & Mr. Valley & Ibiúna \\
\hline Hidropônica & Hasegawa & Biritiba Mirim & Kisalada & São Roque \\
\hline
\end{tabular}

Fonte: Dados da pesquisa - 11/10/05

Nas duas lojas não havia, na ocasião, hortaliças para atender a outros segmentos, como, por exemplo, o orgânico. Perguntamos qual o motivo ao chefe da Seção, o senhor PAULO ROBERTO, e o mesmo informou que para os demais segmentos a loja não oferecia porque não havia procura.

Já na loja da Vila Maria da rede MAKRO, o sistema utilizado ainda é o tradicional, isto é, cada loja cadastra os fornecedores (os quais pagam uma taxa individual de $\mathrm{R} \$ 10.000,00$ ) para fazer uso das instalações (nesta loja as hortaliças são expostas em gôndolas refrigeradas). O fornecedor é responsável pelo abastecimento de cada loja e é obrigado a manter um promotor que tem a função de organizar, repor e informar ao gerente a necessidades de novos pedidos. Cabe, ainda, ao fornecedor efetuar um pagamento ao supermercado, que corresponde a $3 \%$ sobre o total das mercadorias entregues e vendidas, correspondente ao total de perdas que o supermercado acumulou ao longo de 30 dias.

\begin{tabular}{|l|c|c|}
\multicolumn{2}{c}{ Rede MAKRO: Loja da Vila Maria } \\
\begin{tabular}{|l|c|c|}
\hline Tipo & Marca & Procedência \\
\hline Tradicional & COPHIR & Ibiúna e região \\
\hline
\end{tabular}
\end{tabular}

Fonte: Dados da pesquisa - 28/10/05

Nesta loja, só havia hortaliças do tipo tradicional e única marca ofertada era a da COPHIR - Cooperativa dos Produtores de Hortaliças de Ibiúna e Região. $^{71}$

Sob o ponto de vista da subordinação, tanto para as centrais de distribuição quanto para os agricultores, nos dois sistemas ela é dominante. Se

\footnotetext{
${ }^{71}$ As informações foram obtidas com o promotor da COPHIR o senhor SIDNEY VIEIRA DOS SANTOS, em 28/10/05.
} 
bem que, no caso do sistema utilizado pelas lojas da rede MAKRO, a subordinação sobre as centrais de distribuição é ainda maior porque além do pagamento da taxa de cadastro, que corresponde a $R \$ 10.000,00$, o agricultor arca com a despesa pelo prejuízo que o supermercado tem ao mês, correspondente a $3 \%$ sobre o volume entregue pela cooperativa e comercializado pelo supermercado.

Já vimos como estas empresas exploram os agricultores da região de Mogi das Cruzes e Biritiba Mirim, impondo a eles contratos e condições que nem sempre conseguem cumprir. Por outro lado, elas também estão subordinadas às condições de exploração por parte das grandes redes. Haja vista que muitos contratos, entre as redes e as distribuidoras, exigem que estas últimas diminuam, pela metade, os preços das mercadorias durante os dias da semana quando ocorrem as promoções que se realizam, geralmente, às quartas e sextas-feiras, a já conhecida "feirinha", em todas as lojas dos supermercados.

De qualquer modo, se por um lado, o sistema utilizado pelas redes de comercialização, tem sempre por objetivo a eficiência e a competitividade que se traduzirão no giro rápido de mercadorias, eliminando custos de manutenção de áreas de recebimento, de depósitos, de grandes estoques de produtos, de funcionários, etc., por outro, a utilização de sistemas racionais, próprios do modo de produção capitalista, é adotada para dar continuidade ao processo de subordinação do capital sobre a produção agrícola, que ora a produção é subordinada à circulação, ora a circulação é subordinada à produção.

Para sabermos a quantidade de lojas existentes, recorremos às informações da APAS - Associação Paulista de Supermercados - que divulgou em seu sítio eletrônico um Estudo ${ }^{72}$, encomendado à $A C$ Nielsen, o qual revelou que o Estado de São Paulo contava com 4.764 empresas de auto-serviço (super e hipermercados), das quais 1.371 estavam situadas na Grande São Paulo, somando 5.913 lojas, áreas de vendas superiores a 3,5 milhões de metros quadrados e 31,2 mil checkouts (caixas de recebimentos). O Censo revela

72 As informações foram colhidas através do sítio eletrônico da APAS: http://www.apas.com.br/dados mercado.cfm em 14/01/2006. O estudo foi realizado com empresas que tinham no mínimo 2 checkouts. 
também que $76,4 \%$ das lojas abrem aos domingos e $90 \%$ praticam a entrega em domicílio e apresenta um quadro comparativo entre os anos de 1997 e 2000, sobre as informações divulgadas, o qual foi reproduzido abaixo:

Estudo sobre a evolução das empresas de auto-serviço,
realizado por AC NIELSEN, encomendado pela APAS.
\begin{tabular}{|l|r|r|r|}
\hline \multicolumn{4}{|c|}{ CENSO APAS COMPARATIVO } \\
\hline \multicolumn{2}{|c|}{ ANO 1997 } & \multicolumn{1}{c|}{ ANO 2000 } & \multicolumn{1}{c|}{$\%$} \\
\hline Número de Empresas & 4.681 & 4.764 & 1,77 \\
\hline Número de lojas & 5.762 & 5.960 & 3,44 \\
\hline Metragem & 3.346 .569 & 3.573 .162 & 6,77 \\
\hline Checkout & 31.013 & 21.231 & 7,03 \\
\hline Número de Empregados & 160.329 & 176.319 & 10,0 \\
\hline $\begin{array}{l}\text { Abertura de lojas aos } \\
\text { domingos }\end{array}$ & 52,8 & 76,4 & 44,7 \\
\hline
\end{tabular}

Fonte: http:/www.apas.com.br/dados_econmico.cfm de 16/01/2006.

Os dados demonstram que ocorreu um aumento de 83 novas empresas no mercado, entre 1997 e 2000, enquanto a quantidade de lojas, que em 1997 era de 5.762, subiu para 5.960, em 2000, representando um aumento real de 198 novas lojas, o que está relacionado com o aumento das instalações, da quantidade de funcionários e de lojas que funcionam aos domingos.

\section{4 - A internacionalização das RC}

SAAB et all (2000), considera que, a partir da década de 90, houve uma grande expansão por parte das empresas líderes no mercado, quando passaram a utilizar duas formas para manterem suas posições: (a) abertura de novas lojas por meio de construção e (b) compra de cadeias menores já instaladas.

Esta última forma, a aquisição de pequenas cadeias, foi a mais utilizada pelas grandes redes. Somente durante o ano de 2000, a rede Carrefour adquiriu duas redes paulistas: a BIG BOM e a ANTONELLI, que, juntas, apresentaram faturamento em torno de 53 milhões de reais, enquanto que a Companhia Brasileira de Distribuição (GRUPO PÃO DE AÇÚCAR), adquiriu, só para citar o Estado de São Paulo, a PAULO J. REIMBERG, com nove lojas, a NAGUMO, com 12, os supermercados ROSADO, com 13, e as lojas das redes GEPIRES e da CIBUS/IPANEMA, que não foi possível determinar a quantidade de lojas de cada 
uma. Anos antes, este Grupo já havia adquirido cerca de três lojas da rede SHIBATA e uma da MOGIANO, na cidade de Mogi das Cruzes.

Mas, além dessas aquisições, os investimentos prosseguiram durante 0 ano de 2003: enquanto o Carrefour anunciava, em 17/03/2003, que destinaria 600 milhões de reais para a abertura de mais sete hipermercados, o GRUPO PÃO DE AÇÚCAR, em 16/04/2003, divulgava que investiria nesse mesmo ano os valores de $\mathrm{R} \$ 240$ milhões para a abertura de novas lojas; R\$ 200 milhões na modernização de suas lojas; $\mathrm{R} \$ 70$ milhões nos setores de tecnologia e logística do grupo e mais $\mathrm{R} \$ 30$ milhões para outros investimentos, como aquisições, por exemplo. $^{73}$

Há ainda, as demais redes que também como as grandes, passaram a ampliar a rede de comercialização no varejo: em 04/12/2003, a rede SMART anunciou a abertura de 130 lojas só na região metropolitana de São Paulo; em 13/10/2003, a CHAMPION abriu mais duas, subindo para 114 o total de suas lojas, também na grande São Paulo em 18/06/2003. Em 26/11/2004, a rede SONDA anunciava sua expansão de seus postos de venda com a inauguração de mais nove novas lojas, sendo programado a abertura de mais quatro lojas, sendo inclusive uma delas virtual, para o ano de 2005 e, 02/03/2006, a rede WALT MART anunciou a compra do BOMPREÇO, do Nordeste, e com esta aquisição passa a ocupar a terceira posição no ranking brasileiro de supermercados. ${ }^{74}$

SAAB et all, considera que a partir destas aquisições, os grupos estrangeiros passaram a dominar o mercado, uma vez que, seis dentre os sete grupos, pertencem ou possuem participação estrangeira e somente um apresenta capital sem a participação estrangeira. Assim, o setor de maior distribuição de alimentos no país passou a ser internacionalizado e, com isso, dependente do capital estrangeiro como vários setores da economia nacional.

A tabela abaixo, mostra como ficou a posição no ranking brasileiro, o faturamento em 1999 e a origem do capital de cada grupo.

\footnotetext{
73 Cf. NOTÍCIAS APAS, link Informações do sítio eletrônico do APAS: http://www.apas.com.br em 14/01/2006. (foram consultados os boletins mensais dos anos de 2003 e 2004).

${ }^{74}$ Idem.
} 
Origem do Capital das Maiores Empresas

\begin{tabular}{|l|l|c|c|}
\hline Posição & \multicolumn{1}{|c|}{ Grupo } & $\begin{array}{c}\text { Faturamento } \\
1999 \\
\text { (R\$ bilhões) }\end{array}$ & Origem do capital \\
\hline $1^{\mathrm{a}}$. & Carrefour & 7,94 & francês \\
\hline $2^{\mathrm{a}}$. & CBD & 7,76 & brasileiro/francês \\
\hline $3^{\mathrm{a}}$. & Sonae & 2,85 & português \\
\hline $4^{\mathrm{a}}$. & Bompreço & 2,64 & holandês \\
\hline $5^{\mathrm{a}}$. & Sendas & 2,38 & brasileiro \\
\hline $6^{\mathrm{a}}$. & Wal Mart & 0,96 & amaericano \\
\hline $7^{\mathrm{a}}$. & Jerônimo Martins/Sé Superm & 0,71 & português \\
\hline
\end{tabular}

Fonte: Abras (Cf. SAAB et all, 2000, pág.3).

Já vimos, nos itens anteriores, que o quadro atual do sistema de abastecimento da CEAGESP demonstra uma tendência de as grandes redes de comercialização renunciarem lentamente a compra de hortaliças via CEAGESP e passarem a operar, cada vez mais, pelo sistema de compra via distribuidora.

HÉLIO JUNQUEIRA e ALVES LUENGO (1999), ao se referirem ao novo papel que o varejo vem desempenhando na cadeia de distribuição, afirmam que o segmento distribuidor (quer dizer as redes de super e hipermercados) capitaliza grandes vantagens por ser o detentor de um relacionamento privilegiado com os consumidores, na medida em que é capaz de receber e processar informações de tendências e de alterações nos hábitos de consumo, antes de qualquer outro elo da cadeia. Tal fato confere às redes uma posição estratégica no setor, colocandoas na vanguarda dos processos de alimentação do fluxo de informações e de coordenação da cadeia agroalimentar.

Consideram, ainda, que as redes para se manterem em tal posição, passaram a comercializar hortaliças segundo a demanda de cada segmento de mercado. É sobre este tema que vamos direcionar nossas discussões a seguir.

\section{5 - Os segmentos de mercados}

ALVES LUENGO e HÉLIO JUNQUEIRA (1999), consideram que, até o final da década de 90, havia a oferta no mercado brasileiro de sete segmentos diferenciados de hortaliças, além da convencional. Tal diversificação era decorrente da crescente demanda do mercado por alimentos saudáveis e práticos e pela maior participação da mulher no mercado de trabalho, o que acarreta um 
menor tempo disponível para as atividades domésticas, principalmente para o preparo de alimentos. Este contexto, segundo entendem, se traduziu no maior consumo de refeições realizadas fora de casa e na demanda por produtos de preparo mais rápido.

São os seguintes os segmentos de mercado verificados por HÉLIO JUNQUEIRA e ALVES LUENGO, em 1999: além das convencionais, destacam-se os segmentos das hortaliças não-convencionais; das supercongeladas e geladas; das minimamente processadas; das enlatadas ou em conserva; das desidratadas e liofilizadas; das orgânicas e das irradiadas.

\subsection{1 - Das não-convencionais}

Corresponde ao cultivo e à oferta de hortaliças exóticas, americanas ou européias, para atender um segmento do mercado constituído pelo consumidor que busca novidades, mas que não abre mão do consumo in natura. A diferenciação, nem sempre está associada à introdução de novas espécies, mas apenas ao cultivo de espécies com variações com relação à coloração, como é o caso da alface e quiabos roxos, berinjela branca, abobrinha amarela e pimentões coloridos; ou de tamanho, como é o caso da mini-cenoura (baby-carrot), do agrião (cressonete), da cebola (echalottes) e da alface (lolo red).

HÉLIO JUNQUEIRA e ALVES LUENGO consideram que as principais hortaliças exóticas introduzidas recentemente na agricultura brasileira são as endíveas, que são chicórias amargo-adocicadas, a mache, que é alface de folhas pequenas e arredondadas, o radicchio, que é uma escarola crespa e clara no centro da cabeça, a alface 'red fire', que é uma alface de folhas crespas e avermelhadas. (Idem, pág. 2).

E que, enquanto, o consumo de tais hortaliças vem apresentando um notável crescimento no país, tanto por meio de importação quanto da produção interna, o mesmo não se verifica em relação às hortaliças tradicionais, como o caruru, a taioba, a groselheira e outras. Para estas últimas, a importância deverá, ainda nos próximos anos, se manter circunscrita às demandas fomentadas pelos programas regionais de educação e assistência às populações carentes. 


\subsection{2 - Das supercongeladas e geladas}

No Brasil, o ramo de alimentos congelados, de forma geral, foi o que mais se beneficiou com a estabilidade econômica, contabilizando índices anuais de crescimento, em 1994, em torno de $9 \%$ em volume e de $1,7 \%$ em faturamento. $E$ as tendências recentes apontam para uma elevação de consumo, embora o consumo interno anual ainda seja inexpressivo se comparado aos padrões internacionais (4,3 milhões de toneladas nos Estados Unidos; 1,2 na Europa e 80,2 mil no Japão).

A Cooperativa Agrícola de Cotia foi pioneira, quando em 1987, lançou nos supermercados batatas pré-fritas congeladas, com a marca Bint. A partir dos anos 90 começou a surgir um maior número de iniciativas setoriais, com a instalação de fábricas nacionais e de escritórios de representação comercial de empresas mundiais de porte nesse ramo.

Como observa HÉLIO JUNQUEIRA e ALVES LUENGO "O consumo interno é crescente, influenciado por fatores tais como o aumento do poder aquisitivo, a demanda por produtos mais práticos e a ampliação do número de lojas de conveniência, que se encaixam no perfil de um varejo moderno, onde os supercongelados são itens representativos. A expansão nas vendas de eletrodomésticos, como freezers e fornos microondas, também constitui forte indicador de tendências do aumento de consumo dos alimentos supercongelados e gelados. Contudo, esta demanda está, ainda, em fase de consolidação, sofrendo grande influência da oferta e dos preços do produto in natura. Além disso, prevalece um relativo desconhecimento na conservação e preparo daqueles alimentos". (1999², pág. 3).

O mercado de hortaliças congeladas ainda tem como líder de vendas as batatas, com diversas variedades, finalidades e cortes, mas a oferta de outros produtos, como os brócolis, milho doce, ervilha, cenoura, mandioca, vargem e outras hortaliças têm aumentado significativamente, em função, sobretudo, das novas tecnologias disponíveis. 


\subsection{3 - Das minimamente processadas}

HÉLIO JUNQUEIRA e ALVES LUENGO consideram que este tipo de segmento detém os atributos da conveniência e da qualidade dos alimentos frescos, sendo seu principal propósito o de fornecer e disponibilizar um produto pronto para o uso, sem necessitar de nenhuma preparação posterior, em termos de seleção, limpeza, lavagem ou cortes. Mas, são geralmente mais perecíveis do que os convencionais, em função da incidência de maiores taxas de respiração dos alimentos assim processados, levando a uma intensificação das reações químicas associadas à sua deterioração, uma maior proliferação bacteriana, e à intensificação da evaporação de água, conduzindo a uma aceleração do murchamento das hortaliças. (págs. 3 e 4 ).

Uma explicação sobre como ocorre o processo de modificação da atmosfera, foi dada por OMATI e GODOY (1996):

A embalagem de atmosfera modificada é uma técnica de preservação de alimentos cada vez mais popular, onde a composição da atmosfera ao redor do alimento é diferente da composição normal do ar. Em alguns aspectos, a embalagem a vácuo é semelhante à da atmosfera modificada, sendo a principal diferença o fato de que, nestas últimas, existe a remoção da maior parte do ar de dentro da embalagem, sem a substituição por uma outra mistura gasosa. Na modificação da atmosfera, a mistura de gases deve ser escolhida conforme as necessidades específicas do produto alimentício. Na maioria das aplicações, essa mistura é uma combinação de dióxido de carbono, oxigênio e nitrogênio. (Cf. HÉLIO JUNQUEIRA e ALVES JUENGO, $1999^{2}$, págs. 3 e 4).

Consideram ainda que, apesar de algumas instituições importantes (Instituto de Tecnologia de Alimentos-ITAL, a Embrapa Hortaliças, a Embrapa Agroindustrial de Alimentos, a Universidade Federal de Viçosa, a UNESP de Jaboticabal) terem desenvolvido projetos sobre hortaliças minimamente processadas, aumentando, inclusive, o prazo de validade dos alimentos para 10 a 15 dias, ainda não se venceu todas as dificuldades, como a utilização de equipamentos e sanitizantes inadequados para a higienização, o controle deficiente da qualidade da água empregada, o longo tempo entre a colheita e o 
processamento ideal em toda a cadeia, desde a produção até a distribuição final etc.

\subsection{4 - Das enlatadas ou em conserva}

Este segmento é, praticamente, exclusividade do tomate. Como líder absoluto do processamento de hortaliças no Brasil, os seus derivados compuseram um mercado em torno de US\$ 682 milhões, em 1998, e de aproximadamente de US\$800 milhões, em 2000.

Os derivados do tomate constituem duas linhas de processamento: os mais simples, que são também os mais consumidos, como os extratos, purês e polpas, e os mais elaborados, como os molhos prontos e os katchups.

Geralmente, neste segmento as empresas realizam os contratos diretamente com os agricultores, gerando por um lado, o planejamento e a continuidade do abastecimento do produto processado durante todo ano, independentemente da sazonalidade, mas por outro, gera a subordinação dos agricultores às indústrias, visto que são elas próprias quem determinam a qualidade, tamanho e aparência; o preço e a quantidade a ser comprada.

\subsection{5 - Das desidratadas e liofilizadas ${ }^{75}$}

O método da desidratação de hortaliças vem sendo utilizado largamente na industrialização de alimentos. A utilização vem ocorrendo, principalmente, na obtenção de:

- corantes naturais de massas, iogurtes e sorvetes, cuja base se obtém através da beterraba, do espinafre, do tomate e a cenoura;

- condimentos e temperos em molhos, patês, queijos, pães, tortas, biscoitos, recheios e embutidos cuja matéria-prima utilizada é a cebola, a salsa, a cebolinha, o alho-poró e o pimentão;

- purês, pães, sopas, tortas, biscoitos e salgadinhos que são produzidos a partir de batatas, mandioquinha e salsa;

\footnotetext{
75،"Processo de secagem e eliminação de substâncias voláteis realizado em temperatura baixa e sob pressão reduzida”. Cf. Holanda Ferreira, A. B. MINI AURÉLIO, 2000, pág. 428.
} 
- cubos, flocos, ou pó em molhos, sopas e acompanhamento de produtos cárneos que são obtidos através da batata, cenoura, abobrinha, couve, repolho e pimentão.

As maiores consumidoras de hortaliças desidratadas são as empresas de processamento de refeições coletivas, sendo o molho de tomate em pó, a batata em flocos, sopas, caldos e molhos os mais utilizados.

ALVES LUENGO e HÉLIO JUNQUEIRA (1999) observam que no varejo, a tendência do mercado é o aumento no volume, na qualidade e nas formas de apresentação de diversos itens de utilização básica, tanto para atender a demanda das indústrias de refeições, quanto pelos consumidores que utilizam as hortaliças desidratadas no preparo doméstico de temperos e condimentos.

\subsection{6 - Das orgânicas}

O mercado para hortaliças orgânicas já é um fenômeno reconhecido e, de certo modo, consolidado no país, muito embora a produção se destina a apenas uma fatia muita pequena do mercado consumidor.

ALVES LUENGO e HÉLIO JUNQUEIRA (1999) consideram que na cidade de São Paulo, o comércio de hortaliças orgânicas já ultrapassava, em 1999, a marca de US\$ 2 milhões por ano. Sendo as redes de supermercados as principais distribuidoras com cerca da metade do volume comercializado.

Consideram ainda que este segmento é bastante lucrativo para toda cadeia, pois os preços chegam a alcançar até $30 \%$ a mais que as hortaliças convencionais, compensando os possíveis gastos com os custos adicionais provocados pela obtenção da certificação ${ }^{76} \mathrm{e}$ da menor produtividade.

Entretanto, há inúmeras limitações à expansão da agricultura orgânica: sua baixa produtividade, o aspecto diferenciado dos produtos (produtos menores, manchados, com insetos, etc.) e seus preços sobrevalorizados se comparados às hortaliças convencionais.

\footnotetext{
${ }^{76}$ Atualmente são duas empresas que concedem certificações: O Instituto Biodinâmico, em Botucatu-SP e Associação de Agricultura Orgânica.
} 


\subsection{7 - Das irradiadas}

Este segmento corresponde à preservação das hortaliças por ionização, usando raios $\mathrm{X}$ e raios $\mathrm{Y}$. É muito similar ao processo de pasteurização ou esterilização que se aplica quase a todos os alimentos. Devido à sua eficácia, que além de não deixar nenhum vestígio inibe o brotamento e o amadurecimento, foi aprovado pela Organização Mundial da Saúde e pela Organização das Nações Unidas para a Agricultura e Alimentação - FAO, 1983.

A adoção de tal técnica para o Brasil, que possui climas tropicais, elevados índices de perdas de alimentos e onde as condições ambientais são mais propensas à rápida deterioração dos produtos perecíveis, seria bastante oportuna, segundo ALVES LUENGO e HÉLIO JUNQUEIRA. Até porque, os custos de aplicação da técnica são bastante reduzidos e o consumo elevado de brometo de metila, utilizado na fumigação para combater larvas e microorganismos a um preço baixo, deverá ser eliminado da agricultura brasileira até 2010, em obediência ao Protocolo de Montreal a qual o Brasil é um dos signatários.

Os agricultores, de pequenas unidades, que dependam da venda da produção para a manutenção econômica sua e da família nem sempre têm a compreensão de que a fase de comercialização é uma etapa importante para se aumentar a rentabilidade econômica. Embora, a grande maioria dos agricultores disponha em sua residência de aparelhos domésticos, como rádio e televisor, que Ihe permitem obter informações sobre o mercado, muitos, ainda, são analfabetos e nem sempre conseguem decodificar as informações recebidas. ${ }^{77}$

Entretanto, não se trata de se pensar que todo agricultor, de hoje, vai se transformar em um produtor, informado, especializado e com visão empresarial amanhã, por mais numerosos que sejam os canais de informações. Mas, por outro lado, os agricultores têm provado, pela sua existência, que conseguem lidar com o mercado mesmo que seja na situação de subordinação.

Dessa forma, é fundamental que se incentive entre os agricultores formas de comercialização como as associações ou cooperativas, permitindo assim uma

\footnotetext{
77 Esta é a realidade dos agricultores do bairro de Santo Ângelo. Através de pesquisa, constatamos que aproximadamente $90 \%$ têm televisores e um pouco mais da metade é alfabetizada.
} 
atuação coletiva, com base em orientações de profissionais qualificados. Isso ajudaria a evitar, por um lado, perdas econômicas como a concorrência entre eles mesmos, a atuação de atravessadores aproveitadores, os elevados custos de produção, o aviltamento dos preços, etc., e, por outro, ajudaria na conquista de ganhos técnicos como, por exemplo, a socialização de informações sobre as tendências do mercado, que atinge atualmente todos os setores da agricultura e, em especial, a cultura de hortaliças, o que abriria possibilidades para que os agricultores tivessem novas alternativas e pudessem destinar parte da produção para atender certos segmentos específicos do mercado. É claro, que tudo isso só seria possível se a associação ou cooperativa pudesse contratar técnicos profissionais que orientassem os agricultores em face dos riscos existentes. Mas, quanto aos riscos? Ora, todos sabemos que a produção agrícola, em si mesma, é uma atividade altamente arriscada.

\section{6 - Um esboço explicativo}

\section{Esboço da Organização do Mercado de Hortaliças}

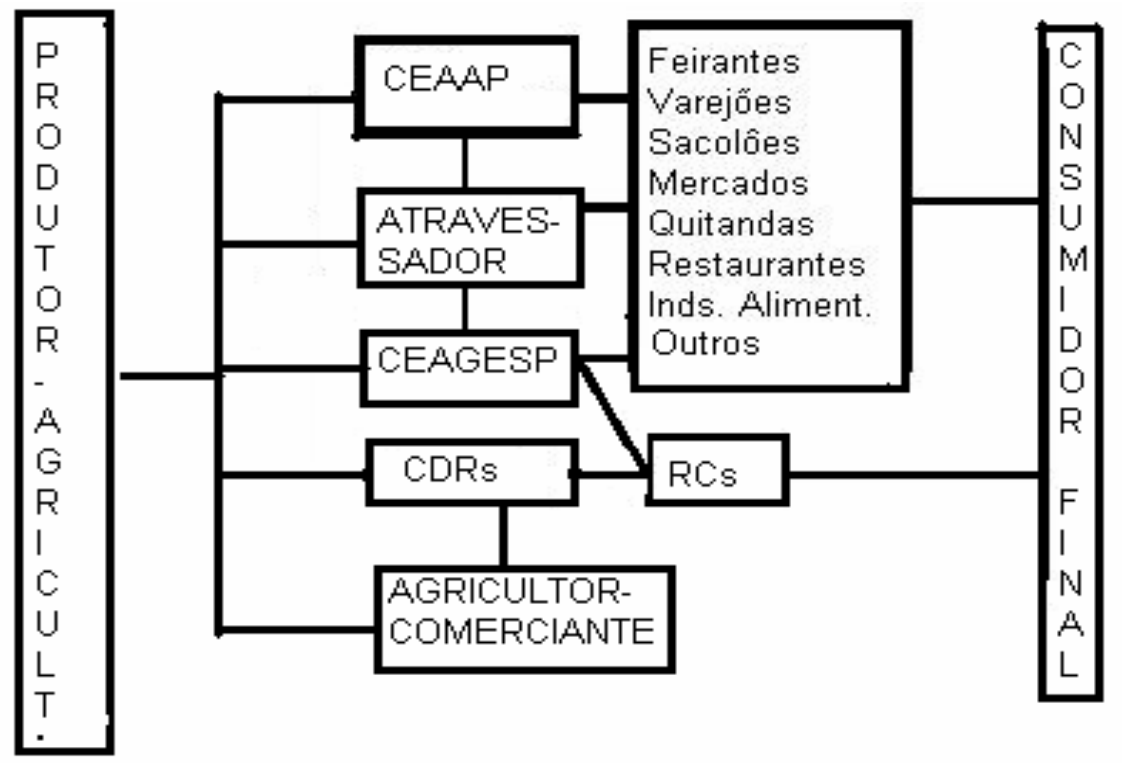




\section{Legenda}

CEAAP - Central de Abastecimento AgroProdutor.

CEAGESP - Cia. De Entrepostos e Armazéns Gerais do Estado de São Paulo.

CDRs - Centrais de Distribuição Rural

RCs - Redes de Comercialização

Agricultor-comerciante - aquele que, eventualmente, compra mercadorias para complementar com a sua produção o pedido de seus clientes que geralmente são as CDRs.

Assim, a partir de tudo que vimos, elaboramos um esquema simplificado para representar o atual mercado de hortaliças da cidade de São Paulo. Podendo ser explicado do seguinte modo:

I - os produtores/agricultores vendem sua produção para os atacadistas do CEAGESP e do CEAAP e para as CDR, que são os principais centros de abastecimento atacadistas, e também para as RC (redes de comercialização), para atravessadores e agricultores-comerciantes;

II - os atacadistas do CEAGESP e CEAAP adquirem mercadorias para venderem aos comerciantes dos mercados varejistas, isto é, aos feirantes, varejões, sacolões, Mercados, quitandas, restaurantes e indústrias de refeições e de processamento de alimentos enlatados, em conserva, congelados, além dos consumidores finais;

III - os atravessadores, que além de adquirem mercadorias dos produotores/agricultores e dos atacadistas, também, vendem suas mercadorias para os comerciantes do mercado varejista, isto é, feirantes, varejões, sacolões, etc.;

IV - as CDR, que além dos produtores/agricultores, também adquirem mercadorias dos agricultores-comerciantes que, após processadas, vendem para as redes de super e hipermercados (as RC);

$\mathrm{V}$ - e, finalmente, as RC que, após o recebimento das mercadorias em suas lojas, vendem aos seus consumidores. 


\section{CONCLUSÃO}

O desenvolvimento da agricultura brasileira se realizou sob o modo de produção capitalista. O período do regime militar é um marco nesse processo. Em 1964, o governo federal passou a conceder benefícios fiscais aos grandes proprietários para aquisição de máquinas e insumos agrícolas e promulgou o Estatuto da Terra, Lei $n^{\circ} 4.504$. Essa lei visava, prioritariamente, a modernização do campo mediante o aumento da produção e da produtividade a fim de combater as constantes crises causadas pela falta de abastecimento de produtos agrícolas nos centros urbanos.

Este processo resultou na industrialização da agricultura com a participação significativa de grandes empresas, na concentração das terras e da renda e na expropriação de camponeses e aumento da exploração dos trabalhadores do campo. Uma de suas principais conseqüências foi a transferência compulsória de milhares de trabalhadores rurais para os centros urbanos e o agravamento dos problemas relacionados ao abastecimento alimentar nas cidades.

O padrão da modernização que se adotou na agricultura brasileira se completaria, portanto, com a reorganização do sistema de abastecimento alimentar, o que de fato ocorreu. Após 1964, o governo federal passou a controlar os preços em toda cadeia produtiva, como também a oferta através da intervenção direta no atacado e no varejo de alimentos.

Em 1968, foi instituído o GEMAB - Grupo Executivo de Modernização do Abastecimento-, que tinha por objetivo a criação de um sistema de intervenção direta no comércio de alimentos. O sistema criado, o SINAC - Sistema Nacional e Centrais de Abastecimento -, que seria coordenado pela COBAL - Companhia Brasileira de Alimentação -, teria a responsabilidade de implantar centrais de abastecimento nas capitais e nos principais núcleos urbanos. O modelo sugerido pela GEMAB resultou na construção de dezenas de CEASA's - Centrais de Abastecimento - no período entre 1972 e 1979. Na década de 80, foram implantadas mais 47 CEASA's, sendo treze delas pertencentes à rede estadual do 
CEAGESP - Companhia de Entrepostos e Armazéns Gerais do Estado de São Paulo -, que foi o pioneiro na introdução do programa de centrais de abastecimento.

Com a expansão das CEASA's, o setor da agricultura que respondia pela produção de alimentos frescos, entre os quais o hortifrutigranjeiro, torna-se mais atraente para os produtores capitalistas. Além do mais, ao ser responsável pela alimentação de uma parte significativa da população do país, residente nos grandes centros urbanos, este setor passou a representar um dos pilares da chamada "questão de segurança alimentar".

Com isso, o modo de produção capitalista expandiu ainda mais suas relações de trabalho na agricultura brasileira promovendo, inclusive, a modernização da produção de hortifrutigranjeiros por intermédio da especialização dos agricultores. Entretanto, tais relações de trabalho não chegaram a homogeneizar completamente todo setor hortifrutigranjeiro do país, visto que ainda é identificada no campo a produção familiar, que permanece existindo neste e em outros setores da agricultura.

No bairro de Santo Ângelo, pode se verificar a existência da produção familiar e de um modo de vida que, apesar de suas singularidades, aponta, ao nosso ver, para um processo de construção de um bairro rural. São indicativos deste processo a existência do sentimento de pertencimento e a concepção da terra como terra de trabalho e de reprodução da família, dentre outros elementos identificados. Essa concepção é a base de um modo de vida que é contraditório aos valores capitalistas, que se baseiam em relações sociais definidas pelo mercado.

Os agricultores de Santo Ângelo constituem um grupo em que as relações sociais guardam similaridades com aquelas existentes nos antigos bairros rurais paulistas. O sentimento de pertencimento ao lugar é disseminado entre todos; 0 trabalho familiar é a base da produção entre a maior parte das famílias agricultoras, embora eventualmente se possa empregar mão-de-obra assessória, e a prática da ajuda mútua ainda ocorre entre os agricultores mais antigos. 
Esses agricultores estão subordinados ao mercado e, no interior do bairro, pode-se observar um processo de diferenciação social em curso. Como orientam sua produção para o mercado, eles se submetem às regras do jogo capitalista e se sujeitam à exploração dos atravessadores e atacadistas que operam nas centrais de abastecimento e das redes de supermercados.

Apesar de reconhecerem que a propriedade da terra que ocupam pertence à Santa Casa de Misericórdia de São Paulo, não reconhecem a legitimidade desse fato legal. Pois a maioria encontra-se na condição de posseiros sem pagar a renda da terra, numa clara demonstração de insubordinação às regras do mesmo mercado capitalista.

O Estudo realizado sobre o bairro de Santo Ângelo, permitiu constatar que o processo de diferenciação social não se realiza de forma homogênea e que, nem sempre, promove a proletarização dos agricultores. Apesar da ocorrência deste processo no bairro estudado, verifica-se, também, a ocorrência do processo de (re) criação camponesa.

Muitos agricultores que foram vitimados pela expropriação, em diversas regiões do campo brasileiro, encontraram na forma da posse a maneira de entrar na terra. A posse abriu, portanto, uma possibilidade de os agricultores conquistarem a autonomia do seu trabalho. Foi por meio dela que os agricultores conseguiram ocupar pequenas áreas no bairro de Santo Ângelo. Alguns deles, numa melhor condição, conseguiram transferir a posse (a luva) a outros agricultores recém-chegados e se instalar como proprietários em outros Distritos, ou como comerciantes de estabelecimentos comerciais no mesmo Distrito.

O Bairro de Santo Ângelo localiza-se no Distrito de Jundiapeba, onde se observa um intenso processo de expansão urbana, sendo um dos mais populosos e o que mais recebeu migrantes nos últimos dez anos no município de Mogi das Cruzes.

A expansão das atividades urbanas, ao engendrar novos costumes e hábitos alimentares em sua população, gera novas demandas de consumo. Os agentes do mercado - atravessadores, comerciantes, distribuidores e redes de supermercados - que atuam na comercialização de produtos frescos, de posse da 
posição de catalisador de novas tendências e produtos, são os que mais tiram vantagens do mercado, por sua situação de intermediários entre os produtores e os consumidores. Essa situação permite que estes agentes atuem no mercado realizando o controle da comercialização e da informação sobre as condições do mercado.

As grandes redes de super e hipermercados, ao serem internacionalizadas, passaram a desenvolver sistemas próprios de abastecimento que se constitui basicamente na instalação de centrais de compra que são responsáveis pela celebração de contratos com os fornecedores (as CDR Centrais de Distribuição Rural) que estabelecem as normas da fiscalização sanitária nas instalações das CDR e da qualidade das mercadorias produzidas. Os contratos estabelecem que as CDR entreguem as mercadorias diretamente nas lojas da rede e a manutenção de promotores diariamente em cada loja. Como as mercadorias são entregues, diariamente, pelas CDR diretamente nas lojas, as redes de super e hipermercados acabaram se livrando dos gastos com os transportes e também escaparam do controle da comercialização realizado pelas grandes centrais de abastecimento.

Foi possível verificar, também, que o processo de expansão urbana em curso representa maiores dificuldades para esses agricultores manterem sua produção agrícola. No caso do município de Mogi das Cruzes, onde há uma grande demanda por preservação e conservação de áreas naturais, esta situação se conjuga com a anterior, tornando ainda mais crítica a reprodução social desses agricultores no bairro.

Enfim, a luta dos agricultores pela terra e o crescimento da demanda urbana de alimentos são faces distintas e contraditórias do mesmo processo. A expansão urbana e o processo de modernização da agricultura, ao serem mediados pela lógica capitalista, têm gerado diferentes processos sociais e têm promovido o (re) encontro dos trabalhadores do campo com a terra, abrindo, pois, uma possibilidade que, se bem aproveitada, poderá se reverter em importantes conquistas sociais. 


\section{Referências Bibliográficas}

ALVES LUENGO, R.F. e HÉLIO JUNQUEIRA, A. Distribuição de Hortaliças no Brasil. Circular Técnica; No 16. Setembro. Divisão de Hortaliças. São Paulo; EMBRAPA. 1999.

ABROMOVAY, R. Paradigmas do Capitalismo Agrário Em Questão. São Paulo. Hucitec/Unicamp. 1992.

AZEVEDO. P. F. e FAULI. E.F. Subsistemas Estritamente Coordenados Baseados em Confiança: O Caso de Verduras. Anais do IV Congresso Internacional de Economia e Gestão de Redes Agroalimentar. São Paulo. 2003.

BATALHA, J. R. Calhaus e Burgaus. Coleção Boigyana; No 1, São Paulo. Edição fac-símile da Prefeitura Municipal de Mogi das Cruzes. 2001.

BELIK. W. Mecanismos de Coordenação na Distribuição de Alimentos no Brasil. São Paulo. Campinas. IE/UNICAMP. 2000. Páginas 131 a 159.

BOMBARDI, L. M. O Papel da Geografia Agrária no Debate Teórico sobre os Conceitos de Campesinato e Agricultura Familiar. Revista GEOUSP. N ${ }^{\circ}$ 14. São Paulo. 2003.

O Bairro Rural como Identidade Territorial: a Especidade da Abordagem do Campesina na Geografia. São Paulo. Revista Agrária; No I. 2004, páginas 55 a 95.

CÂNDIDO. A. Os Parceiros do Rio Bonito. São Paulo. Livraria Duas Cidades. 1971.

CARVALHO. J. C. M. Camponeses no Brasil. Petrópolis. Editora Vozes. 1978.

CHABARIBERY, D. Inovação e Desigualdade no Desenvolvimento da Agricultura Paulista. Coleção Estudos Agrícolas. São Paulo. Instituto de Economia Agrícola 1999.

CHAYANOV, A. La Organización de La Unidade Económica Campesina. Buenos Aires. Ediciones Nueva Visión. 1974.

COMPANHIA DE ENTREPOSTOS E ARMAZÉNS GERAIS DE SÃO PAULO. Diversos Dados. Seção de Economia e Desenvolvimento. São Paulo. 2005.

DE LA CORTE, J. Contribuição ao Estudo do Abastecimento de São Paulo em Produtos Hotifrutícolas. São Paulo. Instituto de Geografia da Universidade de São Paulo. Série Teses e Monografias. № 31. 1985.

DIAS, M. M. A Formação das Elites numa Vila Colonial Paulista: Mogi das Cruzes (1608-1646). Tese de Mestrado. FFLCH da USP. São Paulo. 2001.

FARINA et all. Regulamentação Governamental e Estratégias de Negócio no Mercado Brasileiro de Frutas e Legumes Frescos. Campinas. IE/UNICAMP. 2000. Páginas 161 a 181. 
FREIRE. M. Histórias da História de Mogi das Cruzes. Coleção Boigyana; № 2. São Paulo. Edição fac-símile da Prefeitura Municipal de Mogi das Cruzes. 2002.

FURTADO, C. Formação Econômica do Brasil. $27^{a}$ Edição. São Paulo. Companhia Editora Nacional. 1998.

GRAZIANO DA SILVA, J. A Nova Dinâmica da Agricultura Brasileira. Campinas. Ed. Unicamp. 1998.

GREEN. R. e SCHALLER, B. Logística e Racionalização Comercial na Área dos Produtos Alimentares Frescos. Campinas. IE/UNICAMP. 2000. Páginas 107 a 130. GRÍNBERG, I. História de Mogi das Cruzes: Do Começo até 1954. $2^{\text {a }}$ tiragem. São Paulo. (produção autônoma). 1961. autônoma). 1995.

Mogi das Cruzes de Antigamente. São Paulo. (produção

GUERRA, A. T. Dicionário Geológico-Geomorfológico. 4ª Edição. $2^{\mathrm{a}}$ Tiragem. Rio de Janeiro. IBGE. 1975.

GUIMARÃES, A. P. Quatro Séculos de Latifúndio. $6^{\mathrm{a}}$. Rio de Janeiro. Editora Paz e Terra. 1989.

HÉLIO JUNQUEIRA. A. e ALVES LUENGO, R.F. Mercados Diferenciados de Hortaliças. Circular Técnica. No 17, Outubro. Divisão de Hortaliças. São Paulo. EMBRAPA. 1999.

INSTITUTO BRASILEIRO DE GEOGRAFIA E ESTATÍSTICA. Censos Demográficos de 1991 e 2000. , Censo Agropecuário 1995-2000.

KAUTSKY, K. A Questão Agrária. Rio de Janeiro. Editora. Laemmert. 1968.

LÊNIN, V.I. O Desenvolvimento do Capitalismo na Rússia. Série: Os Economistas. Capítulo II. São Paulo. Editora Nova Cultural. 1985.

MARQUES, M. I. M. O Modo de Vida Camponês Sertanejo e sua Territorialidade no Tempo das Grandes Fazendas e nos dias de Hoje em Ribeira-PB. Tese de Mestrado. São Paulo. FFLCH/USP. 1994.

O Conceito de Espaço Rural em Questão. São Paulo. Revista Terra Livre. Ano 18; № 19. 2002. Páginas 95-112. 2002.

, A Atualidade do Uso do Conceito de Camponês. João Pessoa. Anais do XIII Encontro Nacional de Geógrafos. 2002.

, A Questão Agrária Hoje e os Desafios do Governo Lula. São Paulo. Revista Agrária; No 1. 2004. Páginas 37 a 54.

MARTINS, J.S. O Cativeiro da Terra. São Paulo. Hucitec. 1996.

, A Questão Agrária Brasileira e o Papel do MST in A Reforma Agrária e a Luta do MST. Petrópolis. Editora Vozes. 1997. 
MARX, K. O Capital. Livro 1. Volume I. Capitulo IV. Rio de Janeiro. Editora Civilização Brasileira. 1980.

O Capital. Livro 3. Volume 5. Capítulo XLVII. $3^{a}$ edição. Rio de Janeiro. Editora Civilização Brasileira. 1981.

MAURO O. e MARQUES. P. V. Estudo de caso: Empresa Da Roça - Uma Análise do Complexo Agroindustrial para Hortaliças Minimamente Processadas. Anais do XXXIX Congresso Brasileiro de Economia e Sociologia Rural. 2001.

MENDRAS, H. Sociedades Camponesas. Rio de janeiro. Zahar Editores. 1978.

MOGI NEWS. Chavedar Fala de Desenvolvimento. $2^{\circ}$ Caderno. Ano 26; Edição 3615. Mogi das Cruzes. 2005. Página 1.

OLIVEIRA, A. U. A Geografia das Lutas no Campo. São Paulo. Editora Contexto. 1988.

Ática. 1990. , Modo Capitalista de Produção e Agricultura. São Paulo. Editora Agricultura e Indústria no Brasil. $N^{\circ}$ 58. Boletim Paulista de Geografia. São Paulo. AGB. 1981.

, O Campo Brasileiro no Final dos Anos 80. Boletim Paulista de

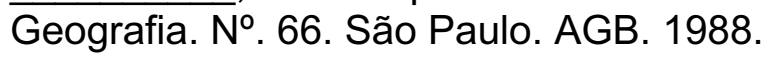

, Renda Capitalista da Terra Diferencial, Absoluta e de Monopólio e Preço da Terra. Revista Orientação. Nos. 6 e 7. São Paulo. IGESOG/DG/USP. 1985/86.

1991.

, Agricultura Camponesa no Brasil. São Paulo. Editora Contexto. SPM/CEM. 1994.

Agricultura Brasileira - As Transformações Recentes. São Paulo.

, O Campo Brasileiro no Final dos Anos 80. In A Questão Agrária Hoje. STÉDILE et all. (Organizador). Porto Alegre. Editora da Universidade Federal do Rio Grande do Sul/Associação Nacional de Cooperação Agrícola. 1994.

A Longa marcha do campesinato brasileiro: movimentos sociais, conflitos e Reforma Agrária in Dossiê Desenvolvimento Rural. São Paulo. Estudos Avançados 15 (43). USP. 2001.

PREFEITURA MUNICIPAL DE MOGI DAS CRUZES. Lei Orgânica. Mogi das Cruzes. 2005.

PRADO JÚNIOR, C. Evolução política do Brasil e Outros Estudos. A cidade de São Paulo e Contribuição para a Geografia urbana da cidade de São Paulo. São Paulo. Editora Brasiliense. 3ª edição. Capítulos V e VI. 1961.

QUEIROZ, M.I.P. Bairros Rurais Paulistas. São Paulo. Editora Livraria Duas Cidades. 1973. 
SAAB. W. G. L. Supermercados no Brasil: O Movimento das Grandes Empresas. Boletim No 2. Setembro. São Paulo. EMBRABA. 2000.

SANTOS, J. V. T. dos. Colonos do Vinho. São Paulo. Edidota Hucitec. 1978.

SANTOS. R.C. As Infrações Ambientais e sua Fiscalização no Município de Mogi das Cruzes - São Paulo. Tese de Mestrado. FFLCH - Departamento de Geografia da USP. São Paulo. 2001.

SEABRA, M. G. As Cooperativas Mistas do Estado de São Paulo. Série Teses e Monografias. São Paulo. Instituto de Geografia da Universidade de São Paulo. No 30. 1977.

Vargem Grande: Organização e Transformações de um Setor do Cinturão-Verde Paulistano. Série Teses e Monografias No 4. São Paulo. Instituto de Geografia da Universidade de São Paulo. 1971.

SHANIN, T. A Definição de Camponês: Conceitualização e Desconceitualização. São Paulo. In Estudos CEBRAP. № 26. 1980.

SILVA. M. A. M. A Luta pela Terra. São Paulo. Editora UNESP. 2004.

SINDICATO RURAL DE MOGI DAS CRUZES. Perfil da Agricultura em Mogi das Cruzes. Mogi das Cruzes. 1997.

STÉDILE, J. P. (Coordenador). A Questão Agrária Hoje. $3^{a}$ Edição. Porto Alegre. Editora da Universidade Federal do Rio Grande do Sul/Associação Nacional de Cooperação Agrícola. 1994.

(Organizador). A Questão Agrária Hoje. $3^{a}$ Edição. Porto Alegre. Editora da Universidade do Rio Grande do Sul/Associação Nacional de Cooperação Agrícola. 1994.

TATIANE. C. et all. O Cinturão Verde no Município de Mogi das Cruzes - SP. Trabalho Acadêmico de Iniciação Científica. Presidente Prudente. UNESP. 2004.

TOMOO. H. O Imigrante Japonês: História de sua Vida no Brasil. São Paulo. Centro de Estudos Nipo-Brasileiro. 1987. Páginas 201 a 208.

VALVERDE, Orlando. Metodologia da Geografia Agrária. In Geografia Agrária do Brasil. Rio de Janeiro. CBPE/INEP/MEC. 1964.

WOORTMANN. K. Com Parente Não se Neguceia: O Campesinato Como Ordem Moral. Anuário Antropológico. Brasília. Editora da UnB. 1990.

ZYLBERSTAJN. D. et all. Sacolões Como Alternativa à Distribuição de Hortifrutigranjeiros em São Paulo. Anais do II Seminário em Administração. $N^{\circ} 2$, páginas 355 a 368. São Paulo. Faculdade de Economia e Administração da USP. 1997.

Abastecimento de Grandes Conglomerados Urbanos e a Privatização do CEAGESP. Anais do II Seminário em Administração; $n^{\circ} 2$, páginas 374 a 387. São Paulo. Faculdade de Economia e Administração da USP. 1997. 


\section{Fotografias}

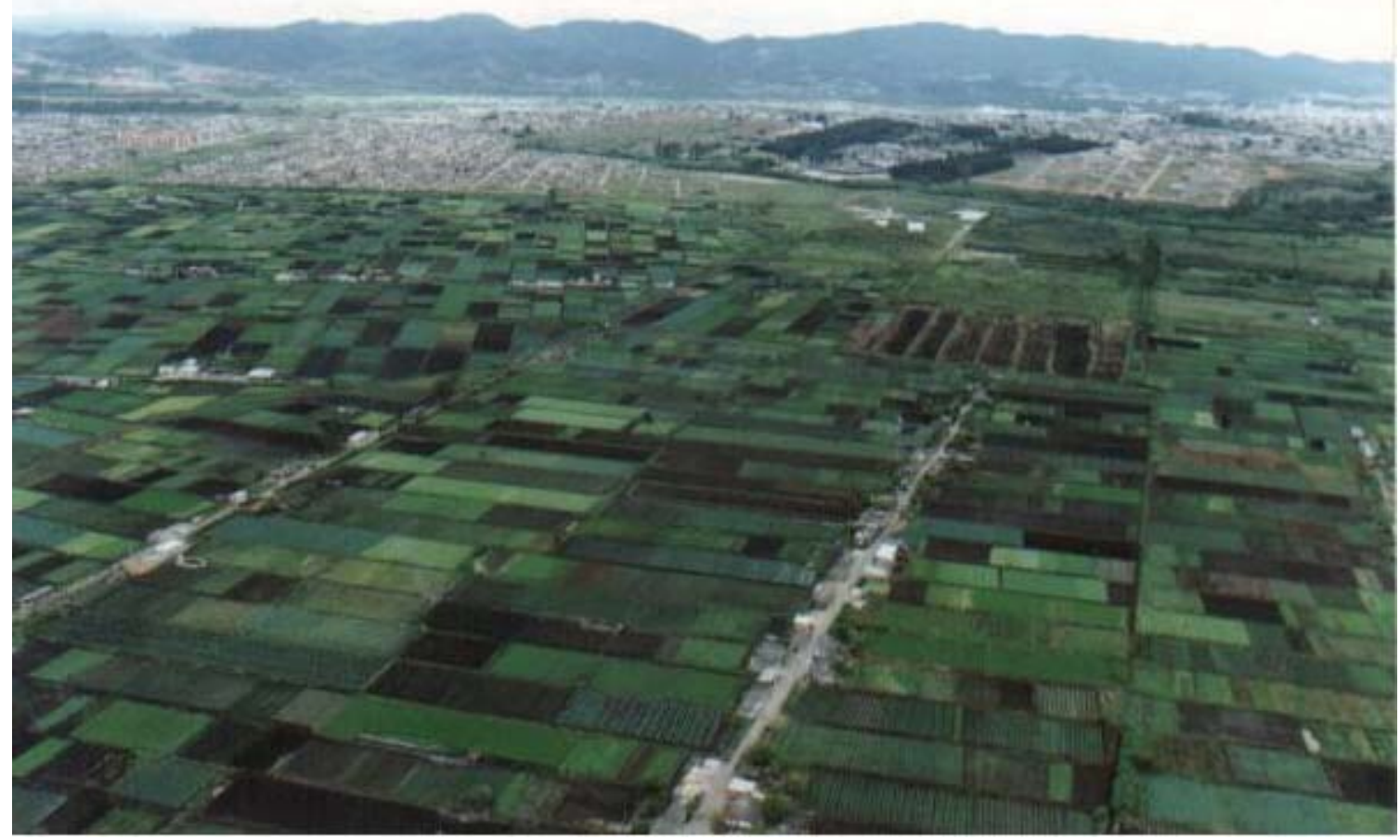

Número 1. Vista área do bairro de Santo Ângelo (fornecida pelo senhor TAKASHI - ano 2000)

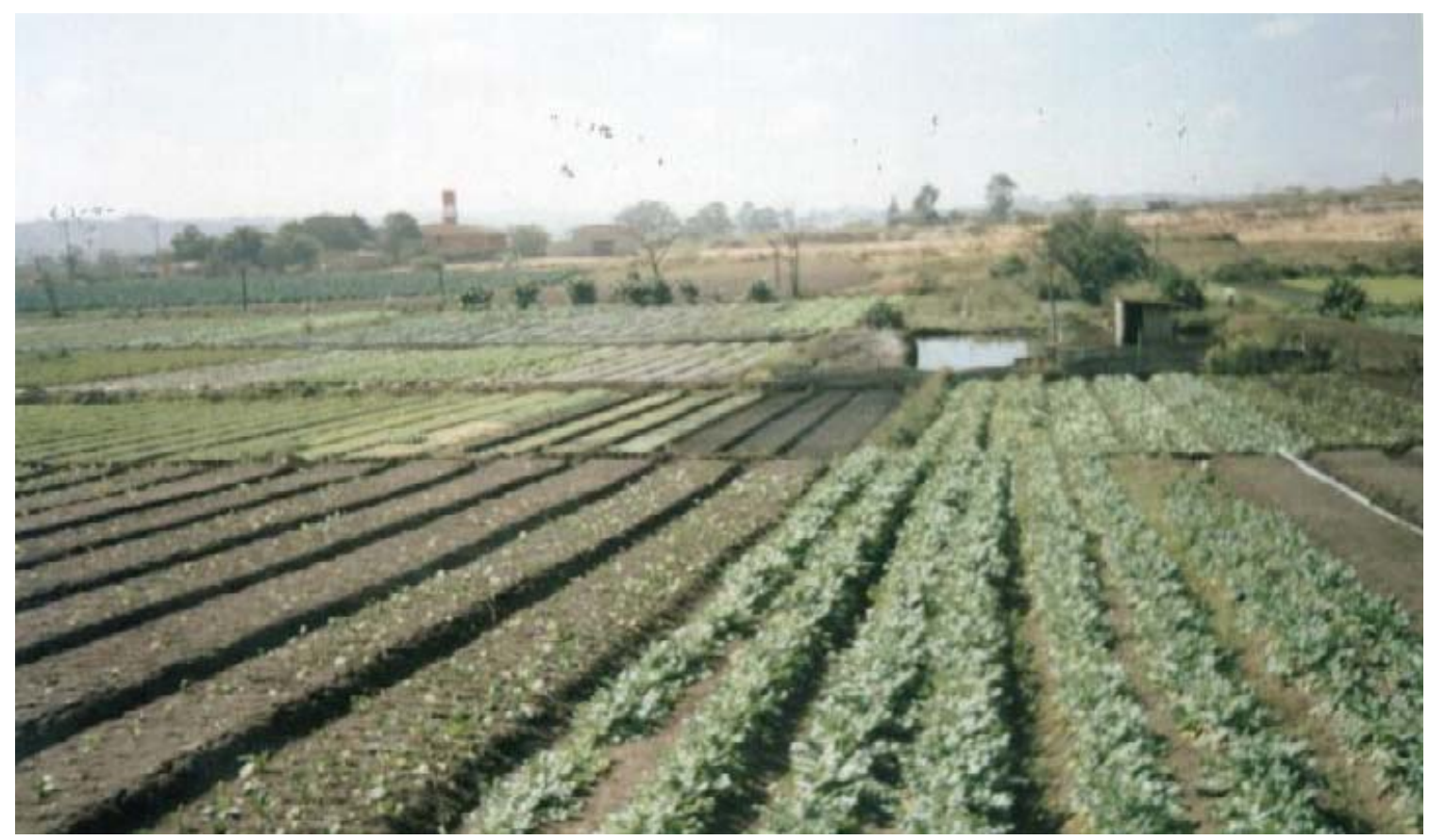

Número 2. Vista das quadras de uma UPF. Fotografia de Antônio Carlos da Paz Santana - Julho/2003. 


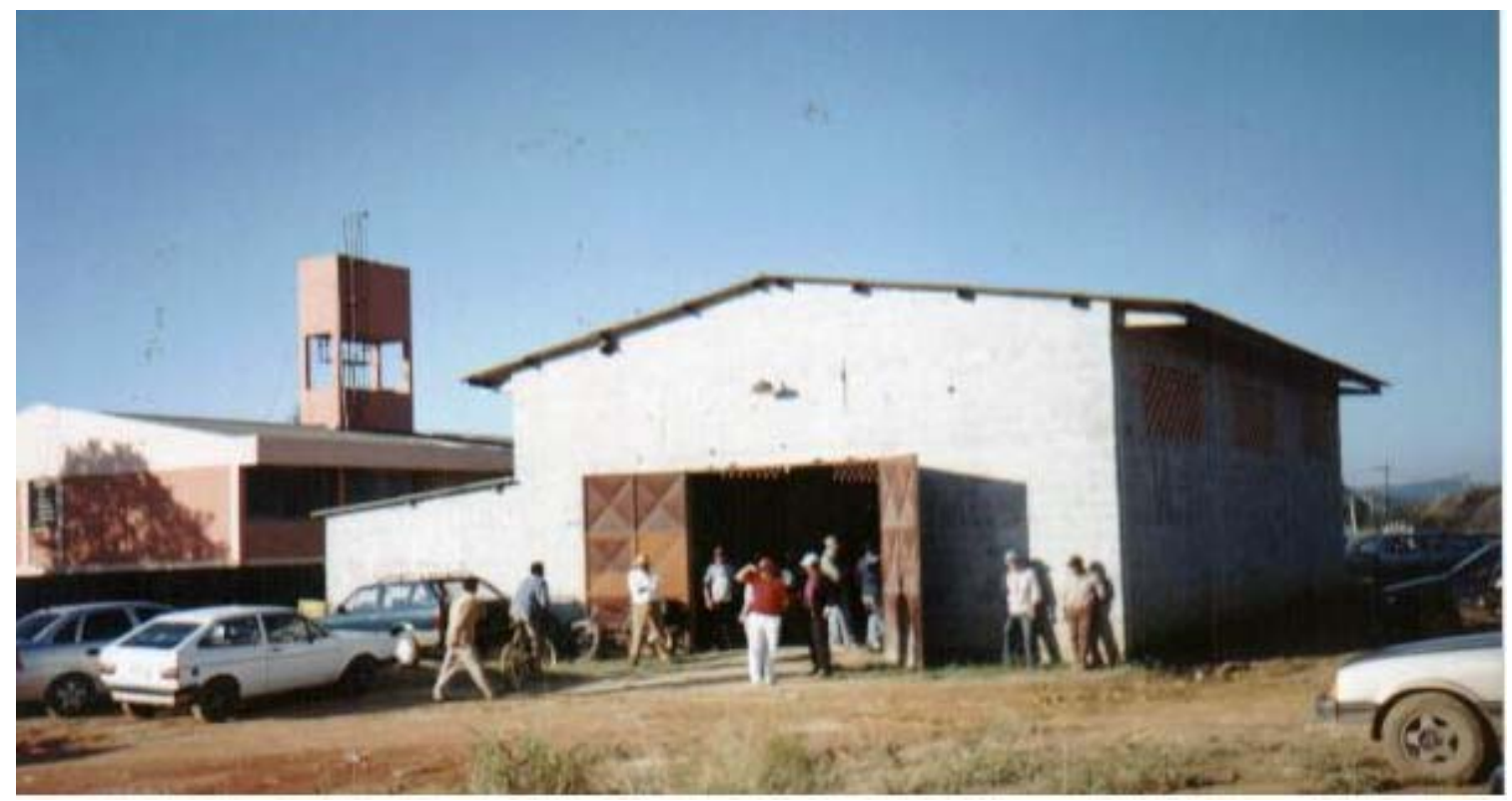

Número 3. Vista externa do barracão onde funciona a sede da Associação dos Chacareiros de Mogi das Cruzes. Fotografia de Antônio Carlos da Paz Santana - Agosto de 2003.

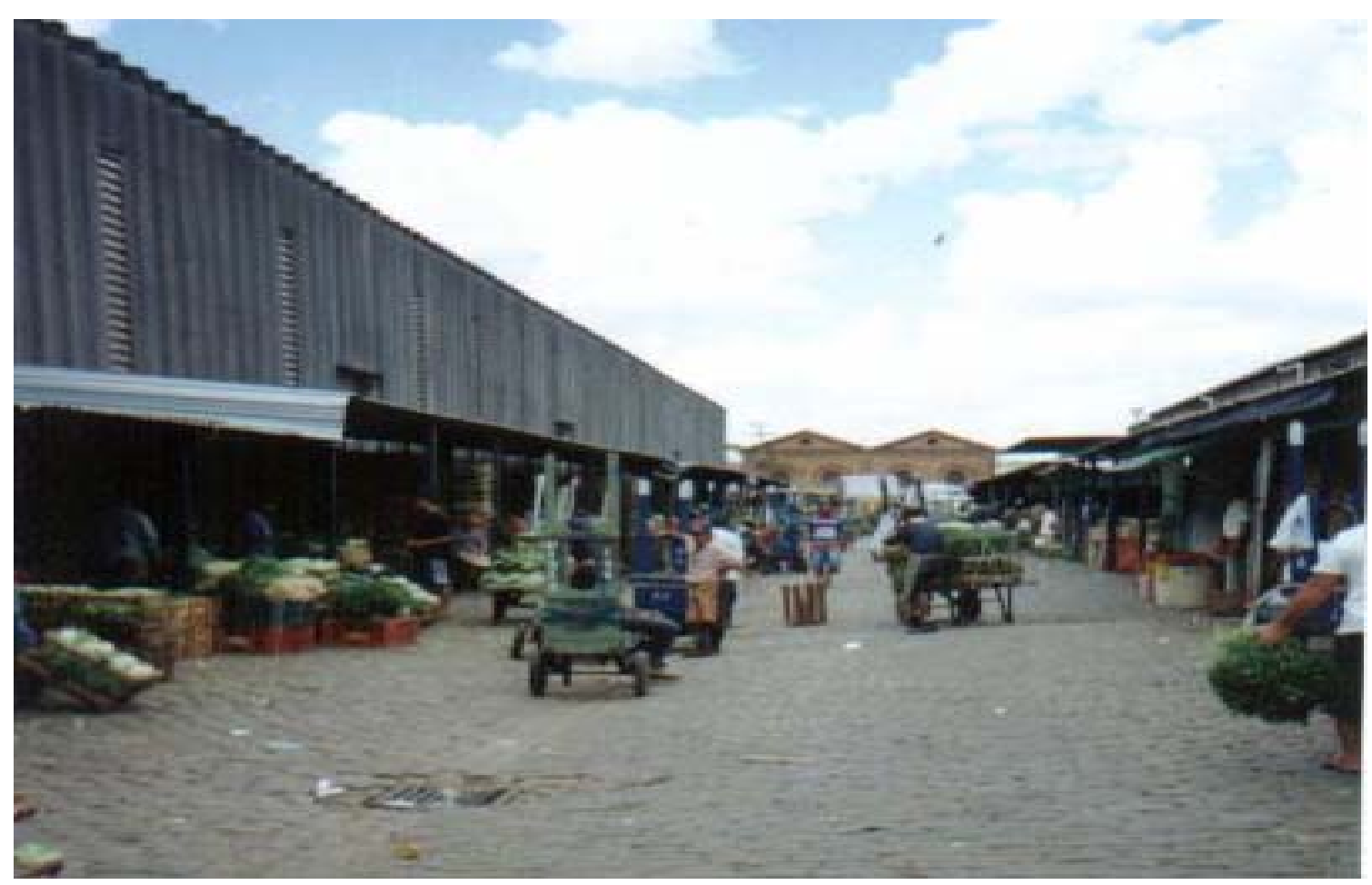

Número 4. Vista interna da CEAAP. Fotografia de Antônio Carlos da Paz Santana - Novembro de 2004. 


\section{ÍNDICE DE TABELAS}

1. Classificação dos Tipos, Segundo o Processo Social .....................................53

2. População do Distrito de jundiapeba - 1991/2000 .........................................55

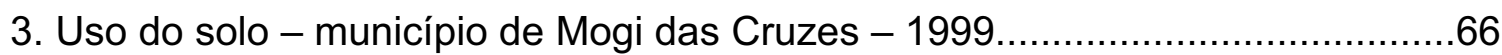

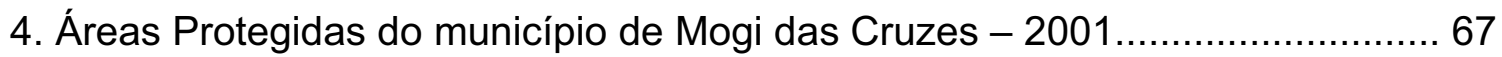

5. Área territorial, distância da capital e porcentagem da área de proteção aos mananciais por municípios do Alto Tietê...............................6 69

6. Principais Produtos cultivados durante os meses de julho, agosto e setembro de 2004.

7. Áreas Produtoras, Produtos e Mercados da Produção de Mogi das Cruzes em 2005

8. Procedência das Hortaliças comercializadas na CEAGESP durante o ano de 2004

9. Produção por município segundo os Escritórios de Desenvolvimento Rural de Mogi das Cruzes, Sorocaba e São Paulo para o ano de 2004

10. Horário de comercialização de verduras, legumes, frutas e flores no Entreposto da cidade de São Paulo - 2005.

11. Destino dos hortifrutigranjeiros comercializados na CEAGESP em São Paulo em 1983 e 1993

12. Distribuição dos sacolões na cidade de São Paulo segundo as zonas urbanas em 2006.

13. Rede Carrefour 158

14. Rede Extra 159

15. Rede MAKRO 159

16. Estudo sobre a Evolução das Empresas de auto-Serviços 161

17. Origem do Capital das Maiores Empresas 163 


\section{ÍNDICE DE MAPAS/ESQUEMAS}

1. Mapa do interior do bairro rural de Santo Ângelo........................................ 57

2. Mapa da localização do bairro de Santo Ângelo no Distrito de Jundiapeba.......72

3. Morfologia agrária das UPF de santo Ângelo................................................ 80

4. Mapa da Grande são Paulo: localização do município de Mogi das Cruzes....104

5. Esboço da organização do mercado de hortaliças..................................... 170 